$$
\begin{aligned}
& \text { UNIVERSIDADE DE SÃO PAULO } \\
& \text { INSTITUTO DE GEOCIÊNCIAS }
\end{aligned}
$$

\title{
EVOLUÇÃO ESTRUTURAL DA SIERRA DE UMANGO, SIERRAS PAMPEANAS OCIDENTAIS, NOROESTE DA ARGENTINA
}

\author{
Vinícius Tieppo Meira
}

Orientador: Prof. Dr. Mário da Costa Campos Neto

$$
\text { DISSERTAÇÃO DE MESTRADO }
$$

Programa de Pós-Graduação em Geoquímica e Geotectônica

SÃO PAULO 
Autorizo a reprodução e divulgação total ou parcial deste trabalho, por qualquer meio convencional ou eletrônico, para fins de estudo e pesquisa, desde que citada a fonte.

MEIRA, V.T., 2010. Evolução estrutural da Sierra de Umango, Sierras Pampeanas Ocidentais, Noroeste da Argentina. 105 p. Dissertação (Mestrado) - Instituto de Geociências, Universidade de São Paulo, São Paulo. 
Para Thaís,

minha esposa

e doce companheira. 


\section{AGRADECIMENTOS}

Agradeço imensamente a minha família querida, principalmente meus pais (Nelson e Cláudia), irmãos (José Ricardo, Thays, Janaína, Yara e Victor), tios (principalmente Carla, Caio e Tony) e avós (Vera, Cláudio, Graça e Nelson) por todo apoio, carinho e amor concedido ao longo de todo esse trajeto.

Não poderiam faltar meus honrosos agradecimentos à minha mais nova família, Arquimedes, Rita e Thales, pela ajuda indispensável a toda hora.

Meus sinceros agradecimentos ao Prof. Dr. Mário da Costa Campos Neto, por todos esses anos de trabalhos conjuntos, aprendizado e amizade.

Agradeço ainda aos professores Dr. Ricardo Varela, Dr. Pablo Diego González e Dr. Miguel Ângelo Stipp Basei pelos memoráveis dias de campo na bela região da Sierra de Umango e Pré-Cordilheira. Meu agradecimento especial ao companheiro de campo Marcial e família.

Muito obrigado ao amigo e "ex-chefe", geólogo Rafael Bittencourt que, nos tempos em Carajás-PA, permitiu algumas "escapadas" para o amadurecimento das idéias sobre Umango.

Em especial, agradeço aos funcionários do Instituto de Geociências, parte essencial para o desenvolvimento de nossas pesquisas. Meu muito obrigado para a turma da Gráfica, Laminação, Portaria, Audiovisual, Garagem, Laboratório de Optica e Manutenção (sem vocês este trabalho não seria realidade).

Gostaria de agradecer os meus amigos do peito, "geóliguis" e pirajuenses, que contribuíram direta ou indiretamente com esta dissertação.

Por fim, agradeço enormemente à minha esposa e companheira Thaís, pela ajuda na confecção e revisão deste manuscrito, apoio constante e por estar ao meu lado pro que der e vier.

Valeu galera! 
"UM PASSO À FRENTE, E VOCÊ NÃO ESTÁ MAIS NO MESMO LUGAR."

Chico-Science 


\section{RESUMO}

MEIRA, V.T., 2010. Evolução estrutural da Sierra de Umango, Sierras Pampeanas Ocidentais, Noroeste da Argentina. 105 p. Dissertação (Mestrado) - Instituto de Geociências, Universidade de São Paulo, São Paulo.

A Sierra de Umango está localizada na porção ocidental da Província de La Rioja, no noroeste argentino. Situa-se na região do "Pampean Flat-slab" dos Andes Centrais e conforma um conjunto de blocos do embasamento, soerguidos e rotacionados no Cenozóico, denominado de Sierras Pampeanas Ocidentais. As Sierras Pampeanas Ocidentais são caracterizadas por rochas meta-ígneas de idade mesoproterozóica grenvilliana e unidades metassedimentares metamorfisadas no Ordoviciano, e são interpretadas como parte do Terreno Composto Cuyania. As rochas metamórficas da região de Umango são limitadas a oeste por rochas sedimentares devonianas da Pré-Cordilheira, e a leste por rochas ígneas e sedimentares do Sistema Famatina. A descrição litológica e a análise estrutural das rochas da Sierra de Umango possibilitaram propor um modelo de evolução estrutural para a região. Seis unidades geológicas foram diferenciadas: i- unidade do embasamento de idade mesoproterozóica, Ortognaisses Juchi, ii- Unidades Metassedimentares Tambillo e iii- Tambillito, iv- Granito El Peñon, Ordoviciano sincolisional, v- Unidade de Rochas Metabásicas El Cordobés, vi- granitos tardi a póscolisionais Los Guandacolinos e Cerro Veladero. No evento tectônico colisional Ordoviciano, caracterizado por um sistema de nappes e zonas de cisalhamento, foram reconhecidas três fases deformacionais (D1, D2 e D3). A fase D1 corresponde provavelmente ao estágio do metamorfismo progressivo, D2 apresenta condições P-T próximas ao pico metamórfico e a fase D3, de dobras apertadas a recumbentes com foliação plano-axial S3, freqüentemente associada a falhas inversas, registra o estágio retrogressivo do metamorfismo. A estrutura metamórfica principal das rochas é uma foliação de transposição S2, ou uma foliação milonítica. Relíquias de foliação S1 são reconhecidas, principalmente, em núcleos de porfiroblastos intercinemáticos de granada e estaurolita, sugerindo a progressão contínua das fases D1 e D2. O metamorfismo ordoviciano alcançou condições de fácies anfibolito superior a granulito em regimes de média a alta pressão. A estrutura está caracterizada por klippen dos Ortognaisses Juchi sobre a Unidade Tambillo, transportadas para S-SW e limitada, a oeste, por uma zona de cisalhamento lateral dextral (Zona de Cisalhamento Cerro Cacho - Puntilla), como rampa lateral. Esse quadro estrutural está relacionado à colisão oblíqua do Terreno Cuyania, subductado sob a protomargem de Gondwana. O 
sentido de subducção para NE foi inferido com base na cinemática de extrusão sinmetamórfica, registrada nas nappes (topo para S-SW) e na Zona de Cisalhamento Cerro Cacho - Puntilla. Pelo menos dois eventos posteriores deformaram as estruturas pré-existentes. A fase deformacional D4 corresponde a um dobramento normal, com comprimento de onda na ordem de $10 \mathrm{~km}$, orientado N-S. São dobras cilíndricas que deformaram a foliação S2 e associam-se a zonas de cisalhamento discretas. O padrão cilíndrico e os eixos subhorizontais das dobras D4 pressupõem a orientação horizontal a subhorizontal para as estruturas pré-existentes, principalmente S2. As dobras D4 são responsáveis pela preservação sinformal das klippen Juchi e Água La Falda. A foliação, em estado sólido, presente no Granito Los Guaundacolinos é paralela ao plano axial destas dobras. Essa deformação corresponde à tectônica Chanica, na interface entre o Devoniano e o Carbonífero. Dobras D5, de eixo com orientação E-W, deformam o conjunto das estruturas e podem estar vinculadas ao soerguimento durante o Ciclo Andino.

Palavras-chave: Gondwana Ocidental; Andes Centrais; Terreno Cuyania; PréCordilheira; Ciclo Famatiniano; Ciclo Andino; Umango; Análise Estrutural 


\section{ABSTRACT}

MEIRA, V.T., 2010. Structural Evolution of the Sierra de Umango, Western Sierras Pampeanas, Northwestern Argentina. 105 p. Dissertation (Master) - Geosciences Institute, University of São Paulo, São Paulo.

The Sierra de Umango is located at the occidental portion of La Rioja Province, northwestern Argentina. It is part of basement blocks, uplifted and rotated in the Cenozoic times, called Western Sierras Pampeanas. This region is situated in the Pampean Flat-slab of the Central Andes. Meta-igneous rocks of grenvillian mesoproterozoic age and metasedimentary units metamorphosed in the Ordovician times, characterize the Western Sierras Pampeanas. These rocks are interpreted as a part of Cuyania Composite Terrane. In the region of the Sierra de Umango, the Western Sierras Pampeanas are limited on the west by Devonian sedimentary rocks of Precordillera, and by igneous and sedimentary rocks of Famatina System on the east. The lithological description and structural analysis of rocks from Sierra de Umango enable to propose a structural evolution model for the region. Six geological units were distinguished: $i$ - the basement unit Juchi Ortogneisses of mesoproterozoic age, iimetasedimentary units Tambillo and iii- Tambillito, iv- Ordovician sin-collisional El Peñon Granite, v- El Cordobés metamafic rocks unit; vi- late to post-collisional Los Guandacolinos and Cerro Veladero granites. The Ordovician collisional event is characterized by a nappe system and shear zones, and the rocks affected by this event show three deformational phases (D1, D2 and D3). D1 phase corresponds probably to the progressive metamorphic stage; $D 2$ exhibits $P-T$ conditions close to metamorphic peak; and D3 phase, of tight to recumbent folds with S3 axial plane foliation which is often related to thrust faults, records the retrogressive metamorphic stage. The main metamorphic structure of Umango's rocks is a transposition foliation S2 or a mylonitic foliation. The relics of $S 1$ are recognized, mainly, in cores of interkinematics porphyroblasts of garnet and staurolite, suggesting a continuous progression from D1 to $D 2$. The Ordovician metamorphism reached granulite to upper amphibolite facies conditions in a medium to high pressure regime. The general structure is characterized by Juchi Ortogneisses klippen which was overthrust onto Tambillo Unit, in a S-SW sense, and it is limited, on west, by a right lateral shear zone (Cerro Cacho - Puntilla Shear Zone), as a lateral ramp. This structural pattern is related to the oblique collision of Cuyania Terrane, subducted underneath to the proto-Andean margin of Gondwana. The subduction sense to NE was inferred from the sin-metamorphic extrusion, registered on the nappes (top to S-SW) and on the Cerro Cacho - Puntilla Shear Zone. 
At least two latest events deformed the earlier structures. The D4 deformacional phase corresponds to a normal folding, with wavelenght at about $10 \mathrm{~km}$, with $\mathrm{N}-\mathrm{S}$ orientation. They are cylindrical folds which modified de S2 surface and are associated to discrete shear zones. The cylindrical pattern and the subhorizontal axes of the D4 folds presuppose that S2 were, originally, flat-lying surfaces. D4 folds are responsible for preserving the sinformal Juchi and Água La Falda klippen. The solid state foliation described in the Los Guandacolinos Granite is parallel to the D4 axial planes. This deformation corresponds to the Chanica Tectonic, on the interval between Devonian and Carboniferous times. D5 folds, with E-W oriented axes, deform the structures set and could be associated with the uplifting during the Andean Cycle.

Keywords: Western Gondwana; Central Andes; Cuyania Terrane; Precordillera; Famatinian Cycle; Andean Cycle; Umango; Structural Analysis 


\section{Lista de Figuras}

Figura 1: Relações tectônicas no Paleozóico Inferior entre a protomargem Andina de Gondwana e o Terreno acrescionário Cuyania (Modificado de Sato et al., 2004)......16 Figura 2: Mapa geológico regional em escala 1:500.000, baseado em Kilmurray \& Dalla Salda (1971), Casquet et al. (2008a), Caminos \& Fauqué (1999) e Fauqué et al. (2004), com indicação das cidades e locais para acampamento e repouso ("puestos") na Sierra de Umango e proximidades 18

Figura 3: Principais segmentos da Cordilheira Andina e os mais importantes processos envolvidos durante a formação de cada um deles (Modificado de Ramos \& Aleman, 2000) 22

Figuras 4 a, b, c: Modelo de evolução geotectônica dos Andes Centrais durante o Ciclo Famatiniano (Modificado de Quernadelle \& Ramos, 1999). .28

Figura 5: Seção transversal dos Andes Centrais na latitude 2900"S (Modificado de Ramos et al., 2002)...... 31

Figura 6: Modelo digital de terreno com a localização geográfica e divisão da PréCordilheira Argentina. Escala de cores corresponde à cota topográfica. 32

Figura 7: Mapas paleogeográficos do Gondwana Ocidental, com crátons, bacias intracratônicas e orógenos identificados: a) Cambriano Inferior - Microcontinente hipotético SAFRAN situado entre América do Sul, África e Antarctica; b) Cambriano Superior-Ordoviciano - Terreno Precordilheira começa a percorrer, por forças transpressivas, a borda continental; c) Devoniano - Terreno Precordilheira é empurrado contra o continente pela rotação da movimentação da placa Proto-Pacífica (Modificado de Acenõlanza et al., 2002)...... 36

Figura 8: Mapa Geológico da Sierra de Umango, escala 1:250.000.

Figura 9: Mapas e seções geológicas em escala 1:100.000 - a) Seção Geológica Água La Falda; b) Seção Geológica Cerro Cacho - Rio Umango. .73

Figura 10: Mapas e seções geológicas em escala 1:100.000 - a) Seção Geológica Los Guandacolinos; b) Seção Geológica Barreal Chico - Puesto Tambillito..... 78

Figura 11: Mapa e seção geológica em escala 1:100.000 - Seção Geológica Cerro Puntilla - Quebrada La Champa. .83 


\section{Lista de Tabelas}

Tabela 1: Províncias Geológicas dos Andes Centrais e Ciclos Orogênicos (Modificado de Ramos, 1988b). 24

Tabela 2: Representação esquemática dos eventos geológicos principais reconhecidos na história Paleozóica da Protomargem de Gondwana, com a comparação entre os eventos ocorridos no Terreno alóctone Pré-Cordilheira e o antepaís Gondwânico (Sierras Pampeanas) (Modificado de Pankhurst \& Rapela, 1998). 30

\section{Lista de Pranchas Fotográficas}

Prancha II




\section{Lista de Abreviaturas}

\begin{tabular}{|c|c|}
\hline N - norte; & NE - nordeste; \\
S - sul; & NW - noroeste; \\
E - leste; & SE - sudeste; \\
W - oeste; & SW - sudoeste; \\
\hline NNE - norte-nordeste; & ENE - leste-nordeste; \\
NNW - norte-noroeste; & ESE - leste-sudeste; \\
SSE - sul-sudeste; & WNW - oeste-noroeste; \\
SSW - sul-sudoeste; & WSW - oeste-sudoeste; \\
\hline AMCG - complexo ígneo plutônico & ZCCP - Zona de Cisalhamento Cerro \\
composto por Anortosito, Mangerito, & Cacho - Puntilla \\
Charnockito e Granito; & \\
\hline
\end{tabular}

Abreviações dos minerais utilizadas nas pranchas de fotografias (fotomicrografias): Qtz - quartzo, PI - plagioclásio, FK - fedspato potássico, Hbl - hornblenda, Cpx clinopiroxênio, Amph - anfibólio, Car - carbonato, Ttn - titanita, Rt - rutilo, Ky - cianita, Sil - sillimanita, St - estaurolita, Chl - clorita, Ms - muscovita, Bt - biotita e Grt granada. 


\section{SUMÁRIO}

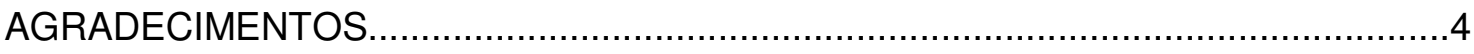

RESUMO

ABSTRACT

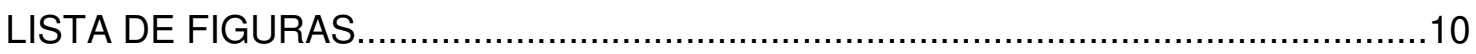

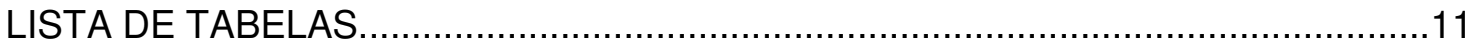

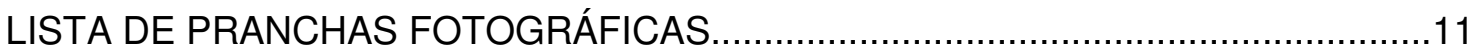

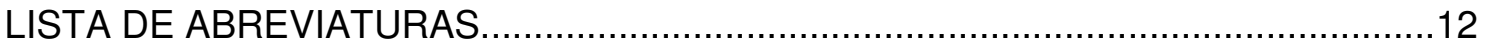

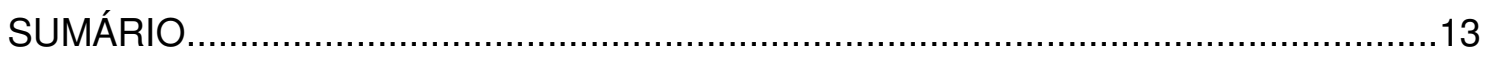

1.

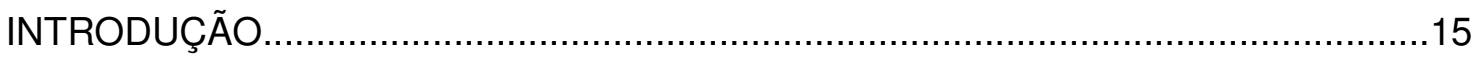

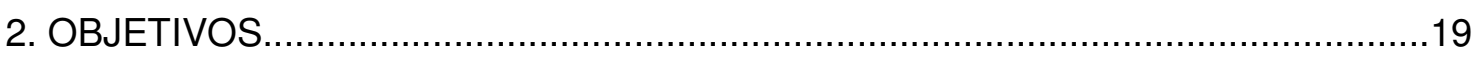

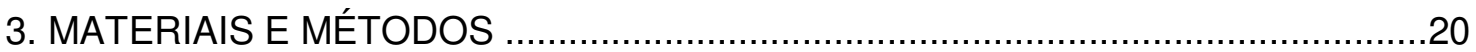

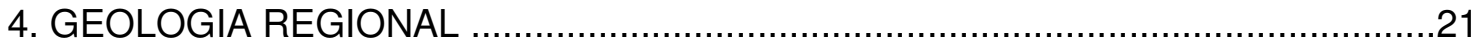

4.1. Andes Centrais - Contextualização e Interpretações Geotectônicas ...........21

4.2. Precordilheira Argentina - Interpretações Geotectônicas.............................31

4.3. Evolução do conhecimento geológico das Sierras Pampeanas Ocidentais e

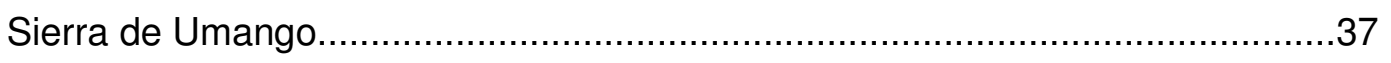

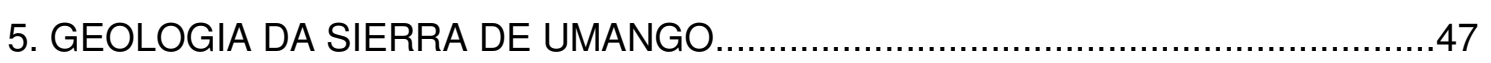

5.1. Unidades Litoestratigráficas e Tectônicas................................................47

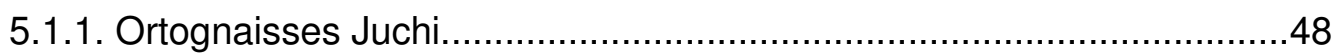

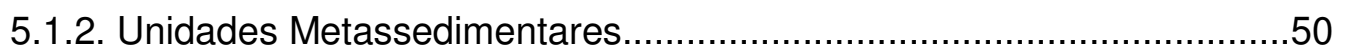

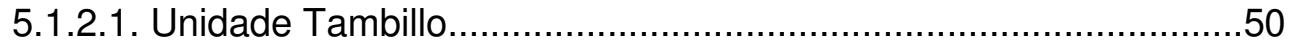

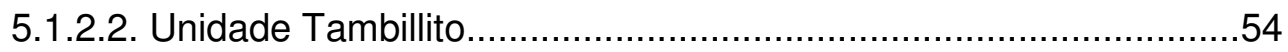

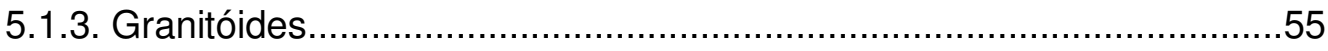

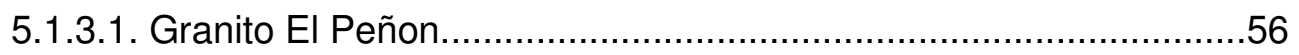

5.1.3.2. Granitos Los Guandacolinos e Cerro Veladero...........................61

5.1.4. Unidade de Rochas Metabásicas El Cordobés.................................61

5.1.5. Seqüência Carbonática La Troya......................................................63

5.1.6. Coberturas Sedimentares...................................................................63

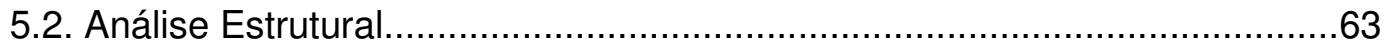

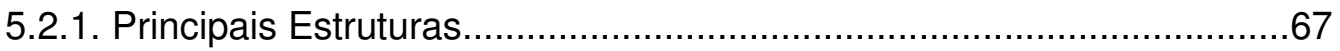

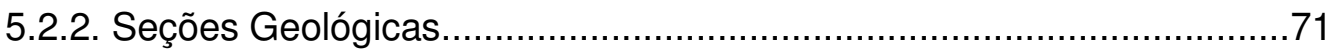

5.2.2.1. Seção Geológica Água La Falda...............................................71

5.2.2.2. Seção Geológica Cerro Cacho - Rio Umango.............................72 
5.2.2.3. Seção Geológica Los Guandacolinos

5.2.2.4. Seção Geológica Barreal Chico - Puesto Tambillito.......................77

5.2.2.5. Seção Geológica Cerro Puntilla - Quebrada La Champa..............79

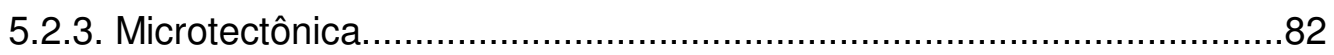

6. DISCUSSÃO

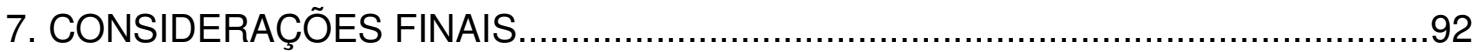

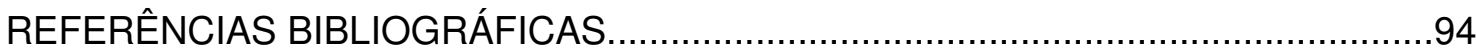

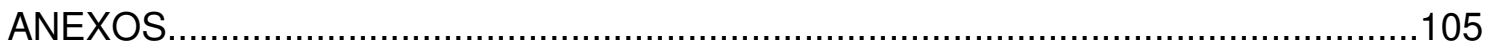

Anexo 1: Mapas Geológicos, escalas 1:500.000 e 1:250.000

Anexo 2: Mapas Geológicos e Seções Geológicas, escala 1:100.000

Anexo 3: Tabela de pontos 


\section{INTRODUÇÃO}

Os Andes Centrais possuem uma complexa história tectônica, marcada por diversas fases de deformação, metamorfismo e magmatismo. O acúmulo do conhecimento sobre a idade, composição e evolução das diferentes massas siálicas que compõem a porção noroeste da Argentina, aumentou consideravelmente nos últimos anos em função dos estudos desenvolvidos por diversos grupos de pesquisa, principalmente nas regiões das Sierras Pampeanas e Pré-Cordilheira.

Considerando os episódios de docagem e acresção de terrenos na borda ocidental do supercontinente Gondwana, distintos blocos geológicos do centro/noroeste argentino foram divididos nos seguintes terrenos, de leste para oeste, Pampia, Famatina, Cuyania (ou Pré-Cordilheira) e Chilenia (Quernadelle \& Ramos, 1999). Há grande discussão a respeito da origem desses terrenos (Aceñolanza et al., 2002; Dalla Salda et al., 1992; Keller, 1999; Ramos et al., 1986; Ramos, 1999a, 1999b, 2004 e 2008; Thomas \& Astini, 1996 e 2003, entre outros), porém admitem-se os terrenos Pampia e Famatina como gondwânicos ou para-autóctones, e Cuyania e Chilenia como alóctones.

As Sierras Pampeanas, que consistem em blocos de embasamento soerguidos e rotacionados no Cenozóico Superior pela tectônica compressiva no retroarco dos Andes Centrais ("The Pampean Flat-Slab" de Ramos et al., 2002), caracterizam-se por rochas ígneas e metamórficas dos terrenos Pampia, Famatina e parte Cuyania, formadas nos diversos episódios orogênicos experimentados pela protomargem Andina.

Caminos (1979) separou as Sierras Pampeanas em Sierras Pampeanas Orientais e Ocidentais; na primeira englobou xistos e gnaisses psamo-pelíticos e os corpos graníticos e migmatitos; na segunda ocorreriam mármores, anfibolitos, rochas ígneas básicas-ultrabásicas, e escassas rochas graníticas.

Ao longo das Sierras Pampeanas Ocidentais até os blocos de San Rafael e Las Matras, ocorre uma faixa N-S de rochas de idades mesoproterozóicas grenvilianas, pertencentes ao embasamento do Terreno Cuyania (Sato et al., 2000). Incluem as serras de Toro Negro, Umango, Maz e Espinal ao norte; Sierra de La Huerta/Sierra Valle Fértil e Sierra de Pie de Palo na porção central; e blocos de San Rafael e Las Matras ao sul (Sato et al., 2000) (Figura 1). 


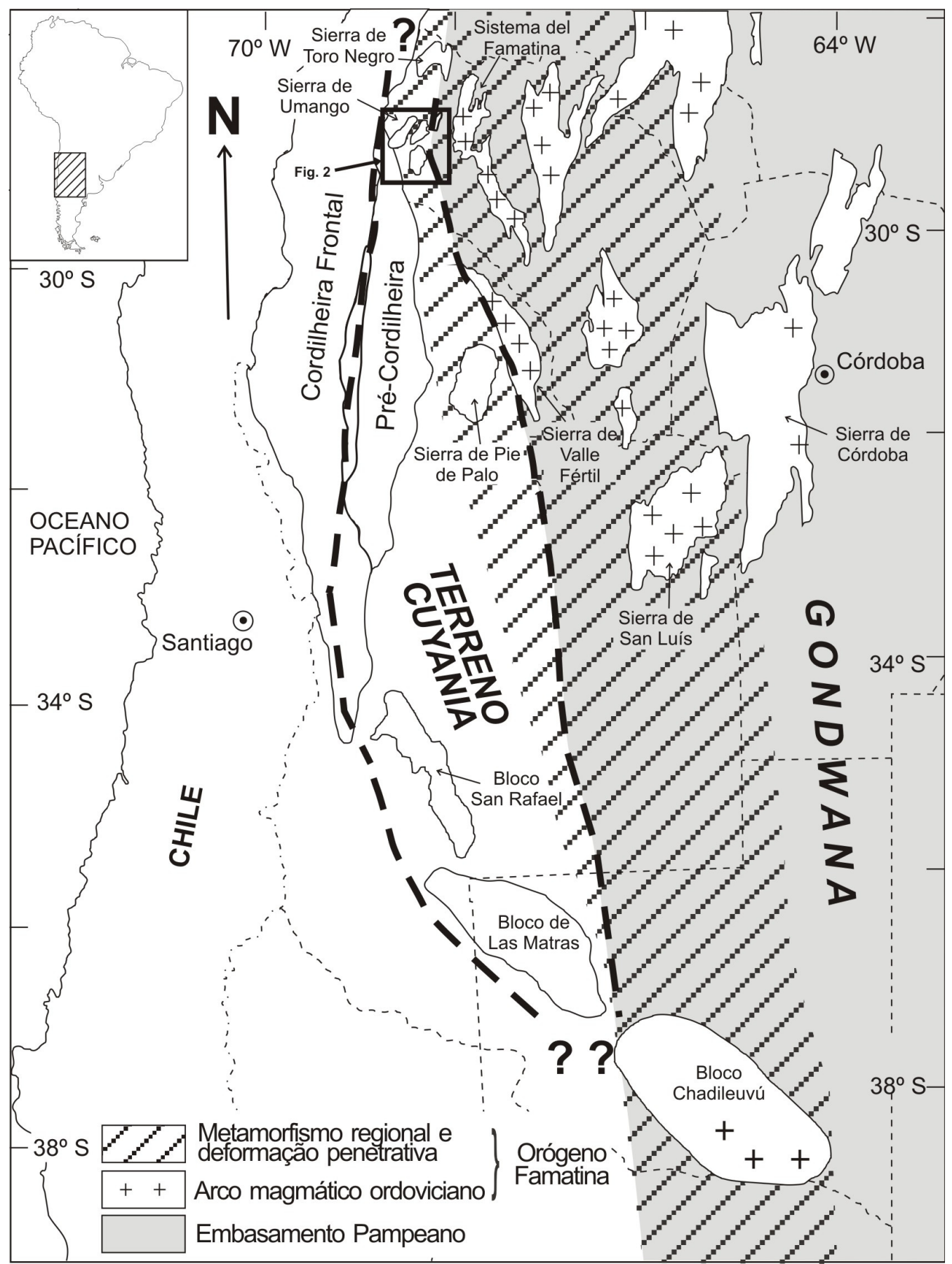

Figura 1: Relações tectônicas no Paleozóico Inferior entre a protomargem Andina de Gondwana e o Terreno acrescionário Cuyania (Modificado de Sato et al., 2004).

As serras de Umango, Maz e Espinal compõem blocos de rochas metaígneas e metassedimentares aflorantes entre as latitudes $28^{\circ} 45^{\prime}$ e $29^{\circ} 30^{\prime} \mathrm{S}$ e longitudes $68^{\circ} 50^{\prime}$ e $68^{\circ} 15^{\prime}$ W, na região sudoeste da Província de La Rioja, Argentina. Encontram-se limitadas a oeste por rochas sedimentares devonianas (Formação Punilla) pertencentes à Pré-Cordilheira Ocidental, e a leste por rochas graníticas, vulcânicas e sedimentares pertencentes ao Sistema de Famatina (Figura 2). 
Figura 2 (página seguinte): Mapa geológico regional em escala 1:500.000, baseado em Kilmurray \& Dalla Salda (1971), Casquet et al. (2008a), Caminos \& Fauqué (1999) e Fauqué et al. (2004), com indicação das cidades e locais para acampamento e repouso (puestos) na Sierra de Umango e proximidades (para localização geográfica ver Figura 1).

\section{UNIDADES GEOLÓGICAS:}

QUATERNÁRIO: 36 - Barreal; 35 - Quaternário Indiferenciado; NEÓGENO

\section{BACIAS TERCIÁRIAS}

PLIOCENO SUPERIOR: 34 - Formações EI Corral e Toro Negro;

PLIOCENO: 33 - Plioceno Indiferenciado;

PLICOENO INFERIOR: 32 - Formação Zapallar;

MIOCENO MÉDIO/SUPERIOR: 31 - Formação Vinchina;

30 - Rochas vulcânicas terciárias;

MIOCENO MÉDIO: 29 - Formação Cerro Morado;

OLIGOCENO/MIOCENO INFERIOR: 28 - Formação Puesto La Flecha;

MESOZÓıCO

BACIA DO ISCHIGUALASTO

CRETÁCEO: 27 - Formação Ciénaga del Rio Huaco;

TRIÁSSICO: 26 - Triássico Indiferenciado;

PALEOZÓICO

BACIA PAGANZO

PERMIANO: 25 - Formações Rio del Peñon, Patquia e Panacán;

CARBONíFERO SUPERIOR: 24 - Formações Tupe e Vólcan;

CARBONIFERO INFERIOR/SUPERIOR: 23 - Formação Guandacol;

CARBONÍFERO: 22 - Granitóides Indiferenciados;

PRÉ-CORDILHEIRA

DEVONIANO SUPERIOR/CARBONÍFERO INFERIOR: 21 - Formação Punilla;

ORDOVICIANO: 20 - Grupo Trapiche; 19 - Sequência Carbonática La Troya;

CAMBRIANO/ORDOVICIANO: 18 - Formações Cerro Totora e San Juan;

ARCO MAGMÁTICO FAMATINA

ORDOVICIANO: 17 - Granitóides;

SIERRAS DE MAZ E DEL ESPINAL

16 - Formação Espinal; 15 - Grupo El Zaino; 14 - Grupo El Taco; 13 - Anortositos; 12 - Grupo Maz;

SIERRA DE UMANGO

CARBONÍFERO: 11 - Granito Cerro Veladero (GRANITO PÓS-OROGÊNICO);

SILURIANO: 10 - Granitos Guandacolinos (GRANITO TARDI-OROGÊNICO);

ORDOVICIANO/SILURIANO?: 9 - Unidade EI Cordobés (ROCHAS METABÁSICAS);

ORDOVICIANO: 8 - Granito EI Peñon (GRANITO SIN-OROGÊNICO);

METAMORFISMO ORDOVICIANO E SEDIMENTAÇÃO DE IDADE DESCONHECIDA:

UNIDADE TAMBILLITO: 7 - Metagabro; 6 - Sequência Metassedimentar;

UNIDADE TAMBILLO: 5 - Mármores; 4 - Sequência Metavulcanossedimentar; 3 - Metagabro com granada; 2 - Milonitos ZCCP;

MESOPROTEROZÓICO - ESTENIANO: 1 - Ortognaisses Juchi; 


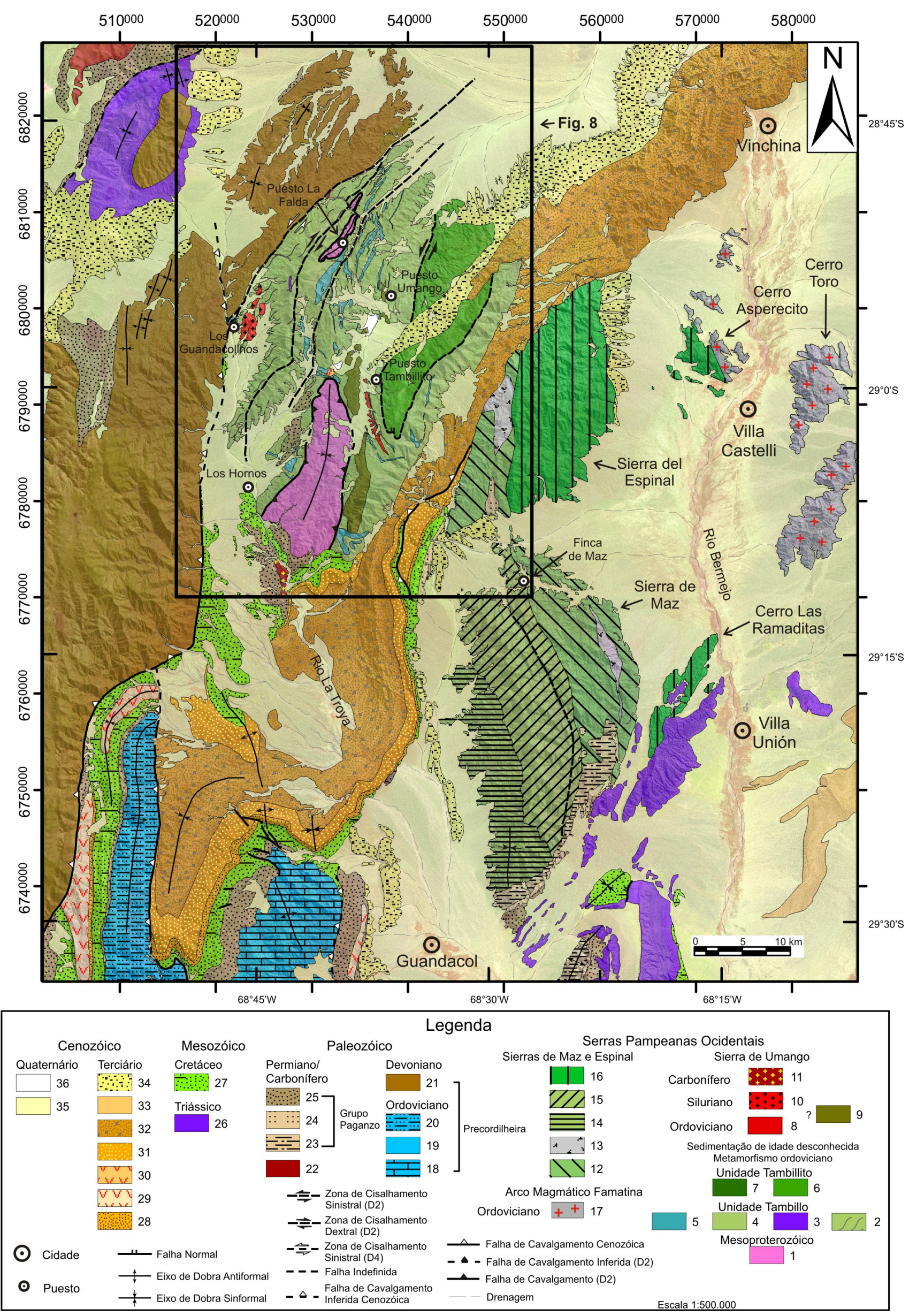


A variedade de litotipos e complexidade estrutural da Sierra de Umango vêm sendo reportadas desde os trabalhos de Hausen (1921) e Furqué (1972) até os recentes trabalhos com ênfase em geocronologia, geoquímica (Varela et al., 1996, 2000, 2001, 2003a, 2003b, 2008) e evolução termo-tectônica (Porcher et al., 2004).

$\mathrm{Na}$ Sierra de Umango foram reconhecidas seis unidades geológicas (Varela et al., 2008). A unidade mais antiga corresponde aos Ortognaisses Juchi, de idade mesoproterozóica (Varela et al., 1996). Duas seqüências metassedimentares foram denominadas: Tambillo e Tambillito. A primeira corresponde a uma seqüência siliciclástica/carbonática com rochas básicas intercaladas e é considerada com idade de sedimentação do Neoproterozóico tardio ao início do Cambriano (Varela et al., 2001), enquanto que a segunda caracteriza-se por um pacote siliciclástico intrudido por rochas básicas de idade mesoproterozóica (Varela et al., 2008). Granitos sincolisionais (Granito Él Peñon), rochas metabásicas tardicolisionais (Unidade El Cordobés) e granitos tardi a póscolisionais (Granitos Los Guandacolinos e Cerro Veladero) completam o quadro litológico que compõem as rochas ígneas e metamórficas da Sierra de Umango (Varela et al., 2008).

Bacias sedimentares extensionais invertidas do Paleozóico Superior (Bacia Paganzo de idade Carbonífera a Permiana) e do Mesozóico (bacias cretácicas e triássicas), e bacias de retroarco cenozóicas repousam discordantes sobre as rochas do embasamento da Sierra de Umango.

Esta dissertação integra estudos geológicos detalhados ao longo de seções em drenagens ("quebradas"), baseado em técnicas de análise estrutural e microtectônica, e busca reconhecer os eventos metamórficos e deformacionais na Sierra de Umango para a elaboração de uma proposta de evolução geodinâmica.

\section{OBJETIVOS}

A complexidade estrutural e metamórfica das rochas da Sierra de Umango requer estudos geológicos de detalhe que deverão contribuir para as pesquisas apresentadas nos últimos anos, em maior parte, geocronológicas e geoquímicas.

Os diversos dados geocronológicos da região possuem significados geológicos incertos devido à escassa informação em relação às estruturas principais da serra.

O presente trabalho busca entender as relações de contato entre as unidades da Sierra de Umango, caracterizar a cinemática e a estrutura principal da serra, considerando o impacto dessas características no quadro tectônico regional.

Pontualmente, os resultados a serem alcançados são:

- confecção de mapa geológico em escala 1:250.000; 
- confecção de seções geológicas transversais em escala 1:100.000;

- reconhecimento e hierarquização das principais fases de deformação;

- proposta de evolução geológico-estrutural para a Sierra de Umango.

\section{MATERIAIS E MÉTODOS}

Para o alcance dos objetivos listados, o trabalho contou com extenso levantamento bibliográfico e com a utilização de elementos de cartografia e sensoriamento remoto, petrologia metamórfica, análise estrutural e microestrutural.

A pesquisa bibliográfica foi feita, em maior parte, na biblioteca do IGc-USP e internet, principalmente pelo site dos periódicos CAPES. Contou ainda com bibliografias disponibilizadas pela biblioteca da Universidade de La Plata, Argentina.

Foram utilizadas como base cartográfica imagens de satélite LANDSAT (ETM+) e ASTER (VNIR e SWIR) e a base topográfica digitalizada SRTM (Shuttle Radar Topografic Mission) - 90m. O tratamento das imagens de satélite em ambiente computacional georreferenciado (software ENVI) permitiu a produção de composições coloridas que auxiliaram na interpretação de continuidade lateral das unidades e associações litológicas na região. A composição colorida da imagem LANDSAT $(E T M+)$ utilizada para a confecção do mapa geológico foi a 472 (banda 4 no canal $R$, banda 7 no canal G e banda 2 no canal B) com fusão da imagem pancromática e filtro de realce de bordas do tipo Laplace. Imagens fornecidas pelo software Google Earth também foram utilizadas na interpretação geológica da área de estudo.

Os mapas geológicos previamente publicados, tais como Caminos \& Fauqué (1999), Casquet et al. (2008a), Fauqué et al. (2004), Porcher et al. (2004) e Varela et al. (2008), serviram como base para a interpretação geológica. Os mapas foram confeccionados utilizando o software ARCGIS e posteriormente editados no software CorelDraw.

Quatro etapas de levantamento geológico de campo foram realizadas na região. Os dados geológicos foram coletados em duas etapas de campo anteriores a esta pesquisa de mestradopor Miguel A. S. Basei em 2002 (pontos na centena de 400) e Mário C. Campos Neto e Miguel A. S. Basei em 2003 (pontos na centena de 500). Duas etapas no início dos anos de 2008 (pontos nas centenas de 600 e 700) e 2009 (pontos na centena de 800) contaram com a presença do autor deste trabalho.

Além da descrição detalhada das estruturas, texturas e mineralogia das rochas no campo, os dados coletados serviram para estudos de petrografia microscópica e análise estrutural. 
A petrografia microscópica foi feita com ênfase na caracterização de microestruturas e texturas metamórficas sempre acompanhadas das definições apresentadas em Passchier \& Trouw (1996) e Vernon (2004). As fácies metamórficas e condições $P-T$ das rochas estudadas foram estimadas segundo as grades petrogenéticas publicadas em Spear (1993) e Vernon \& Clarke (2008).

As estruturas foram classificadas e hierarquizadas de modo coerente seguindo recomendações de Ramsay \& Huber (1983) e (1987). A análise estrutural foi feita com base nos dados coletados no campo e com a geração e interpretação de estereogramas. Os estereogramas foram gerados em rede de Schmidt-Lambert no hemisfério inferior utilizando o software Stereonett, e posteriormente editados com o auxílio do software CorelDraw.

\section{GEOLOGIA REGIONAL}

\subsection{Andes Centrais - Contextualização e Interpretações Geotectônicas}

Os Andes formam uma extensa cadeia de montanhas que percorre da Venezuela à Terra do Fogo mais de $8.000 \mathrm{~km}$. Marca o limite do Oceano Pacífico na América do Sul e representa um típico orógeno não colisional, como proposto por Dewey \& Bird (1970), formado pela subducção de crosta oceânica sob crosta continental.

A análise de diferentes setores da Cordilheira Andina exibe grande complexidade de processos geodinamicamente controlados pelo ângulo de subducção, pelas placas tectônicas envolvidas e suas distintas histórias pretéritas. Gansser (1973) propôs a divisão dos Andes em Andes do Norte, Andes Centrais e Andes do Sul considerando as diferenças morfológicas, estruturais e geológicas. Ramos \& Aleman (2000) adotaram a proposta de Gansser (1973) julgando-a apropriada para analisar a história dos diferentes segmentos andinos, mas subdividiram-na como apresentado na Figura 3.

Segundo Gansser (1973) os Andes Centrais se estendem do Golfo de Penas, Chile (Cadeia Submarina do Chile - subducção do limite entre as placas de Nazca e Antárctica) até a Baía de Guayaquil, Equador (Cadeia Submarina Carnegie). A região onde está situada a área de estudo é influenciada pela subducção de baixo ângulo da placa de Nazca sob a placa Sulamericana e foi denominada de "Pampean Flat-Slab" por Ramos \& Aleman (2000). A característica tectônica do Neógeno na região é a ausência de vulcanismo e a presença de regime compressivo no retroarco. 


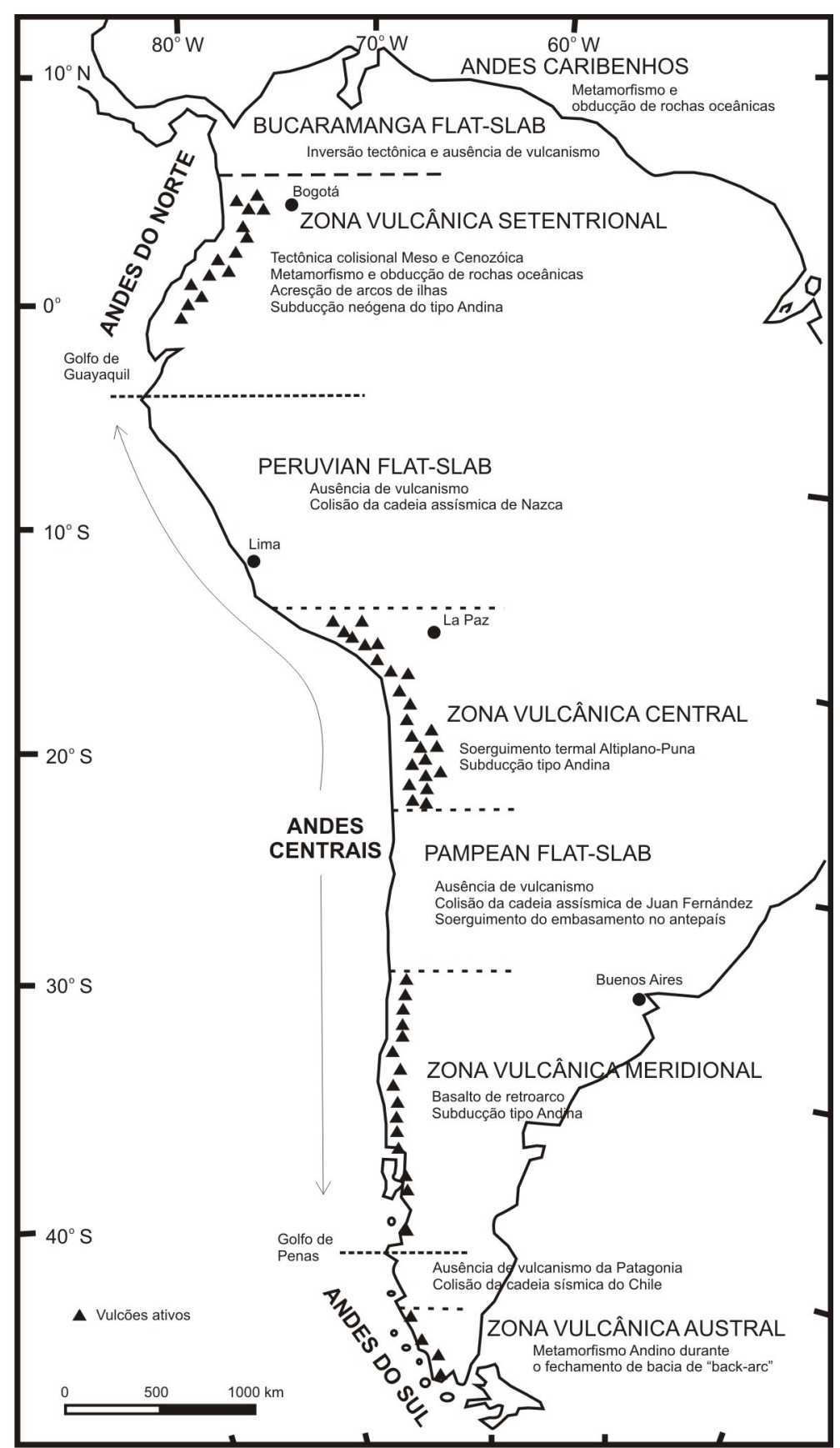

Figura 3: Principais segmentos da Cordilheira Andina e os processos mais importantes envolvidos durante a formação de cada um deles (Modificado de Ramos \& Aleman, 2000).

A história geológica andina vem sendo explorada por diversos pesquisadores desde meados do século passado, com o intuito de discutir os processos formadores dessa extensa cadeia de montanhas. Sua complexidade é reportada em vários trabalhos (p.e. Gansser, 1973; Coira et al., 1982; Ramos et al., 1986; Ramos 1988a, 1988b, 1999a e 1999b; Dalla Salda et al., 1992a; Ramos \& Aleman, 2000).

O reconhecimento da importância de terrenos acrescionários ou "suspeitos" como relevantes processos geodinâmicos na acresção continental veio à tona 
principalmente na década de 80, com os trabalhos de Coney et al. (1980), Jones et al. (1983) e Howell (1989).

Terrenos "suspeitos" paleozóicos acrescidos à borda ocidental do Gondwana foram descritos por Ramos et al. (1986). Segundo os autores, as rochas dos Andes Centrais com idades do Paleozóico Inferior e Médio podem ser divididas em terrenos de acordo com as características proposta por Coney et al. (1980). A evolução do conhecimento geológico e das propostas de divisões dos terrenos nos Andes Centrais leva à grande especulação e discussão científica.

Ramos et al. (1986) identificaram três terrenos de história acrescionária précarbonífera. De leste para oeste foram nomeados os terrenos Pampeano, PréCordilheira e "Chilenia". O Terreno Pampeano corresponderia a rochas magmáticas e metamórficas de idades cambriano-devonianas sobre embasamento Neoproterozóico e englobaria todas as Sierras Pampeanas, incluindo as serras de Pie de Palo, Valle Fértil, Umango/Maz/Espinal e Famatina (Ramos et al., 1986). O Terreno PréCordilheira (principal elemento para a interpretação tectônica apresentada) aglutinaria a mais completa exposição estratigráfica do Paleozóico Inferior e Médio, com as melhores evidências estruturais e petrológicas para delimitar os principais limites tectônicos entre os terrenos (Ramos et al., 1986). As principais evidências para a natureza alóctone do embasamento da Cordilheira Frontal Andina ("Chilenia") são as relações que demonstram a existência de uma bacia oceânica a oeste do Terreno PréCordilheira (Ramos et al., 1986). A presença de intrusões plutônicas do Paleozóico Superior até o Neógeno, rochas vulcânicas e sedimentares recobriram e obliteraram fortemente as rochas que constituíam "Chilenia" (Ramos et al., 1986). A combinação de indicadores diretos e indiretos de embasamento continental e a presença de uma faixa de rochas máficas e ultramáficas sob o lado oeste da Pré-Cordilheira, derivadas de materiais de crosta oceânica de idade Ordoviciana Superior, suportam a existência do Terreno Chilenia (Ramos et al., 1984 e 1986).

A superposição de diferentes ciclos orogênicos formou uma série de províncias geológicas com diferentes histórias geológicas na região dos Andes Centrais (Ramos et al., 1988a). Em geral associam-se a combinações de subducções e colisões com as sucessões orogenéticas migrando para oeste (Ramos et al., 1988a). Os ciclos tectônicos, seus principais estágios orogênicos e as províncias geológicas relacionadas estão apresentados na Tabela 1.

Segundo Ramos et al. (1988a), a Pré-Cordilheira representaria uma plataforma carbonática do Cambriano Inferior/Ordoviciano, associada à margem passiva da antiga borda oeste do supercontinente Gondwana. Para os mesmos autores as rochas ígneas do Cambriano ao Ordoviciano Superior das Sierras Pampeanas 
corresponderiam a um arco magmático associado à subducção para leste na margem oeste do Gondwana.

Tabela 1: Províncias Geológicas dos Andes Centrais e Ciclos Tectônicos (Modificado de Ramos, 1988b).

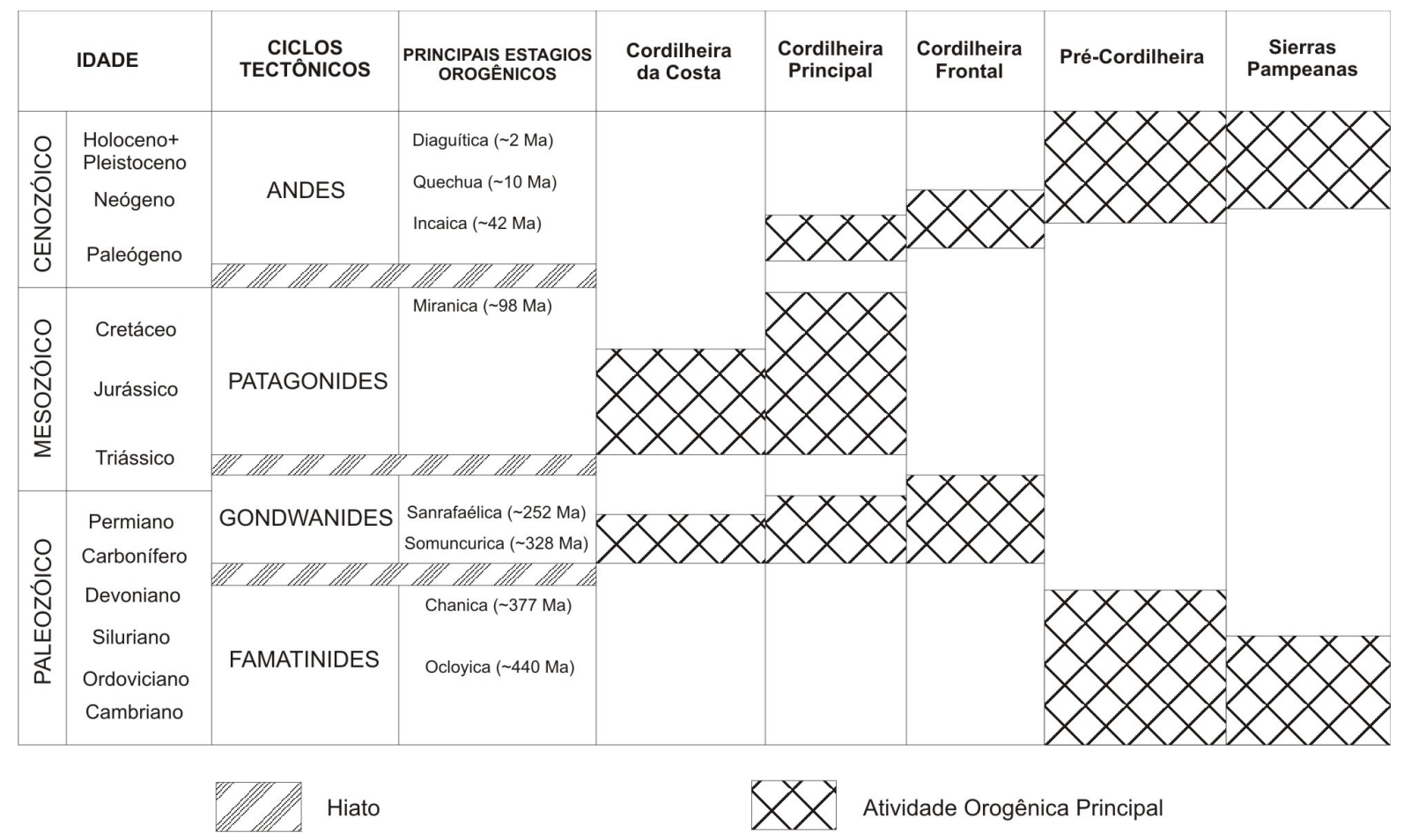

O ciclo tectônico Famatina apresenta dois eventos principais de metamorfismo e magmatismo, a orogênese Ocloyica (ordoviciana) e a orogênese Chanica (devoniana) (Tabela 1). O magmatismo é mais importante na orogênense Ocloyica, principalmente na Faixa Eruptiva de La Puna e Sierras Pampeanas, e a orogênese Chanica estaria associada à deformação causada pelo fechamento de oceano, colisão e acresção do Terreno alóctone "Chilenia" e conseqüente migração da subducção para oeste (Ramos et al., 1988a).

O ciclo tectônico Gondwanides, no Paleozóico Superior, teve início com a implantação de um sistema de subducção simples de uma placa oceânica sob uma margem continental (Ramos et al., 1988a). Esse sistema foi responsável por sedimentação (deposição de bacias extensionais de retroarco - e.g. Bacia Paganzo) e tectônica acrescionária (batólitos intrusivos cordilheiranos) na borda oeste do continente (Ramos et al., 1988a).

O ciclo tectônico Patagonides representa uma série de fases de deformação que começaram no Jurássico até o final do Cretáceo Superior (Ramos et al., 1988a). O principal episódio compressivo é chamado de orogênese Miranica (Ramos et al., 1988a). O ciclo Patagonides é fortemente associado aos estágios pré-rifte, rifte e 
deriva da margem leste do continente, produzida pela abertura do Atlântico Sul (Ramos et al., 1988a).

O ciclo tectônico Andino é responsável pela configuração atual dos Andes e é caracterizado por diferentes regimes de subducção (Ramos et al., 1988a). Teve início no Terciário Inferior e continua atuante, com variações de períodos de intenso magmatismo e períodos de magmatismo ausente com regime compressivo no retroarco (Ramos et al., 1988a). Os diversos estágios de compressão no retroarco causaram o soerguimento da Pré-Cordilheira e das Sierras Pampeanas, caracterizados por dobras e falhas inversas orientadas paralelamente à subducção e vergentes para leste (Pré-Cordilheira "fold and thrust belt") (Ramos et al., 1988a).

Outra proposta de interpretação tectônica para os Andes Centrais foi apresentada por Dalla Salda et al. (1992a). Os autores interpretam o orógeno Famatina como uma faixa móvel de idade neoproterozóica a paleozóica inferior/média ao longo da borda oeste do Gondwana. Essa faixa móvel representaria a colisão do Terreno Occidentalia contra a protomargem Andina do Gondwana.

O Terreno Occidentalia integraria os blocos continentais alóctones ArequipaBelen-Antofalla, Mejillones e Chilenia, o Terreno Pré-Cordilheira e a faixa oeste do Terreno Pampeano (Sierras Pampeanas Ocidentais) de Ramos et al. (1986) (Dalla Salda et al., 1992a). Occidentalia representaria um fragmento da porção leste do supercontinente Laurentia, rifteado e posteriormente acrescido ao Gondwana no Ordoviciano (Dalla Salda et al., 1992a).

Diferentemente de Ramos et al. (1986), Dalla Salda et al. (1992a) propõem a existência de um oceano aberto à leste da Pré-Cordilheira durante o Cambriano e Ordoviciano Inferior. As fácies sedimentares de oceano profundo de idades do Ordoviciano Médio a Superior expostas na Pré-Cordilheira Ocidental, assim como os ofiolitos do Ordoviciano Superior intercalados nessas rochas corresponderiam a uma bacia interior de rifte (Dalla Salda et al., 1992a).

Dalziel (1991) evoluiu a hipótese de um supercontinente Neoproterozóico onde a protomargem Apalachiana do Laurentia e a protomargem Andina do Gondwana estavam unidas. Para o autor, os dados paleomagnéticos indicariam uma trajetória horária do supercontinente Laurentia rodeando a protomargem Andina do Gondwana até a posição de configuração do Pangea no Permiano.

Segundo essa hipótese, Laurentia e América do Sul estavam justapostas no Ordoviciano. Dalla Salda et al. (1992a) consideram que a colisão entre Laurentia e Gondwana pode ter sido a principal causa do evento tectônico Famatina (540-330 $\mathrm{Ma})$. 
A proposta de Dalziel et al. (1994) supõem que o supercontinente Laurentia estava justaposto à margem pacífica do leste australiano-Antártica durante o Neoproterozóico (configuração de Rodínia). Com a fragmentação de Rodínia, iniciada a aproximadamente $750 \mathrm{Ma}$, Laurentia teria passado por rifteamento e nova amalgamação com Gondwana em $600 \mathrm{Ma}$, quando constituiu um novo supercontinente conformado por Gondwana, Laurentia, Báltica e Siberia (Dalziel et al., 1994), nomeado posteriormente de Pannotia (Dalziel, 1997).

Como apresentado por Dalla Salda et al. (1992b), os orógenos Apalachiano e Ocloyico foram formados conjuntamente em um evento de colisão no Ordoviciano. $O$ posterior rifteamento separou Laurentia de Gondwana, deixando o Terreno Occidentalia amalgamado no supercontinente Gondwana.

Dalziel et al. (1994) sugerem ainda que a Orogênese Acadiana, no leste da América do Norte, faça parte de uma colisão transpressiva entre Laurentia e Gondwana, pós-separação Taconica/Ocloyica e pré-amalgamação final de Pangea (colisão entre Laurentia e noroeste da África).

A presença de um complexo de rochas básicas e ultrabásicas de idade Grenviliana (Complexo Pie de Palo) na porção oeste da Sierra de Pie de Palo (Sierras Pampeanas Ocidentais) levou Ramos et al. (1996) considerarem o terreno, anteriormente chamado de Pré-Cordilheira por Ramos et al. (1986), como terreno composto, denominando-o de Terreno Composto Cuyania. O Complexo Pie de Palo foi justaposto pela faixa de cavalgamento La Pirquitas sobre a seqüência clástica e de plataforma carbonática do Grupo Caucete (Neoproterozóico?) (Ramos et al., 1996). Ramos et al. (1996) consideram que a acresção entre o embasamento de Pie de Palo e o embasamento Grenviliano da Pré-Cordilheira ocorreu antes da colisão final do terreno composto contra a protomargem do Gondwana durante o Ordoviciano Médio.

Com base em idades ${ }^{40} \mathrm{Ar} /{ }^{39} \mathrm{Ar}$ obtidas em concentrados de muscovita e anfibólio, provenientes de variados tipos de rochas em diferentes setores tectônicos da Sierra de Pie de Palo e arredores, Ramos et al. (1998) consideram que a colisão entre - Terreno Composto Cuyania e a protomargem do Gondwana iniciou-se no Ordoviciano Médio (cerca de $470 \mathrm{Ma}$ ) com idades platôs chegando até cerca de 394 Ma. A distribuição das idades obtidas no tempo e espaço é relacionada ao complexo sistema de deformação dúctil, falhas e falhas inversas que afetaram o embasamento da Sierra de Pie de Palo (Ramos et al., 1998). As idades associadas aos últimos períodos de soerguimento e resfriamento foram interpretadas como o início da deformação relacionada à colisão do Terreno Chilenia (Ramos et al., 1998).

O transporte para oeste das falhas e cavalgamentos, assim como o registro sedimentar e fossilífero das bacias de antepaís, mostram a coincidência entre a 
evolução temporal das bacias e os períodos de soerguimento e resfriamento derivados das idades platôs ${ }^{40} \mathrm{Ar} /{ }^{39} \mathrm{Ar}$ (Ramos et al., 1998).

O modelo de evolução geotectônica apresentado por Quernadelle \& Ramos (1999) aponta o início da subducção e da formação de arco magmático ao longo da protomargem do Gondwana no Cambriano Médio (515-510 Ma, associado à idade mais antiga de granitóides pré-tectônicos - Ortognaisses La Puntilla, Sierra de Fiambalá). O período de desenvolvimento do arco magmático durou até o Ordoviciano Inferior (470 Ma) (Figura 4a). Segundo os autores, entre o Ordoviciano Médio e Superior (470-460 Ma) ocorrem intrusões de granitos sincolisionais associados à colisão do Terreno Famatina contra a protomargem de Gondwana (Figura 4b), seguido da colisão de Cuyania (Figura 4c). Os mesmos autores consideram Famatina como um terreno independente acrescido à Gondwana entre 470-460 Ma, como proposto anteriormente por Conti et al. (1996), desfavorecendo a proposta de Toselli et al. (1996), que consideram a presença de uma bacia de "back arc" separando Famatina das Sierras Pampeanas. Pankhurst et al. (1998) interpretam Famatina como o arco magmático da protomargem do Gondwana, pertencente às Sierras Pampeanas Orientais.

Para Ramos (1999b), a colisão de Cuyania (Figura 4c) estaria associada diretamente ao início do magmatismo sincolisional e ao término da atividade magmática do arco de Famatina.

Com base no registro sedimentar e estratigráfico da Pré-Cordilheira, Astini \& Thomas (1999) documentam os estágios de aproximação e colisão do Terreno PréCordilheira (ou Cuyania) contra a zona de subducção ao longo da margem ativa do Gondwana Ocidental (bacias de antepaís da Figura 4c). Os autores consideram esse estágio vinculado à subsidência flexural progressiva (geração de depocentros anóxicos, com tectonismo como principal controle de espaço de acomodação), caracterizado por unidades siliciclásticas do Ordoviciano Médio que progradam para uma cunha clástica de paleogeografia complexa no sentido oeste. Nesse estágio, há a mudança geral de ambiente dominado por carbonatos para ambiente dominado por sedimentos siliciclásticos (Astini \& Thomas, 1999).

A identificação de dobras e falhas de cavalgamento com transporte para oeste, nas rochas sedimentares da Pré-Cordilheira próximo à cidade de Guandacol, trouxe novos artifícios para a discussão e interpretação dos processos sedimentares e tectônicos que envolveram a transição entre margem passiva e bacia periférica de antepaís (Thomas \& Astini, 2007). Thomas \& Astini (2007) interpretaram essas estruturas como parte de uma faixa de cavalgamentos epidérmicos ("thin-skinned 
thrust belt') Ordoviciana, associada à Orogênese Ocloyica (ou Guandacol, de acordo com Pankhrust \& Rapela, 1998, ver Tabela 2).
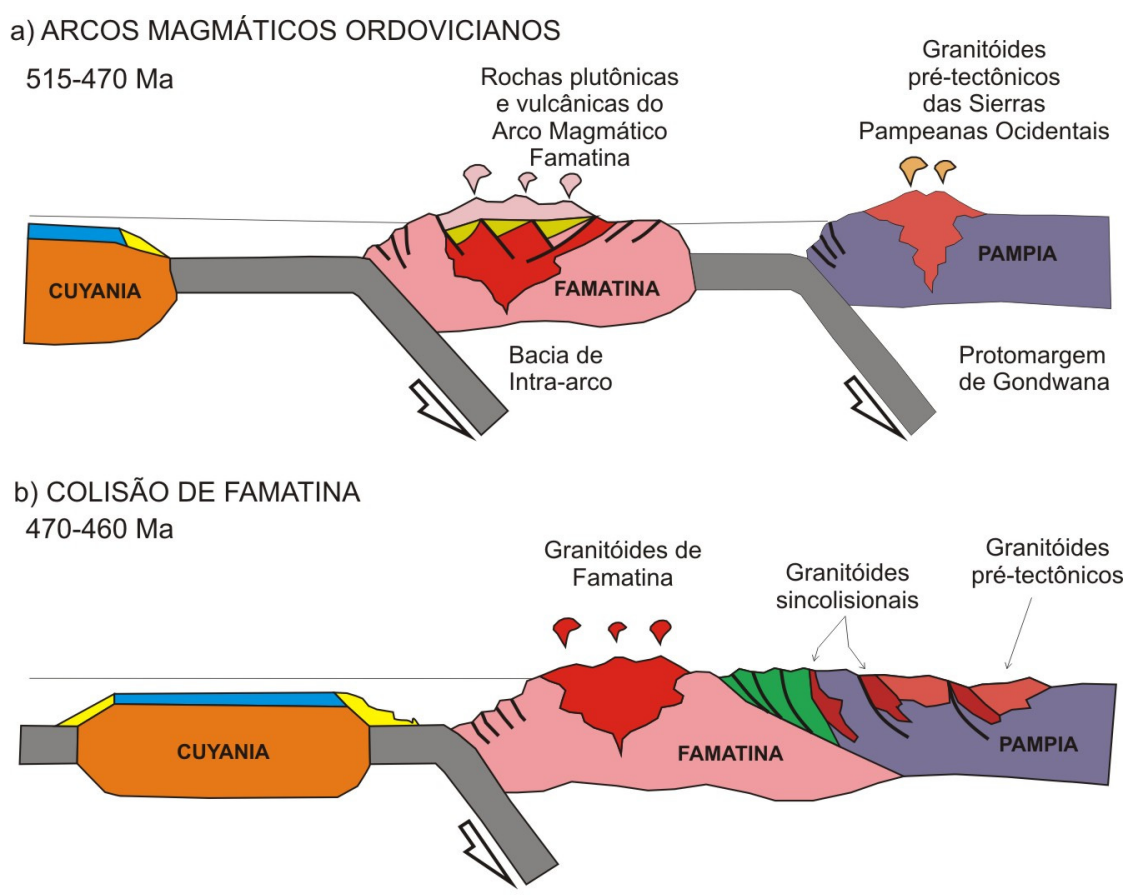

c) COLISÃO DE CUYANIA

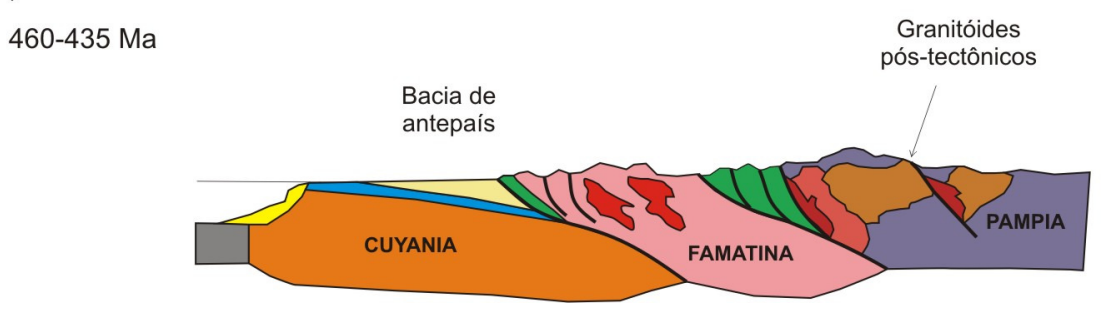

Figuras 4 a, b, c: Modelo de evolução geotectônica dos Andes Centrais durante o Ciclo Famatiniano (Modificado de Quernadelle \& Ramos, 1999). Ver discussão no texto.

Ramos (1999b) descreve ainda a colisão e amalgamento do Terreno Chilenia a partir do Devoniano Inferior, com o desenvolvimento de outra bacia periférica de antepaís no Devoniano Médio a Superior.

Após a cratonização do embasamento das Sierras Pampeanas, caracterizado principalmente por intenso magmatismo anorogênico, há a implantação de bacias de rifte com sedimentação de conglomerados e arenitos vermelhos ("red beds") do Grupo Paganzo (Bacia Paganzo) (Quernadelle \& Ramos, 1999).

Pankhurst \& Rapela (1998) resumem os ciclos orogênicos ocorridos ao longo da margem pacífica da América do Sul no Fanerozóico (Tabela 2) da seguinte forma:

a) Ciclo Pampeano (Neoproterozóico-Cambriano Superior)

Considerado o mais importante evento orogenético no sudoeste do Gondwana. Ao longo da porção sul da protomargem Andina, o Ciclo Pampeano inclui a formação 
de bacia sedimentar de margem passiva (relacionado à quebra de Rodínia), colocação de uma seqüência de granitóides cálcio-alcalinos metaluminosos (associada à subducção para NE sob o cráton Rio de La Plata), dobramentos e metamorfismo de baixo a alto grau (vinculado à colisão do Terreno Pampeano contra a margem do cráton Rio de La Plata) e finalmente colapso extensional do orógeno (Rapela et al., 1998).

b) Ciclo Famatiniano (Ordoviciano Inferior-Carbonífero Inferior)

O principal episódio orogênico/acrescionário da protomargem Andina iniciou-se com subducção a aproximadamente 490 Ma. É alvo de grande discussão acadêmica, inclui a orogenia Famatina no antepaís Gondwânico, a colisão do Terreno Cuyania (ou Pré-Cordilheira) e a colisão do Terreno Chilenia. Fases orogênicas como Guandacol, Ocloyica, Pré-Cordilheirana e Chanica são associadas a esse ciclo tectônico e frequentemente são interpretadas como produto do amalgamento dos terrenos à protomargem Andina. Intrusões graníticas intraplaca em Gondwana foram tentativamente inclusas como últimos eventos do Ciclo Famatiniano (Tabela 2).

c) Ciclo Gondwânico (Carbonífero Inferior-Cretáceo Inferior)

Período caracterizado por tectônica extensiva e relativa estabilidade do supercontinente Gondwana, do Carbonífero Inferior (cerca de 330-340 Ma) à quebra final do supercontinente. Após as orogenias e os eventos acrescionários do Paleozóico Inferior e Médio ocorrem intrusões de batólitos carboníferos do tipo Cordilheirano, associados a um novo regime de subducção ao longo da protomargem Andina. Desenvolvimento de províncias riolíticas e bacias sedimentares extensionais do Permiano ao Triássico (incluindo as bacias Paganzo, Rio Blanco e Ischigualasto), e cinturões plutônicos cordilheiranos são característicos do Ciclo Gondwânico.

d) Ciclo Andino (Cretáceo Inferior-Presente)

O Ciclo Andino teve seu início vinculado à abertura do Oceano Atlântico Sul e à separação da América do Sul da placa Africana-Indiana. Esse evento está intimamente ligado à extrusão da Província Basáltica Paraná-Etendeka (cerca de 130 Ma). A geração de rochas plutônicas e vulcânicas típicas dos Andes modernos tornouse predominante com o aumento da velocidade de convergência entre a protomargem Andina e a recentemente formada placa da América do Sul. O termo "Orogenia Andina" é geralmente associado a diversas fases compressivas durante esse período, mas é comumente utilizado para as compressões modernas e terciárias. Formação de bacias extensionais intracontinentais e da margem passiva Atlântica também são típicas do Ciclo Andino.

As estruturas pré-existentes do embasamento da Cordilheira Andina e das Sierras Pampeanas tiveram papel importante na história do soerguimento dessa 
região no Cenozóico Superior (Figura 5). A deformação e o soerguimento nas Sierras Pampeanas mostram clara associação com a migração para leste do magmatismo de arco (Ramos et al., 2002). Essa relação implica que deformação e soerguimento são mais relacionáveis ao enfraquecimento termal ("thermal weakening") e à anisotropia crustal que flutuações no esforço compressivo horizontal (Ramos et al., 2002).

Tabela 2: Representação esquemática dos eventos geológicos principais reconhecidos na história Paleozóica da Protomargem de Gondwana, com a comparação entre os eventos ocorridos no Terreno alóctone Pré-Cordilheira e no antepaís Gondwânico (Sierras Pampeanas) (Modificado de Pankhurst \& Rapela, 1998).

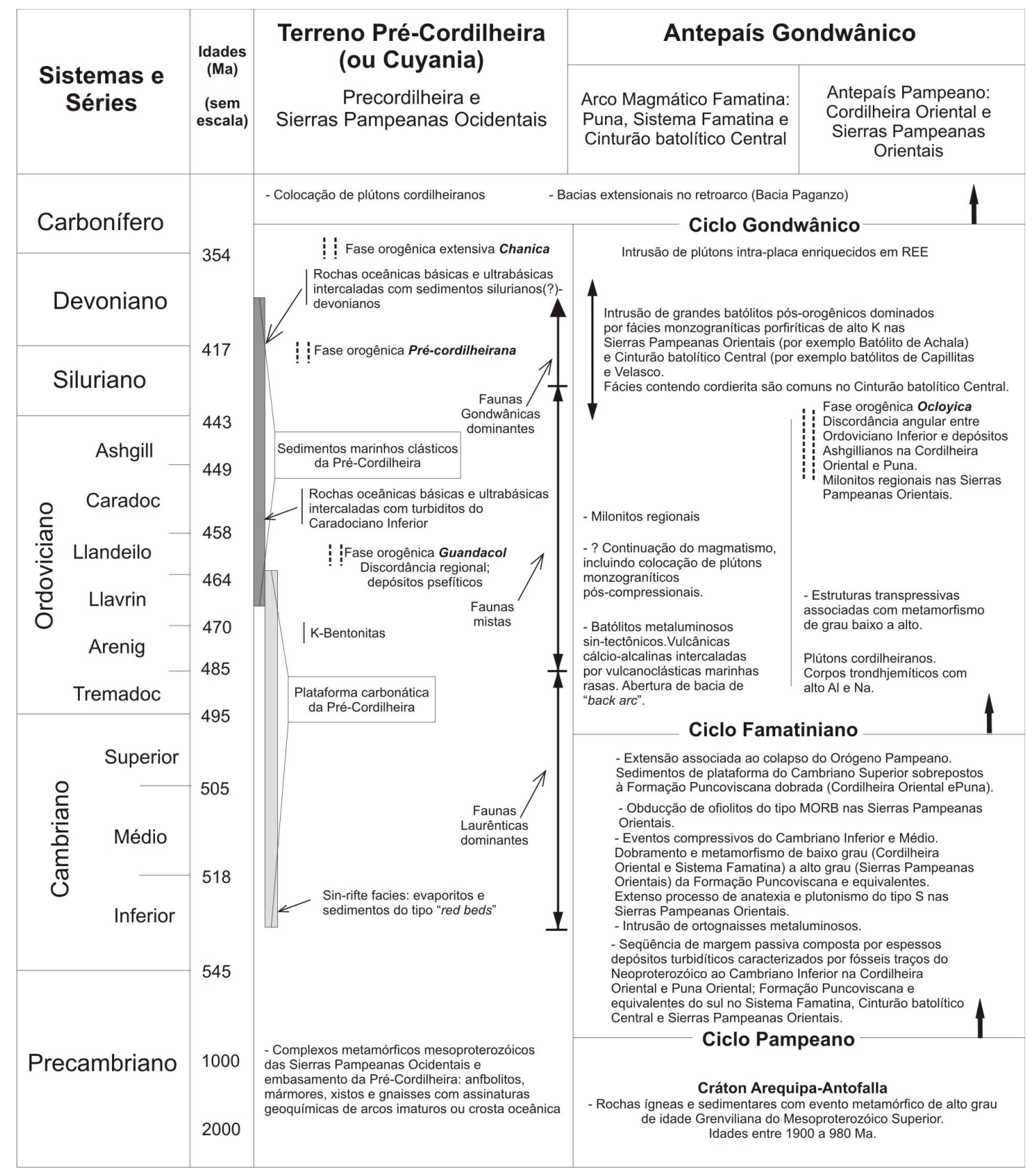


Gilbert et al. (2006) identificaram variações horizontais ao longo das seções sismológicas transversais na crosta do "Pampeam Flat-Slab". Os autores modelaram a litosfera da região, propondo a existência de um nível de crosta inferior eclogitizado e porções da cunha astenosférica serpentinizadas. Os limites de terrenos também foram identificados pelos autores, reforçando assim a idéia de acresção continental de terrenos na protomargem Andina durante o Paleozóico.

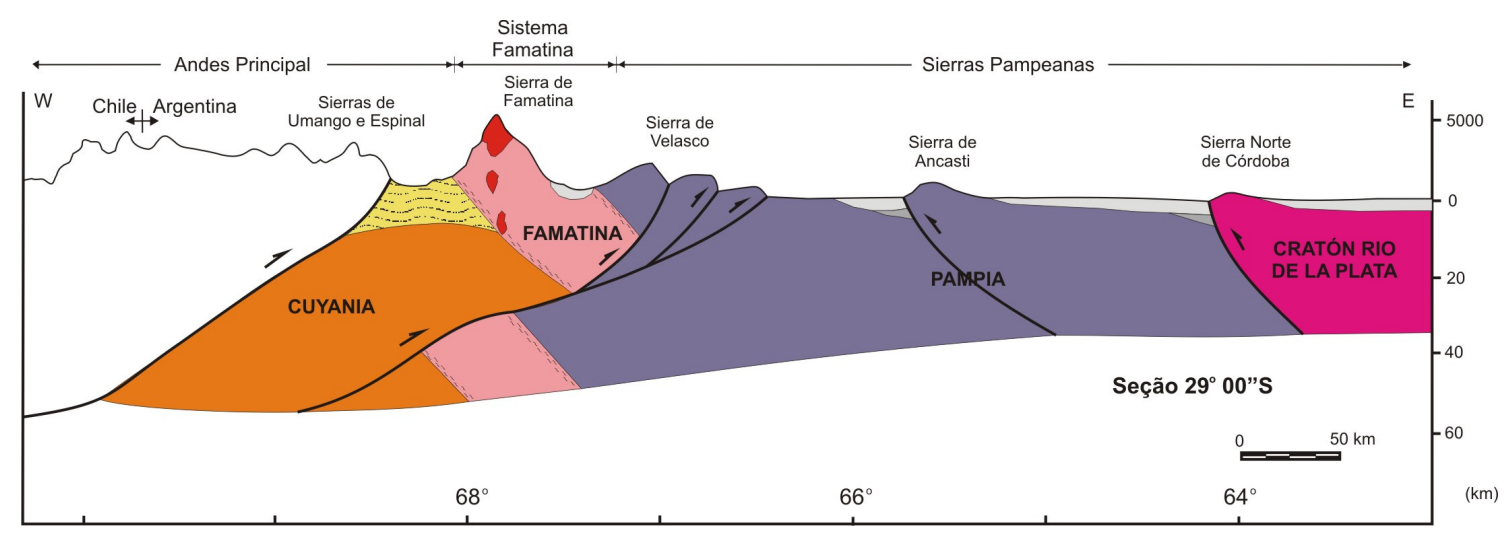

Figura 5: Seção transversal dos Andes Centrais na latitude 2900"S (Modificado de Ramos et al., 2002).

\subsection{Pré-Cordilheira Argentina - Interpretações Geotectônicas}

O conteúdo paleontológico, sua peculiaridade estrutural e geográfica transformaram a Pré-Cordilheira Argentina em uma região chave para o entendimento da evolução dos Andes.

Jordan et al. (1983) foram os primeiros a considerar a subducção de baixo ângulo ("flat subduction") da placa de Nazca sob a placa Sulamericana como causador da deformação de retroarco na região da Pré-Cordilheira. Trabalhos com ênfase na cronologia dos movimentos de falhas (p.e. Jordan et al., 1993) e no encurtamento crustal e estrutura do orógeno Andino (p.e. Allmendinger et al., 1990) descrevem a história tectônica desta região dos Andes, conferindo à Pré-Cordilheira o título de uma das faixas de falhamentos e dobramentos ("fold and thrust belt") mais estudadas do mundo.

A Pré-Cordilheira é uma província geológica alongada N-S localizada entre a Cordilheira Frontal a oeste e Sierras Pampeanas a leste (Figura 6). Consiste em três cinturões longitudinais bem definidos: cinturão leste (Pré-Cordilheira Oriental), consitituído por plataforma carbonática Cambro-Ordoviciana, caracterizada por empurrões para oeste; zona central (Pré-Cordilheira Central), formada pelos blocos paleozóicos Tontal-Tigre-Punilla, compostos principalmente por rochas sedimentares 
clásticas de idade Siluriana a Devoniana; e cinturão oeste (Pré-Cordilheira Ocidental) caracterizado pelo magmatismo basáltico de fundo oceânico (Ordoviciano-Devoniano), seguido por deformação e metamorfismo no Devoniano Médio (Baldis et al., 1984).

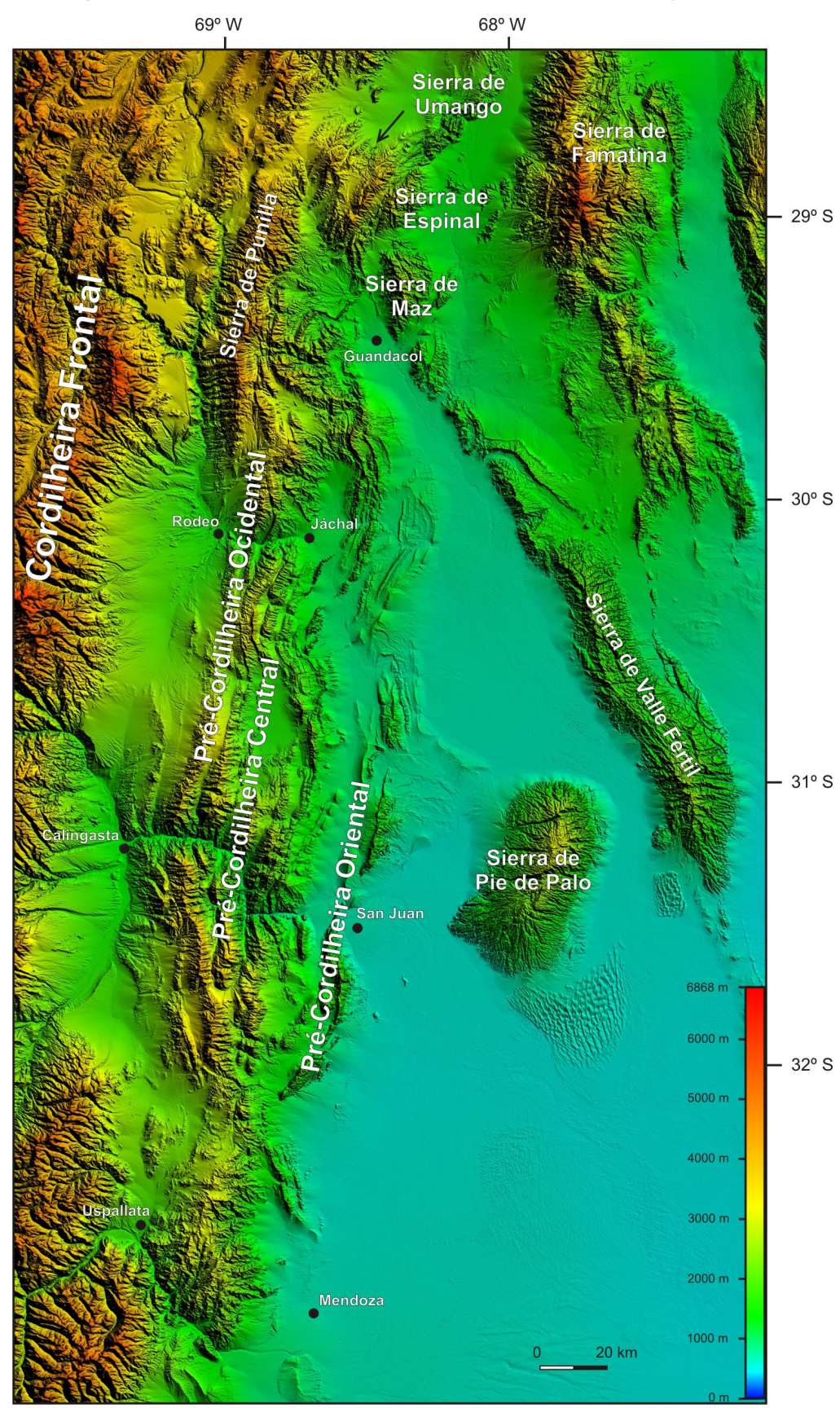

Figura 6: Modelo digital de terreno com a localização geográfica e divisão da Pré-Cordilheira Argentina. Escala de cores corresponde à cota topográfica.

Segundo Baldis et al. (1984), do Cambriano até o limite do Ordoviciano ocorre o desenvolvimento de uma sequência carbonática contínua com características regressivas. O regime de sedimentação algal no limite Cambriano-Ordoviciano seria associado a águas hipersalinas e plataforma tectonicamente estável. No início do Ordoviciano iniciaria um ciclo transgressivo com a desalinização da bacia e relativa 
desestabilização tectônica. Os autores sugeriram uma conexão paleogeográfica entre América do Sul e do Norte, com base nas similaridades sedimentares, faunísticas e tectônicas, durante o Cambro-Ordoviciano.

No Ordoviciano, a bacia estaria segmentada, com deposição de carbonatos principalmente na Pré-Cordilheira Oriental, ocorrência de carbonatos interdigitados por sedimentos clásticos na Pré-Cordilheira Central e deposição essencialmente clástica na Pré-Cordilheira Ocidental (Baldis et al., 1984). De acordo com os autores, a evolução da sequência transgressiva substituiria a deposição de carbonatos por sedimentação de folhelhos negros. Níveis de sedimentação psefítica marcariam episódios tectônicos intra-Ordovicianos (Baldis et al., 1984). Já na Pré-Cordilheira Ocidental, a sequência clástica é dominada por fácies de ambiente profundo intercaladas por lavas basálticas.

Durante o início do Siluriano, rochas ferruginosas foram depositadas em diferentes partes da Pré-Cordilheira (Baldis et al., 1984). Os autores interpretaram essas ocorrências como indicadoras de aquecimento climático na região durante esse período. Indicadores de subsidência rápida na bacia (Pré-Cordilheira Central) e processos regressivos lentos também foram descritos pelos autores supracitados. Sedimentação em regime de águas rasas e plataforma instável caracterizaram o final dos processos regressivos (Baldis et al., 1984).

A bacia no Devoniano foi caracterizada por deposição em plataforma estável e posterior sedimentação de espesso nível de sedimentos terrígenos, compostos por extensos leques submarinos turbidíticos (Baldis et al., 1984).

Um hiato estratigráfico entre o Devoniano Superior e o Carbonífero, identificado por discordância angular em ambos os lados da Pré-Cordilheira, marca o início da sedimentação continental do Grupo Paganzo (Bacia Paganzo) (Baldis et al., 1984).

Com os trabalhos de Von Gosen (Von Gosen, 1992; Von Gosen et al., 1995 e Von Gosen, 1997) três seções clássicas da Pré-Cordilheira Argentina foram descritas com ênfase na evolução estrutural da região.

O transecto pelo Rio San Juan (porção central da Pré-Cordilheira) permitiu Von Gosen (1992) reconhecer importantes características estruturais e tectônicas da região. Um amplo evento de dobramentos, associados à formação de clivagem e metamorfismo de baixo grau, afetaram a seqüência de rochas da Pré-Cordilheira Ocidental após o Siluriano. Falhas normais indicam tectônica extensiva durante 0 Carbonífero Superior na porção leste da seção, permanecendo ativa até o pósTriássico na Pré-Cordilheira Central e Ocidental. Durante o Terciário Superior ocorreu uma fase de tectônica epidérmica ("thin skinned") associada à falhamentos e dobramentos acima de, no mínimo, um "décollement" basal, carreados por 
imbricamentos do tipo "piggy back". O encurtamento crustal E-W de no mínimo 50\% foi acomodado por cavalgamentos antitéticos ("back thrusting"), o que representa a feição estrutural mais importante da margem leste da Pré-Cordilheira.

Von Gosen (1997) observou na Pré-Cordilheira Ocidental a presença de estruturas deformacionais compressivas com metamorfismo de baixo grau associado (bacias ordovicianas e sedimentos de talude). Amplo dobramento com vergência para NW a W, sem claro metamorfismo associado, também foi observado nos depósitos marinhos do Paleozóico Inferior a leste dos sedimentos de fácies de talude. Essa deformação ocorreu após o Devoniano Inferior. As estruturas andinas (compressão do Terciário Superior) aparecem como falhas inversas de transporte para leste, colocando os estratos ocidentais ordovicianos (deformados e metamorfisados) sobre a seqüência clástica do Terciário Superior.

Desde os trabalhos de Astini et al. (1995), Thomas \& Astini (1996), Keller (1999) entre outros, houve certo consenso sobre a origem da Pré-Cordilheira Argentina. Tais trabalhos interpretam a Pré-Cordilheira como um bloco continental exótico, rifteado do supercontinente Laurentia na região da Baía de Ouachita ("Ouachita Embayment") e acrescido à margem ocidental do Gondwana (Figura 4c). A cronologia de ambos os eventos permanece em debate. As interpretações da idade do rifteamento variam do Cambriano Inferior (p.e. Thomas \& Astini, 1996) até o Ordoviciano Médio a Superior (p.e. Keller, 1999) e a idade de acresção varia do Ordoviciano Médio a Superior (p.e. Astini et al., 1995) até o Siluriano/Devoniano (p.e. Keller et al., 1998, Pankhrust \& Rapela, 1998, Rapela et al., 1998 e Keller, 1999).

Considerando o extenso registro sedimentar de um rifte do Cambriano Inferior, Thomas \& Astini (1996) propõem a separação e o isolamento do microcontinente PréCordilheira. A deriva independente do microcontinente pelo Oceano lapetus foi acompanhada de colisão com o arco Famatina na borda oeste de Gondwana (Figura 4c). A deformação silurio-devoniana seria atribuída à colisão do Terreno Chilenia contra a margem oeste da Pré-Cordilheira (Ramos et al., 1986).

Evidências estratigráficas e paleontológicas corroboram com o modelo microcontinental ou de microplaca de afinidade laurentiana ("far-travelled microplate modef'), delineado por Astini, Thomas e colaboradores (Benedetto, 2004). Com a revisão dos dados paleontológicos, estratigráficos e com base nas idéias construídas desde 1993 (p.e. Benedetto, 1993), Benedetto (2004) discutiu de maneira minuciosa as variações de afinidades paleobiogeográficas de braquiópodes, esponjas, trilobitas, ostracodes e bivalves na tentativa de reconstrução paleogeográfica da saga do microcontinente Pré-Cordilheira ao longo do Oceano lapetus do Sul. 
Alternativamente, Keller (1999) interpretou o registro de extensão cambriana como o resultado de estiramento crustal de Laurentia, deixando a plataforma carbonática da Pré-Cordilheira como um platô marginal adjacente à margem de Laurentia. Keller (1999) argumenta que não há estruturas compressivas na PréCordilheira que possam estar relacionadas à colisão ordoviciana, considerando a sucessão sedimentar do Ordoviciano Médio e Superior como evidência de extensão crustal. Outra argumentação utilizada pelo autor que contraria a colisão ordoviciana da Pré-Cordilheira, diz respeito à possibilidade de migração larval por até $3.000 \mathrm{~km}$ nos oceanos e a diferença de faunas de águas mornas a temperadas da Pré-Cordilheira e faunas de águas temperadas a frias do Gondwana no Ordoviciano Médio. Segundo o autor, dados geoquímicos e geocronológicos (Rapela et al., 1998) sugerem que o Cinturão Móvel Famatiniano foi formado por subducção para leste sob o Gondwana, iniciada a aproximadamente $490 \mathrm{Ma}$, persistindo ativa a até $450 \mathrm{Ma}$. As rochas plutônicas do Arco Magmático Famatina foram intrudidas em crosta continental (Sierras Pampeanas Orientais) e apresentam idades de residência crustal Sm-Nd muito próximas as dos plútons cambrianos do seu embasamento, indicando que não houve contaminação de crosta continental de outra placa, contribuindo assim a favor da hipótese de acresção silurio-devoniana da Pré-Cordilheira ao Gondwana (Rapela et al., 1998).

A proposta de modelo geotectônico formulada por Dalziel (1997) apresenta certa similaridade com a hipótese de platô marginal cambriano descrita por Keller (1999). Para Dalziel (1997) a extensão cambriana transferiu a plataforma carbonática da Pré-Cordilheira para um platô marginal adjacente ao supercontinente Laurentia ("Texas Plateau Model'), análogo ao atual platô das Ilhas Falklands-Malvinas no Oceano Atlântico Sul.

Em revisão sobre a história do rifteamento e da acresção da Pré-Cordilheira ao Gondwana, Thomas \& Astini (2003) apresentaram diversas observações que suportam a hipótese do rifteamento cambriano, a acresção ordoviciana do microcontinente PréCordilheira e a acresção do Terreno Chilenia à borda oeste da Pré-Cordilheira durante o Siluriano/Devoniano. As afinidades laurentianas reconhecidas inicialmente na província fisiográfica Pré-Cordilheira (sensu stricto), vêm sendo expandidas geograficamente para as regiões da Serra de Pie de Palo, Ponon Trehue e Cerro San Jorge/Limay Mahuida, onde afloram porções do embasamento e estratos de cobertura do Paleozóico Inferior (Thomas \& Astini, 2003).

Chernicoff et al. (2008) descrevem sedimentos marinhos depositados em bacias de antepaís associadas à docagem do terreno Cuyania, próximo à região do Bloco de San Rafael, à NE de Neuquén. A deformação (dobras e falhas) das rochas 
sedimentares das bacias de antepaís foi ocorrida durante o Devoniano Inferior, relacionado à colisão do terreno Chilenia (Chernicoff et al., 2008).

Em contrapartida, Aceñolanza et al. (2002) discutem a origem alóctone de Cuyania. Para esses autores Cuyania é produto do deslocamento por falhas transcorrentes de uma fatia de plataforma carbonática desenvolvida entre América do Sul, África e Antártica (plataforma SAFRAN). Os autores expõem contradições entre os dados paleomagnéticos e a paleo-posição vinculada ao Laurentia e consideram a hipótese de deslocamento em falhas transcorrentes mais aceitável e fácil para explicar a origem do Terreno Cuyania (Figura 7).
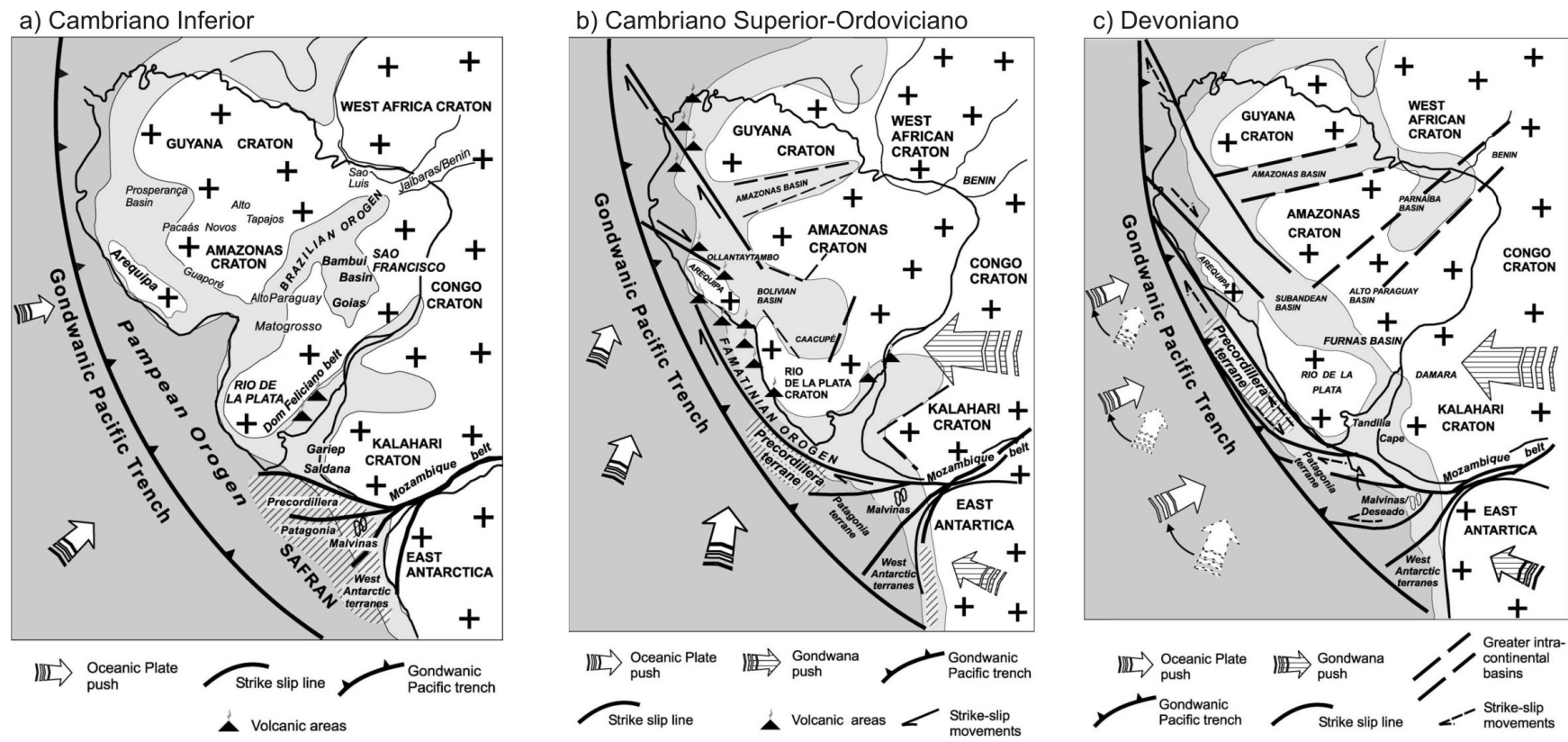

Figura 7: Mapas paleogeográficos do Gondwana Ocidental, com crátons, bacias intracratônicas e orógenos identificados: a) Cambriano Inferior - Microcontinente hipotético SAFRAN situado entre América do Sul, África e Antárctica; b) Cambriano Superior-Ordoviciano - Terreno Pré-Cordilheira começa a percorrer, por forças transpressivas, a borda continental; c) Devoniano - Terreno Pré-Cordilheira é empurrado contra o continente pela rotação da movimentação da placa Proto-Pacífica [Modificado de Acenõlanza et al., (2002)].

Finney et al. (2003) argumentam a favor da história para-autóctone da PréCordilheira em relação à Gondwana. Estudos de proveniência em zircões detríticos levaram os autores a concluir que as rochas da Formação La Cébila, Formação Totora e Formação Las Vacas (Grupo Trapiche) possuem afinidades gondwânicas, com populações de zircões associados aos ciclos Transamazônico/Birminiano, zircões de idades grenvilianas equivalentes de terrenos gondwânicos e populações de zircões característicos dos cinturões orogênicos Brasilianos/Pan-Africanos. 
Em revisão sobre a história geológica de Cuyania, Ramos (2004) apresenta a proposta de terreno exótico ("far-travelled terrane" ou "funeral ship model") como a melhor hipótese para explicar a transferência de Laurentia (Baía de Ouachita) até a margem de Gondwana e todos os fatos paleontológicos e geológicos conhecidos associados a essa transferência. Ramos (2004) descreve ainda os problemas a serem resolvidos, pontuando os limites Norte e Sul do Terreno Composto Cuyania como as principais dúvidas a serem sanadas.

\subsection{Evolução do conhecimento geológico das Sierras Pampeanas} Ocidentais e da Sierra de Umango

As elevações topográficas localizadas no centro-norte da Argentina são denominadas Sierras Pampeanas e chegam a até 6000 metros de altitude acima do nível do mar. São caracterizadas por rochas ígneas e metamórficas de idades que variam do Mesoproterozóico até o Ordoviciano. Correspondem a blocos soerguidos e rotacionados no Cenozóico Superior (Figura 5), associado à tectônica de retroarco compressivo da Cadeia Andina nessa região ("The Pampean Flat-Slab" de Ramos et al., 2002).

As Sierras Pampeanas registraram os diversos ciclos orogênicos que acompanharam toda a história da protomargem Andina. Os principais eventos registrados nessa região foram os ciclos Pampeano (Neoproterozóico Superior ao Cambriano Inferior) e Famatiniano (Cambriano Superior ao Devoniano).

As diferenças de composição do embasamento levaram Caminos (1979) a separar as Pampeanas em Sierras Pampeanas Ocidentais e Sierras Pampeanas Orientais. As Sierras Pampeanas Orientais são caracterizadas por xistos e gnaisses de origem psamo-pelítica e pela abundância de corpos graníticos e migmatitos (Caminos, 1979). As Sierras Pampeanas Ocidentais são distinguíveis pela importante participação de mármores, anfibolitos, rochas ígneas básicas-ultrabásicas e pela escassez de rochas graníticas (Caminos, 1979).

Sato et al. (2000) propuseram a existência de um cinturão N-S de rochas de idade Grenviliana ao longo das Sierras Pampeanas Ocidentais até o Bloco de Las Matras. Os autores consideraram esse cinturão como o embasamento do Terreno Cuyania, composto pelas serras Toro Negro, Umango, Maz e Espinal ao norte, Sierra de La Huerta/Sierra Valle Fértil e Sierra de Pie de Palo na porção central e blocos de San Rafael e Las Matras ao sul (Figura 1). 
As serras de Umango, Maz e Espinal compõem blocos de rochas metaígneas e metassedimentares aflorantes entre as latitudes $28^{\circ} 45^{\prime}$ e $29^{\circ} 30^{\prime} S$ e longitudes $68^{\circ} 45^{\prime}$ e 68 ${ }^{\circ} 15^{\prime} \mathrm{W}$ (Figura 2). Encontram-se limitadas a oeste por rochas sedimentares devonianas (Formação Punilla) pertencentes à Pré-Cordilheira Ocidental, e a leste por rochas graníticas, vulcânicas e sedimentares pertencentes ao Sistema de Famatina.

O reconhecimento geológico pioneiro dessa região é creditado ao trabalho de Hausen (1921). Hausen descreveu na Sierra de Umango um conjunto de rochas supracrustais que denominou Série Pré-Granítica (rochas mais antigas que os granitos do Batólito Famatiniano). Dentro dessa série Hausen identificou rochas metassedimentares e rochas básicas intrusivas (e efusivas?) fortemente deformadas. As rochas metassedimentares foram caracterizadas em três grupos litológicos (calcários, xistos quartzíticos e xistos argilosos), enquanto as rochas básicas foram divididas em sills concordantes de anfibolitos, sill de rocha peridotítica (ocorrência local) e xistos básicos cataclásticos de origem incerta. Para o autor, as rochas descritas teriam idade entre o Cambriano e o Siluriano.

A partir da metade do século passado foi iniciado o mapeamento de cartas geológico-econômicas da República Argentina em escala 1:200.000. A descrição geológica das folhas Villa Union (De Alba, 1954), Vinchina (Turner, 1964) e Cerro La Bolsa (Furqué, 1972) tiveram grande contribuição ao conhecimento geológico da região.

De Alba (1954) separa o embasamento da Sierra de Maz e dos cerros vizinhos à cidade de Villa Union em uma unidade Precambriana, composta por xistos cristalinos em parte migmatíticos, anfibolitos, mármores e filões aplíticos-pegmatíticos. Outra seqüência de rochas mais ou menos metamorfizadas associadas aos granitos e dioritos dos Nevados de Famatina foi reconhecida por De Alba (1954). O autor denominou de Formação Pré-Granítica os quartzo xistos sericíticos, quartzitos com clorita, filitos e quartzo hornfels aflorantes principalmente na porção leste dos Nevados, atribuindo idade pré-ordoviciana ou ordoviciana para ela.

Descrevendo a estrutura da região, De Alba (1954) reconheceu ainda a ação de vários movimentos tectônicos de distinta natureza e idade, ocorridos no Precambriano, Paleozóico Médio, Permotriássico, Terciário (Mioceno) e Terciário Superior-Quaternário.

Turner (1964) considera o embasamento cristalino formado por rochas sedimentares clásticas finas a médias metamorfisadas (Formação Espinal e Negro Peinado) e por rochas graníticas da Formação Guacachico. O autor atribui idade Precambriana para essas unidades. 
A Formação Espinal (seção-tipo localizada no Filo Del Espinal) é caracterizada por xistos micáceos, de variada proporção entre micas e quartzo, e xistos quartzíticos bandados compostos por quartzo, micas e oligoclásio (Turner, 1964). Diques aplíticos e pegmatíticos cortam os xistos da Formação Espinal (Turner, 1964).

Movimentos tectônicos do Precambriano, do Ciclo Caledoniano, do Ciclo Variscano Armoricano e do Ciclo Andino foram descritos por Turner (1964).

Furqué (1972) descreve o embasamento cristalino da porção Sul da Sierra de Umango. O autor distingue xistos quartzo-micáceos, migmatitos, mica xistos, anfibolitos, mármores, rochas filonianas e granitos como as principais variedades litológicas do embasamento e considera as rochas de idade Precambriana.

A descrição das rochas do embasamento e das rochas sedimentares paleozóicas, mesozóicas e cenozóicas, permitiu Furqué (1972) reconhecer quatro eventos de movimentação orogenética na região: Movimentos Precambrianos (afetaram as serras de Umango e Maz), Movimentos Caledonianos (dobraram e fraturaram as rochas ordovicianas), Movimentos Variscanos (afetaram as rochas devonianas) e Movimentos Andinos (afetaram toda a região e imprimiram a fisiografia atual à paisagem).

Os trabalhos de Kilmurray e colaboradores (final da década de 60 e início dos anos 70) descreveram minuciosamente os litotipos encontrados na Sierra de Maz e Cerro Las Ramaditas.

Kilmurray \& Iñiguez Rodriguez (1968) descreveram a presença de gnaisses escapolíticos no Cerro Las Ramaditas, concluindo que as rochas descritas eram derivadas de protólitos calciossilicáticos e foram submetidas a dois estágios de metamorfismo regional, o primeiro de alto grau metamórfico (com as associações piroxênio e anortita ou substituições por escapolita nas rochas calciossilicáticas, e pela isógrada da sillimanita no metapelitos) e o segundo de grau metamórfico mais baixo (marcado por associações de hornblenda, epidoto e talvez granada, além de relictos instáveis de alta temperatura).

Os trabalhos preliminares de Kilmurray (1969), (1970) e (1971) permitiram a identificação de: (a) três zonas de metamorfismo: (i) zona de xistos subdividido em subzonas de xistos cloríticos ou superiores, e xistos muscovíticos-granatíferos ou inferiores; (ii) zona de gnaisses; e (iii) zona de migmatitos e gnaisses de injeção; (b) três fases de deformação: (i) fases 1 e 2 associadas a dobramentos e metamorfismo; e (ii) fase 3 relacionada a falhas; e (c) a divisão do complexo metamórfico da Sierra de Maz e arredores em: (i) Grupo del Taco (caracterizado pela abundância de mármores, quartzitos e gnaisses, incluindo os gnaisses intercalados com mármores e gnaisses calciossilicáticos, migmatitos subordinados e veios de pegmatitos do Cerro Las 
Ramaditas); (ii) Grupo de Maz (caracterizado pela abundância de gnaisses micáceos a quartzo-feldspáticos com intercalações escassas de quartzitos, gnaisses com grafita e migmatitos); e (iii) Grupo del Zaino (integrado por xistos micáceos, alguns com granada e outros com grafita e clorita).

Kilmurray \& Dalla Salda (1971) propuseram a seguinte seqüência de eventos metamórficos e deformacionais para a Sierra de Maz e arredores:

Episódio deformacional (F1): formação de foliação metamórfica penetrativa (S1) e lineações penetrativas (L1) com metamorfismo regional de fácies anfibolito (M1), intrusão de corpos básicos (anfibolitos foliados) e ultrabásicos, e início de migmatização (anatexia). Foi associado ao período Pré-Granítico descrito por Hausen (1921) e considerado pelos autores de idade provável Precambriana;

Episódio deformacional (F2): formação de superfície S2 (plano-axial de dobras de S1) e L2 (lineação mineral e eixos de dobras) sob condições metamórficas na fácies anfibolito inferior (M2), continuação da migmatização e intrusões de corpos básicos pós-F2 (anfibolitos maciços).

Episódio deformacional (F3): formação de superfícies não penetrativas (S3) sob condições de metamorfismo em fácies xisto verde (M3), intrusões de corpos graníticos maiores e menores, metamorfismo de contato e introdução de rochas aplíticas e pegmatíticas.

Os autores consideraram as fases F2 e F3 pertencentes ao período Granítico proposto por Hausen (1921) e sugeriram a idade cambro-ordoviciana para F2 e ordoviciana para F3.

Nas últimas décadas, estudos com ênfase em geoquímica e geocronologia, assim como estudos geotermobarométricos, enriqueceram a discussão geotectônica das rochas das Sierras Pampeanas Ocidentais.

Rochas metavulcânicas localizadas na porção oeste da Sierra de La Huerta (Loma de Las Chacras) foram estudadas por Vujovich et al. (1994). São representadas por anfibolitos, xistos pelíticos, rochas calciossilicáticas e metagreywackes, e correspondem a rochas de afinidade de arco magmático desenvolvido em crosta continental adelgaçada ou crosta oceânica (Vujovich et al., 1994). Os autores interpretam um evento de magmatismo e metamorfismo associado ao prisma acrescionário de idade proterozóica, anterior ao Ciclo Pampeano.

Dados geocronológicos e evidências metamórficas atestam o envolvimento das rochas da Sierra de Pie de Palo no Ciclo Orogênico Famatiniano (Casquet et al., 2001). Zircões separados de rochas metapelíticas cálcicas milonitizadas possuem núcleos zonados de idades grenvilianas (cerca de $1100 \mathrm{Ma}$ ) e sobrecrescimento metamórfico não zonado de idade ordoviciana (cerca de $460 \mathrm{Ma}$ ) (Casquet et al., 
2001). Para os autores, as rochas do embasamento de Pie de Palo sofreram metamorfismo em fácies anfibolito superior de baixa pressão, com anatexia (6,86 \pm 0,4 Kbar e $790 \pm 17^{\circ} \mathrm{C}$ ) comparáveis ao metamorfismo Grenviliano de rochas laurentianas supostamente associadas. O segundo metamorfismo, registrado nas rochas de cobertura, seria de idade famatiniana e regime de alta pressão associado a uma trajetória horária, chegando ao pico bárico em $13 \pm 1 \mathrm{Kbar}$ e $600 \pm 50{ }^{\circ} \mathrm{C}$ (Casquet et al., 2001).

Vujovich \& Kay (1998) interpretaram o Complexo de Pie de Palo como um complexo de arco oceânico/"back-arc" de idade Mesoproterozóica-Grenviliana, similar ao atual complexo da Bacia Lau, no Pacífico Ocidental. A seqüência máfica da região de Las Pirquitas/El Quemado representam a seção basáltica e plutônica de um ofiolito de cadeia da abertura de uma bacia de "back-arc" ("back-arc spreading ridge ophiolite") (Vujovich \& Kay, 1998). As rochas máficas e ultramáficas da Quebrada del Gato e dos Cerros Barboza formam seções ofiolíticas de arco de ilha (Vujovich \& Kay, 1998). Segundo os mesmos autores, os gnaisses de composições intermediárias a ácidas, cálcio-alcalinos e com assinatura de arco, seriam intrusivos na seqüência máfica-ultramáfica da Quebrada del Gato. Consideram ainda que a existência de protólitos de arco juvenil/"back-arc", com cristalização e metamorfismo de idade grenviliana, no Complexo Pie de Palo e no embasamento da Pré-cordilheira suporta a idéia de colisão mesoproterozóica desses terrenos na margem de Laurentia.

Idades $\mathrm{U} / \mathrm{Pb}$ em grãos de titanita, coletados em rochas calciossilicáticas nas regiões de Puna Meridional e Sierras Pampeanas Ocidentais, demonstraram grande intervalo de tempo da permanência de condições de cristalização/recristalização de titanita em altas temperaturas (Lucassen \& Becchio, 2003). Os autores apresentaram idades que variam de Cambriana (entre 530 a $510 \mathrm{Ma}$ ) a Ordoviciana-Siluriana (entre 470 a $420 \mathrm{Ma}$ ). Segundo os autores, esses dados podem ser interpretados como marcadores de um regime de alta temperatura na crosta média de um arco magmático, localizado na margem oeste de Gondwana, do Cambriano ao Siluriano.

Vujovich et al. (2004) apresentaram novas idades mesoproterozóicas (método U/Pb-TIMS em zircão) no Complexo de Pie de Palo, sustentando a existência de um complexo de arco oceânico/"back-arc" a pelo menos 1204 Ma. As idades das bordas metamórficas de zircões ígneos, interceptos inferiores e idades em titanita indicam um importante evento termal durante o Ordoviciano Médio (455-470 Ma) (Vujovich et al., 2004). Zircões detríticos da sequência sedimentar Difunta Corrêa apresentaram idades grenvilianas e idades do Neoproterozóico Superior ( 665 Ma) e são compatíveis com a proveniência laurentiana, contribuindo assim a favor da hipótese de origem laurentiana para Cuyania (Vujovich et al., 2004). Segundo os autores, zircões 
detríticos de idades do Neoproterozóico Superior-Paleozóico Inferior são raros nos sedimentos clásticos laurentianos, porém citam alguns exemplos encontrados nos sedimentos de margem passiva de Laurentia, nos Apalaches. Os autores citam ainda pulsos magmáticos neoproterozóicos em Laurentia, associados a riftes e a quebra de Rodínia, como possíveis fontes para esses zircões.

Maciços anortosíticos de idade de cristalização grenviliana e metamorfismo ordoviciano na Sierra de Maz foram descritos por Casquet et al. (2004). Esses anortositos são comparáveis petrologica e geoquimicamente aos anortositos da Província Grenviliana de Laurentia e sugerem uma extensa província anortosítica no Mesoproterozóico Superior (Casquet et al., 2004).

As rochas metamórficas das serras de Maz e Espinal, "cerros" Las Ramaditas e Asperecitos delimitam um cinturão de orientação NNW-SSE e foram divididos por Casquet et al. (2006) em três domínios paralelos, separados por zonas de cisalhamento de primeira ordem. O Domínio Leste é constituído por granadasillimanita paragnaisses migmatíticos, escassos mármores e anfibolitos. No Domínio Central (ou Domínio Maz) predominam xistos de fácies anfibolito (cianita-sillimanitagranada-estaurolita), quartzitos, anfibolitos e mármores subordinados. No extremo leste do Domínio Central, na Sierra de Maz, ocorre uma seqüência de hornblendabiotita-granada gnaisses e biotita-granada gnaisses com algumas camadas de quartzito e raras lentes de mármore. Relíquias de granulitos máficos e metaperidotitos possuem ocorrência local e as rochas anortosíticas são características deste domínio. Ortognaisses e rochas de um complexo metaplutônico (metadioritos a ortoanfibolitos) são aparentemente mais antigos que os anortositos (Casquet et al., 2006). O Domínio Oeste (grupos El Taco e El Zaino) é caracterizado por duas seqüencias metamórficas de baixo grau: a) Seqüência 1: predominância de granada-clorita xistos com quartzitos subordinados; b) Seqüência 2: dominada por mármores, rochas calciossilicáticas e xistos pelíticos cálcicos, similares à seqüência neoproterozóica Difunta Corrêa da Sierra de Pie de Palo (Casquet et al., 2006).

Os mesmos autores descreveram dois estágios metamórficos em um exemplar de rocha metabásica, atestando um evento metamórfico (M1) de fácies granulito (associação ortopiroxênio-clinopiroxênio-plagioclásio-granada-biotita) e outro evento mais jovem (M2) de fácies anfibolito (associação hornblenda-plagioclásio-granada). Grãos de zircão de um granada xisto foram datados (método U/Pb - SHRIMP), apresentando núcleos com idades paleoproterozóicas (picos aparentes em 1700 e $\sim 1880 \mathrm{Ma}$ ) a mesoproterozóicas, e bordas com idades entre 1180 e $1230 \mathrm{Ma}$ (Casquet et al., 2006). Os autores interpretam que os sedimentos tiveram proveniência de rochas do Paleoproterozóico Superior e sofreram metamorfismo de alto grau na crosta 
inferior a cerca de 1200 Ma. Para os autores o segundo evento metamórfico (M2), registrado nos metabasitos, pode ter ocorrido logo após o evento (M1), correspondendo ao retrometamorfismo causado pela exumação parcial das rochas. Outra alternativa seria a relação de $\mathrm{M} 2 \mathrm{com}$ as bordas de espessura muito fina não datadas (Evento Famatiniano?) (Casquet et al., 2006).

Evidências geocronológicas ( $\mathrm{U} / \mathrm{Pb}$ em zircões detríticos e idades modelo $T_{\mathrm{dm}}$ $\mathrm{Nd}$ ) sugerem idades deposicionais neoproterozóica e/ou paleozóica inferior para as seqüências metassedimentares dos grupos El Taco e El Zaino (Casquet et al., 2008a). Os autores sugerem ainda que o Domínio Maz represente uma seqüência metassedimentar pré-grenviliana, depositada entre 1200 a 1600 Ma. Metamorfismo de fácies granulito Grenviliano e intrusões de rochas ígneas máficas e maciços anortosíticos posteriores afetaram a sequência do Domínio Maz (Casquet et al., 2008a).

Casquet et al. (2008a) interpretam o Domínio Maz como um terreno suspeito similar à porção Norte do Cráton Arequipa-Antofalla. Ambos registram orogênese de idade grenviliana e provavelmente faziam parte de uma faixa contínua ao longo da margem Oeste do Cráton Amazônico (Gondwana Ocidental) (Casquet et al., 2008a).

Rochas carbonatíticas/sieníticas deformadas, com idade de cristalização de cerca de $570 \mathrm{Ma}$, foram descritas por Casquet et al. (2008b). Essas rochas afloram em faixas de até $120 \mathrm{~m}$ de espessura e $4 \mathrm{~km}$ de comprimento, no extremo Nordeste da Sierra de Maz, porção leste do Domínio Maz (Casquet et al., 2008b).

Recentemente, Rapela et al. (2010) discutiram a evolução geotectônica de dois importantes setores das Sierras Pampeanas Ocidentais (Sierra de Maz e Sierra de Pie de Palo/Ullún). Os autores versaram, com base em dados geoquímicos e geocronológicos, sobre a história geológica dos dois setores no Mesoproterozóico. Segundo os autores, as serras de Maz e Pie de Palo/Ullún apresentam evolução geológica com duração de aproximandamente $300 \mathrm{Ma}$.

A Sierra de Maz seria parte de crosta continental durante todo esse período, iniciada como margem continental no Paleoproterozóico, passando para margem continental ativa no Mesoproterozóico vinculada à subducção do tipo Andina, a pelo menos $1330 \mathrm{Ma}$, seguido de evento colisional (entre 1230 e $1170 \mathrm{Ma}$ ) responsável pelo desenvolvimento de metamorfismo de alto grau (Rapela et al., 2010). O final da história mesoproterozóica da Sierra de Maz foi caracterizado por um evento extensional vinculado à intrusão de um complexo intraplaca AMCG (plutonismo com a associação anortosito-mangerito-charnockito-granito) entre 1050 e $1090 \mathrm{Ma}$ (Rapela et al., 2010). 
Entretanto, a Sierra de Pie de Palo/Ullún possui a predominânica de rochas com afinidades de arco oceânico/"back-arc", que representam um sistema completo de arco ativo formado a cerca de 1200 Ma (Rapela et al., 2010). Novos episódios de subducções foram registrados em 1170 e $1110 \mathrm{Ma}$, adquirindo assinaturas de arcos mais maturos (Rapela et al., 2010). Finalmente, os terrenos juvenis acrescidos, agora pertencentes à margem continental, sofreram intrusão de plútons associados à subducção em 1027 Ma (Rapela et al., 2010).

Como em outros terrenos grenvilianos, a história geodinâmica das rochas mesoproterozóicas das Sierras Pampeanas Ocidentais é dominada por tectônica convergente, associada a arcos de margem continental ou intra-oceânicos, com episódios de colisões do tipo arco-continente e eventos extensionais associados à intrusão de complexos AMCG (Rapela et al., 2010).

As rochas do embasamento da Sierra de Umango foram descritas por Varela et al. (1996). O trabalho citado focou na descrição e geocronologia dos Granitóides Los Guandacolinos e dos Gnaisses Quebrada de Juchi. Os granitóides foram caracterizados pelos autores como granodioritos e monzogranitos de texturas porfiríticas de granulação fina a equigranulares. Os autores citaram estruturas de fluxo ígneo e também zonas discretas de deformação milonítica pós-cristalização. Gnaisses de composições principalmente graníticas (Gnaisses Quebrada de Juchi) estão associados a rochas máficas, que representariam lavas basálticas metamorfisadas em condições de alta pressão, provavelmente na transição para a fácies eclogito (Varela et al., 1996). Os mesmos autores descreveram gnaisses em fácies anfibolito a granulito. Os estudos geocronológicos assinalaram idades (isócrona $\mathrm{Rb} / \mathrm{Sr}$ ) de $1030 \pm$ 30 Ma para os Gnaisses Quebrada de Juchi e de $352 \pm 14$ Ma para os Granitóides Los Guandacolinos (Varela et al., 1996).

Os trabalhos posteriores de Varela e colaboradores (Varela et al., 2000, 2001, 2002, 2003a, 2003b, 2005 e 2008) focaram no desenvolvimento da história geodinâmica da Sierra de Umango, utilizando geologia de campo, geoquímica e geocronologia.

Uma unidade de rochas graníticas deformadas que aflora no sudeste da Sierra de Umango foi denominada Granito El Peñon por Varela et al. (2000). Essa unidade é composta por granitos biotíticos (ortognaisses graníticos), pegmatóides graníticos e granodioríticos e escassos granodioritos deformados, caracterizados principalmente por uma foliação bem definida (Varela et al., 2000). Sua idade de $469 \pm 9 \mathrm{Ma}$ (isócrona $\mathrm{Rb} / \mathrm{Sr}$ ) foi atribuída à deformação e metamorfismo que afetam os granitóides com origem em níveis crustais superiores (Varela et al., 2000). 
Varela et al. (2001) utilizaram isótopos de Sr, C e O para estimar a idade de sedimentação dos mármores pertencentes à Sierra de Umango. Segundo os autores a assinatura isotópica de $\mathrm{Sr}$ e $\mathrm{C}$ sugerem idade neoproterozóica para a sedimentação da seqüência carbonática/siliciclástica da Sierra de Umango, assinalada entre 640 e 580 Ma pela razão ${ }^{87} \mathrm{Sr} /{ }^{86} \mathrm{Sr}$.

Dois estágios metamórficos foram reconhecidos por Varela et al. (2002). O metamorfismo (M1) corresponde à fácies anfibolito alto e gerou uma foliação $\mathrm{S} 1$ enquanto o metamorfismo (M2) associa-se ao retrometamorfismo do anterior em fácies xisto verde, produzindo zonas de cisalhamento e foliação milonítica S2 (Varela et al., 2002). Dados radiométricos sugerem que a milonitização de leucopegmatóides e a re-homogenização isotópica $\mathrm{Sm} / \mathrm{Nd}$ de fases minerais em anfibolitos ocorreram entre 373 e 392 Ma (Devoniano Médio), indicando a idade do metamorfismo (M2) (Varela et al., 2002).

A idade de cristalização obtida para os protólitos ígneos nos ortognaisses Juchi foi de $1108 \pm 13 \mathrm{Ma}$ (U/Pb-TIMS em zircão) (Varela et al., 2003a). As idades de isócrona $\mathrm{Rb}$-Sr de $1030 \pm 30$ Ma foram interpretadas como idade de metamorfismo por Varela et al. (1996). Segundo Varela et al. (2003a), a relação ${ }^{87} \mathrm{Sr} /{ }^{86} \mathrm{Sr}(0,7026 \pm$ 0,0003 ) e os valores de idade modelo $T_{\mathrm{dm}} \mathrm{Sm}-\mathrm{Nd}$ (1485 a $\left.1447 \mathrm{Ma}\right)$ indicam materiais juvenis mesoproterozóicos.

Os dados radiométricos mais atualizados do Granito El Peñon registram $473 \pm$ $17 \mathrm{Ma}$ (U/Pb-TIMS em zircão). Desta forma, os resultados $\mathrm{Rb} / \mathrm{Sr}$ anteriores (469 \pm 9 Ma) com $\left({ }^{87} \mathrm{Sr} /{ }^{86} \mathrm{Sr}=0,7110 \pm 0,0002\right)$ foram interpretados como idade de metamorfismo, sugerindo para esse granito uma origem sintectônica, gerado por fusão parcial de material crustal (Varela et al., 2003a). Os autores interpretaram a ambientação tectônica relacionada à tectônica colisional, com estruturas vergentes para oeste associadas a importantes cavalgamentos do interior do orógeno para seu antepaís.

Varela et al. (2003a) reforçaram a existência de nova fase deformacional e metamorfismo devoniano, seguido de granitogênese tardi-orogênese Famatiniana (Granito Los Guandacolinos) e granitogênese Gondwânica (Granito Cerro Veladero). O Granito Los Guandacolinos foi descrito como intrusivo com presença de faixas discretas de deformação milonítica, enquanto o Granito Cerro Veladero é isotrópico de tendência sub-alcalina (Varela et al., 2003a).

Idades em zircão de duas amostras da Unidade Ortognaisses Juchi confirmaram as idades de cristalização dos protólitos no Mesoproterozóico (1216 \pm 29 e $1090 \pm 30 \mathrm{Ma}$ ) (Varela et al., 2003b). Cristais de zircão coletados em biotita gnaisse definiram uma discórdia (U/Pb) com intercepto superior em $1139 \pm 82 \mathrm{Ma}$ e intercepto 
inferior em $447 \pm 36 \mathrm{Ma}$ (Varela et al., 2003b). Os autores interpretaram o intercepto superior como idade de herança do embasamento Grenviliano e o intecepto inferior como idade de metamorfismo.

Datações $\mathrm{U} / \mathrm{Pb}$ em frações de monazita coletadas em paragnaisse milonítico forneceram idade de $452 \pm 6 \mathrm{Ma}$ (Varela et al., 2003b). Para os autores, esse dado confirma a idade do metamorfismo registrada no biotita gnaisse.

Novos dados geocronológicos para o Granito Los Guandacolinos foram apresentados por Varela et al., 2005. Os dados $\mathrm{Rb} / \mathrm{Sr}$ mostraram uma errócrona de $324 \pm 36 \mathrm{Ma}$ e a média das idades U/Pb forneceu uma idade de $314 \pm 14 \mathrm{Ma}$ (Varela et al., 2000). A idade U/Pb (314 $\pm 14 \mathrm{Ma}$ ) foi interpretada pelos autores como a idade de cristalização e representaria o menor valor disponível para fixar o tempo de intrusão do Granito Los Guandacolinos.

González et al. (2005) descreveram uma trajetória metamórfica horária para rochas máficas da região do Cerro Cacho. Relíquias de associações de fácies eclogito $\left(\mathrm{M}_{1}\right)$ (granada granoblástica sem inclusões de plagioclásio + diopsídio + ilmenita + rutilo), associações de pico metamórfico em fácies granulito $\left(\mathrm{M}_{2}\right)(P=12-14 \mathrm{Kbar}$ e $\left.\mathrm{T}=731-853{ }^{\circ} \mathrm{C}\right)$ e retrometamorfismo em fácies anfibolito $\left(\mathrm{M}_{3}\right)$ e posteriormente em fácies xisto verde $\left(\mathrm{M}_{4}\right)$ foram caracterizados pelos estudos petrográficos e geotermobarométricos (González et al., 2005).

Os autores supracitados consideram $M_{1}$ e $M_{2}$ associados à principal fase orogenética da Orogênese Famatiniana (Ordoviciano Inferior) e $\mathrm{M}_{4}$ ao metamorfismo de zonas de cisalhamento (idades $\mathrm{Rb} / \mathrm{Sr}$ e $\mathrm{K} / \mathrm{Ar}$ de 390-370 Ma) vinculado à formação de foliação milonítica e bandas de cisalhamento S/C.

Duas novas unidades geológicas foram propostas por Varela et al. (2008) para a Sierra de Umango. A unidade Tambillito foi caracterizada por filitos, xistos e anfibolitos com ausência de mármores. A idade $\mathrm{U} / \mathrm{Pb}$ em zircão de rocha anfibolítca dessa sequência indicou um intercepto superior em $1108 \pm 4 \mathrm{Ma}$. Os autores consideraram essa informação como sendo a idade de intrusão e cristalização dos diques básicos, porém não descartam a possibilidade dos zircões serem xenocristais capturados da rocha encaixante.

A unidade El Cordobés foi descrita como uma faixa de metagabros e anfibolitos que intrudiram a sequência Tambillo (Varela et al., 2008). Dados U/Pb em zircão demonstraram uma idade de $446 \pm 3 \mathrm{Ma}$, um pouco mais velha que a idade em isócrona $\mathrm{Rb}-\mathrm{Sr}$ (rocha total, feldspato e anfibólio) de $392 \pm 50$ publicada anteriormente (Varela et al., 2002) e foram consideradas, conjuntamente com o enxame de pegmatitos expostos no perfil do Rio Umango, pertencentes à tectônica extensional Chanica (Varela et al., 2008) (ver Tabela 2). 
Uma nova unidade, não descrita por Varela et al., 2008, foi reconhecida, neste trabalho, à oeste do Puesto Los Guandacolinos. Trata-se de estreita fatia composta por filitos e rochas carbonáticas metamorfisadas em baixo grau, possivelmente correlacionável aos carbonatos e siltitos cambro-ordovicianos da Pré-Cordilheira.

Tentativamente, Vujovich et al. (2001) posicionaram as serras de Maz, Espinal e Ramaditas na margem ocidental do Terreno Pampia (ou Sistema de Famatina) ou na margem sudoeste de Gondwana, e consideraram correlacionáveis com as unidades similares das serras de Chepes e San Luis, e com a formação Puncoviscana aflorante no noroeste da Argentina. Os autores consideraram ainda a Sierra de Umango como parte do embasamento do Terreno Composto Cuyania. Os mesmos autores adotaram as unidades litológicas propostas por Kilmurray \& Dalla Salda (1971), substituindo o termo Grupo por Complexo.

Utilizando uma abordagem multidisciplinar, Porcher et al. (2004) reconheceram nas serras de Maz, Espinal, Ramaditas e Umango diversos episódios de acresção crustal, metamorfismo e deformação, desde o Proterozóico Inferior ao Carbonífero. Os estudos termobarométricos, geocronológicos $(\mathrm{Sm} / \mathrm{Nd})$ e geofísicos permitiram aos autores propor possibilidades de locação da sutura entre o Terreno Cuyania e a borda oeste da protomargem andina do Gondwana.

Os dados isotópicos apresentados por Porcher et al. (2004) sugerem que a sutura entre Cuyania e Gondwana poderia ser traçada entre as serras de Umango e Maz/Espinal, coincidente com o lineamento regional NNE, restrito a níveis rasos da crosta. Por outro lado, as evidências geofísicas sugerem que a sutura poderia ser delineada a leste das serras de Maz e Espinal, no lineamento do Valle Fértil (Porcher et al., 2004).

\section{GEOLOGIA DA SIERRA DE UMANGO}

A seguir serão apresentados os dados obtidos nessa dissertação de mestrado. Os subcapítulos que seguem dizem respeito às unidades litoestratigráficas e tectônicas da Sierra de Umango, a análise estrutural e algumas feições microestruturais características das rochas estudadas.

\subsection{Unidades Litoestratigráficas e Tectônicas}

A descrição detalhada das unidades geológicas mapeadas e suas relações de contato buscam o entendimento dos eventos deformacionais, metamórficos e magmáticos que afetaram as rochas da região. A figura 8 apresenta o mapa geológico 
da Sierra de Umango. Devido ao clima árido da região, as rochas apresentam baixo grau de intemperismo químico, porém possuem marcante fraturamento, observado na maioria dos afloramentos visitados.

Este trabalho utilizou a nomenclatura de unidades geológicas para a Sierra de Umango sumarizadas no trabalho de Varela et al. (2008). Para as unidades entorno à serra, utilizou-se os limites geológicos e a nomenclatura apresentada por Kilmurray \& Dalla Salda (1971) e Casquet et al. (2008a) para as rochas das serras de Maz e Espinal, e Caminos \& Fauqué (1999) e Fauqué et al. (2004) para as rochas mesozóicas e cenozóicas.

As unidades mapeadas incluem os Ortognaisses Juchi, as unidades metassedimentares Tambillo e Tambillito, os granitos El Peñon, Los Guandacolinos e Cerro Veladero, a unidade de rochas metabásicas El Cordobés e a seqüência carbonática La Troya.

\subsubsection{Ortognaisses Juchi}

A unidade de embasamento na Sierra de Umango corresponde aos Ortognaisses Juchi. São compostos principalmente por hornblenda-biotita gnaisses tonalíticos, biotita gnaisses granodioríticos, metatexitos caracterizados por leucossoma throndjemítico de granulação fina, melanossoma composto principalmente por biotita e hornblenda e mesossoma com cerca de $20 \%$ de máficos. Bandas de rochas metabásicas, de espessuras centimétricas a decimétricas, localmente com granada e clinopiroxênio (Prancha I - Fotos 1, 2, 3, 4 e 5) ocorrem intercaladas aos gnaisses. Rochas retroeclogíticas a granulíticas de alta pressão são descritas intercaladas, como boudins ou bandas de espessura métrica, em biotita gnaisses na região da Água de La Falda, noroeste da Sierra de Umango (Prancha I - Foto 6) (González et al., 2005). Bandas de biotita gnaisses sienograníticos vermelho-rosadas, hololeucocráticas, espessas de alguns metros a dezenas de centímetros, também são comuns, freqüentemente com estrutura milonítica. Veios sienograníticos, com dezenas a poucos centímetros de espessura, foram introduzidos no pacote gnáissico e encontram-se deformados.

Os Ortognaisses Juchi ocorrem preservados em estruturas sinformais sobre a seqüência metassedimentar Tambillo. São interpretados como klippen no centro-sul (Quebrada Juchi) e no noroeste (Água de La Falda) da serra. As estruturas reconhecidas nessas rochas serão descritas nos capítulos seguintes. 


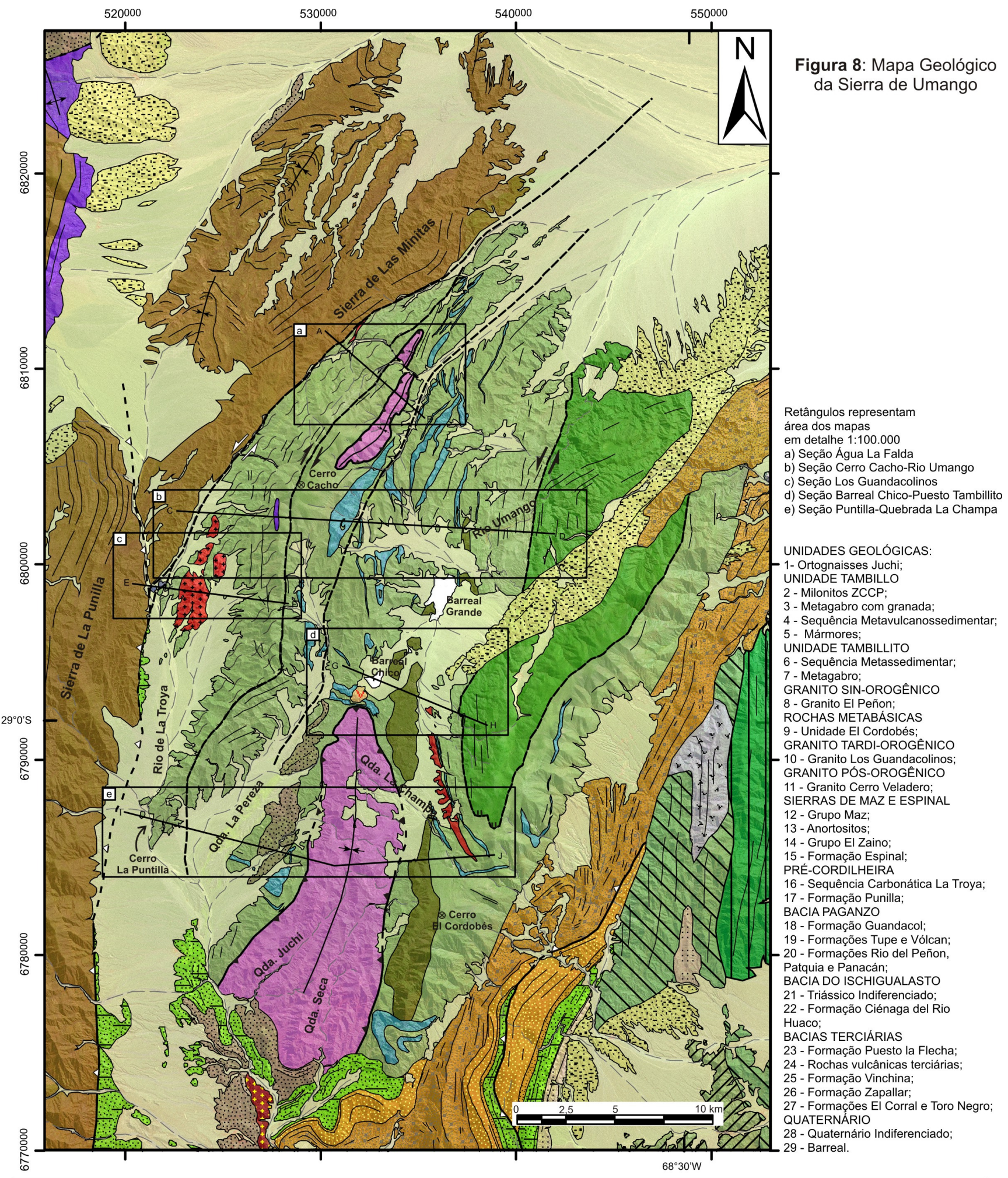

\begin{tabular}{|c|c|c|c|c|c|c|c|c|}
\hline \multirow[t]{3}{*}{ 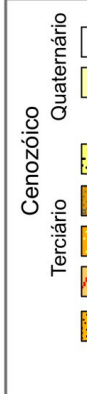 } & \multirow[t]{3}{*}{ 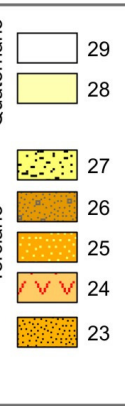 } & \multirow{3}{*}{ 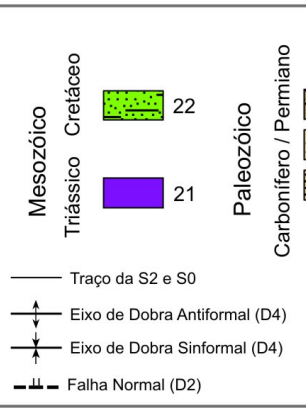 } & \multirow{3}{*}{ 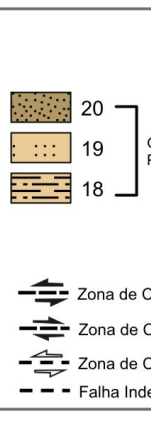 } & \multirow{3}{*}{\multicolumn{2}{|c|}{ 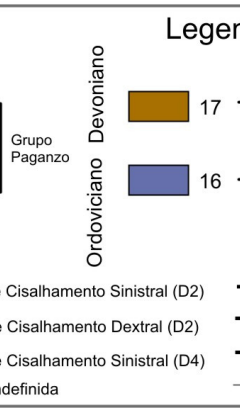 }} & $\begin{array}{l}\text { nda } \\
7 \text { Precordilheira }\end{array}$ & $\begin{array}{l}\text { Sierras de Maz e Espinal } \\
\qquad \begin{array}{l}15 \\
\square \square_{14}^{14} \\
\square \square_{12}^{13}\end{array}\end{array}$ & $\begin{array}{l}\text { Sierra de Umango } \\
\text { Carbonifero } \\
\text { Siluriano } \\
\text { Ordoviciano } \\
\text { Sedimentacăo de idade desconhecida } \\
\text { Metamorismo ordoviciano } \\
\text { Unidade Tambilito } \\
\\
\text { Unidade Tambillo }\end{array}$ \\
\hline & & & & & & . & & \\
\hline & & & & & & & & \\
\hline
\end{tabular}


As regiões visitadas dessa unidade correspondem às seções de Quebrada Juchi, Água Amarilla, Quebrada La Champa e Água La Falda. Um maior detalhamento geológico-estrutural, acompanhado por estudos petrológicos, geoquímicos e petrogenéticos são indispensáveis para o melhor entendimento da evolução geológica dessas rochas ortoderivadas, principalmente em relação à história pré-ordoviciana.

O contato oeste dessa unidade foi observado na seção da Água Amarilla e o contato leste encontra-se coberto pelos depósitos cenozóicos na Quebrada La Champa. A sul, os Ortognaisses Juchi encontram-se sob as rochas sedimentares do Paleozóico Superior e do Cretáceo.

Nas lâminas delgadas de rochas gnáissicas foi possível observar rochas bandadas e rochas foliadas, com microbandamento granoblástico e nematoblástico (Prancha II - Fotos 7 e 8). Em gnaisses biotíticos, o microbandamento intercala bandas granoblásticas e lepidoblásticas. Texturas miloníticas a protomiloníticas são frequentes. A granulação varia de fina a média, com conteúdo mineralógico principal caracterizado por hornblenda, quartzo, plagioclásio, feldspato $\mathrm{K}$, granada, biotita, opacos e, localmente, clinopiroxênio e minerias do grupo do epidoto.

As lâminas delgadas de rochas metamáficas, provenientes de boudins em meio às rochas gnáissicas da Água La Falda, foram descritas como granada-clinopiroxênioquartzo anfibolitos com rutilo, titanita e opacos, variando de estrutura maciça a foliada, de textura granonematoblástica e granulação fina a média (Prancha II - Fotos 9 e 10).

As associações minerais observadas sugerem condições de metamorfismo de alto grau, em fácies granulito de regime de média a alta pressão.

\subsubsection{Unidades Metassedimentares}

Duas seqüências metassedimentares denominadas Tambillo e Tambillito foram identificadas na Sierra de Umango. A relação estratigráfica e cronológica entre as duas unidades segue incerta.

Mapeamento geológico-estratigráfico de detalhe e extensivo estudo de proveniência fazem-se necessários para embasar as idéias e interpretações da história geológica dessas seqüências.

\subsubsection{Unidade Tambillo}

A Unidade Tambillo aflora na maior parte da serra, principalmente na porção central e oeste. Possui uma espessa faixa de cisalhamento em seu extremo oeste e diferenças litológicas notáveis entre a porção oeste e leste da unidade. 


\section{Prancha I}
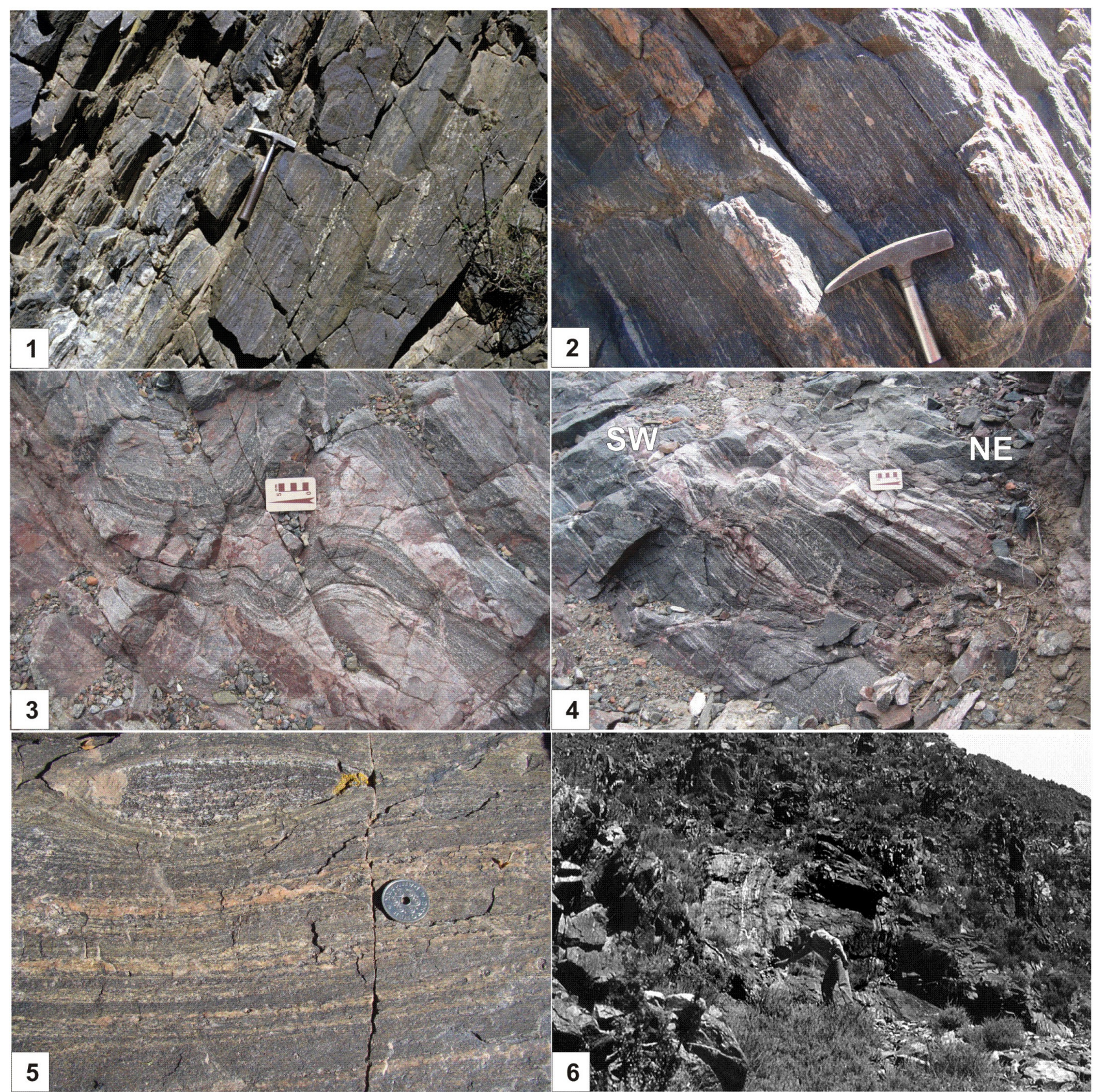

Foto 1: Sequência de biotita gnaisses bandados, protomiloníticos. Notar dobra intrafolial à direita do martelo. Ponto UM509.

Foto 2: Detalhe de bandas róseas de granulação grossa (pegmatóides deformados) e bandas miloníticas com sigmóides (ocelos) quartzo-feldspaticos. Ponto UM804.

Foto 3: Bandamento gnaissico (S2) caracterizado pela intercalação de bandas de coloração cinza (composição granodiorítica) e bandas de coloração rósea (composição sienogranítica). O bandamento gnaissico encontra-se dobrado por dobras assimétricas e inclinadas pós-D2 (possivelmente D3) vergentes W. UM415.

Foto 4: Hornblenda-biotita gnaisses bandados com boudin de rocha metabásica e dobras surreicas destacadas por vênulas estromáticas de sienogranito hololeucocrático. Ponto UM415.

Foto 5: Boudin de rocha metabásica (granada anfibolito) em meio a biotita gnaisse migmatítico de composição granítica. Ponto UM806.

Foto 6: Extensos boudins de rocha metabásica (incluindo anfibolitos com clinopiroxênio) intercalados em biotita gnaisses milonitizados. Quebrada Água La Falda - Ponto UM533. 


\section{Prancha II}

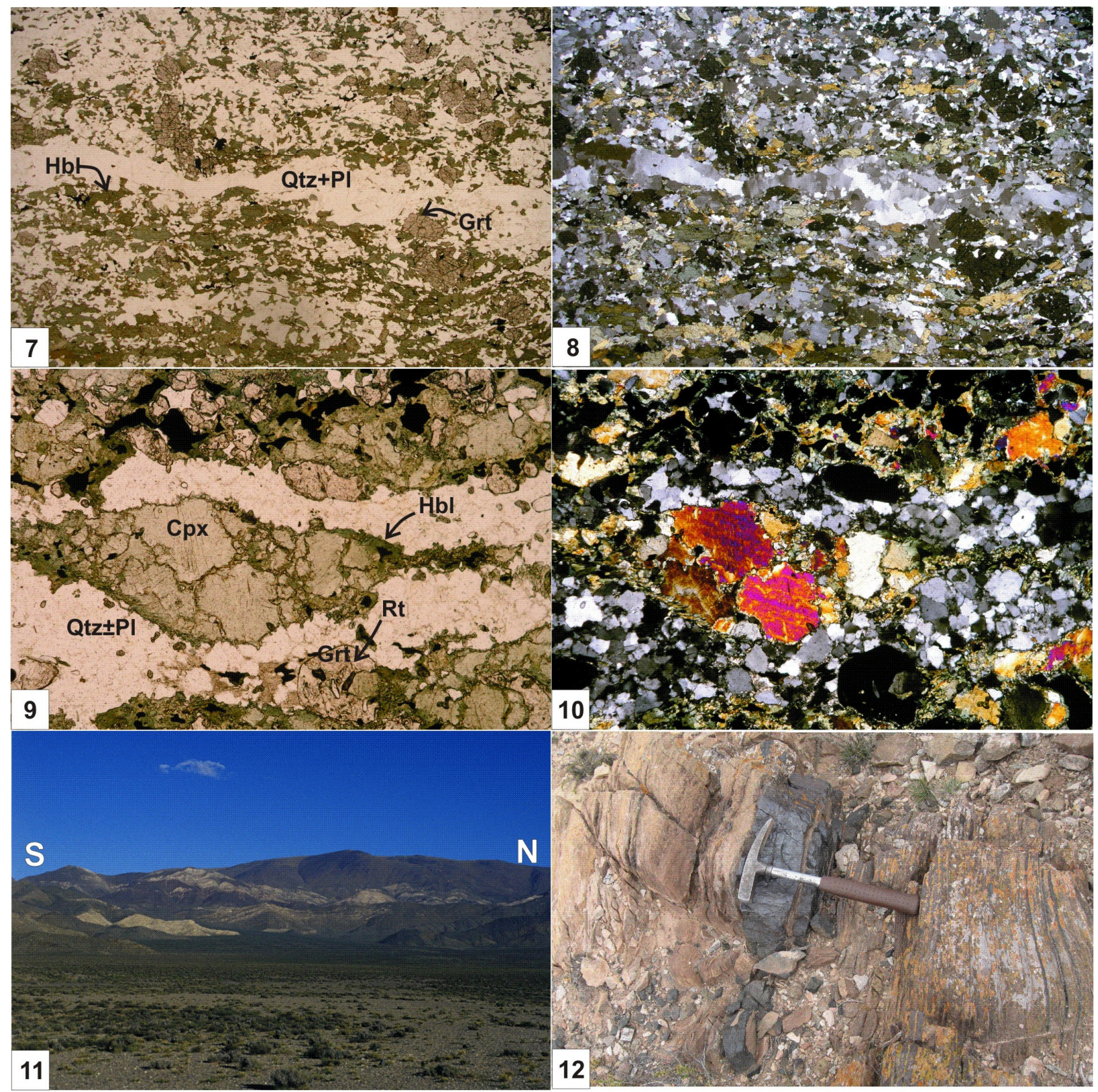

Foto 7: Fotomicrogrfia de estrutura geral bandada (S2) de granada-hornblenda gnaisse com opacos e biotita. Ortognaisses Juchi, Amostra UM805. Foto com nicóis paralelos e lado maior igual a 10,2 mm.

Foto 8: Idem à foto 7 com analisador inserido.

Foto 9: Fotomicrografia de granada-clinopiroxênio-quartzo anfibolito, bandado. Granada apresenta-se

sub a idioblástica com inclusão de rutilo, quartzo e plagioclásio ocorrem granoblásticos em bandas irregulares lenticulares, e hornblenda aparece nas bordas dos cristais de clinopiroxênio, frequentemente associada a opacos. Ortognaisses Juchi, Amostra UM533F. Foto com nicóis paralelos e lado maior igual a $5,1 \mathrm{~mm}$.

Foto 10: Idem à foto 9 com analisador inserido.

Foto 11: Aspecto geral dos bancos espessos de mármore aflorantes na face leste do Cerro Cacho.

Foto 12: Intercalações boudinadas de anfibolito em meio ao mármore. Ponto UM702. 
A região oeste é caracterizada por bancos de mármores de espessuras variando de dezenas a até centenas de metros (mapeáveis nas imagens de satélite) intercalados por camadas de espessura métrica de anfibolitos e de rochas calciossilicáticas, e xistos feldspáticos (metagrauvacas?) (Prancha II - Fotos 11 e 12; Prancha III - Foto 13).

$\mathrm{Na}$ região leste predominam intercalações de biotita-muscovita xistos, biotitamuscovita-quartzo xistos, quartzitos, rochas calciossilicáticas, anfibolitos, e as camadas de mármore são subordinadas (Prancha II - Fotos 14, 15, 16 e 17). Ainda na porção leste da unidade, no perfil do Rio Umango, ocorrem freqüentes leitos de pegmatitos paralelos à foliação principal, assim como em veios discordantes (Prancha III - Fotos 16 e 18). Pequeno corpo de biotita granito leucocrático equigranular, fanerítico médio-grosso, com cerca de 10 metros de diâmetro de exposição, aflora no perfil do Rio Umango.

No limite oeste da Unidade Tambillo há espessa zona de cisalhamento (com cerca de $4 \mathrm{~km}$ de espessura aparente e mais de $38 \mathrm{~km}$ de extensão), orientada NNE, denominada nesse trabalho de Zona de Cisalhamento Cerro Cacho-Puntilla (ZCCP). Corresponde a Unidade Tambillo milonitizada, dominada por intercalações de aluminossilicato-granada-plagioclásio-quartzo-biotita milonito, mármores brechados e boudins anfibolíticos (Prancha IV - Fotos 19, 20, 21, 22 e 23). Bandas de granito milonítico cinza porfiroclástico e ultramilonitos cinza escuro aparecem com freqüência (Prancha IV - Foto 24). No Cerro Cacho ocorre, a $4000 \mathrm{~m}$ de altitude, um corpo tabular de rocha metadiorítica/metagabróica com granada, aparentemente intrusivo na zona de contato da faixa milonítica (Prancha V - Fotos 25 e 26).

Rochas sedimentares do Devoniano (Formação La Punilla) e uma fatia tectônica de rochas carbonáticas e filíticas (Sequencia Carbonática La Troya) estão em contato por falhas à oeste dessa unidade. A leste, o contato dá-se por falhas com a Unidade Tambillito, o qual será discutido em seguida.

Os xistos micáceos descritos em lâminas delgadas demonstram estrutura foliada/xistosa, freqüentemente com bandas irregulares félsicas ricas em quartzo e plagioclásio. A textura varia de granolepidoblática a lepidogranoblástica com granulação média a fina-média. Quartzo, plagioclásio, biotita, muscovita e granada são os minerais principais desses litotipos (Prancha V - Fotos 27 e 28).

Muscovita-biotita quartzitos com granada, lepidogranoblásticos de granulação fina também foram descritos nessa unidade.

Os xistos feldspáticos apresentam estrutura foliada definida por bandas de textura nematolepidoblástica (ricas em biotita, cianita e sillimanita) e bandas de espessura submilimétricas granoblásticas (ricas em quartzo e plagioclásio) com 
granulação fina. Ocorrem freqüentes porfiroclastos de plagioclásio e feldspato $K$, assim como porfiroblastos de granada deformados.

As rochas calciossilicáticas, por sua vez, possuem estrutura foliada a finamente bandada, textura granoblástica, compostas principalmente por quartzo, carbonato, minerais do grupo do epidoto, titanita e anfibólio, ocorrendo também granada (Prancha V - Fotos 29 e 30).

Anfibolitos quartzosos com rutilo apresentam estrutura foliada, textura característica nematoblástica e granulação fina-média.

As rochas pertencentes à ZCCP possuem marcante estrutura foliada e textura protomilonítica a milonítica, definida principalmente por bandas lepidoblásticas ricas em biotita de granulação fina, fitas de quartzo e porfiroclastos deformados de feldspato e granada (Prancha VI - Fotos 31, 32, 33, 34, 35 e 36; Prancha VII - Fotos 37 e 38).

As condições metamórficas estimadas para essa unidade variam da fácies anfibolito superior de alta pressão, em presença de muscovita, e ultrapassando as reações de quebra da muscovita com geração de feldspato potássico em presença de aluminossilicato.

Estudos sistemáticos da variação das condições de metamorfismo ao longo da Unidade Tambillo são imprescindíveis para o melhor entendimento dos processos tectono-metamórficos que afetaram essas rochas.

\subsubsection{Unidade Tambillito}

A Unidade Tambillito corresponde a uma sequência siliciclástica pelitopsamítica metamorfisada, aflorante na porção leste da Serra de Umango. Caracterizam-se pela intercalação de camadas métricas a submétricas de muscovitaclorita xistos com estaurolita, muscovita-biotita xistos com granada, quartzitos impuros com granada, quartzitos bandados (metachert?) e subordinadamente anfibólio xistos a anfibolitos. No contato entre as unidades Tambillo e Tambillito, na localidade do Puesto Tambillito, ocorre corpo tabular e lenticular de metagabro de granulação grossa.

Foi descrita apenas na seção do Puesto Tambillito (Prancha VII - Foto 39) e no extremo leste da seção do Rio Umango, sendo a unidade que mais necessita de detalhamento. O delineamento dos contatos sul e leste foram feitos com a interpretação das imagens de satélite. A checagem desse contato faz-se necessário.

O contato entre as unidades Tambillo e Tambillito é tectônico, definido por falha dobrada e com alto ângulo de mergulho. A interpretação geológica e os dados obtidos 
sugerem que essa unidade ocorra em uma sinforma normal com aproximadamente 5 km de meio comprimento de onda (ver discussão em Análise Estrutural).

As descrições de lâminas delgadas propiciaram um maior detalhamento do conteúdo mineralógico, estrutura e textura das rochas da Unidade Tambillito.

As rochas xistosas apresentam estrutura xistosa definida por bandas de espessura submilimétrica com textura lepidoblástica (ricas em muscovita, biotita e clorita) a nematolepidoblástica (formadas por biotita e sillimanita) alternadas por bandas descontínuas lenticulares de textura granoblástica (ricas em quartzo). Porfiroblastos de até $3 \mathrm{~mm}$ de estaurolita foram descritos em biotita-opacos-muscovita xisto com clorita e estaurolita, inequigranular fino (Prancha VII - Fotos 41 e 42).

Quartzitos impuros também foram descritos nessa unidade. Variam de granada-biotita-muscovita quartzito com clorita e pirita, de textura granoblástica equigranular fino a muscovita-biotita quartzito com plagioclásio, opacos e granada, de textura lepidogranoblástica equigranular fino.

Anfibolitos foliados de textura nematoblástica inequigranular médio, compostos por hornblenda, minerais do grupo do epidoto (zoisita e/ou epidoto/clinozoisita), quartzo, titanita ou rutilo e opacos foram descritos.

As rochas metapelíticas da Unidade Tambillito registram condições de metamorfismo de grau médio (pressão intermediária, fácies anfibolito) com xistos metapelíticos que apontam desde a zona da estaurolita (Puesto Tambillito - Prancha VII - Fotos 41 e 42) até a zona da sillimanita (primeira isógrada) (Rio Umango - Ponto UM651) como mostram as respectivas associações minerais: estaurolita-muscovitabiotita-quartzo, e sillimanita-muscovita-biotita-granada-plagioclásio. Em rochas metabásicas a associação mineral definida por hornblenda e minerais do grupo do epidoto caracteriza condições de metamorfismo de fácies anfibolito inferior, em concordância com as condições observadas no metapelitos. Essas associações minerais indicam um distinto gradiente metamórfico em relação à Unidade Tambillo.

\subsubsection{Granitóides}

Os granitóides mapeados podem ser divididos em dois grupos: granitóides sincolisionais (Granito El Peñon) e granitos tardi-póscolisionais (Granitos Los Guandacolinos e Cerro Veladero). 


\section{Prancha III}
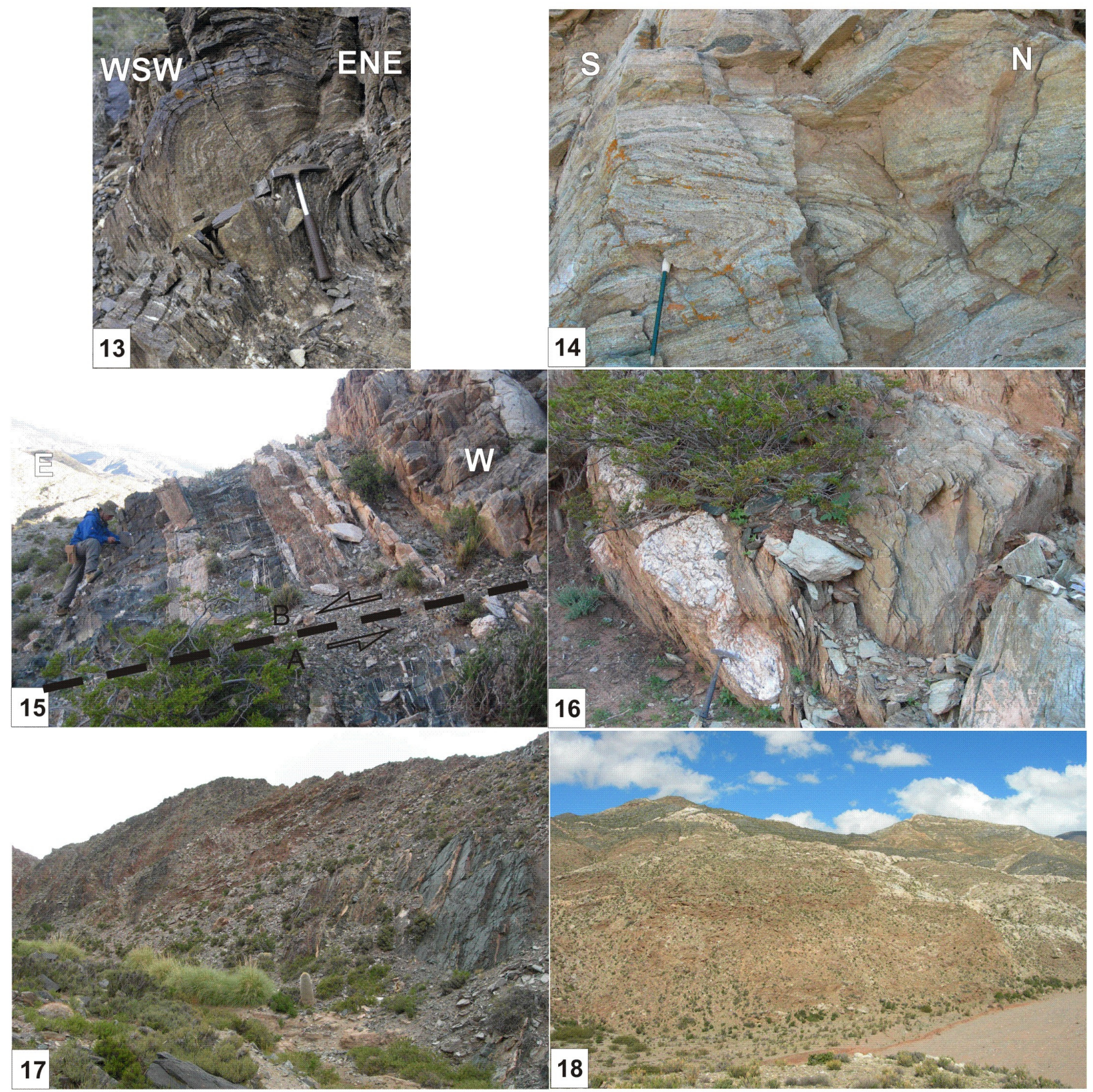

Foto 13: Xistos (meta-semipelitos) e veios estirados de quartzo dobrados em dobra recumbente pós-D2. Água Amarilla Ponto UM503.

Foto 14: Biotita quartzito feldspático com granada intercalado por bandas milimétricas de granada-clorita-muscovitabiotita-quartzo xisto. Ocorrem níveis de espessura centimétrica de anfibolitos dobrados intrafolialmente, em dobras sem raiz, em anzol (parte superior da foto) e dobras intrafoliais definidas pelo bandamento composicional. Puesto Umango, Ponto UM614.

Foto 15: Intercalações de espessuras centimétricas a decimétricas entre anfibolitos, mármores e mica-quartzo xistos no vale do Rio Umango. Nota-se a presença de falha normal rúptil (indicação de bloco baixo - B e bloco alto - A) com aparente deslocamento lateral esquerdo e rejeito aparente de aproximadamente 2,5 m. Ponto UM615.

Foto 16: Detalhe de veio pegmatítico foliado e concordante com a foliação do muscovita-quartzo xisto, à beira do Rio Umango (margem esquerda). Ponto UM-615.

Foto 17: Quebrada Tambillito e aspecto geral dos afloramentos da Unidade Tambillo. Intercalações de rochas calciossilicáticas, anfibolitos, mármores e quartzo xistos. Ponto UM655.

Foto 18: Vale do Rio Umango. No morro da margem direita do rio abservam-se xistos pelíticos a psamíticos (coloração marron) com veios pegmatíticos concordantes e discordantes (corpos esbranquiçados) à foliação principal S2 e intercalações de rochas metamáficas na parte superior do morro (colorações escuras). 


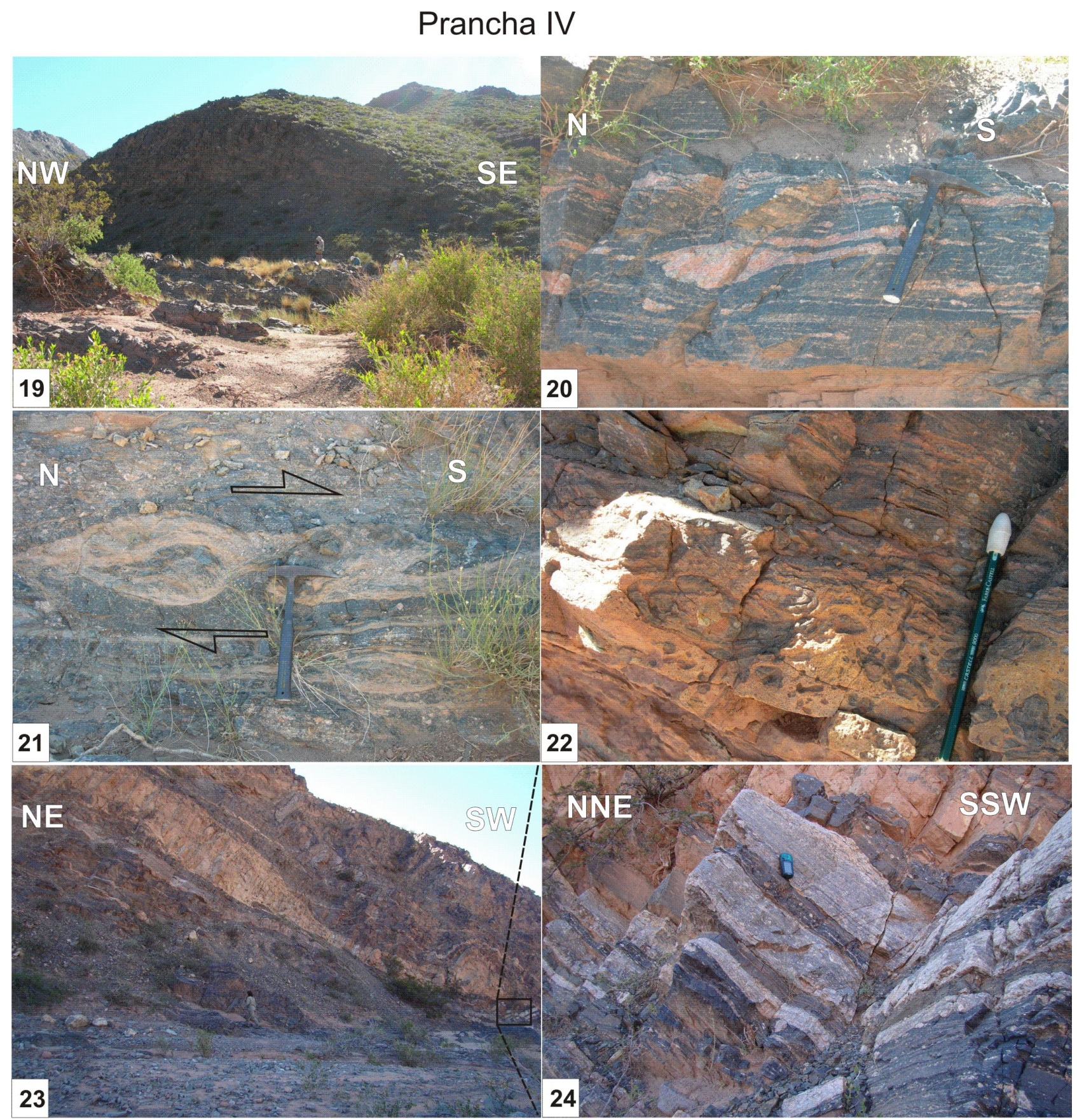

Foto 19: Aspecto geral dos afloramentos da ZCCP no Cerro Puntilla. Ponto UM602.

Foto 20: Milonitos máficos, ricos em biotita, aluminossilicato e granada com boudins/sigmóides pegmatíticos de composição granítica. Ponto UM602.

Foto 21: Boudins de rocha máfica em meio aos milonitos do Cerro Puntilla, com foliação interna e dobras assimétricas que sugerem movimentação dextral, de topo para S. Ponto UM602.

Foto 22: Mármores brechados com dobras intrafoliais definidas por fragmentos de rocha milonítica hospedeira. Ponto UM603.

Foto 23: Espessa camada boudinada de mármore intercalada em milonitos máficos e metabásicas milonitizadas. Ponto UM603.

Foto 24: Intercalações entre milonitos máficos metapelíticos (cinza escuro na base), milonitos graníticos de coloração cinza claro e mármore brechado (coloração alaranjada no topo). Ponto UM603, detalhe da foto anterior. 


\section{Prancha V}

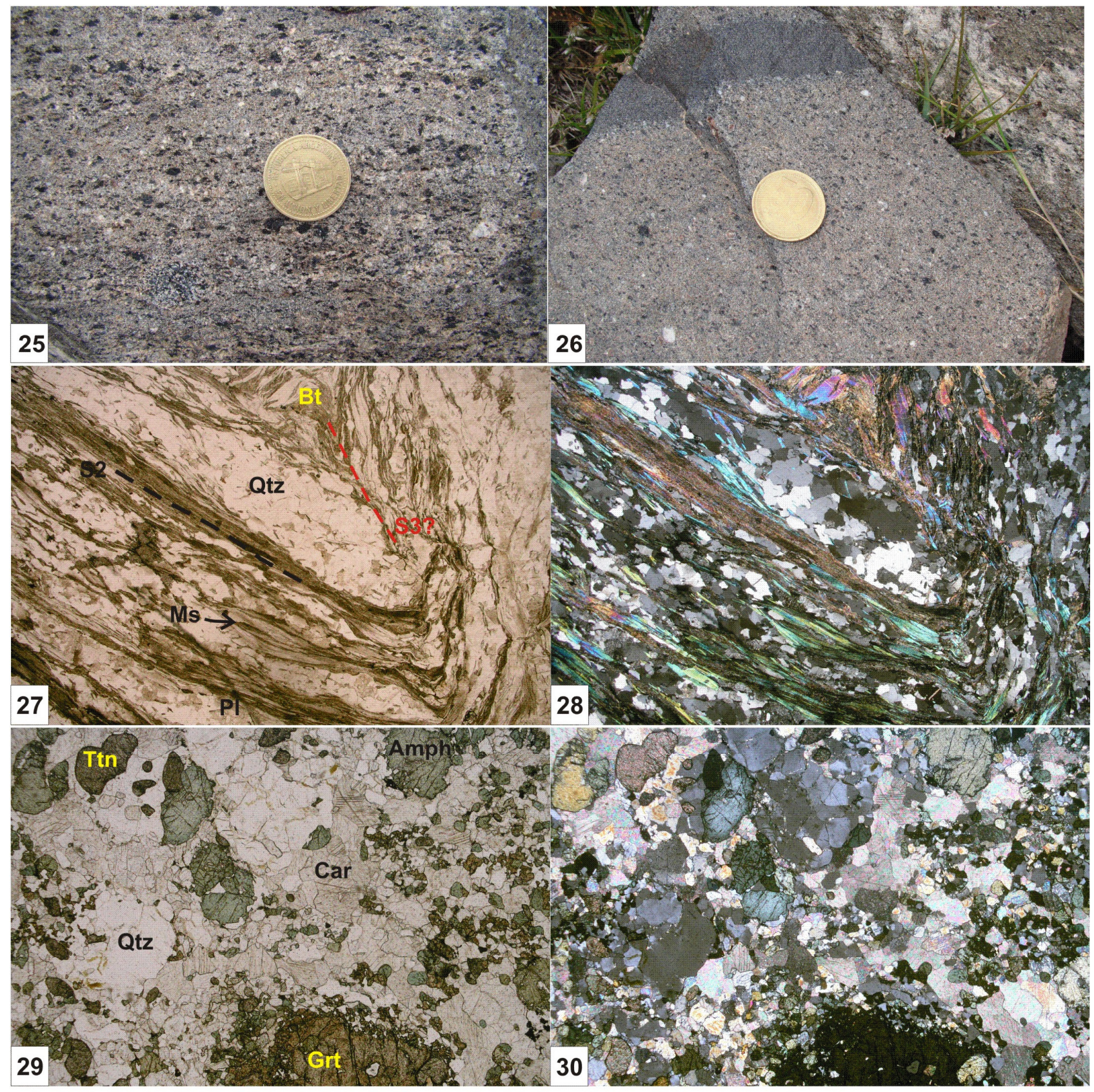

Foto 25: Estrutura geral foliada de metagabro com granada. Ponto UM822.

Foto 26: Metagabro com granada e enclave alongado, máfico microgranular. Ponto UM822.

Foto 27: Fotomicrografia de dobra assimétrica (pós-D2) da foliação principal S2 definida por bandas micáceas ricas em muscovita e biotita e bandas granoblásticas constituidas por quartzo e plagioclásio. Bt-Ms-PI-Qtz xisto com Grt. Unidade Tambillo, Amostra UM615B. Foto com nicóis paralelos e lado maior igual a 10,2mm.

Foto 28: Idem à foto $27 \mathrm{com}$ analisador inserido.

Foto 29: Fotomicrografia de trama granoblástica em rocha calciossilicática formada por granada, anfibólio, carbonato, titanita e quartzo. ZCCP, Amostra UM602E. Foto com nicóis paralelos e lado maior igual a 3,2mm.

Foto 30: Idem à foto 29 com analisador inserido. 


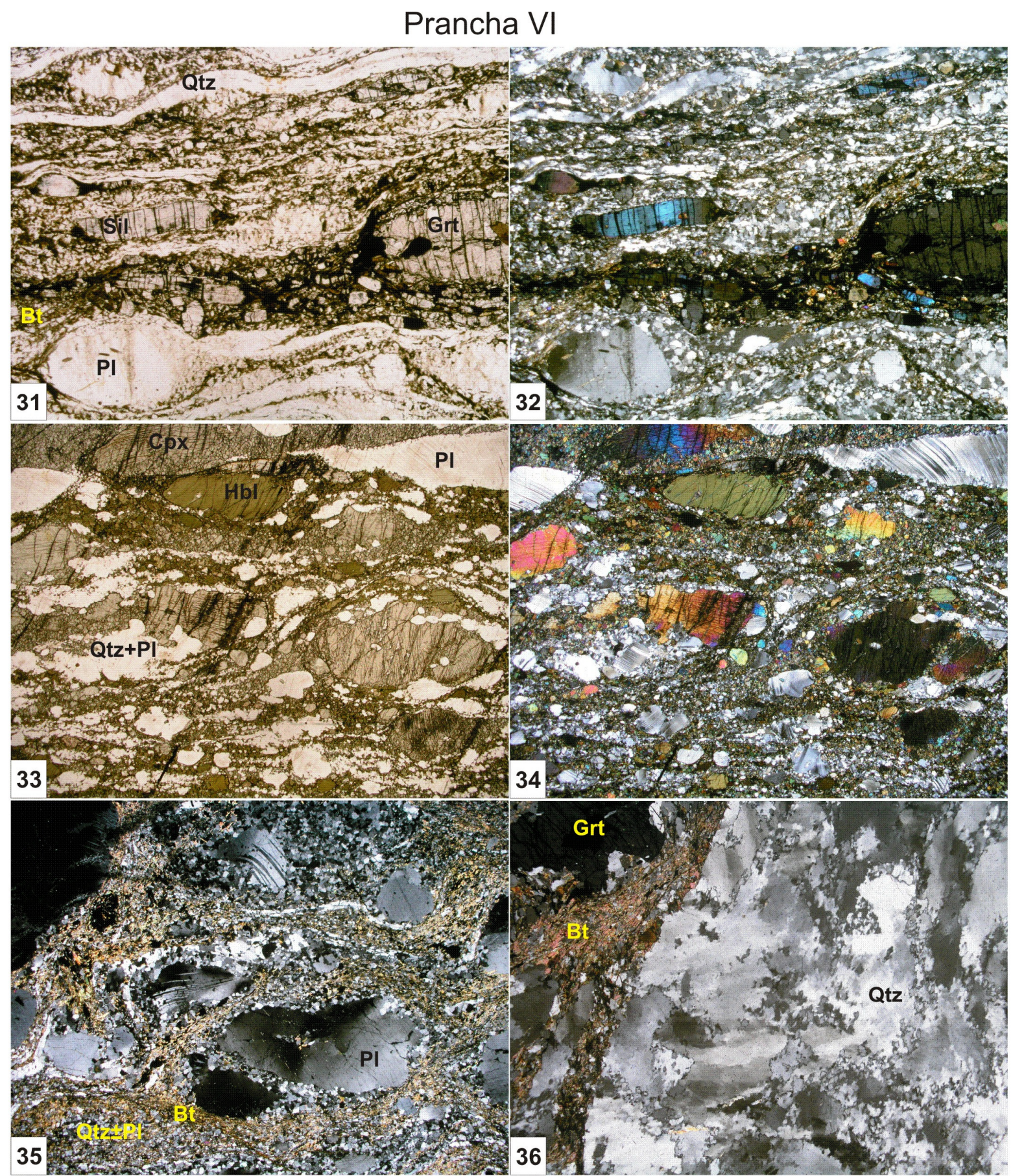

Foto 31: Fotomicrografia de milonito metassedimentar (pelito/"greywacke") com fitas de quartzo, porfiroclastos de plagioclásio, porfiroblastos de sillimanita deformados por dobras "kink", cristais de granada alongadas segundo à foliação milonítica S2 e cristais de granulação fina a muito fina de biotita (biotita cominuída). A foliação milonítica é definida pela alternância de bandas nematolepidoblásticas (formadas por sillimanita e biotita) e bandas granoblásticas, constituídas por quartzo e plagioclásio. ZCCP, Amostra UM542. Foto com nicóis paralelos e lado maior igual a $5,1 \mathrm{~mm}$.

Foto 32: Idem à foto $32 \mathrm{com}$ analisador inserido.

Foto 33: Fotomicrografia de rocha metamáfica milonitizada com porfiroclastos de clinopiroxênio, hornblenda e plagioclásio. Notar geminação induzida por deformação de porfiroclastos de plagioclásio. ZCCP, Amostra UM603B. Foto com nicóis paralelos e lado maior igual a $10,2 \mathrm{~mm}$.

Foto 34: Idem à foto $33 \mathrm{com}$ analisador inserido.

Foto 35: Fotomicrografia de estrutura geral de protomilonito rico em porfiroclastos de plagioclásio com geminação induzida por deformação e foliação milonítica definida por bandas lepidoblásicas ricas em biotita de granulação fina a muito fina e bandas granoblásticas ricas em quartzo. ZCCP, Amostra UM543A. Foto com nicóis paralelos e lado maior igual a $10,2 \mathrm{~mm}$.

Foto 36: Fotomicrografia de detalhe de texturas do tipo "bulging" e rotação de cristais de quartzo em banda granoblástica de milonito metassedimentar composto por biotita, granada, sillimanita, plagioclásio e quartzo. ZCCP, Amostra UM608A. Foto com nicóis paralelos e lado maior igual a $3,2 \mathrm{~mm}$. 


\section{Prancha VII}
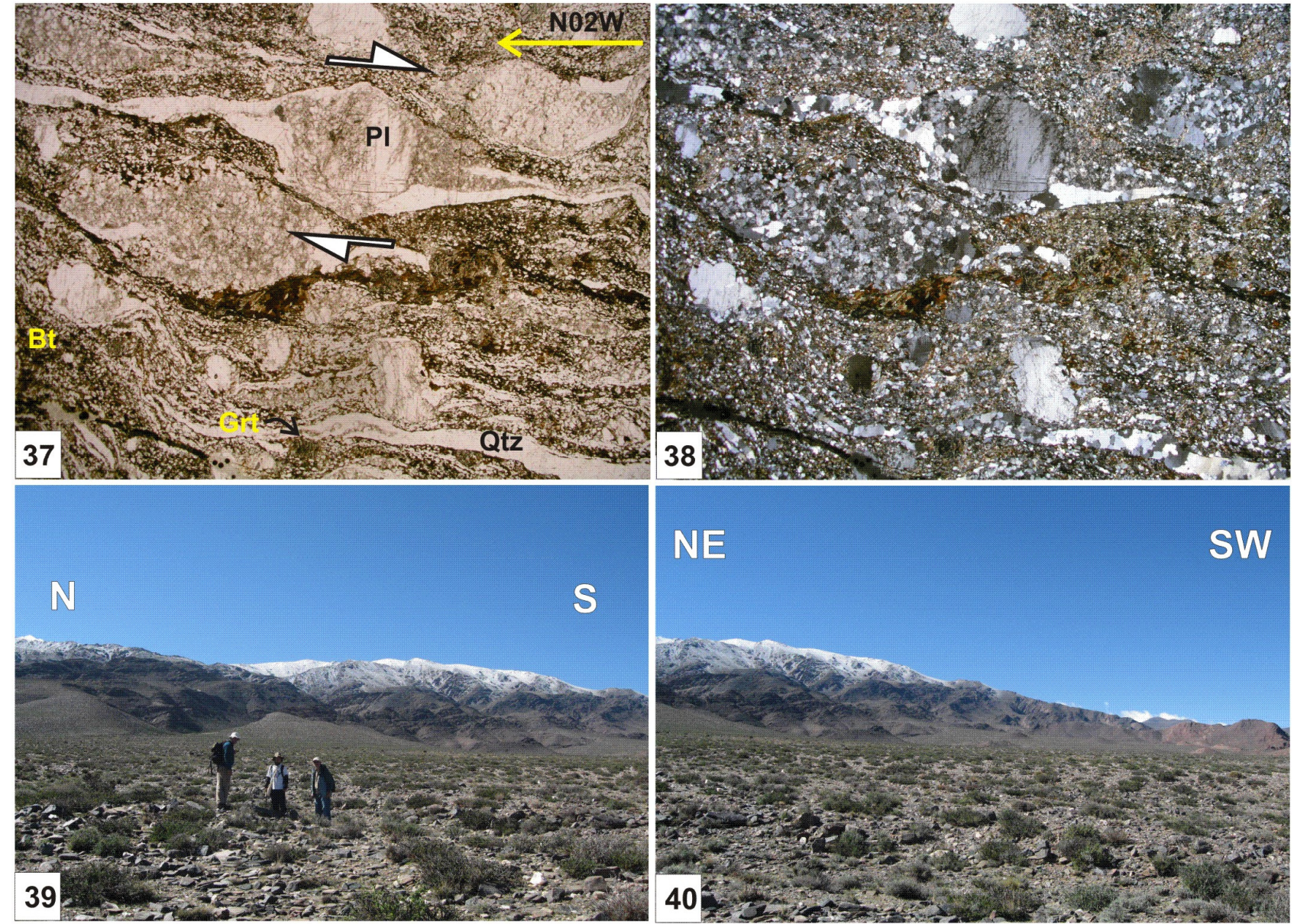

NE
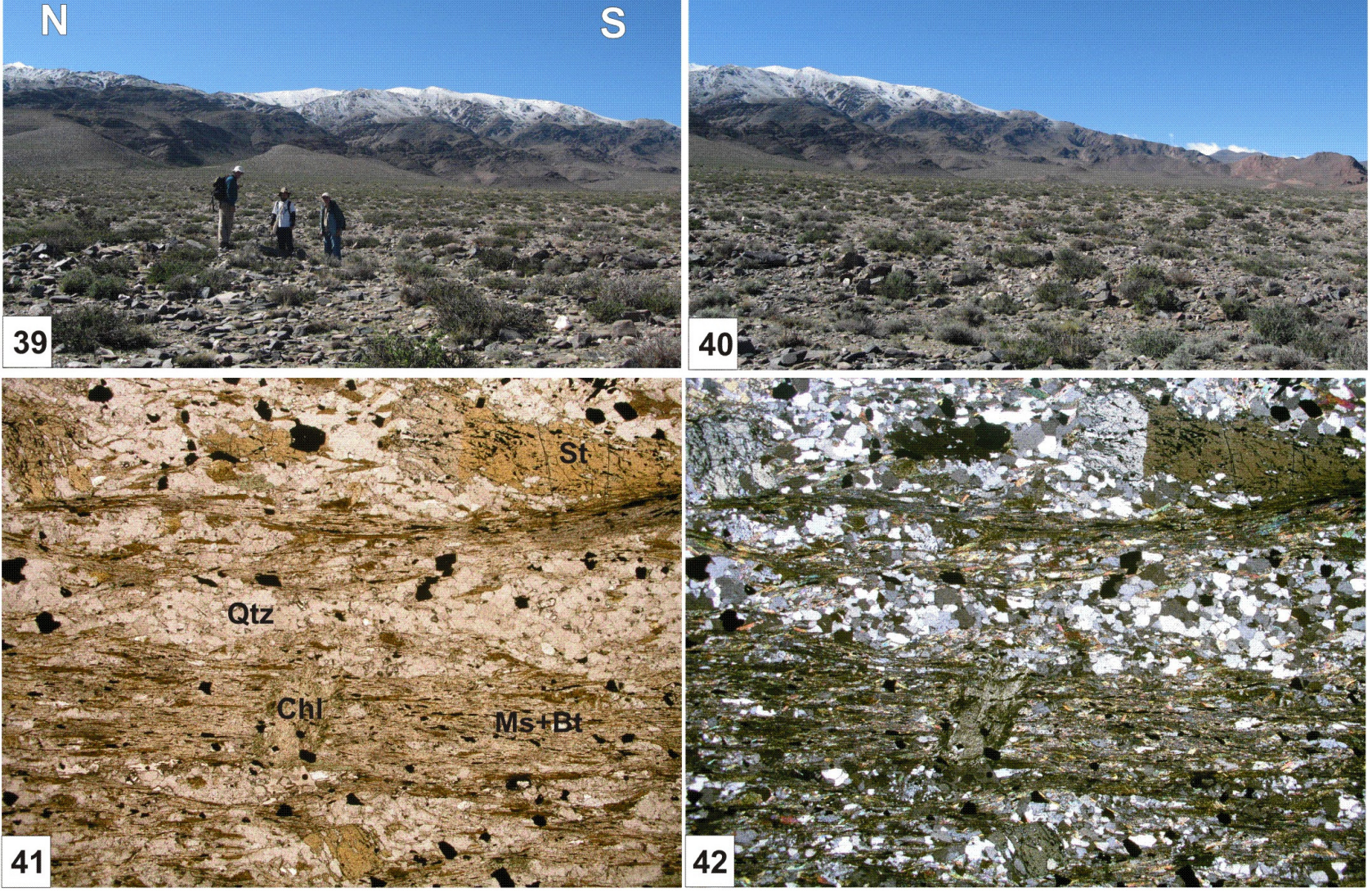

Foto 37: Fotomicrografia da estrutura geral de protomilonito formado por bandas lepidoblásticas ricas em biotita e bandas granoblásticas ricas em quartzo. Indicador cinemático do tipo delta em porfiroclasto de plagioclásio sugere movimentação dextral, evidenciando cinemática de topo para sul. Cerro Cacho, ZCCP, Amostra UM815A. Foto com nicóis paralelos e lado maior igual a 10,2 mm.

Foto 38: Idem à foto $37 \mathrm{com}$ analisador inserido.

Foto 39: Geólogos Pablo González, Vinícius Meira e Mário Campos com Quebrada Tambillito ao fundo.

Foto 40: Morro do Granito El Peñon (colorações avermelhadas no canto direito da foto).

Foto 41: Fotomicrografia de biotita-opacos-muscovita xisto com porfiroblastos de estaurolita e clorita. Porfiroblastos de estaurolita chegam a $3 \mathrm{~mm}$ de comprimento com bordas irregulares e foliação interna discordante da foliação externa. Unidade Tambillito, Amostra UM532H. Foto com nicóis paralelos e lado maior igual a 10,2 mm.

Foto 42: Idem à foto 41 com analisador inserido. 


\subsubsection{Granito El Peñon}

$\mathrm{Na}$ região sudeste da serra ocorre corpo tabular de granito milonítico denominado Granito El Peñon. Compõe um corpo alongado NNW-SSE de aproximadamente $8,5 \mathrm{Km}$ de extensão e espessura aparente de 400 metros, intercalado tectonicamente à unidade Tambillo (Prancha VII - Foto 40), nas imediações da zona de contato com a Unidade Tambillito. Predominam biotita granito milonítico vermelho, intensamente foliado e linear, com bandas de biotita granodiorito milonítico cinza, linear e porfiroclástico, por vezes com anfibólio. Aparece também como filões deformados intrusivos na seqüência Tambillo, principalmente na porção $E$ da unidade citada.

As rochas granodioríticas possuem opacos, hornblenda e biotita em textura milonítica inequigranular de granulação fina-média (Prancha VIII - Fotos 43 e 44). Apresentam bandas descontínuas sigmoidas definidas por agregados de hornblenda e opacos em matriz quartzo-feldspática granoblástica. Os grãos de feldspato (principalmente plagioclásio) apresentam granulação fina-média enquanto os grãos de quartzo possuem granulação fina.

\subsubsection{Granitos Los Guandacolinos e Cerro Veladero}

Os "stocks" graníticos Los Guandacolinos e Cerro Veladero foram mapeados na área de estudo, com detalhamento de campo do primeiro e interpretações dos contatos com base nas imagens de satélite.

No limite oeste da ZCCP aflora o Granito Los Guandacolinos (Prancha VIII Foto 45). O granito ocorre intrusivo na seqüência metassedimentar milonitizada da ZCCP e é caracterizado pela predominância de biotita sienogranito porfirítico hipidiomórfico, com índice de cor variando de hololeucocrático a leucocrático, róseo a cinza de granulação média-grossa, localmente com orientação mineral de fluxo ígneo (Prancha VIII - Foto 46). Enclaves máficos microgranulares ricos em biotita são freqüentes (Prancha VIII - Foto 47), ocorrendo também com freqüência xenólitos de rochas encaixantes. Localmente apresenta evidências de deformação no estado sólido, caracterizada pelo desenvolvimento de foliação protomilonítica.

No noroeste da Sierra de Umango (Seção Água La Falda - Ponto UM616) foram descritos injeções graníticas leucocráticas ricas em xenólitos metassedimentares e um granito milonítico intercalado às rochas milonitizadas da ZCCP (Prancha VIII - Foto 48; Prancha IX - Fotos 49 e 50 - ver na Seção Água La Falda lente estreita de granito em meio à ZCCP). Esses granitos foram interpretados 
em campo como correlatos ao Granito Los Guandacolinos. Nos subcapítulos Seções Geológicas e Microestrutural serão detalhadas a estrutura e a cinemática dessa rocha.

O Granito Cerro Veladero aflora a sul dos Ortognaisses Juchi e aparece como substrato para as rochas sedimentares da Bacia Paganzo. Trata-se de um anfibólio monzogranito subhipidiomórfico equigranular médio, rosado, rico em xenólitos e tetos pendentes de rocha sedimentar que sofreu metamorfismo de contato (Prancha IX Foto 51).

As visitas de campo realizadas não foram suficientes para esclarecer a relação entre o monzogranito, as rochas sedimentares do Paleozóico Superior (Bacia Paganzo) e as rochas metassedimentares e metaígneas da Sierra de Umango. Aparentemente, o "stock" Cerro Veladero não é intrusivo nas rochas sedimentares da Bacia Paganzo.

\subsubsection{Unidade de Rochas Metabásicas El Cordobés}

A Unidade El Cordobés corresponde a uma faixa de orientação N-S a NNESSW com predominância de metagabros de granulação grossa, anfibolitos e epidotohornblenda gnaisses com biotita e granada.

As regiões dos barreais Grande, Chico e Chiquitito possuem metagabros de granulação grossa como principal litotipo, com anfibolitos, anfibólio xistos, rochas calciossilicáticas e mica-quartzo xistos subordinados (Prancha IX - Fotos 52 e 53). Os afloramentos dessa unidade na Quebrada La Champa são caracterizados por uma seqüência de biotita-epidoto-anfibólio gnaisse bandado com bandamento retilíneo formado pela alternância de variadas proporções e granulometrias dos minerais. A orientação da foliação nessa unidade é concordante com a foliação S2 da rocha encaixante.

O predomínio de rochas metabásicas no Cerro El Cordobés foi relatado por Hausen (1921). A unidade encontra-se intercalada à Unidade Tambillo em estrutura sinformal. O refinamento estrutural e petrológico são imprescindíveis para melhor caracterizar essa unidade.

Lâminas delgadas das rochas gabróicas da região do Barreal Grande foram descritas. Correspondem a anfibolitos de estrutura foliada a maciça, inequigranular médio-grosso, compostos por hornblenda, plagioclásio, opacos e quartzo. Hornblenda apresenta-se subdioblástica a xenoblástica, plagioclásio e quartzo apresentam-se granoblásticos e opacos ocorrem intersticiais e em forma de grãos de granulação mais grossa (até $3 \mathrm{~mm}$ ) associados à coronas ricas em plagioclásio. As coronas de 
plagioclásio ocorrem frequentemente estiradas (ver detalhe em Prancha IX - Foto 53), definindo uma lineação, denominada neste trabalho de lineação de coronas.

\subsubsection{Seqüência Carbonática La Troya}

Uma seqüência de rochas sedimentares de baixo grau metamórfico foi reconhecida em contato tectônico com a ZCCP a leste e com a Formação Punilla a oeste. Corresponde a uma fatia tectônica caracterizada pelas intercalações de metacalcáreos silicificados de coloração alaranjada, ardósias e filitos acinzentados a prateados (Prancha IX - Foto 54 e Prancha X - 55). É possível observar, nos planos de foliação filítica, porfiroblastos em bastonetes com forma de leques, levemente alterados para mica branca de granulação fina.

Essa unidade será associada, tentativamente nesse trabalho, aos Carbonatos Las Damas do Complexo Metamórfico Rio Bonete (Acenõlanza et al., 1971 e Martina \& Astini, 2009).

\subsubsection{Coberturas Sedimentares}

Bacias sedimentares invertidas do Paleozóico Superior e do Mesozóico, e coberturas sedimentares cenozóicas completam o quadro litológico da serra.

A Bacia Paganzo representa as rochas sedimentares do Carbonífero Superior ao Permiano, e são interpretadas como pertencentes a bacias extensionais de retroarco (Limarino et al., 2002). As bacias de rifte do Triássico e do Cretáceo também são vinculadas a eventos extensionais na borda de Gondwana, freqüentemente associadas à história de abertura do Oceano Atlântico (Ramos et al., 1988a).

As rochas cenozóicas depositadas em bacias de retroarco apresentam-se deformadas, principalmente as formações Puesto La Flecha, Vinchina, Zapallar, El Corral e Toro Negro, que datam do Oligoceno ao Plioceno (Caminos \& Fauqué, 1999).

\subsection{Análise Estrutural}

A análise estrutural da área estudada foi feita com base nas observações de campo e nas medidas estruturais coletadas. As medidas estruturais estão expressas em notação Clar (rumo do mergulho ou do caimento). As etapas de campo foram concentradas em algumas regiões da serra e em perfis ao longo de drenagens ( "quebradas"). 


\section{Prancha VIII}
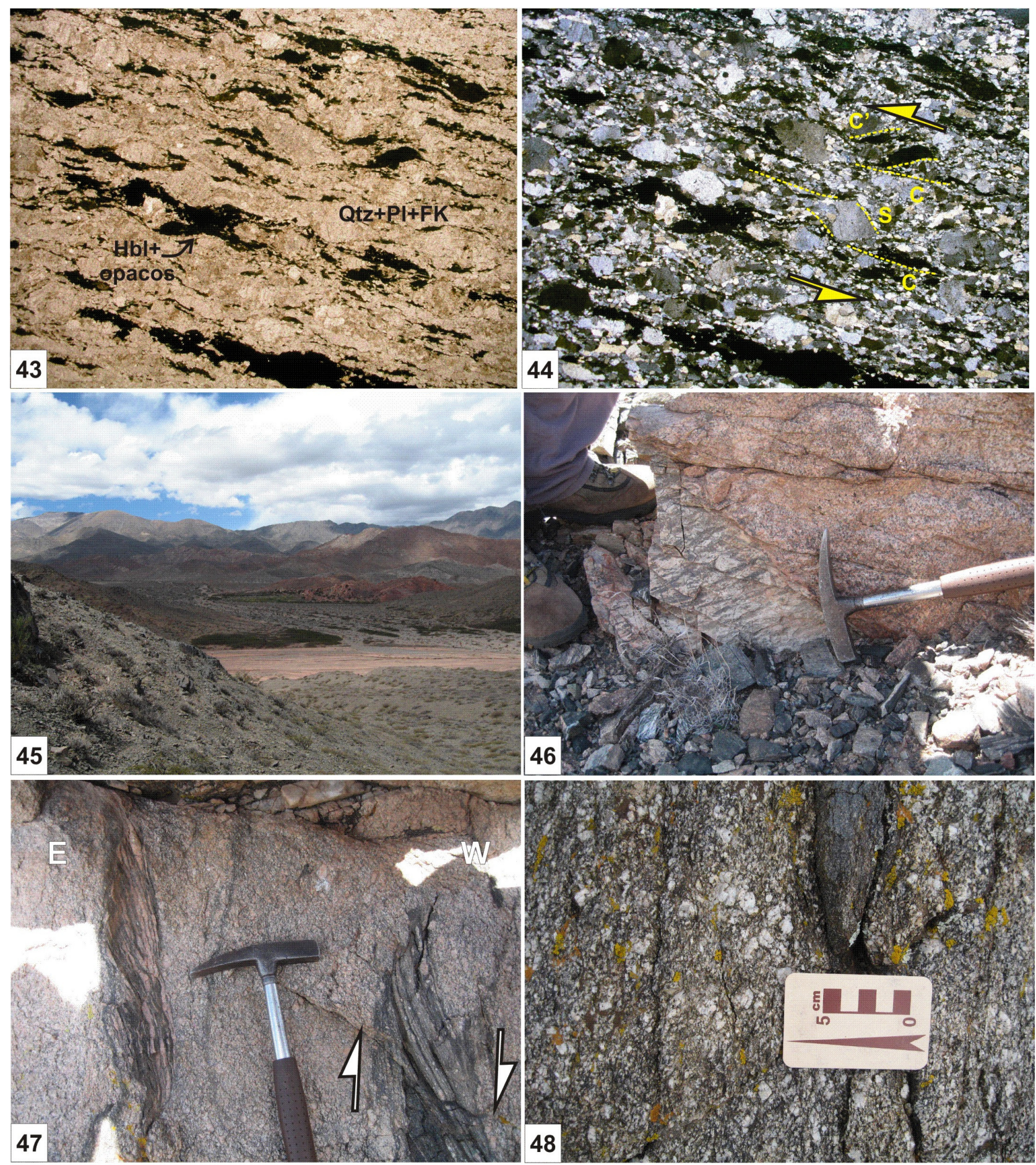

Foto 43: Fotomicrografia de opacos-hornblenda gnaisse com biotita, porfiroclástico inequigranular fino-médio. Notar indicadores cinemáticos tipo sigma e bandas extensionais de cisalhamento (C') indicando movimentação sinistral. Granito EI Peñon, Ponto UM512. Foto com nicóis paralelos e lado maior igual a 10,2 mm.

Foto 44: Idem à foto 43 com analisador inserido.

Foto 45: Visada para leste do Ponto UM605 (Sierra de Las Minitas). Observamos em primeiro plano o vale do Rio de La Troya, em segundo plano, de coloração alaranjada, o Granito Los Guandacolinos e em terceiro plano as rochas da ZCCP na continuação da serra Cerro Cacho-Cerro Puntilla.

Foto 46: Contato intrusivo entre Granito Los Guandacolinos e rochas da ZCCP. Ponto UM609.

Foto 47: Granito Los Guandacolinos foliado de aspecto protommilonítico, com xenólitos/enclaves sigmoidais indicando movimentação dextral. Ponto UM610.

Foto 48: Granito protomilonítico leucocrático inequigranular médio.Granito Los Guandacolinos, Ponto UM616. 


\section{Prancha IX}
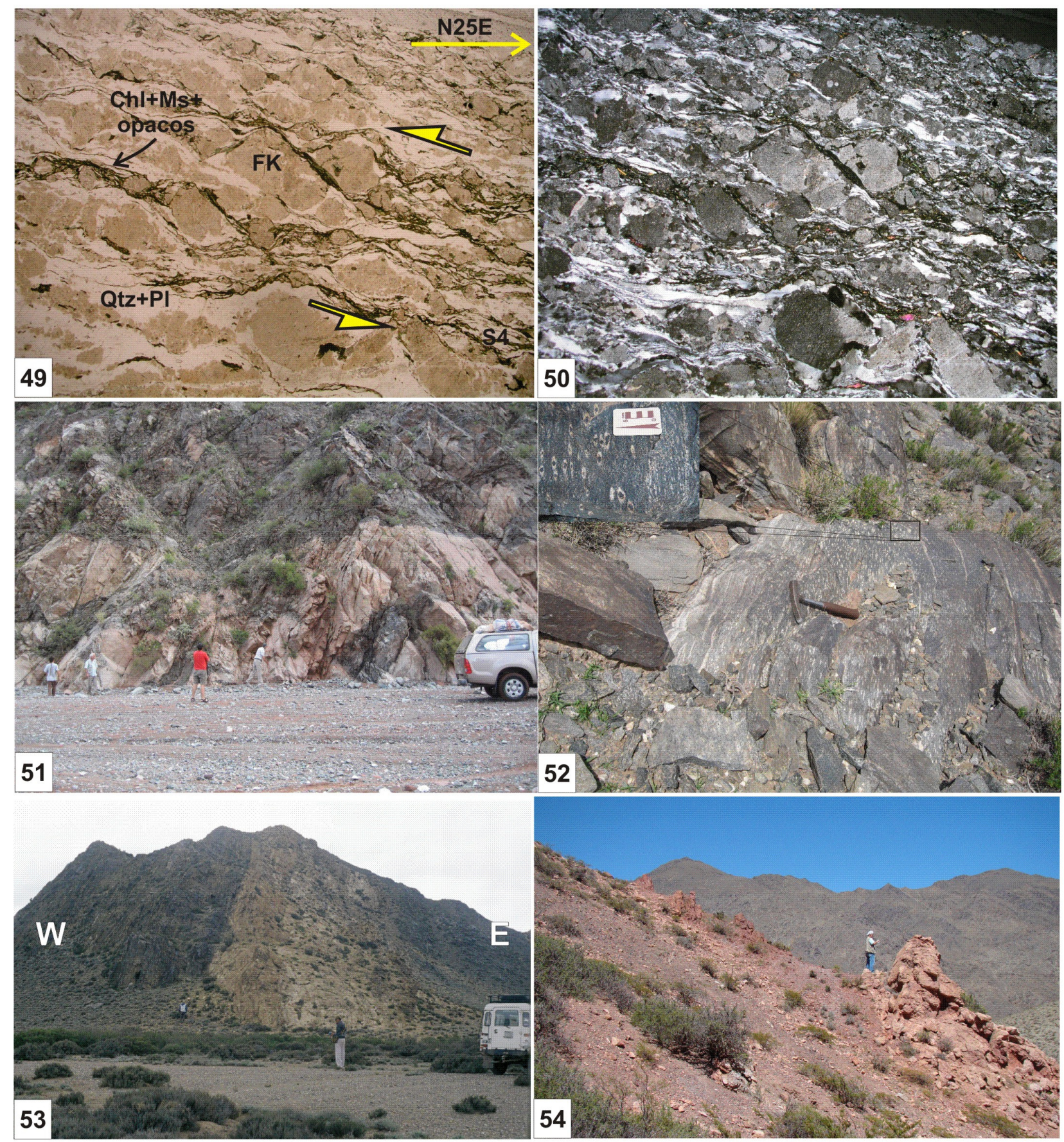

Foto 49: Fotomicrografia de muscovita-clorita-plagioclásio-feldspato potássico protomilonito rico em porfiroclastos de feldspato potássico e leitos descontínuos lepidoblásticos formados por clorita, muscovita e opacos. Indicadores cinemáticos do tipo sigma sugerem movimentação sinistral, com transporte no sentido contrário do caimento da lineação de estiramento (N25E/10). Granito Los Guandacolinos, Amostra UM616F. Foto com nicóis paralelos e lado maior igual a 10,2mm.

Foto 50: Idem à foto $49 \mathrm{com}$ analisador inserido.

Foto 51: Aspecto geral dos afloramentos do Granito Cerro Veladero. Monzogranito rosado com xenólitos e tetos pendentes de rocha de coloração cinza escura. Ponto UM601.

Foto 52: Aspecto geral do metagabro coronítico inequigranular grosso foliado da Unidade El Cordobés. Ponto UM622.

Foto 53: Espessa camada de mármore que limita o lado oeste da Unidade El Cordobés (contato com a Unidade Tambillo) na região do Barreal Grande. Notar que a foliação das rochas máficas à leste da camada de mármore é paralela à estruturação da Unidade Tambillo. Ponto UM540.

Foto 54: Camadas verticalizadas de poucos metros de espessura de metacarbonatos silicificados de coloração alaranjada. Seqüência Carbonática La Troya, Ponto UM814. 


\section{Prancha X}
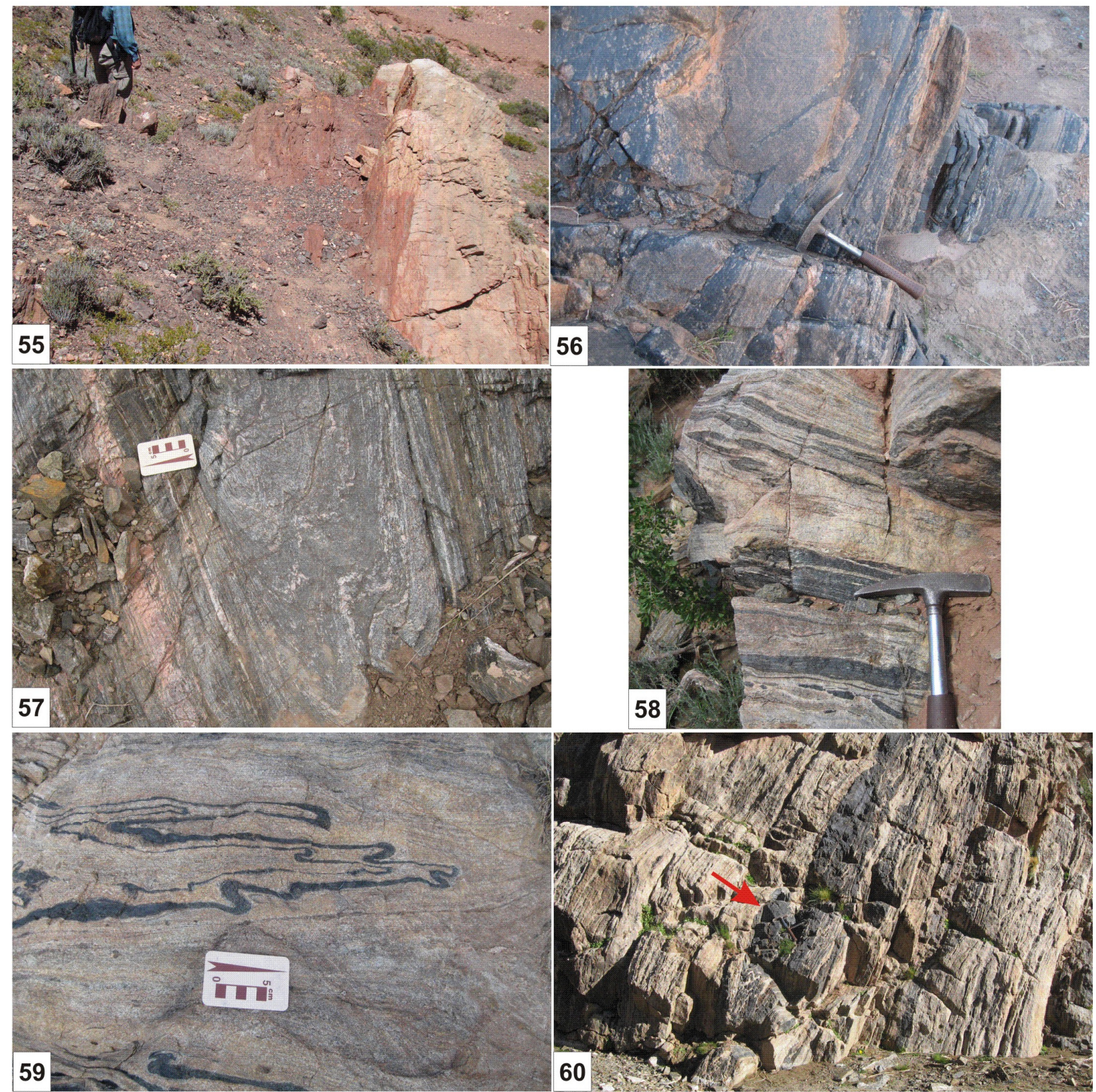

Foto 55: Intercalações entre filitos e ardósias (rochas placosas de coloração cinza escura), e metacarbonatos silicificados (coloração alaranjada). Sequencia Carbonática La Troya, Ponto UM814.

Foto 56: Rocha bandada caracterizada pela intercalação de bandas metapelíticas milonitizadas com porfiroblastos de granada (coloração cinza escura), bandas graníticas (coloração cinza claro) e bandas pegmatóides (coloração rosada). A banda granítica acima do martelo apresenta-se boudinada e dobrada, definindo dobras intrafoliais D2. ZCCP, Ponto UM608.

Foto 57: Dobra isoclinal e intrafolial D2 em biotita gnaisse. Ortognaisses Juchi, Ponto UM617.

Foto 58: Intercalações de espessura centimétricas entre mármore e rochas metamáficas. Camadas de rochas metamáficas definem dobras intrafoliais D2 e apresentam-se boudinadas. Unidade Tambillo, Ponto UM619.

Foto 59: Dobras intrafoliais D2 definida por banda de rocha metamáfica. Unidade Tambillo, Ponto UM619.

Foto 60: Intercalações de bandas de até $20 \mathrm{~cm}$ de espessura de anfibolito em meio à mármore bege bandado. Camada mais espessa apresenta dobras intrafoliais D2 (parte inferior da camada) e encontra-se boudinada. Seta vermelha indica localização de martelo como escala. Unidade Tambillo, Puesto Umango, Ponto UM704. 


\subsubsection{Principais Estruturas}

Trabalhos anteriores (Fernandes et al., 2001, Fernandes et al., 2002 e Porcher et al., 2004) descrevem dois conjuntos de dobras isoclinais a apertadas, denominados de F1 e F2, nas rochas das serras de Maz, Espinal, Las Ramaditas e Umango. Os autores associam essas dobras e o bandamento composicional a um episódio deformacional principal registrado nessas rochas. Para os autores acima citados, o bandamento composicional teria orientação original subhorizontal, e foi deformada por duas fases de dobramentos posteriores (F3 e F4). A fase F3 foi caracterizada por dobras concêntricas, abertas a apertadas, normais a inclinadas, com planos axiais orientados NW-SE a N-S, enquanto a fase F4 representaria dobras normais de eixos $\mathrm{NE}$, desenvolvidos principalmente nos flancos das dobras F3 (Porcher et al., 2004).

Neste trabalho consideramos a foliação principal, denominada de bandamento composicional pelos autores supracitados, como uma foliação metamórfica S2 definida principalmente pela orientação de minerais micáceos e anfibólio, associados aos planos axiais de dobras intrafoliais. A foliação S2 representa uma foliação de transposição e é observada geralmente paralela ao bandamento composicional. As dobras isoclinais recumbentes D2 (F1 e F2 de Fernandez et al., 2002) podem ser observadas nas escalas mesoscópica (afloramentos - Prancha I - Foto 1; Prancha III Foto 14; Prancha IV - Foto 22; Prancha X - Fotos 56, 57, 58, 59 e 60; Prancha XI Fotos 61, 62 e 64) e macroscópica (imagens de satélite e seções geológicas - ver figuras 8, 9, 10 e 11). Dobras em bainha (D2) também foram observadas. Estruturas lineares de estiramento e lineações minerais estão relacionadas à foliação principal (S2). Lineações definidas pelo estiramento de coronas de plagioclásio, que envolvem minerais opacos, ocorrem nos metagabros da Unidade El Cordobés e foram designadas como lineação de coronas (Prancha IX - Foto 52). Na ZCCP, a foliação principal corresponde a uma foliação milonítica definida por leitos biotíticos ricos em porfiroblastos sincinemáticos de granada e porfiroclastos feldspáticos (Prancha IV Fotos 19, 20, 21, 22, 23 e 24; Prancha XI - Foto 63), interpretada como correlata à fase deformacional D2.

A foliação reliquiar S1 é reconhecida principalmente em zonas de charneiras de dobras intrafoliais isoclinais (D2) e paralelas a camadas anfibolíticas de espessura centimétrica intercaladas em mármores (Prancha XI - Fotos 61 e 64), dobras intrafoliais assimétricas definidas por vênulas de quartzo e, por vezes, pelo próprio bandamento composicional (Prancha III - Foto 14). 


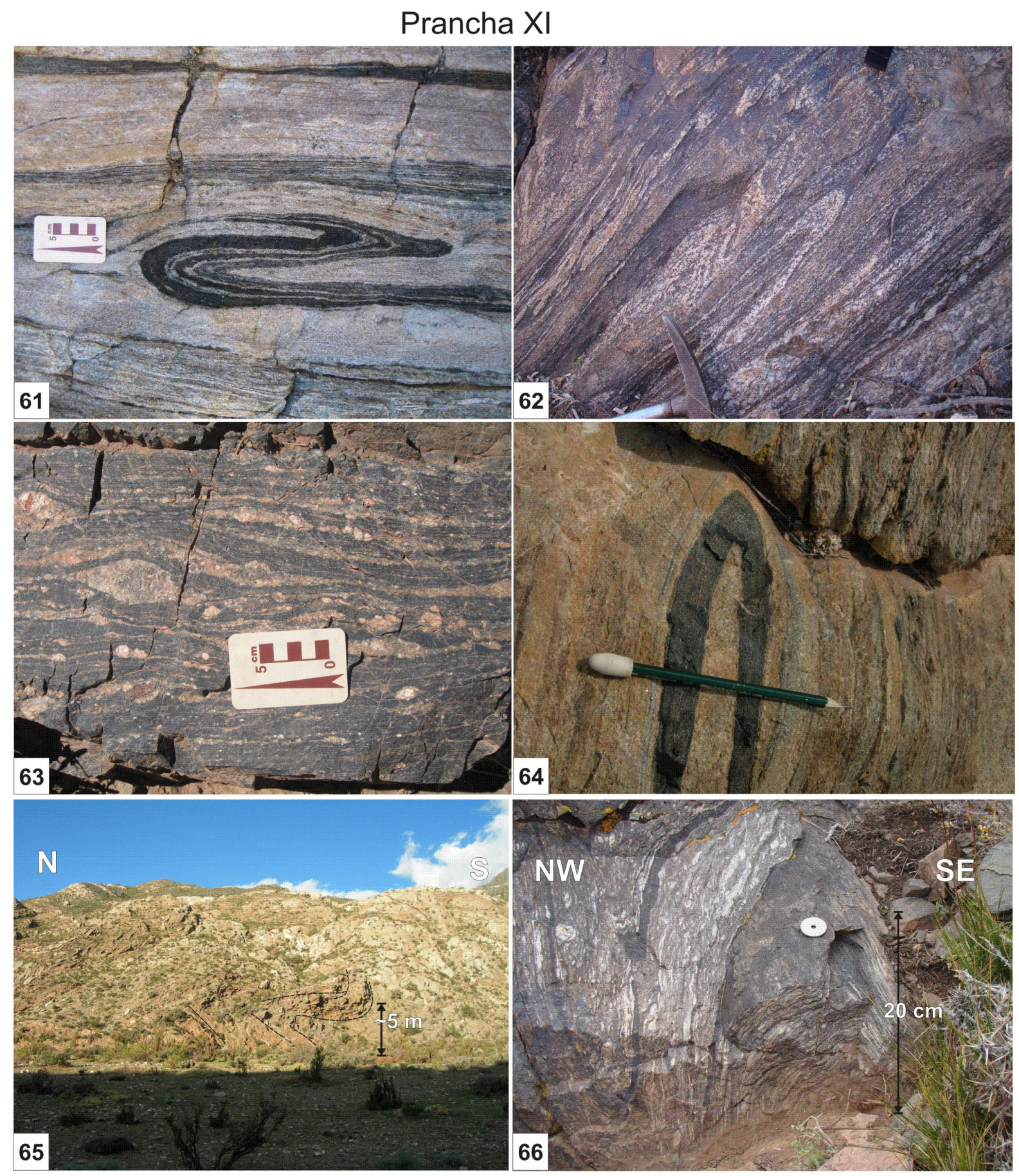

Foto 61: Dobra intrafolial sem raiz D2, definida por restos de foliação S1 em leito bandado constituído pela alternância de bandas de espessuras subcentimétricas a centimétricas de anfibolito e mármore. Unidade Tambillo, Puesto Umango, Ponto UM704.

Foto 62: Dobras intrafoliais em biotita gnaisse definidas por bandas félsicas quartzo-feldspáticas e bandas máficas ricas em biotita. Ortognaisses Juchi.

Foto 63: Aspecto geral de foliação milonítica a protomilonítica em metagrauvaca com bandas félsicas estiradas ricas em porfiroclastos feldspáticos e porfiroblastos estirados de granada. ZCCP, Ponto UM602.

Foto 64: Dobra intrafolial isoclinal definida por camada de espessura de aproximadamente $2 \mathrm{~cm}$ de anfibolito foliado. É possível observar que foliação interna corresponde à foliação S1, transposta pelo dobramento D2 e pela foliação S2. Unidade Tambillo, Ponto UM620.

Foto 65: Dobras assimétricas pós-D2 (D3?) em extenso afloramento na margem leste do Rio Umango. Fotografia tirada do Ponto UM615, visada para leste (leito seco e margem leste do Rio Umango), onde afloram predominantemente xistos quartzosos e micáceos, anfibolitos subordinados intercalados e veios concordantes e discordantes de pegmatóides. Linha tracejada marca o traço da foliação S2 dobrada. Unidade Tambillo.

Foto 66: Milonitos félsicos de composição granítica com bandas subcentimétricas de milonitos máficos (metabásicas). Dobras pós-D2, fechada, inclinada com sinforma apertada, deformam a foliação milonítica S2. ZCCP, Ponto UM823a. 
Pelo menos três fases de dobramentos (D3, D4 e D5) deformaram a orientação original da foliação principal (S2).

Dobras assimétricas fechadas a apertadas, inclinadas a recumbentes (Prancha I - Foto 3; Prancha III - Foto 13; Prancha XI - Fotos 65 e 66; Prancha XII - Fotos, 67, 68, 69 e 70) foram observadas, localmente com figuras de interferência de dobras normais abertas posteriores (possivelmente D4). e tentativamente associadas à fase de dobramentos D3. Geralmente, possuem flancos rompidos em falhas inversas e cavalgamentos, com presença de xistosidade plano axial ou xistosidade oblíqua, definidas pela recristalização de biotita e/ou muscovita, em rochas metapelíticas. Contudo, nem todas as dobras fechadas associadas a falhas inversas correspondem a dobras D3, podendo estar relacionadas à deformação flexural de flancos de dobras posteriores (D4).

As estruturas deformacionais denominadas D4 (fase F3 de Fernandes et al., 2001) são caracterizadas principalmente por dobras que variam de abertas a fechadas, normais a inclinadas e representam a principal estrutura da serra, a qual controla a orientação da foliação metamórfica principal S2. Orientam-se principalmente com eixo N-S, ocorrendo também eixos de orientação NE-SW. O comprimento de onda dessas estruturas varia entre 5 a $10 \mathrm{~km}$ e a amplitude mede cerca de $1 \mathrm{~km}$ (Prancha XII - Foto 71), correspondendo a dobras flexurais com concentração de deformação nos flancos. Interpreta-se que as dobras que afetaram a Formação Punilla, visíveis em escala de mapa, sejam correlatas a esse tipo de estruturas. Zonas de cisalhamento protomiloníticas foram identificadas no Granito Los Guandacolinos, marcadas pela presença de foliação protomilonítica, em estado sólido, e também foram associadas à fase deformacional D4.

Dobras abertas com eixos medidos de orientação E-W e alto ângulo de caimento axial foram relacionadas à fase de dobramentos D5 (Prancha XII - Foto 72). As formas sigmoidais das unidades mapeadas, principalmente da ZCCP, foram associadas a essa fase de dobramento. A análise de esteoreogramas com dispersões de lineações e pólos de planos de foliação (ver discussão em Seções Geológicas) reforça a possibilidade de existência dessas estruturas.

O soerguimento das rochas metamórficas e ígneas das Sierras Pampeanas Ocidentais foi causado pela tectônica recente andina (ver Figura 5). As dobras e falhas de cavalgamento associada às rochas sedimentares terciárias completam a evolução estrutural da região. As estruturas e falhas anteriores possivelmente foram reativadas nessa última fase de deformação. 


\section{Prancha XII}

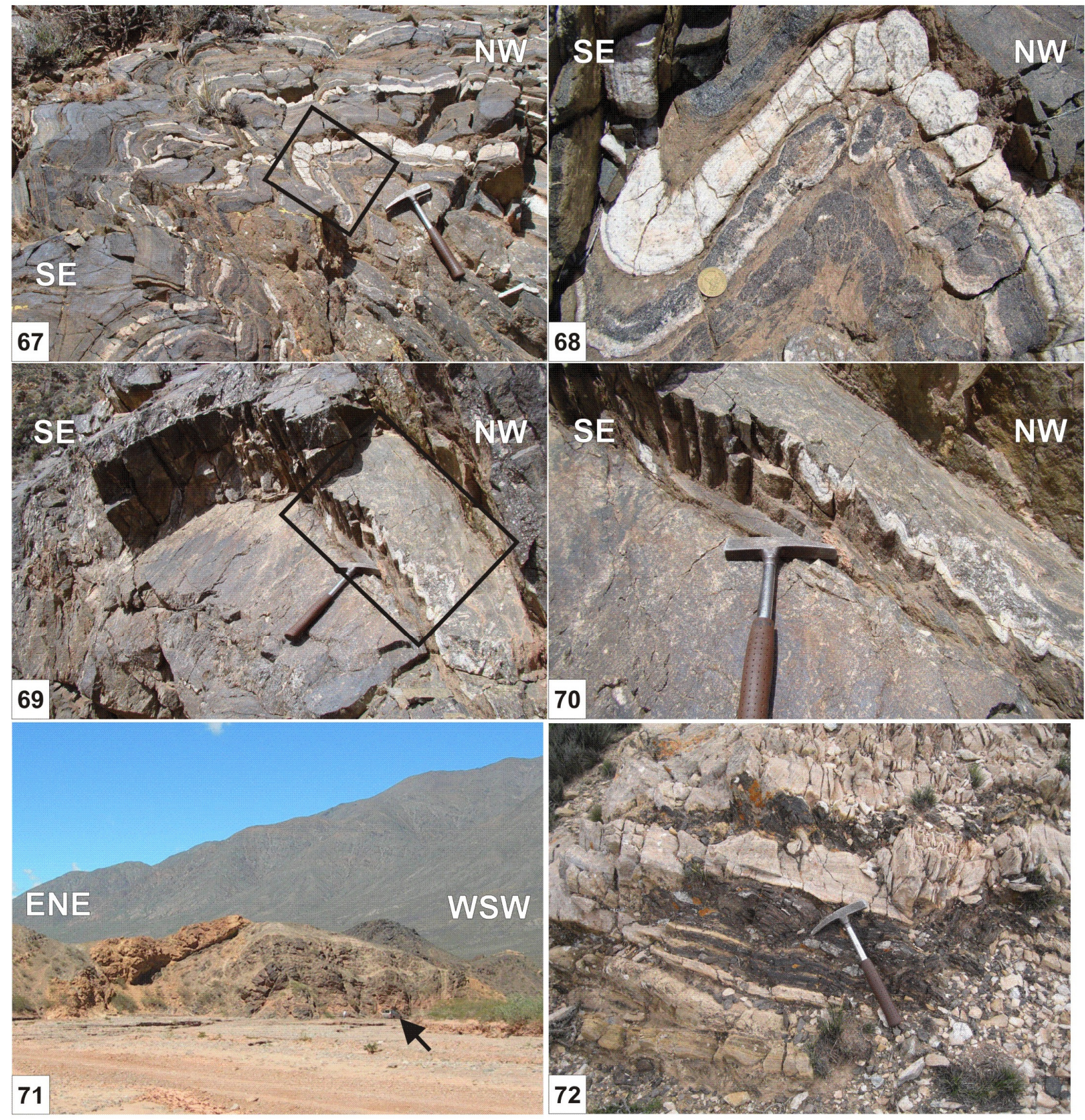

Foto 67: Dobras fechadas assimétricas e inclinada pós-D2 que deforma foliação milonítica S2. O afloramento é caracterizado por intercalações entre bandas de coloração cinza escura (predominante) de granada-biotita gnaisse milonítico com sillimanita, bandas brancas de milonitos félsicos de composição tonalítica, ricas em porfiroclastos de feldspato branco (plagioclásio), e boudins e bandas boudinadas de rochas metabásicas. Retângulo representa a localização da foto 46. ZCCP, Ponto UM819.

Foto 68: Detalhe de dobra da foto anterior. Dobra pós-D2 classificada como do tipo 1C, com leve espessamento de charneira. Notar a presença de foliação incipiente (S3?) formada na antiforma de banda máfica de granulação fina.

Foto 69: Dobra assimétrica e inclinada pós-D2 com dobras parasitas em forma de "z" e eixos definidos por mullions. Retângulo representa a localização da foto 48. ZCCP, Ponto UM819.

Foto 70: Detalhe de mullions formados por eixos B de dobras parasitas pós-D2. ZCCP, Ponto UM819.

Foto 71: Dobras abertas pós-D2 (possivelmente D4) observadas em intercalações entre camadas de mármore brechado (coloração alaranjada, na parte superior do afloramento) e milonitos metapelíticos com granada e aluminossilicato (coloração cinza escura). Em primeiro plano aparece o leito do Rio de La Troya e ao fundo a Sierra de La Punilla. Seta mostra caminhonete como escala. Cerro Puntilla, ZCCP, Ponto UM603.

Foto 72: Dobras suaves com charneira em cúspide e eixos B de alto ângulo de caimento associadas à fase deformacional D5. Intercalações entre camadas de mármore e anfibolitos. Unidade Tambillo, Ponto UM702. 


\subsubsection{Seções Geológicas}

As seções geológicas detalhadas facilitam a discussão sobre a hierarquização dos eventos deformacionais e o detalhamento das estruturas apresentadas acima.

Os mapas geológicos e seções em escala de detalhe estão apresentados nas figuras 9, 10 e 11. Os estereogramas apresentados correspondem à projeção de linhas e pólo de planos no hemisfério inferior da rede estereográfica de SchimdtLambert.

\subsubsection{Seção Água La Falda}

A seção geológica da Água La Falda (Figura 9a) localiza-se no noroeste da área de estudo e inicia-se, a oeste, nas rochas sedimentares devonianas da Formação Punilla (Sierra de Las Minitas), atravessa a Zona de Cisalhamento Cerro CachoPuntilla (ZCCP) e parte da Unidade Tambillo, incluindo uma sinforme do embasamento (Ortognaisses Juchi) sobreposta à Unidade Tambillo.

O contato entre as rochas sedimentares da Formação Punilla e as rochas miloníticas da ZCCP corresponde a uma falha (ou zona de cisalhamento) transcorrente sinistral com incipiente componente inverso para SE. As foliações medidas nos milonitos metassedimentares e no granito milonítico (Ponto UM616) apresentam direção NE-SW e alto ângulo de mergulho, e as lineações de estiramento possuem caimento subhorizontal na direção NE-SW (Figura 9a - Estereograma A). A seta com sentido de movimento foi obtida com base em indicador cinemático microestrutural (ver discussão em Microtectônica), corroborado pelos indicadores observados no campo. A deformação por cisalhamento simples imposta aos granitos, os quais foram interpretados como correlatos ao Granito Los Guandacolinos, sugere a correlação deste contato (zona de cisalhamento) com a fase deformacional D4, possivelmente reativado no terciário.

A dispersão dos pólos da foliação principal S2 no estereograma B (Figura 9a) sugere dobra com eixo E-W com alto ângulo de caimento (283/60). Dobras de eixo EW foram identificadas em outros estereogramas, como será discutido a seguir, assim como no desenho do contato oriental da ZCCP. Estas estruturas foram interpretadas como correspondentes a dobras D5. Dobras de eixo E-W também poderiam explicar a dispersão de lineações de estiramento e mineral pretéritas nos quadrantes NE e SW (Figuras 9a - Estereograma B).

Ao longo de toda seção observam-se dobras normais que deformaram a foliação principal S2, exemplificada na estrutura sinfomal onde repousam as rochas 
gnáissicas e metabásicas do embasamento (Ortognaisses Juchi). Destaca-se, na parte interna da sinforme na seção geológica, asterisco com a localização dos boudins de granada-clinopiroxênio anfibolito, descritos anteriormente (Prancha I - Foto 6; Prancha II - Fotos 9 e 10). A estrutura sinformal representa dobras D4 e é caracterizada pela dispersão da foliação $S 2$ nos flancos da dobra e eixo B medido 200/23 (Figura 9a - Estereograma C). Os dados analisados demonstram que a dobra é acilíndrica com duplo caimento axial, charneiras agudas e flancos de alto mergulho, meio comprimento de onda com cerca de $1 \mathrm{~km}$ e amplitude estimada de aproximadamente $1 \mathrm{~km}$. A sinforme descrita acima define a "Klippe Água La Falda". A klippe possui lineações minerais e de estiramento, relacionadas a um transporte geral para S-SW, concentradas nos quadrantes NE e SW, enquanto as foliações S2 apresentam ainda dispersões sugestivas de deformações de dobras E-W (D5?) (Figura 9a - Estereograma C).

\subsubsection{Seção Cerro Cacho - Rio Umango}

A seção geológica Cerro Cacho - Rio Umango atravessa grande parte da estrutura no norte da Sierra de Umango (Figura 9b). De oeste para leste, aparece o contato entre a Formação Punilla (Sierra de Las Minitas) e a ZCCP, seguido do perfil da ZCCP no Cerro Cacho, seção transversal por toda a Unidade Tambillo e, finalmente, o contato entre a Unidade Tambillo e a Unidade Tambillito.

O contato entre a Formação Punilla (Sierra de Las Minitas) e a ZCCP é delineado por falha transcorrente sinistral, como apresentado anteriormente. O padrão de dobramento antiforme/sinforme normal, de toda a seção, equivale a dobras D4. A dispersão dos pólos de planos S2 nos estereogramas da região do Cerro Cacho (Figura 9b - Estereograma A) e da região do Rio Umango (Figura 9b - Estereograma E) configura dobra cilíndrica (D4) com eixo de guirlandas construídas respectivamente, 160/18 e 185/07. As dobras D4 correspondem à principal estrutura deformadora da foliação principal S2 e possuem, na seção, meio comprimento de onda variando de 1,5 (ZCCP) até $6 \mathrm{~km}$ (norte do Barreal Grande/Rio Umango) e amplitude média de 1,5 km. Dobras flexurais foram descritas no ponto UM614, próximo ao Puesto Umango, associadas provavelmente à movimentação intercamadas nos flancos das dobras D4. 

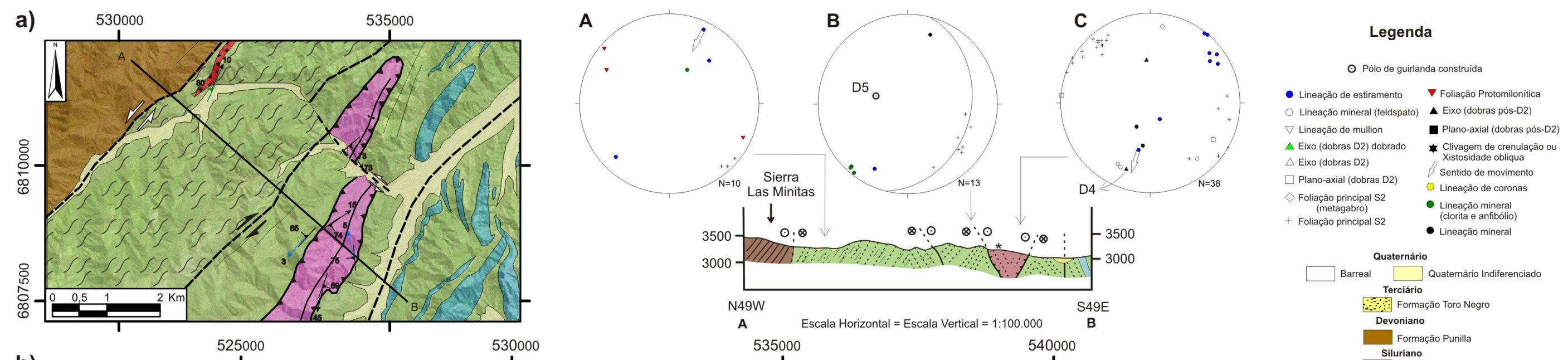

535000
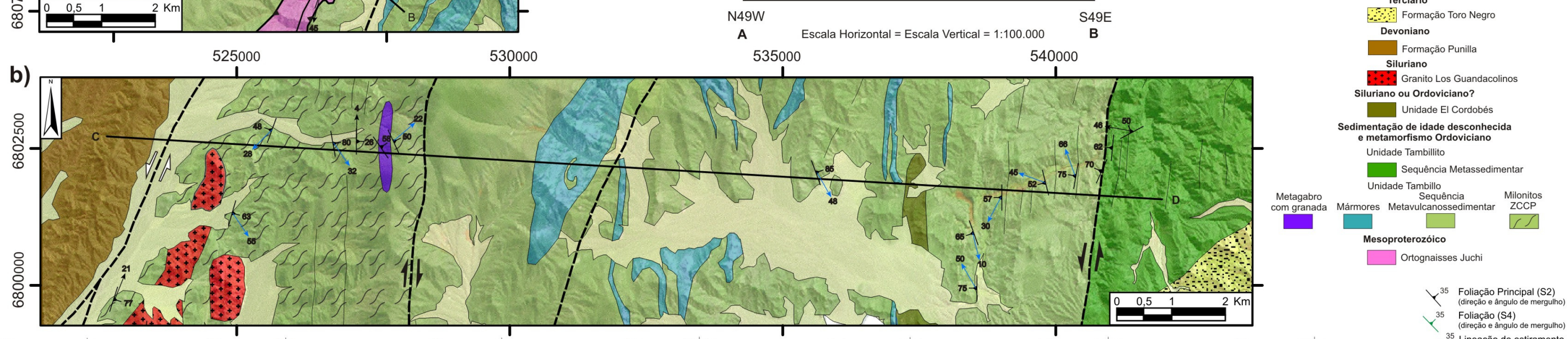

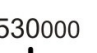
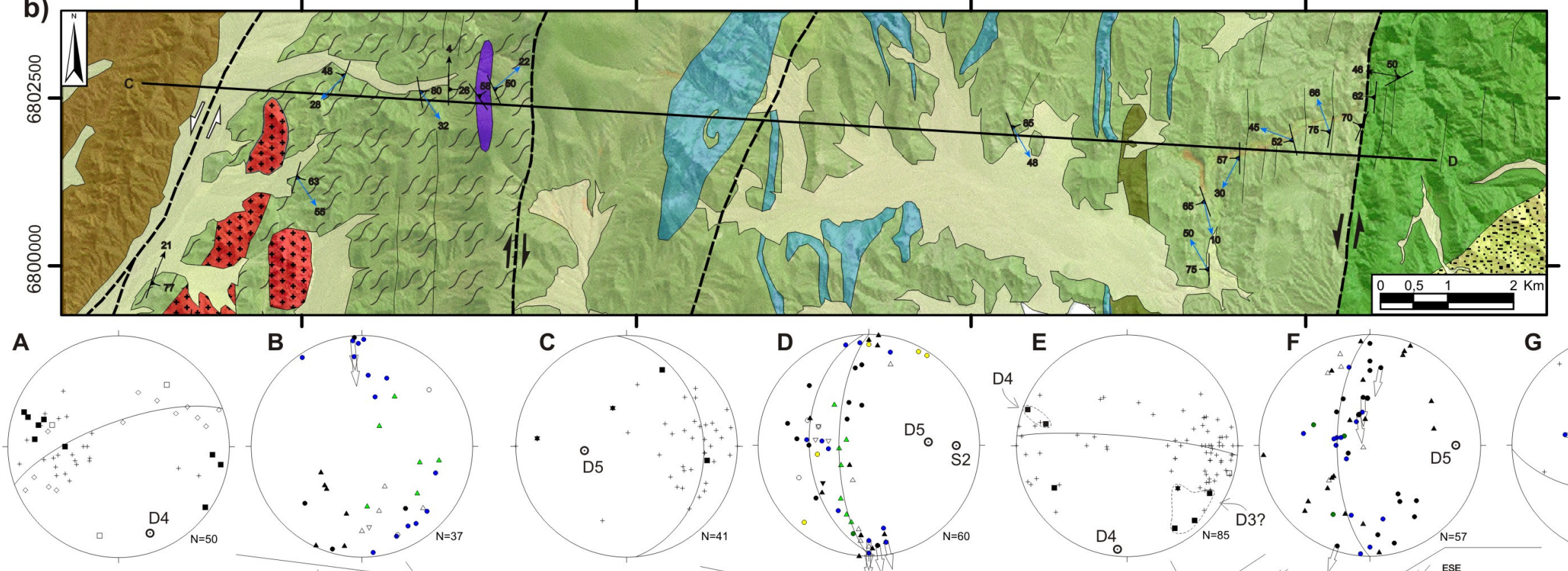

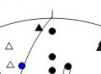

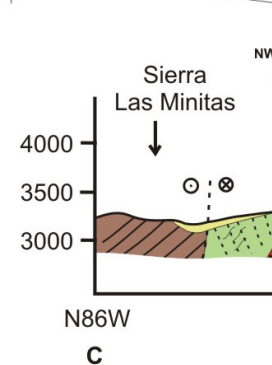

Nw Cerro Cacho
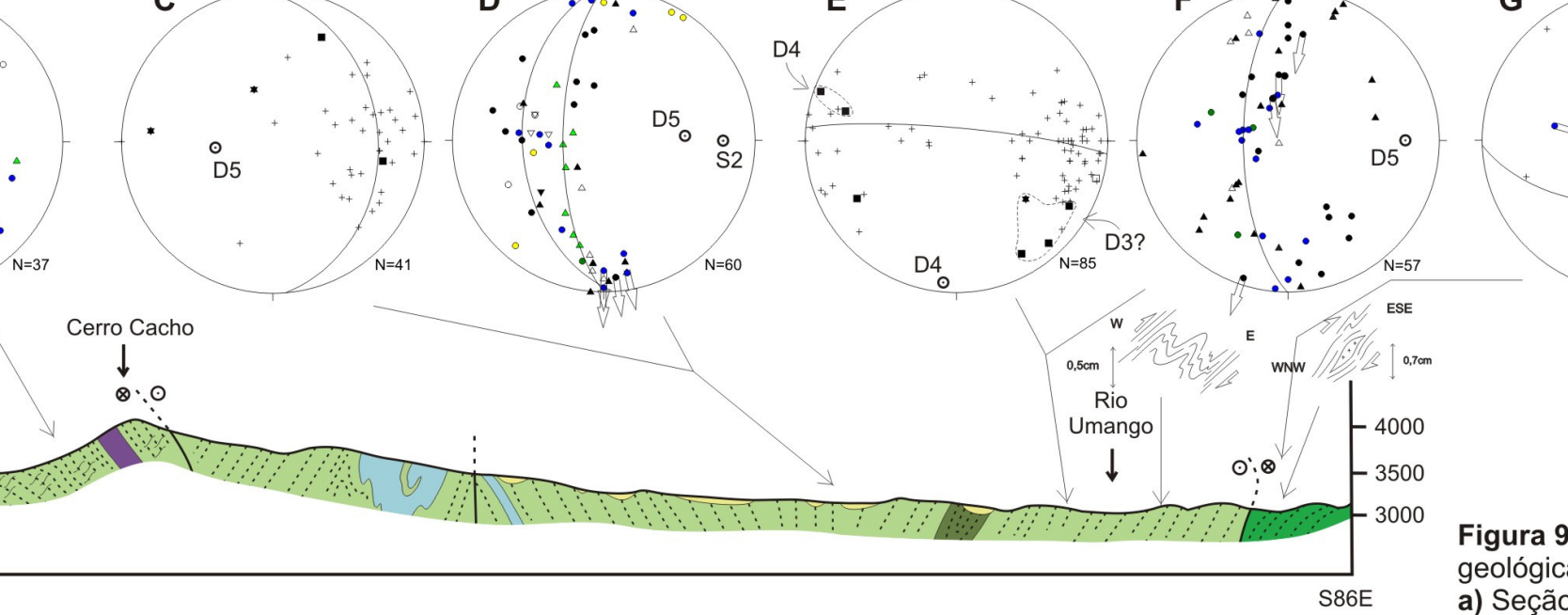

35 Foliaçăo Principal (S2)
(dirçąa e angullo de merguho)

$Y^{35} \begin{aligned} & \text { Foliaçăo (S4) } \\ & \text { (direcáo eangulo de mergulho) }\end{aligned}$

35 Lineaçäo de estiramento
(diresáa e angulo de caimentio)

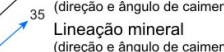

- Traģo da S2 e so

Foliaçăo Protomilonitica (S

$\because$ Foliaçäo Principal (S2)

$\angle$ Acamadamento (SO)

Eixo de Dobra
Sinformal (D4)

Zinistral (D2)

$\geqslant$ Zona de Cisalhamento

结 Zona de Cisalhamento

- - Falha Indefinida

- Falha de

A-B Seção Geológica

Figura 9: Mapas geológicos e seções

geológicas (1:100.000), e estereogramas.

a) Seção Geológica Água La Falda;

b) Seção Geológica Cerro Cacho-Rio Umango. 
Dobramentos pós-S2 foram descritos na seção transversal à ZCCP. As dobras observadas no ponto UM819 (desenho esquemático porção oeste da seção e Prancha XII - Fotos, 67, 68, 69 e 70) deformaram a foliação milonítica S2 e podem ser classificadas como dobras assimétricas, fechadas e inclinadas, do tipo 1C. Os planos axias medidos contêm direção NNE-SSW e alto ângulo de mergulho para W-WNW (Figura 9b - Estereograma A), os quais conferem vergência a E-ESE para essas estruturas. Outro conjunto de dobras analisado corresponde a estruturas que deformaram a foliação milonítica S2, próximo ao topo do Cerro Cacho (Pontos UM823a e UM823b). Trata-se de dobras apertadas (Prancha XI - Foto 66) a desarmônicas e em bainha (Ponto UM823b) com vergência para W e plano axial orientado NNE-SSW com alto ângulo de mergulho para E-ESE (Figura 9b Estereograma A). Os eixos medidos das dobras descritas concentram-se no quadrante SW, com caimento variando de 220/49 (Ponto UM819) a 205/02 (Ponto UM823a) (Figura 9b - Estereograma B). No ponto UM823b foram medidos eixos das dobras em bainha (triângulo verdes: Figura 9b - Estereograma B).

As estruturas descritas acima podem estar relacionadas à fase de dobramentos D3 ou ainda a dobras parasitas dos flancos das dobras D4. Entretanto, o estilo deformacional das dobras desarmônicas e em bainha é compatível com estruturas de deformação dúctil, superplástica, o que favorece a correlação com a fase D3.

Ainda na ZCCP, as lineações minerais e de estiramento sin-D2 apresentam orientação geral com caimento para N (baixo a médio ângulo) e SE (baixo ângulo) (Figura 9b - Estereograma B). Os indicadores cinemáticos observados sugerem transporte, preferencialmente, de topo para $S$, no entanto indicadores cinemáticos de topo para $\mathrm{N}$ também foram descritos. Os mullions $\mathrm{L} 2$ e eixos de dobras D2 estão orientados com caimento para S-SE de médio a baixo ângulo, subparalelo às lineações de estiramento.

Não há dados coletados na vertente leste do Cerro Cacho, porém a interpretação das imagens de satélite permitiu a identificação de espessa camada de mármore dobrada intrafolialmente (dobras D2) em estrutura sinformal. Falha indefinida inferida foi delineada a leste da espessa camada de mármore com base nos lineamentos da Quebrada La Pereza e drenagem a leste da "Klippe" Água La Falda, e nos truncamentos de camadas menos espessas de mármore.

Os estereogramas da porção central da seção (a norte do Barreal Grande) indicam a dispersão dos pólos de foliação S2, a qual define uma guirlanda com eixo construído de 265/59 (Figura 9b - Estereograma C). Os elementos lineares sin-D2 (eixos L2, lineações minerais e de estiramento) encontram-se dispersos em um grande círculo, também de rolo E-W (eixo construído 87/45) (Figura 9b - Estereograma D), 
segundo o dobramento posterior, isopaco e orientado ortogonalmente às lineações pretéritas. Esse dobramento foi correlacionado à última fase de deformação (D5). Os indicadores cinemáticos estudados sugerem transporte para sul.

Eixos medidos de dobra em bainha (triângulos verdes: Figura 9b Estereograma D) estão contidos em um círculo maior, representante do plano axial da dobra, que no caso, corresponde à foliação principal S2.

A relação estrutural entre a Unidade El Cordobés e a Unidade Tambillo apresenta-se inconclusiva, contudo na seção Cerro Cacho - Rio Umango aparentemente a unidade ocorre como uma dobra apertada no flanco leste de grande sinforma D4 e poderia representar dobras D3 ou dobras intrafoliais D2.

$\mathrm{Na}$ região do Rio Umango, a Unidade Tambillo contém dobras pós-S2, descritas como apertadas a fechadas, cilíndricas, com falhas associadas a rompimento de flanco (Ponto UM534) e dobras normais abertas a fechadas (Ponto UM539). As dobras observadas no ponto UM534 possuem planos axiais com rumo do mergulho de alto ângulo para NW, enquanto os planos axiais das dobras do ponto UM539 orientam-se com rumo do mergulho de alto ângulo para E-ESE (105/65 e 110/85) (Figura 9b - Estereograma E). As dobras analisadas no ponto UM539 possivelmente são correlatas a dobras D4, porém as estruturas do ponto UM534 poderiam ser associadas a dobras D3. Todavia, a correlação com dobras D4 é possível, se a dispersão dos pólos dos planos axiais for associada a um dobramento posterior (D5). Essa dispersão também é observada, secundariamente, nos pólos da foliação S2 (Figura 9b - Estereograma E).

No Rio Umango, as estruturas lineares sin-D2 e pós-D2 ocorrem dispersas e contidas em um círculo maior com eixo construído 90/24 (Figura 9b - Estereograma F), provavelmente associado também a dobramento posterior, isopaco e orientado ortogonalmente à lineações pretéritas. Os eixos medidos de dobras pós-D2, inclusive dobras abertas prováveis D4, levam à interpretação de que esse dobramento corresponda à fase D5. Eixos de dobras orientados NE-SW poderiam estar relacionados a dobras D3 (Figura 9b - Estereograma F). O sentido de transporte associado às lineações minerias (sin-D2) foi caracterizado por estruturas em pares $\mathrm{S} / \mathrm{C}$ e indicadores cinemáticos, que conferiram movimento de topo para $\mathrm{S}$.

O contato entre as unidades Tambillo e Tambillito é caracterizado por falha transcorrente sinistral com componente inverso para SE. A cinemática desse contato e de todo o pacote rochoso incluso na porção leste da Unidade Tambillo e oeste da Unidade Tambillito foi identificada em pares S/C, sigmóides quartzo-feldspáticos, dobras assimétricas e dobras intrafoliais descritas ao longo do Rio Umango e arredores (ver desenhos esquemáticos na porção leste da seção). 
Os dados obtidos na Unidade Tambillo sugerem uma dispersão dos pólos de foliação S2 em uma guirlanda de eixo construído 358/35 (Figura 9b - Estereograma G). Os eixos medidos de dobras abertas possuem grande correlação com o eixo construído e o pólo do plano axial medido está contido na guirlanda. Com essas relações podemos interpretá-las como correlatas à fase D4, com eixo aproximadamente N-S e plano axial com rumo do mergulho de alto ângulo para NW. Seta com indicação de sentido de movimento, associado a pares $S / C$ e lineação de estiramento, indica transporte de topo ESE (Figura 9b - Estereograma G).

\subsubsection{Seção Los Guandacolinos}

A seção geológica Los Guandacolinos apresenta a estruturação da Formação Punilla (Sierra de La Punilla), das rochas carbonáticas da Sequencia La Troya, rochas metassedimentares milonitizadas da ZCCP e do Granito Los Guandacolinos (Figura 10a).

Parte da geometria de deformação que afetou as rochas sedimentares Paleozóicas (Devoniano Superior) da Sierra La Punilla é apresentada na porção oeste da seção (Figura 10a). A dispersão dos pólos de estratificação é compatível com um padrão sanfonado de dobras (Figura 10a - Estereograma A). O eixo construído destas dobras possui caimento moderado para SW (228/47), coincidente com lineação de intersecção medida (225/25).

A estratificação e xistosidade $\mathrm{S} 1$ da Sequencia Carbonática La Troya apresentam, em estereograma, uma dispersão polar semelhante à das rochas sedimentares La Punilla, mas orientada para NE (044/25), próximo dos eixos medidos (Figura 10a - Estereograma B). As clivagens medidas não pertencem a esse dobramento.

A oeste do Granito Guandacolinos a disposição polar das superfícies S2 sugerem dois padrões de dobras cilíndricas com eixos no quadrante SW (Figura 10a Estereograma C). O padrão mais preservado orienta-se 199/15 e pode ser associado a dobras de eixo N-S (D4). Os planos axiais medidos, orientados com rumo do mergulho de ângulo moderado para $W$, estão contidos na guirlanda construída $e$ podem corresponder aos planos axiais das dobras D4. O segundo padrão de dispersão, orientado 239/60, contempla também a dispersão das superfícies S4 (planos axiais de D4), possibilitando a relação deste com dobramentos tardios (D5). Os eixos medidos estão orientados NW-SE com caimento para ambas as direções.

As lineações minerais e de estiramento sin-D2 encontram-se preferencialmente orientadas N-S, com concentração de caimento subhorizontal para N-NNE (Figura 
10a - Estereograma D). Os eixos de dobras intrafoliais D2 apresentam-se subparalelas às lineações minerais e de estiramento. Os indicadores cinemáticos apontam para movimentos de transporte para $S$, porém também foram observados indicadores de movimento para $\mathrm{N}$.

No Granito Los Guandacolinos, parte dos dados coletados corresponde a estruturas em xenólitos metassedimentares. A principal estrutura deformacional no Granito Los Guandacolinos corresponde a uma foliação protomilonítica com orientação média de mergulho 289/66, coincidentes com a orientação geral dos planos axiais de D4 (Figura 10a - Estereograma E). As lineações minerais e de estiramento, os eixos de dobras D2 e pós-D2 foram coletados nos xenólitos metassedimentares (Figura 10a - Estereograma F). A seta com indicação de transporte está associada a um indicador cinemático e lineação de estiramento de milonito da ZCCP.

\subsubsection{Seção Barreal Chico - Puesto Tambillito}

Na seção Barreal Chico - Puesto Tambillito, localizada na região central da Sierra de Umango, observa-se, de oeste para leste, sinforma contendo a Unidade El Cordobés, Unidade Tambillo, com Granito El Peñon intercalado, e contato entre as unidades Tambillo e Tambillito (Figura 10b).

Dois padrões cilíndricos de dispersão polar de S2 foram identificados no estereograma da região do Barreal Chico (Figura 10b - Estereograma A). O padrão com maior número de dados corresponde a uma guirlanda com eixo construído 01/50. Esse eixo seria compatível com a estrutura sinformal normal, de orientação N-S, observável no desenho da Unidade El Cordobés na seção. O segundo padrão orientase (eixo construído) 231/45. Esse padrão estaria concordante com as estruturas medidas em dobras abertas, com eixo de alto ângulo de caimento para W-SW e plano axial com rumo do mergulho de alto ângulo para WNW (Figura 10b - Estereograma A). O primeiro padrão é interpretado como produto do dobramento D4 e o segundo associado ao dobramento D5.

Após a Unidade El Cordobés, espessa camada de terraços quaternários recobre as unidades metamórficas e ígneas da Sierra de Umango, até os afloramentos da região do Puesto Tambillito. A estrutura das rochas do substrato foi interpretada com base na continuidade das estruturas verificadas na seção Puntilla - La Champa, a sul. 
a)

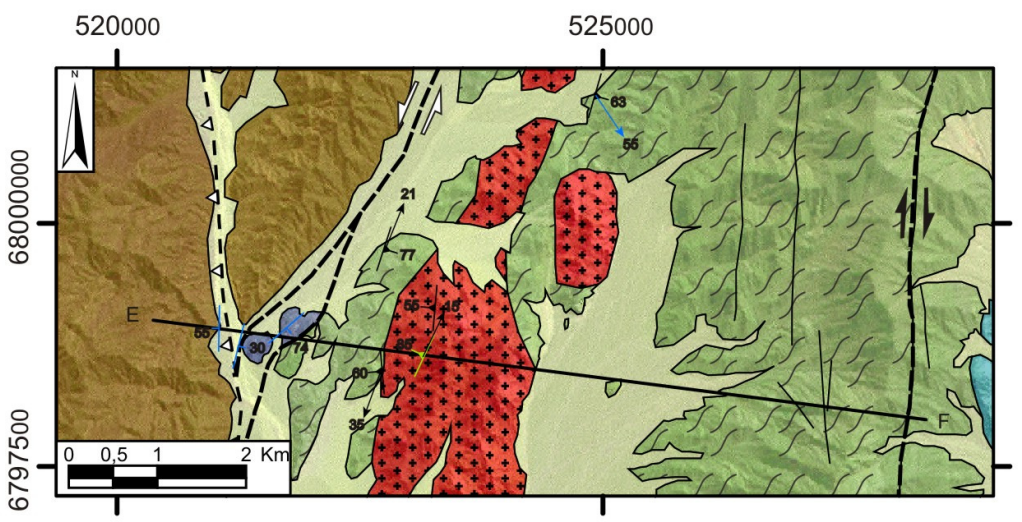

A

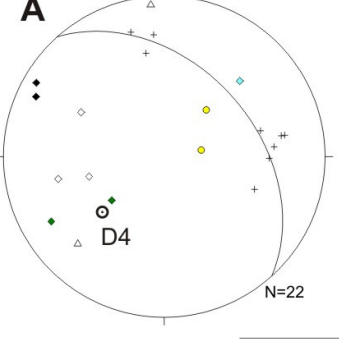

B

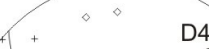

veio de quartzo $\Delta$ Eixo B (crenulaçä)

- Falha

Fratura

$\diamond$ Clivagem

$\triangle$ Lineaçāo de intersecçâa

Estrias

Dique de rocha
subuvucânica ácida
a intermediária

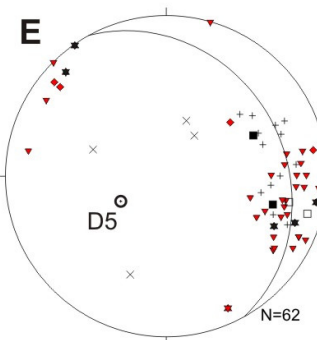

D $\therefore \therefore \therefore$
F $\frac{1}{\Delta_{0} \Delta}$

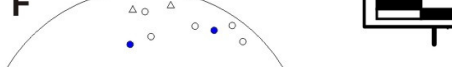

A.

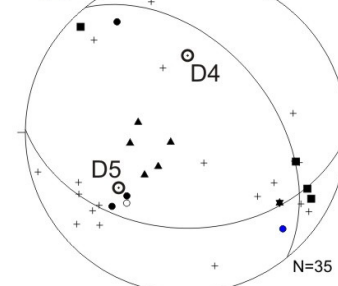

$\odot^{\mathrm{D} 5}$

$\odot^{\mathrm{D} 4}$

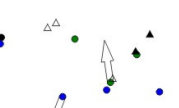

. 18

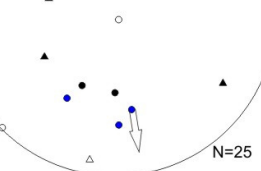

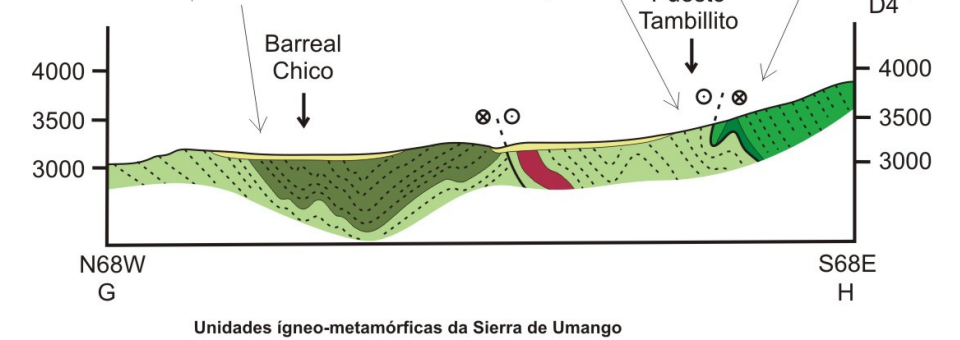

b) 530000

各

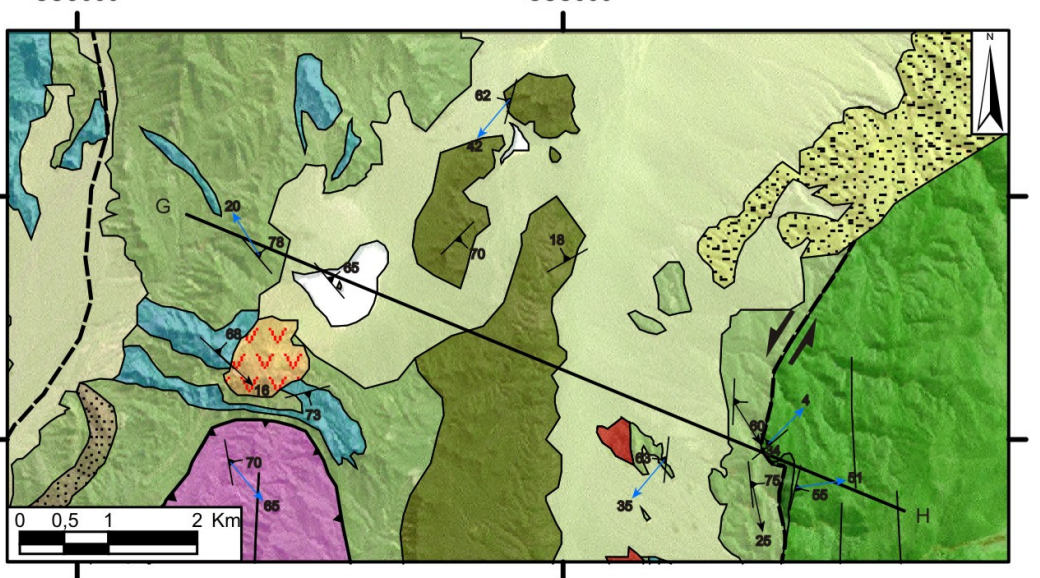

$C$

C
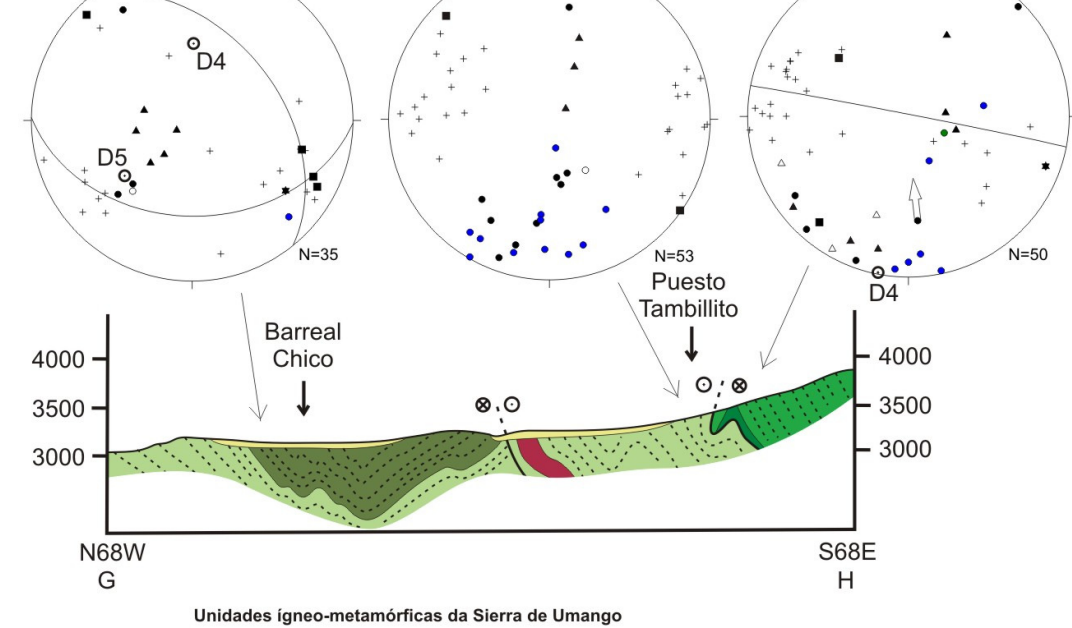

- Lineaçăo mineral

- Lineação de estiramento

L Lineação mineral ffeldspato

Sentido de movimentas

Lineação mineral (feld

Eixo (dobras D2)

๑ Pólo de guirlanda construida

+ Foliaçăo principal S

- Eixo (dobras pós-D2)

- Falha

- Clivagem de crenulação ou $\quad \nabla$ Foliaçāo protomilonitica

(clortat e anfibolio)

N82W

Figura 10: Mapas geológicos e seções

geológicas (1:100.000), e estereogramas.

a) Seção Geologica Los Guandacolinos:

b) Seção Geológica Barreal Chico-Puesto Tambillito.

\section{S82E}

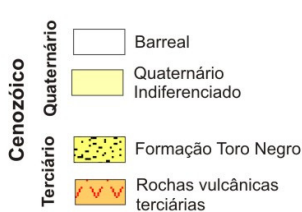

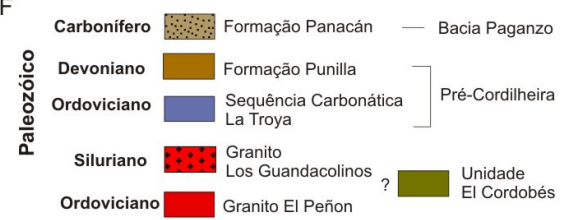

sedi

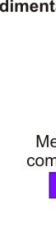

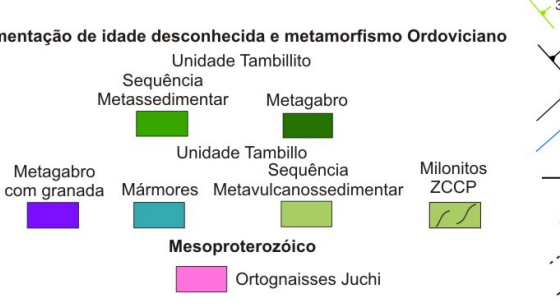

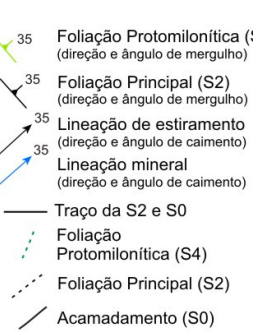

$\uparrow$ Exixo de Dobra

Sinistral (D2)

그 Zona de Cisalhamento

는ona de Cisalha

Fander

- Falha de Cavalgamento (D2)

$-\triangle$ Falha de Cavalgamento 
Na região do Puesto Tambillito aflora o contato entre as unidades Tambillo e Tambillito. A Unidade Tambillo possui dois grupos de orientação polar da superfície S2, aparentemente associado a flancos de dobras NNE-SSW (Figura 10b Estereograma B). Essas estruturas podem ser observadas no desenho da foliação S2 na seção e as estruturas medidas (planos axiais e eixos de dobras abertas e crenulação) possuem orientações concordantes. Com essas observações, pode-se relacionar as dobras medidas em campo com as dobras D4. Padrão de dispersão posterior N-S (D5?), parece modificar a orientação de S2 e dos eixos D4 (Figura 10b

- Estereograma B). As lineações minerais e de estiramento concentram-se nos quadrante SW e SE, de alto a baixo ângulo de caimento.

O contato entre as unidades metassedimentares Tambillo e Tambillito corresponde a uma falha sinistral dobrada. A falha sinistral seria paralela às estruturas principais S2, associada à fase D2 e teria sido dobrada pelos dobramentos posteriores.

A Unidade Tambillito nesta região apresenta pelo menos dois dobramentos que modificaram a orientação de S2. Em estereograma é possível identificar um padrão de dispersão polar de S2, orientado 191/01 e outro N-S menos expressivo (Figura 10b Estereograma C). As medidas coletadas definem as estruturas $\mathrm{N}-\mathrm{S}$ e estruturas $\mathrm{E}-\mathrm{W}$, respectivamente interpretadas como D4 e D5. As lineações minerais e de estiramento orientam-se, preferencialmente, com caimento para $S$, e um indicador cinemático de pares S/C (Ponto UM532) sugere movimentação de topo para N.

\subsubsection{Seção La Puntilla - La Champa}

A seção geológica La Puntilla - La Champa corta a porção sul da Sierra de Umango (Figura 11) e permite a visualização de grande parte do cenário estrutural da serra. De oeste a leste, cruza a ZCCP no Cerro Puntilla, atravessa extenso depósito quaternário da Quebrada La Pereza, rochas sedimentares da Formação Panacán (Bacia Paganzo), até alcançar as rochas da Unidade Tambillo na seção da Água Amarilla. $\mathrm{Na}$ drenagem da Água Amarilla observa-se o contato entre a Unidade Tambillo e os Ortognaisses Juchi. Os Ortognaisses Juchi apresentam-se sobrepostos à Unidade Tambillo em uma estrutura sinformal. A leste dessa estrutura sinformal ocorre ainda a Unidade El Cordobés e seção ao longo da Quebrada La Champa na Unidade Tambillo até o Granito El Peñon.

A estrutura principal observada na seção corresponde a dobras abertas normais pós-S2, elucidada, por exemplo, pela sinforme composta pelos Ortognaisses Juchi na porção central da seção geológica. 
Na região do Cerro Puntilla (ZCCP) a dispersão dos pólos de S2 (foliação milonítica) sugere um dobramento cilíndrico com eixo construído de caimento para $S$ (189/32) (Figura 11 - Estereograma A). Plano axial de dobra aberta (pós-S2), com pólo contido na guirlanda construída, tem mergulho de alto ângulo para W (262/63) e associa-se a dobras com eixos de caimento para S (Figura 11 - Estereogramas A e $B)$. Essas dobras foram relacionadas a dobras D4 orientadas N-S, vinculadas às principais estruturas que controlam a disposição atual das superfícies S2. Eixos e clivagens de crenulação (pós-S2) coletados nos milonitos encontram-se orientados diferentemente das estruturas tidas como D4, e possivelmente estão associados a estruturas D3 ou D5.

As lineações minerais e de estiramento (sin-D2) apresentam-se, aparentemente, agrupadas em dois grupos distintos (Figura 11 - Estereograma A). As lineações associadas a transporte para $S$ estão contidas em um pequeno círculo com geratriz orientada com caimento de alto ângulo para NNW. O conjunto de lineações orientadas NE-SW e ENE-WSW indicam transporte para leste e não devem corresponder ao mesmo processo do primeiro conjunto. Para a caracterização do transporte foi utilizado os indicadores cinemáticos observados em campo (Prancha XIII - Fotos 73 e 74) e indicadores cinemáticos microestruturais (ver Microtectônica).

A seção geológica levantada pela drenagem denominada Água Amarilla permitiu o acesso ao contato entre a Unidade Tambillo e os Ortognaisses Juchi. As rochas da Unidade Tambillo apresentam dobras pós-S2 caracterizadas por dobras abertas a fechadas, inclinadas e isopacas (subclasse 1B) (Prancha XIII - Foto 75) com freqüentes falhas de empurrão associadas. A dispersão polar da superfície S2 sugere um dobramento aparentemente cilíndrico com eixo construído NE (38/22) (Figura 11 Estereograma C), coincidente com os eixos medidos em campo (Figura 11 Estereograma D). Os planos axiais e xistosidade oblíqua medidos aparecem contidos na guirlanda construída, com direção variando de N-S a NW-SE e mergulho para E a NE respectivamente. O dobramento cilíndrico descrito pode estar relacionado a dobras D4 (planos axiais com rumo do mergulho de alto a moderado ângulo para E), desenhadas no perfil como dobras assimétricas inclinadas, vergentes para W, associada à falha de cavalgamento. A xistosidade oblíqua orientada NW-SE com mergulho de baixo ângulo para NE e planos axiais que mergulham em alto ângulo para NE poderiam ser associados a dobramento anterior (D3) com eixo medido de orientação 330/20 e 322/11 (Ponto UM504 - Figura 11 - Estereograma D).

Dobra intrafolial de mármore foi mapeada por interpretação da imagem de satélite e aparece como dobra D2 na seção. Os elementos lineares sin-D2 
concentram-se no quadrante NE, com pares S/C que sugerem movimentação de topo para SW.

$\mathrm{Na}$ base da sinforme desenhada pelos Ortognaisses Juchi (Água Amarilla) observa-se uma região de intensa deformação e transposição da foliação principal S2. A foliação de transposição pós-S2 está associada ao rompimento de dobras apertadas vergentes para W. Essa foliação foi interpretada como correspondente à foliação S3, embora a orientação N-S e o mergulho de alto ângulo para E permitam relacioná-las a dobras D4. A dispersão dos pólos de S2 sugere o mesmo padrão cilíndrico de dobramento (D4) observado na Unidade Tambillo, com eixo construído ENE (16/33) (Figura 11 - Estereograma E). A orientação dos eixos medidos varia de NE a NW (Figura 11 - Estereograma F) e os planos axiais observados possuem rumo do mergulho de alto ângulo para NE.

Na porção leste dos Ortognaisses Juchi (Quebrada La Champa) observam-se dobras pós-S2 assimétricas e inclinadas com vergência para E (Prancha XIII - Foto 76). As dobras observadas em campo possuem planos axiais com mergulho de alto ângulo para SW e SE (Figura 11 - Estereograma G). A dispersão polar de S2 sugere um dobramento cilíndrico (D4) de eixo construído (328/62), coincidente com os eixos de dobras medidos (Figura 11 - Estereograma $\mathrm{H}$ ). Os planos axiais com mergulho para SW seriam compatíveis com o desenho das dobras na seção e consequentemente associados à mesma fase da sinforma maior. Já os planos axiais com mergulho para SE corresponderiam a dobramentos anteriores (D3) ou posteriores (D5).

As dobras assimétricas observadas nas rochas da seção ao longo da Água Amarilla (vergentes para W) e nas rochas do embasamento na Quebrada La Champa (vergentes para E) podem ser interpretadas como dobras parasitas dos flancos de dobra sinfomal associada ao dobramento flexural (D4). A sinforme D4, delineada pelos Ortognaisses Juchi, define a "Klippe Juchi".

A Unidade El Cordobés aparece a leste dos Ortognaisses Juchi em estrutura sinformal aparentemente sobreposta à Unidade Tambillo. Essa sinfome pode ser associada ao dobramento D3 ou D4. Há poucos dados estruturais coletados neste setor (Figura 11 - Estereograma I), entretanto cabe ressaltar os eixos medidos com caimento subhorizontal para NNW.

No leste da seção é possível observar a estrutura maior antiformal (D4) com dobras assimétricas vergentes para $\mathrm{W}$ com falhas de cavalgamento associadas. A dispersão dos pólos de S2 indica um dobramento cilíndrico com eixo construído 172/28, coincidente com os eixos de dobras medidos (Figura 11 - Estereogramas J e K). Os planos axiais medidos de orientação N-S e mergulho de alto ângulo para W e E 
podem estar relacionados ao dobramento cilíndrico, e a variação de mergulho pode ser explicada pela orientação da clivagem plano axial em leque. Os eixos E-W também foram observados (Figura 11 - Estereograma K) e podem estar associados a dobras posteriores (D5). As lineações minerais e de estiramento (L2) concentram-se orientadas N-S, porém a orientação NW-SE também ocorre (Figura 11 Estereograma K)

O padrão cilíndrico do dobramento D4 pressupõe uma disposição subhorizontal para a foliação S2 e para a klippe e um dobramento D3 quase recumbente, possivelmente vergente para W. A variação na superfície S2, pós-dobramento D3, assinalam a variação e os caimentos moderados dos eixos construídos das dobras D4.

\subsubsection{Microtectônica}

Microestruturas em rochas metamórficas representam o produto final de uma complexa história que pode envolver seqüências de reações químicas e repetidos eventos deformacionais (Vernon, 2004). Evidências microscópicas são usadas para inferir a história metamórfica e deformacional das rochas, portanto cuidados devem ser tomados na tentativa de não extrair mais informação do que as evidências permitem, considerando sempre a possibilidade de interpretações alternativas e grande complexidade dos processos envolvidos (Vernon, 2004).

As microestruturas que serão apresentadas a seguir representam principalmente as evidências de deformações dúcteis na ZCCP, texturas metamórficas e estruturas características das unidades mapeadas, suas relações temporais e associações com as fases deformacionais descritas anteriormente.

As foliações metamórficas definidas anteriormente são reconhecidas nas lâminas delgadas das unidades mapeadas na Sierra de Umango. Relíquias das foliações S1 podem ser observadas como foliação interna em porfiroblastos de granada (Unidade Tambillo - Prancha XIII - Fotos 77 e 78) e trilhas de opacos e quartzo em porfiroblastos de estaurolita (Unidade Tambillito - Prancha VII - Fotos $41 \mathrm{e}$ 42), ambos intercinemáticos, sugerindo um padrão metamórfico e e deformacional contínuo entre S1 e S2. 
Legenda

$\odot$ Pólo de guirlanda construida

- Lineacão mineral
(clorita a anfibólio)

- Lineaçăo mineral

- Lineação de estiramento

Lineação mineral (feldspato) * Clivagem de crenulação ou

$\checkmark$ Lineaçăo de mullion

"Sentido de movimentaçăa

$\triangle$ Eixo (dobras D2)

Plano-axial (dobras D2)

+ Foliação principal S2

A
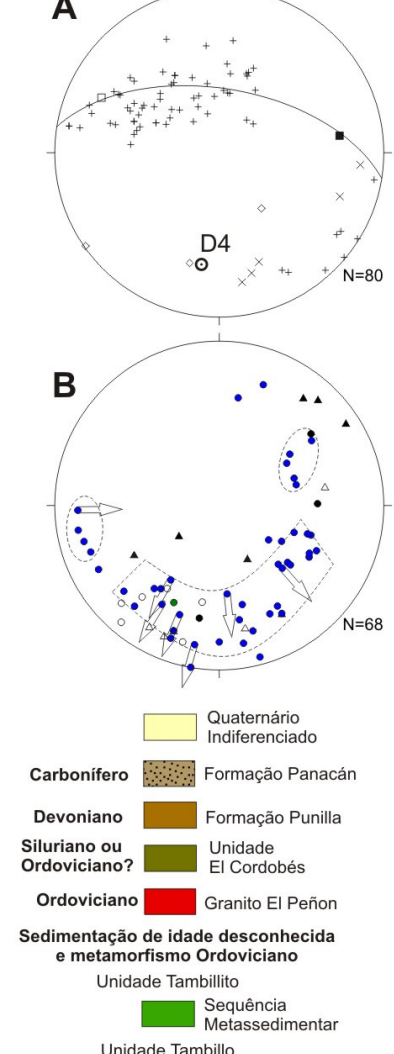

Sequência
Metagabro Milonitos
com granada Mármores Metavulcanossedimentar Mesoproterozóico $\square$ Ortognaisses Juchi

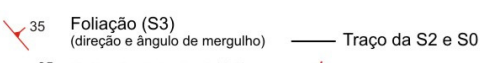

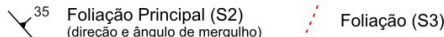

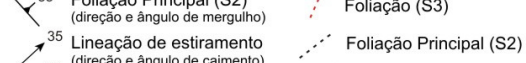

Lineação mineral
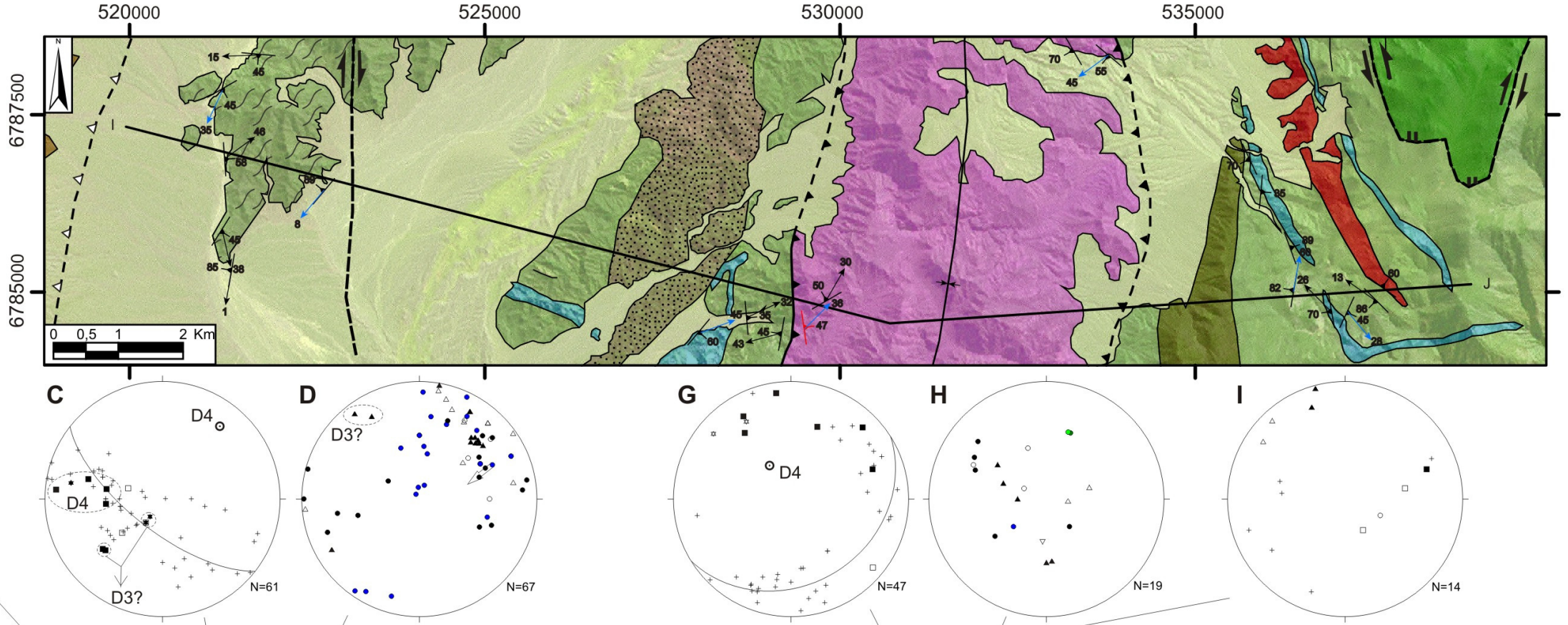

G

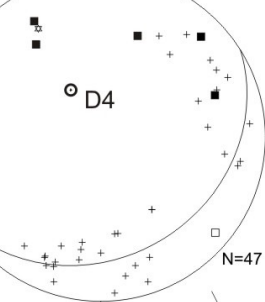

E
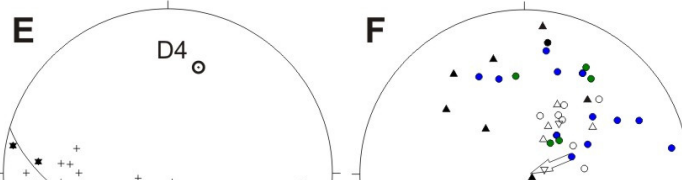

$\underbrace{++}_{+}$

$+4$
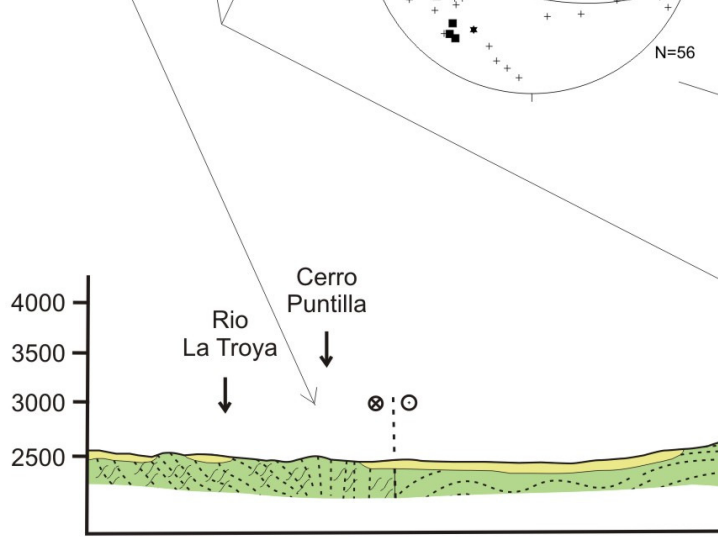

N75W

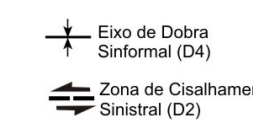

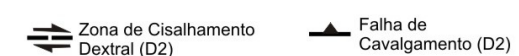

$-\Delta$ Falha de Cavalgamento

A-B Seção Geológica

Figura 11: Mapa geológico e seção

geológica (1:100.000), e estereogramas

Seção Geológica Cerro Puntilla-Quebrada La Champa 
Uma grande variedade de associações minerais compõe a foliação metamórfica principal S2 nas diferentes unidades geológicas descritas. Associações minerais caracterizadas por intercalações de bandas de espessura milimétrica lepidoblásticas, ricas em biotita e muscovita, e granoblásticas, ricas em quartzo e, muitas vezes, plagioclásio, ocorrem com freqüência nos metapelitos e metagrauvacas das unidades Tambillo e Tambillito (Prancha VII - Fotos 41 e 42; Prancha XIV - Fotos 79, 80, 81 e 82). Tramas granoblásticas são freqüentes principalmente nas rochas calciossilicáticas da Unidade Tambillo, compostas por quartzo, carbonato, anfibólio, granada, minerais do grupo do epidoto e titanita (Prancha V - Fotos 29 e 30), e são caracterizadas por bandamento descontínuo, marcado pela variação das proporções minerais (Prancha XIV - Fotos 83 e 84).

Nos Ortognaisses Juchi a principal característica de S2 associa-se ao bandamento tabular composicional, identificado nos gnaisses como bandas quartzofeldspáticas e bandas ricas em biotita e/ou hornblenda, e nas metabásicas como bandas ricas em anfibólio (hornblenda), por vezes, granada, e bandas ricas em plagioclásio e quartzo (Prancha II -Fotos 7 e 8). As rochas metabásicas descritas no perfil Água La Falda, possuem associação mineral de clinopiroxênio (diopsídio), granada, anfibólio (hornblenda), rutilo, titanita, ilmenita, quartzo e plagioclásio. A paragênese granada, diopsídio, rutilo e quartzo, na ausência de plagioclásio (Prancha II - Fotos 9 e 10), permite inferir condições metamórficas de transição entre a fácies granulito de alta pressão e eclogito de média temperatura (González et al., 2005 e Campos Neto et al., in prep.).

Evidências de deformações dúcteis foram observadas nas rochas da ZCCP. Feições como dobras kink em minerais tabulares (sillimanita e cianita) (Prancha VI Fotos 31 e 32), lamelas de deformação e extinção ondulante em grãos de quartzo, e geminação induzida por deformação em plagioclásio (Prancha VI - Fotos 33, 34 e 35) determinam a presença de deformação dúctil, principalmente associada a fluxo plástico em cristais ("crystal plastic flow") (Vernon, 2004). Processos de recristalização do tipo "bulging" e rotação de subgrãos nos minerais de quartzo (Prancha VI - Foto 36) também foram observados. Porfiroclastos de feldspato (plagioclásio, feldspato potássico e pertita) e granada são freqüentes nas rochas de composição granítica e semi-pelíticas/"wackes". Porfiroclastos de anfibólio e clinopiroxênio são verificados nas rochas de composição básica (Prancha VI - Fotos 33 e 34).

Lâminas delgadas orientadas segundo a lineação de estiramento foram utilizadas para a determinação de sentido de movimentação da deformação principal (D2) nas rochas estudadas. O enfoque foi dado às rochas miloníticas observadas na 
área de estudo, com determinação de condições metamórficas de formação de cada zona de cisalhamento.

As rochas da ZCCP apresentam assembléias minerais compostas por aluminossilicato (sillimanita e cianita), biotita, granada, feldspato $\mathrm{K}$, quartzo, rutilo e plagioclásio nas metagrauvacas, e anfibólio, clinopiroxênio, plagioclásio, quartzo e opacos nas metabásicas. Essas assembléias minerais sugerem condições de alto grau metamórfico em fácies granulito de alta pressão (em presença de cianita nos semi-pelitos). As microestruturas observadas nesses litotipos demonstram condições de recristalização dinâmica em mais baixas temperaturas (tipo "bulging" e rotação de subgrãos em quartzo, por exemplo), indicando que a fase de milonitização registrada nessas rochas pode ser datada relativamente como pós-pico metamórfico e tardi-fase de deformação D2.

Os indicadores cinemáticos observados nas rochas da ZCCP demonstram sentido de movimento para S (Prancha VII - Fotos 37 e 38), corroborando com os indicadores cinemáticos observados em campo (Prancha XIII - Foto 74).

A lâmina delgada descrita do Granito El Peñon (UM612) demonstra textura porfiroclástica definida por sigmóides quartzo-feldpáticos envolvidos por bandas lenticulares descontínuas de hornblenda e opacos, definindo estruturas S/C e C' (Prancha VIII - Fotos 43 e 44).

Dobras pós-S2 foram observadas também em lâmina delgada, as quais estão preservadas nas intercalações entre bandas lepidoblásticas (ricas em biotita e muscovita) e bandas granoblásticas (ricas em quartzo) dobradas, com flancos assimétricos e formação incipiente de foliação plano-axial com neocristalização de biotita e muscovita (Prancha V - Fotos 27 e 28).

O granitóide deformado, descrito no ponto UM616, corresponde a um muscovita-clorita-quartzo-feldspato protomilonito com porfiroclastos feldspáticos indicando movimentação de transporte no sentido contrário ao caimento da lineação de estiramento (Prancha IX - Fotos 49 e 50), definindo cinemática sinistral com incipiente componente inverso para essa deformação. As condições de metamorfismo durante a deformação protomilonítica descrita ocorreram em baixo grau metamórfico com cristalização de clorita, muscovita e opacos nas estruturas S/C, assim como microestruturas do tipo "bulging" e rotação de subgrãos/extinção ondulante nos minerais de quartzo (Prancha IX - Fotos 49 e 50). 


\section{Prancha XIII}
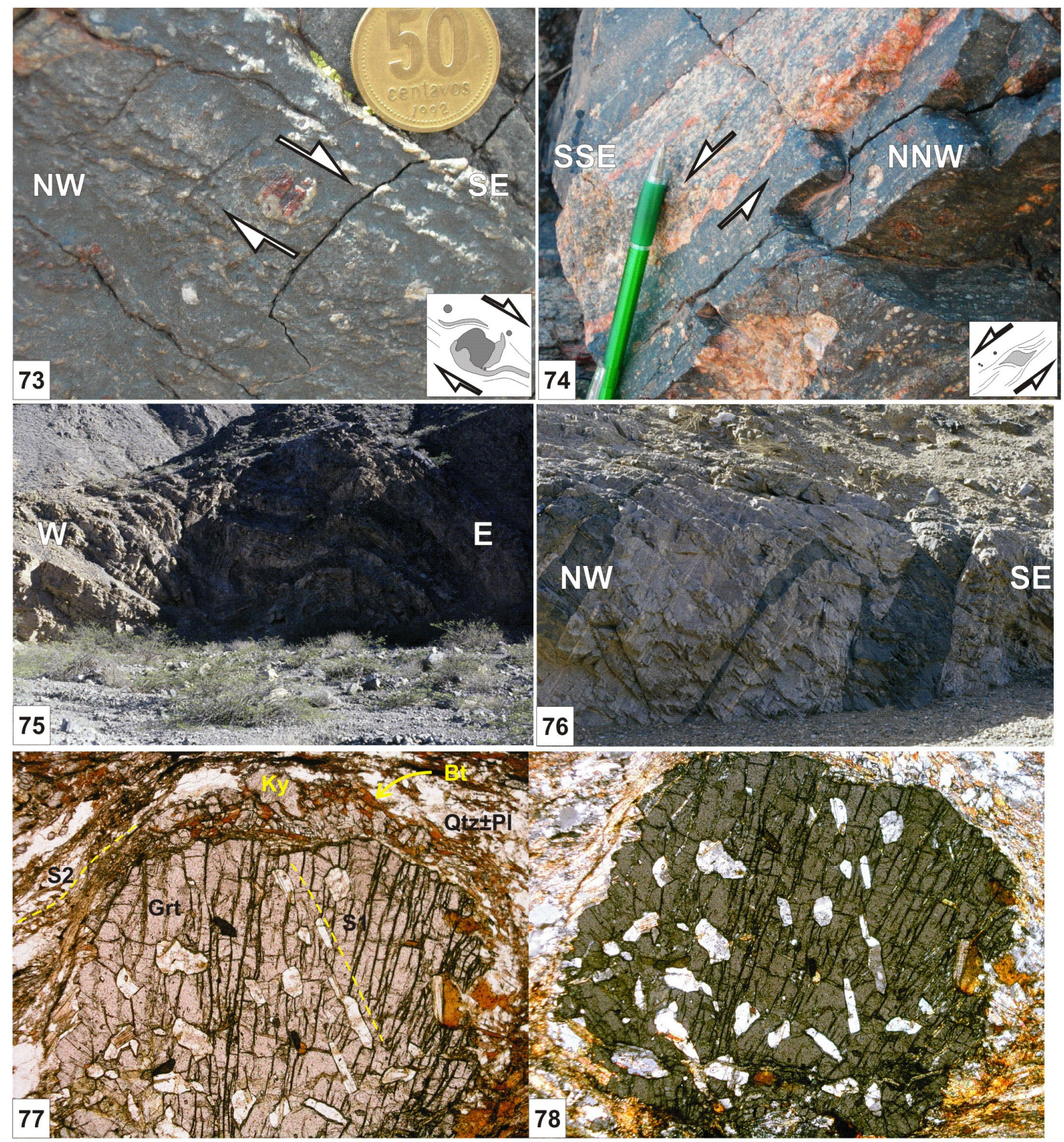

Foto 73: Indicador cinemático do tipo delta, formado por granada e quartzo, indicando abatimento da capa para SE. ZCCP, Ponto UM604.

Foto 74: Indicador cinemático tipo sigma formado por porfiroclasto de feldspato potássico, sugerindo o abatimento da capa para SSE. ZCCP, Ponto UM608.

Foto 75: Dobras fechadas, assimétricas e inclinadas pós-D2 em intercalações entre camadas de mármore, rochas calciossilicáticas, anfibolito e biotita xisto com granada. Quebrada Água Amarilla, Unidade Tambillo, Ponto UM504.

Foto 76: Biotita gnaisse com bandas irregulares (em "pitch-and-swell") feldspáticas de espessura centimétrica e rocha metabásica intrusiva apresentam-se dobradas, definindo dobra fechada e inclinada pós-D2. Quebrada La Champa, Ortognaisses Juchi, Ponto UM528.

Foto 77: Fotomicrografia da foliação interna S1 em porfiroblasto de granada delineada por inclusões de quartzo e plagioclásio. Intercalações entre bandas de espessura submilimétrica nematolepidoblásticas (ricas em biotita e cianita) e granoblásticas (ricas em quartzo e plagioclásio) marcam foliação principal S2, a qual engloba o porfiroblasto de granada. Unidade Tambillo, Amostra UM624A. Foto com nicóis paralelos e lado maior igual a 3,2mm.

Foto 78: Idem à foto 77 com analisador inserido. 


\section{Prancha XIV}

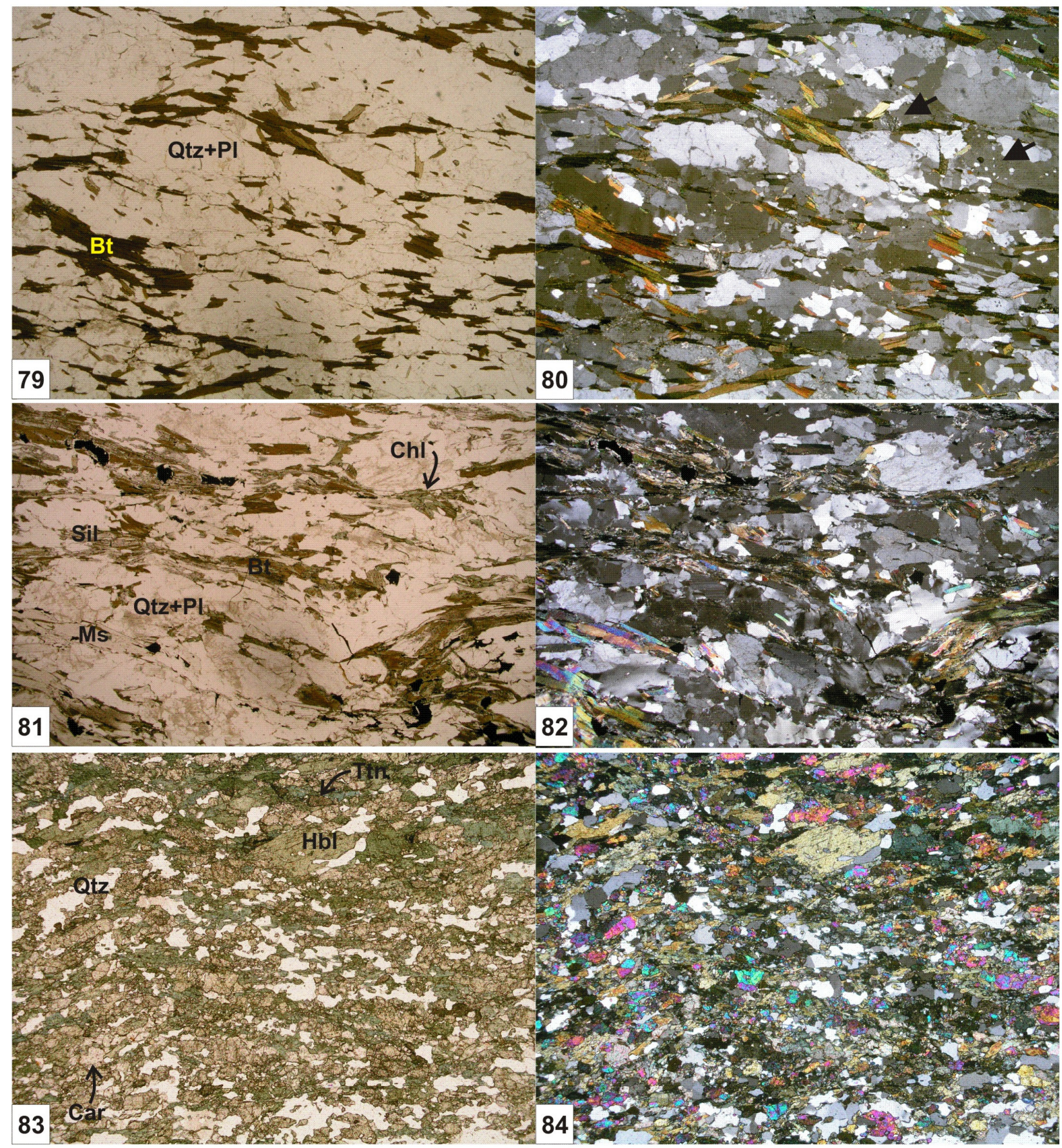

Foto 79: Fotomicrografia de bandas lepidoblásticas descontínuas de biotita e bandas granoblásticas ricas em quartzo e plagioclásio, as quais definem a foliação principal S2. Mirmerquitas e inclusões arredondadas de quartzo em plagioclásio ocorrem nas bandas granoblásticas (indicadas pelas setas). Unidade Tambillo, Amostra UM655. Foto com nicóis paralelos e lado maior igual a $8,2 \mathrm{~mm}$.

Foto 80: Idem à foto $79 \mathrm{com}$ analisador inserido.

Foto 81: Fotomicrografia de bandas nematolepidoblásticas descontínuas, compostas por biotita, muscovita, sillimanita e clorita, definem a foliação principal S2 conjuntamente com bandas granoblásticas constituídas por quartzo e plagioclásio. Foliação S2 apresenta-se anastomosada. Unidade Tambillito, Amostra UM651A. Foto com nicóis paralelos e lado maior igual a $5,1 \mathrm{~mm}$.

Foto 82: Idem à foto $81 \mathrm{com}$ analisador inserido.

Foto 83: Fotomicrografia de estrutura bandada de rocha calciossilicática com predomínio de bandas nematoblásticas formada por hornblenda, epidoto/clinozoisita e titanita, e bandas descontínuas granoblásticas compostas por quartzo e carbonato. Unidade Tambillo, Amostra UM665A. Foto com nicóis paralelos e lado maior igual a 3,2mm.

Foto 84: Idem à foto 83 com analisadro inserido. 


\section{DISCUSSÃO}

Desde os trabalhos pioneiros de Hausen (1921), De Alba (1954), Turner (1964) e Furque (1972) a complexidade geológica das serras de Umango, Maz e Espinal foi exposta para a comunidade científica. Os autores já consideravam que diversas fases orogênicas teriam afetado as rochas da região, nomeando-as, por exemplo, de movimentos tectônicos do Precambriano, do Ciclo Caledoniano, do Ciclo Variscano Armoricano e do Ciclo Andino (Turner, 1964).

As Sierras Pampeanas Ocidentais possuem embasamento de idade mesoproterozóica (Varela \& Dalla Salda, 1992; Casquet et al., 2001, 2006, 2008; Varela et al., 1996, 2003a, 2003b; Porcher et al., 2004; Vujovich et al., 2004 e outros) e sequências metassedimentares neoproterozóicas (Galindo et al., 2004; Rapela et al., 2005 e Varela et al., 2001) que experimentaram juntos a Orogênese Famatiniana no Ordoviciano (Fase Ocloyica) (Casquet et al., 2001; Varela et al., 2003b, 2008) e no Devoniano (Fase Chanica) (Varela et al., 2002; Ramos et al., 1998).

A Sierra de Umango é considerada a porção norte do embasamento do Terreno exótico Cuyania (Sato et al., 2000; Varela et al., 2003a, 2003b; Sato et al., 2004; Porcher et al., 2004; Vujovich et al., 2004) ou Occidentalia (Dalla Salda et al., 1992a; Varela et al., 1996, 2000).

Idades mesoproterozóicas, variando de $1216 \pm 29$ (U/Pb em zircão) até $1030 \pm$ 30 ( $\mathrm{Rb} / \mathrm{Sr}$ rocha total), foram obtidas para os Ortognaisses Juchi (Varela et al., 1996, 2003a, 2003b, 2008), com idades modelo $T_{d m}(\mathrm{Sm} / \mathrm{Nd})$ de 1447 a $1485 \mathrm{Ma}$ com eNd(t) 2,3 a 2,7 (Varela et al., 2003a), $1250 \mathrm{Ma}$ com eNd(t) 4,2 e $1340 \mathrm{Ma}$ com eNd(t) 1,4 (Porcher et al., 2004). A idade Rb/Sr (rocha total) de aproximadamente $1000 \mathrm{Ma}$ foi interpretada como idade de metamorfismo (Varela et al., 2008). Metamorfismo de fácies granulito de idade mesoproterozóica (cerca de $1200 \mathrm{Ma}$ ) foi descrito no Grupo Maz, da serra homônima (Casquet et al., 2006). Porém, petrograficamente as rochas gnáissicas da Sierra de Umango (Ortognaisses Juchi) não apresentam evidências de polimetamorfismo. Novo dado U/Pb SHRIMP em bordas de grão de zircão com núcleo mesoproterozóico identificou idades próximas a $474 \mathrm{Ma}$, definindo para essas rochas idade de metamorfismo associado ao evento colisional Famatiniano (Varela et al., in press).

Varela et al. (2008) interpretou a idade U/Pb em zircão de $1108 \pm 4 \mathrm{Ma}$, obtida em anfibolito da Unidade Tambillito, como idade de cristalização de rochas básicas intrusivas na unidade clástica mesoproterozóica Tambillito. Porém, os autores não descartaram a possibilidade de que os grãos de zircão datados sejam xenocristais coletados das rochas hospedeiras. 
Estudos de isótopos de $\mathrm{Sr}, \mathrm{C}$ e $\mathrm{O}$ nos mármores da Unidade Tambillo demonstraram idade de sedimentação entre 580 e 640 Ma para esses carbonatos (Neoproterozóico) (Varela et al. 2001). Contudo, essa estimativa considerou que o metamorfismo (fácies anfibolito superior) desses carbonatos tenha ocorrido em sistemas fechados, e que as composições isotópicas originais sedimentares tenham sido preservadas durante todo o processo.

O detalhamento geológico, estratigráfico, geoquímico e estudos de proveniência são necessários para melhor entender a história sedimentar dessas unidades metassedimentares.

As fases deformacionais D1, D2 e D3, descritas nesse trabalho, foram relacionadas ao evento colisional Famatiniano que envolveu o bloco autóctone do sudoeste do Gondwana (Arco Magmático Famatina e Sierras Pampeanas Orientais), a leste e o Terreno alóctone Cuyania (Precordilheira e Sierras Pampeanas Ocidentais), a oeste. São interpretadas como fases de um único evento metamórfico, com D1 possivelmente registrando o metamorfismo progressivo, D2 condições P-T próximas ao pico metamórfico com duplicação da crosta, e D3 associada à regressão metamórfica com exumação parcial. A fase deformacional D2, responsável pela formação da foliação principal S2, foi datada nos Ortognaisses Juchi e Unidade Tambillo entre $447 \pm 36$ e $480 \pm 15$ Ma (Ordoviciano Inferior a Médio), utilizando os métodos $\mathrm{U} / \mathrm{Pb}$ em zircão, $\mathrm{U} / \mathrm{Pb}$ em monazita e $\mathrm{Rb} / \mathrm{Sr}$ rocha total (Varela et al., 2003a, 2003b, 2008).

As condições metamórficas para a fase D2 admitem regimes de média a alta $P$ e alta $T$ (pico metamórfico em fácies granulito de alta $P$ para os Ortognaisses Juchi e para as rochas da ZCCP) (Porcher et al., 2004; González et al., 2005 e Campos Neto et al., in prep.), condizentes com ambientes colisionais e de subducção de crosta continental. A exumação parcial dessa porção de crosta continental subductada foi ocorrida em um sistema de nappes e zonas de cisalhamento até condições, na fase D3, de fácies anfibolito inferior a xisto verde (Campos Neto et al., in prep.).

A cinemática desse sistema de nappes foi caracterizada por movimentos de topo para S-SW e zonas de cisalhamento dextrais (ZCCP) que empilharam as unidades geológicas descritas. Esse quadro estrutural estaria relacionado à colisão oblíqua do Terreno Cuyania, subductado sob a protomargem de Gondwana. O sentido de subducção para NE foi inferido com base na cinemática de extrusão sinmetamórfica, registrada nas nappes (topo para S-SW) e na ZCCP.

Fernandes et al. (2001), Fernandes et al. (2002) e Porcher et al. (2004) descrevem indicadores cinemáticos dúbios, sugerindo movimentações de topo para $\mathrm{N}$ e $\mathrm{S}$, porém caracterizaram movimento de topo para $\mathrm{N}$, diferentemente do que foi 
apresentado nesse trabalho, como o mais representativo para a zona de cisalhamento na região do Cerro Cacho (denominado aqui de ZCCP).

Entretanto, Le Corre \& Rosselo (1994) e Simpson et al. (2003) descreveram cinemática compatível com colisão ortogonal (E-W) nas Sierras Pampenas Orientais, relacionada à colisão Famatiniana.

Le Corre \& Rosselo (1994) reconheceram padrões estruturais e indicadores cinemáticos da história pré-carbonífera nas regiões de Puna e Sierras Pampeanas que indicam compressão E-W, com movimentação de topo para oeste nas Sierras Pampeanas. Essa cinemática, sin-metamórfica, não foi observada na Sierra de Umango.

Zonas de cisalhamento caracterizadas pela presença de milonitos e ultramilonitos em condições metamórficas de fácies xisto verde foram descritas por Simpson et al. (2003) nas Sierras de Córdoba e proximidades. As zonas de cisalhamento possuem mergulho geral para leste, com transporte em falhas de empurrão de leste para oeste, sendo que evidências locais de movimentos transcorrentes dextrais também ocorrem (Simpson et al., 2003). Os autores associam as faixas miloníticas e ultramiloníticas à acresção de terrenos na borda oeste de Gondwana, durante a orogênese Famatiniana.

Lucassen \& Becchio (2003) obtiveram idades U/Pb mais jovens, próximas a $430 \mathrm{Ma}$ (Siluriano), em titanita de rochas calciossilicáticas da Unidade Tambillo e interpretaram como a idade de metamorfismo de alta $\mathrm{T}$, ao qual essas rochas foram submetidas. Os autores consideram que as Sierras Pampeanas Ocidentais e a região de Puna Sul façam parte de uma extensa faixa móvel ("Early Paleozoic Mobile Belf") ativa entre o Cambriano e o Siluriano.

Os dados radiométricos para o Granito El Peñon, interpretado como sincolisional, corroboram com o metamorfismo no Ordoviciano Médio (Varela et al. 1996, 2008).

A idade de intrusão das rochas básicas associadas à Unidade El Cordobés segue incerta. Dados $\mathrm{Sm} / \mathrm{Nd}$ (rocha total, plagioclásio e anfibólio) de anfibolitos da região do Barreal Grande mostraram idade devoniana (392 $\pm 50 \mathrm{Ma}$ ) para o metamorfismo dessas rochas (Varela et al., 2002). Todavia, dados recentes U/Pb em zircão demonstraram idades mais antigas (446 $\pm 3 \mathrm{Ma}$ ), concordantes com as idades mais jovens para o evento colisional (Varela et al., 2008).

Varela et al. (2002) e Varela et al. (2008) consideram a Unidade El Cordobés e pegmatóides milonitizados, datados próximo à $370 \mathrm{Ma}(\mathrm{Sm} / \mathrm{Nd}$ rocha total e minerais Varela et al., 2002), vinculados à Tectônica Chanica. 
A fase deformacional (D4) pode estar associada à reativação tectônica ocorrida após a intrusão do Granito Los Guandacolinos e antes da deposição das rochas sedimentares da Formação Panacán (Grupo Paganzo). A fase D4 é interpretada como responsável pela deformação do Granito Los Guandacolinos, caracterizada por zonas de cisalhamento discretas que geraram uma foliação em estado sólido com orientações paralelas aos planos axiais das dobras D4. As dobras N-S e NE-SW que deformaram a Formação Punilla, observáveis nas imagens de satélite, e toda a seqüência metamórfica de Umango, também são associadas à fase D4. A discordância angular entre a Formação Punilla e a Formação Panacán (Grupo Paganzo), no extremo noroeste da Sierra de Las Minitas (ver Figura 8), é considerado uma evidência geológica para a idade máxima (Carbonífero Inferior) dessa deformação. A deformação associada à fase D4 aparentemente ocorreu em níveis crustais rasos com cinemática sinistral transpressiva.

Os dados geocronológicos obtidos para o Granito Los Guandacolinos apresentam consideráveis dúvidas. Os primeiros dados radiométricos $(\mathrm{Rb} / \mathrm{Sr}$ rocha total) indicaram isócrona de idade devoniana superior-carbonífera inferior (352 \pm 14 Ma) (Varela et al., 1996). Novos estudos $\mathrm{Rb} / \mathrm{Sr}$ (rocha total) e estudos U/Pb em zircão obtiveram idades mais recentes (errócrona $\mathrm{Rb} / \mathrm{Sr} 324 \pm 36 \mathrm{Ma}$ e U/Pb em zircão $314 \pm$ $14 \mathrm{Ma}$ ), posicionando a intrusão do Granito Los Guandacolinos no Carbonífero Superior (Varela et al., 2005). Novos dados U/Pb SHRIMP em zircão, não publicados, apresentaram idades de núcleo do grão no Siluriano e borda devoniana para o Granito Los Guandacolinos (Basei, comunicação oral).

Varela et al. (2005) discutem a possibilidade da existência de movimentos tectônicos intracarboníferos, na passagem do Carbonífero Inferior para o Carbonífero Superior, denominada de Fase Rio Blanco (Fauqué et al., 1999). Contudo, Azcuy et al. (1999) consideram a passagem supracitada como transicional e associam a deformação da Formação Punilla à Tectônica Chanica, no Devoniano Superior.

Com base nos dados geocronológicos, Varela et al. (2005) interpretaram a idade de deformação do Granito Los Guandacolinos entre $314 \pm 14$ (idade de intrusão e cristalização do Granito Los Guandacolinos) e $311 \pm 15$ Ma (idade de cristalização do Granito Cerro Veladero) (Cingolani et al., 1999), associando-a à Fase Rio Blanco. A interpretação de Varela et al. (2005) leva em conta a ausência de deformação no Granito Cerro Veladero, descrito e datado por Cingolani et al. (1999).

Neste trabalho, consideramos a idade do Siluriano para a cristalização do "stock" granítico Los Guandacolinos e admitimos a idade do Devoniano Superior para a fase de dobramentos D4, associada à Tectônica Chanica, em concordância com a proposta de Azcuy et al. (1999) e Varela et al. (2002). 
Estágios deformacionais caracterizados por transpressão sinistral foram descritos na Sierra de San Luis e considerados de idade devoniana (Von Gosen, 1998).

O soerguimento das rochas do embasamento aflorantes nas Sierras Pampeanas ocorreu durante o Ciclo Tectônico Andino, no Cenozóico Superior e possivelmente reativou diversas estruturas pré-existentes (Ramos et al., 2002). A fase deformacional D5 pode estar relacionada à Tectônica Andina. Comparando a Figura 5 (Ramos et al., 2002) com o esquema tectônico da Figura 4 (Quernadelle \& Ramos, 1999) observa-se uma intensa modificação geométrica nas estruturas ordovicianas, com a rotação anti-horária do bloco Cuyania e Famatina.

\section{CONSIDERAÇÕES FINAIS}

As rochas metamórficas expostas na Sierra de Umango estão dispostas em um sistema de nappes e zonas de cisalhamento associado à colisão entre o Terreno Cuyania e o Arco Magmático Famatina, no Ordoviciano.

A ausência de evidências petrográficas e estruturais para a existência de evento metamórfico anterior ao Ordoviciano, principalmente na Unidade mesoproterozóica Ortognaisses Juchi, leva à interpretação de que as rochas ígneas e metassedimentares da Sierra de Umango (unidades Juchi, Tambillo, Tambillito, El Peñon e El Cordobés) sofreram metamorfismo apenas no Ordoviciano, seguido de processos deformacionais posteriores.

Pelo menos cinco fases deformacionais afetaram as rochas gnáissicas e metassedimentares da Sierra de Umango. As três primeiras fases (D1, D2 e D3) foram interpretadas como pertencentes à colisão ordoviciana entre o Terreno Cuyania e a protomargem Andina de Gondwana. A colisão, aparentemente de baixo ângulo, foi lateral à protomargem Andina. As condições de pressão e temperatura no pico metamórfico alcançaram fácies anfibolito superior a granulito em regimes de média a alta pressão.

O padrão cilíndrico do dobramento D4 com eixo subhorizontal pressupõe uma disposição horizontal ou subhorizontal para as superfícies S2 e S3. A fase de deformação D4 foi associada à nova ativação tectônica compressiva no Devoniano Superior (ou na transição do Carbonífero Inferior para Superior?), caracterizada por dobras flexurais normais, cilíndricas, predominantemente abertas, e zonas de cisalhamento discretas sinistrais com componente inverso, que dobraram e deformaram toda a seqüência ígneo-metamórfica de Umango. Tal deformação ocorreu em níveis crustais mais rasos sob, provavelmente, metamorfismo de baixo grau. 
Dobras posteriores (D5), de eixo com orientação E-W, foram reconhecidas no campo, nos estereogramas e no desenho geral da Sierra de Umango, e possivelmente são vinculadas à tectônica de soerguimento no Ciclo Andino.

O embasamento da Sierra de Umango (Ortognaisses Juchi) repousa em estruturas do tipo klippen sobre as rochas da Unidade Tambillo (Klippe Água La Falda e Klippe Juchi), preservadas em dobras sinformais normais (D4) de caimento axial principal para sul.

As unidades metassedimentares reconhecidas na Sierra de Umango (unidades Tambillo e Tambillito) necessitam de maior detalhamento estratigráfico-estrutural, assim como estudos de proveniência, para o melhor entendimento do ambiente e história deposicional dessas rochas. O estudo geoquímico sistemático nas rochas metabásicas da Sierra de Umango (anfibolitos da Unidade Tambillo, metagabro com granada na ZCCP, metabásicas e metagabros da Unidade El Cordobés, e metagabro do contato entre Unidade Tambillo e Tambillito) facilitará a interpretação geodinâmica da colocação dos magmas básicos durante a história geológica dessa região das Sierras Pampeanas Ocidentais.

A Unidade Tambillo representa cerca de 60\% em área da Sierra de Umango e compreende uma seqüência metavulcanossedimentar, com intercalações de anfibolitos, mármores, rochas calciossilicáticas, metagrauvacas, metasemi-pelitos e metapsamitos.

A Unidade Tambillito está delineada por sinforma normal (D4) com flanco ocidental invertido (região do Rio Umango e Puesto Tambillito) e caimento axial de baixo ângulo para norte. É caracterizada por sequência metassedimentar siliciclástica, pelito-psamítica, com anfibólio xistos e anfibolitos subordinados.

Os granitóides aflorantes na Sierra de Umango foram interpretados da seguinte forma: Granito El Peñon - sin-colisional, introduzido na porção sudeste da Unidade Tambillo durante a fase deformacional D2; Granito Los Guandacolinos - granito póscolisional e pré-fase deformacional D4; e Granito Cerro Veladero - pós-colisional e pós-fase deformacional D4. Essas relações situam a fase D4 há cerca de $350 \mathrm{Ma}$, na interface Devoniano-Carbonífero, compatível com a discordância angular mapeada no extremo noroeste da Sierra de Las Minitas.

A caracterização cinemática das rochas de Umango define transporte das klippen Juchi e Água La falda, e da Unidade Tambillo para S-SW.

A configuração geodinâmica apresentada sugere um cenário, no Ordoviciano, de subducção continental (unidades Juchi e Tambillo) sob elevado fluxo térmico (fácies granulito), e conseqüente exumação em sistema de nappes (Fase Tectônica Ocloyica). O sentido de subducção foi para NE sob a protomargem ativa de 
Gondwana, indicado pela cinemática de extrusão sin-metamórfica (transporte de topo para S-SW).

O metamorfismo de alta pressão registra a participação da crosta continental do Terreno Cuyania na colisão oblíqua com o Arco Magmático de Famatina. A exumação parcial de fatias da crosta continental subductada foi facilitada por zonas profundas de cisalhamento dextral (ZCCP), provavelmente gerada na obliqüidade da convergência.

A intrusão do "stock" granítico Los Guandacolinos ocorreu no Siluriano, provavelmente associado à migração da zona de subducção para W.

Reativação tectônica compressiva no Devoniano causou uma deformação caracterizada por dobras abertas e zonas de cisalhamento sinistrais discretas, que afetaram as rochas previamente deformadas de Umango, rochas sedimentares devonianas da Pré-Cordilheira (Formação Punilla) e o Granito Los Guandacolinos. Essa deformação pode estar relacionada com a Fase tectônica Chanica, frequentemente associada à colisão do Terreno Chilenia.

Novo magmatismo granítico no Carbonífero (Granito Cerro Veladero), vinculado ao Ciclo Tectônico Gondwânico, foi introduzido na porção sul do embasamento da Sierra de Umango.

Bacias sedimentares extensionais do Carbonífero Superior ao Permiano (Bacia Paganzo) e do Mesozóico (Bacia do Ischigualasto) marcam o colapso do Orógeno Famatiniano. As bacias terciárias são consideradas de retroarco para a tectônica Andina. Conjuntamente com os terraços quaternários, essas unidades repousam discordantemente sobre a sequência ígneo-metamórfica da Sierra de Umango.

\section{REFERÊNCIAS BIBLIOGRÁFICAS}

ACEÑOlANZA, F.G., TOSELLI, A., BERNASCONI, A., 1971. La Precordillera de Jague, La Rioja, Argentina: Su importancia geológica y estructural. Acta Geológica Lilloana 11(14) 260-290.

ACEÑOlANZA F.G., MILLER H., TOSELLI, A.J., 2002. Proterozoic-Early Paleozoic evolution in western South America: a discussion. Tectonophysics (354) 121-137.

ALLMENDINGER, R.W., FIGUEROA, D., SNYDER, D., BEER, J., MPODOZIS, C., ISACKS, B.L., 1990. Foreland shortening and crustal balancing in the Andes at $30^{\circ} \mathrm{S}$ latitude. Tectonics (9) 789-809.

ASTINI, R.A., BENEDETTO, J.L., VACCARI, N.E., 1995. The early Paleozoic evolution of the Argentine Precordillera as a Laurentian rifted, drifted and collided terrane: a geodynamic model. Geological Society of America Bulletin (107) 253-273. 
ASTINI, R.A. \& THOMAS W.A., 1999. Origin and evolution of Precordillera Terrane, western Argentina: A drifted Laurentian orphan. Geological Society of America, Special Paper (336) 1-20.

AZCUY, C.L., CARRIZO, H.A., CAMINOS, R., 1999. Carbonífero y Pérmico da las Sierras Pampeanas, Famatina, Precordillera, Cordillera Frontal y Bloque de San Rafael. In: CAMINOS, R., (ed.). Geologia Argentina. Servicio Geológico Minero Argentino, Anais 29, 261-318.

BALDIS, B. A., BERESI, M. S., BORDONARO, O., VACA, A., 1984. The Argentine Precordillera as a key to the Andean structure. Episodes (17) 14-19.

BENEDETTO, J. L., 1993. La hipótesis de la aloctonía de la Precordillera Argentina: Un test estratigráfico y biogeográfico. Mendoza, XII Congreso Geológico Argentino (3) 375-384.

BENEDETTO, J.L., 2004. The allochthony of the Argentine Precordillera ten years later (1993-2003): a new paleobiogeographic test of the Microcontinent Model. Gondwana Research (7) 1027-1039.

CAMINOS, R., 1979. Sierras Pampeanas Noroccidentales. Salta, Tucumán, Catamarca, La Rioja y San Juan. I/ Simposio de Geología Regional Argentina (1) 225-291.

CAMINOS, R. \& FAUQUÉ, L., 1999. Hoja Geológica 2969-II Tinogasta, La Rioja y Catamarca. Instituto de Geologia y Recursos Minerales (Servicio Geológico Minero Argentino), Boletin $\mathrm{N}^{\circ} 276$.

CASQUET, C., BALDO, E., PANKHURST, R.J., RAPELA, C.W., GALINDO, C., FANNING, C.M., SAAVEDRA, J., 2001. Involvement of the Argentine Precordilhera terrane in the Famatinian Mobile Belt:U/Pb SHRIMP and metamorphic evidence from the Pie de Palo. Geology (29) 703-706.

CASQUET, C., PANKHURST, R.J., RAPELA, C.W., GALINDO, C., DAHLQUIST, J., BALDO, E., SAAVEDRA, J., GONZÁLEZ-CASADO, J.M., FANNING, C.M., 2004. Grenvillian massif-type anorthosites in the Sierras Pampeanas. Journal of the Geological Society of London (162) 9-12.

CASQUET, C., PANKHURST, R.J., FANNING, C.M., BALDO, E., GALINDO, C., RAPELA, C.W., GONZÁLEZ-CASADO, J.M., DAHLQUIST, J.A., 2006. U/Pb SHRIMP zircon dating of Grenvillian metamorphism in Western Sierras Pampeanas (Argentina): correlation with the Arequipa Antofalla craton and constraints on the extent of the Precordillera Terrane. Gondwana Research (9) 524-529.

CASQUET, C., PANKHURST, R.J., RAPELA, C., GALINDO, C., FANNING, C.M., CHIARADIA, M., BALDO, E., GONZÁLEZ-CASADO, J.M., DAHLQUIST, J.A., 
2008a. The Maz terrane: a Mesoproterozoic domain in the western Sierras Pampeanas (Argentina) equivalent to the Arequipa-Antofalla block of southern Perú? Implications for Western Gondwana margin evolution. Gondwana Research (13) 163-175.

CASQUET, C., PANKHURST, R.J., GALINDO, C., RAPELA, C., FANNING, C.M., BALDO, E., DAHLQUIST, J., GONZÁLEZ-CASADO, J.M., COLOMBO, F., 2008b. A deformed alkaline igneous rock-carbonatite complex from the Western Sierras Pampeanas, Argentina: Evidence for late Neoproterozoic opening of the Clymene Ocean? Precambrian Research (165) 205-220.

CHERNICOFF, C.J., ZAPPETTINI, E.O., SANTOS, J.O.S., BEYER, E., MCNAUGHTON, N.J., 2008. Foreland basin deposits associated with Cuyania accretion in La Pampa Province, Argentina. Gondwana Research (13) 189-203.

CINGOLANI, C., VARELA, R., DALLA SALDA, L., KAWASHITA, K., 1993. Los granitoides del cerro Veladero, río de la Troya, provincia de La Rioja: estudio geocronológico e implicancias tectónicas. XII Congreso Geológico Argentino e II Congreso de Exploración de Hidrocarburos (4) 68-74.

COIRA, B., DAVIDSON, J., MPODOZIS, C., RAMOS, V., 1982. Tectonic and magmatic evolution of the Andes of Northern Argentina and Chile. Earth-Science Reviews (18) 303-332.

CONEY, P.J., JONES, D.L., MONGER, J.W.H., 1980. Cordilleran suspects terranes. Nature (288) 303-333.

CONTI, C.M., RAPALINI, A.E., COIRA, B., KOUKHARSKY, M., 1996. Paleomagnetic evidence of an early Paleozoic rotated terrane in northwest Argentina: a clue of Gondwana-Laurentia interaction? Geology (24) 953-956.

DALLA SALDA, L., CINGOLANI, C., VARELA, R., 1992a. Early Paleozoic orogenic belt of the Andes in southwestern South America: Result of Laurentia-Gondwana collision? Geology (20) 617-620.

DALLA SALDA, L., DALZIEL, I.W.D, CINGOLANI, C., VARELA, R., 1992b. Did the Taconic Appalachians continue into southern South America? Geology (20) 1059-1062.

DALZIEL, I.W.D., 1991. Pacific margins of Laurentia and East Antarctica-Australia as a conjugate rift pair: Evidence and implications for an Eocambrian supercontinent. Geology (19) 598-601.

DALZIEL, I.W.D., DALLA SALDA, L.H., GAHAGAN, L.M., 1994. Paleozoic LaurentiaGondwana interaction and the origin of the Appalachian-Andean mountain system. Geological Society of America Bulletin (106) 243-252. 
DALZIEL, I.W.D., 1997. Overview: Neoproterozoic-Paleozoic geography and tectonics: Review, hypothesis, environmental speculation. Geological Society of America Bulletin (109) 16-42.

DE ALBA, E., 1954. Descripción geológica de la Hoja 16c, Villa Unión. Boletín de la Dirección Nacional de Geología y Minería (82) 1-81.

DEWEY, J.F. \& BIRD, J., 1970. Mountain belts and the new global tectonics. Geophysical Research (75) 1625-2647.

FAUQUÉ, L., LIMARINO, O., CINGOLANI, C., VARELA, R., 1999. Los movimientos intracarboníferos en la Precordillera riojana. XIV Congreso Geológico Argentino (1) 421-424.

FAUQUÉ, L., LIMARINO, C., VUJOVICH, G., FERNÁNDEZ, L., CEGARRA, M., ECOSTEGUY, L. 2004. Hoja Geológica 2969-IV Villa Unión, La Rioja y San Juan. Instituto de Geologia y Recursos Minerales (Servicio Geologico Minero Argentino), Boletin $\mathrm{N}^{\circ} 345$.

FERNANDES, L.A.D., PORCHER, C.C., VUJOVICH, G.I., ESCOSTEGUY, L.D., MORALES, L.F.G., 2001. Geologia estructural de los gneises de las Sierras de Maz Y Umango, La Rioja, Argentina: Datos preliminares. XI Congresso Latinoamericano de Geologia, Montevidéo.

FERNANDES, L.A.D., PORCHER, C.C., VUJOVICH, G.I., SILVA, A.M.O., ESCOSTEGUY, L.D., FAUQUÉ, L., MORALES, L.F.G., 2002. Geologia estructural e termobarometria dos gnaisses das Serras Pampeanas do NW e suas implicações na evolução tectônica da Precordilheira argentina. XV Congreso Geológico Argentino. Actas 2, 188-192.

FINNEY, S., GLEASON, J., GEHRELS, G., PERALTA, S., ACEÑOLANZA, G., 2003. Early Gondwanan connection for Argentina Precordillera terrane. Earth and Planetary Sciences Letters (205) 349-359.

FURQUE, G., 1972. Descripción Geológica de la Hoja 16b, Cerro La Bolsa, Provincia de La Rioja y San Juan. Servicio Nacional Minerio y Geológico, Boletín (125) 169. Buenos Aires.

GALINDO, C., CASQUET, C., RAPELA, C.W., PANKHURST, R.J., BALDO, E., SAAVEDRA, J., 2004. Sr, $C$ and 0 isotope geochemistry and stratigraphy of Precambrian and lower Paleozoic carbonate sequences from the Western Sierras Pampeanas of Argentina: tectonic implications. Precambrian Research (131) 55-71.

GANSSER, A., 1973. Facts and theories on the Andes. Journal of the Geological Society of London (129) 93-131. 
GONZÁLEZ, P.D., SATO, A.M., LLAMBIAS, E.J., BASEI, M.A.S., VLACH, S.R.F., 2004. Early Paleozoic structural and metamorphic evolution of western Sierra de San Luis, in relation to the accretion of Cuyania. Gondwana Research (7) 11571170.

GONZÁLEZ, P.D., VARELA, R., VLACH, S., 2005. Eclogite to HP-granulite facies metamorphism in mafic rocks at Sierra de Umango, Argentina: relics of subducted ophiolite complex in western Gondwana? In: PANKHURST, R.J. \& VEIGA, G.D. (eds.) Gondwana 12. Academia Nacional de Ciencias, Mendoza, Argentina, 178p.

HAUSEN, H., 1921. On the lithology and geological structure of the Sierra de Umango Area, Province of La Rioja, Argentine Republic. Acta Academiae Aboensis, Mathematica et Physica I:(4) 1-138.

HOWELL, D.G., 1989. Tectonics of suspect terranes. Mountain building and continental growth. Chapman \& Hall, 232p.

JONES, D.L., HOWELL, D.G., CONEY, P.J., MONGER, J.W.H., 1983. Recognition, character and analysis of tectonostratigraphic terranes in Western North America. In: HASHIMOTO, M. \& UYEDA, S. (eds.). Accrection tectonics in the CircumPacific regions. TERRAPUB, Tokyo, 21-35.

JORDAN, T.E., ISACKS, B.L., ALLMENDINGER, R.W., BREWER, J.A., RAMOS V.A., ANDO, C.J., 1983. Andean tectonics related to geometry of subducted Nazca plate. Geological Society of America Bulletin (94) 341-361.

JORDAN, T.E., ALLMENDINGER, R.W., DAMANTI, J.F., DRAKE, R.E., 1993. .Chronology of motion in a Complete Thrust Belt: The Precordillera, 30-31 ${ }^{\circ} \mathrm{S}$, Andean Mountains. The Journal of Geology (101) 135-156.

KELLER, M., BUGGISH, W., LEHNERT, O., 1998. The stratigraphic record of the Argentine Precordillera and its plate tectonic background. In: PANKHURST, R.J. \& RAPELA, C.W. (eds.). The Proto-Andean margin of Gondwana. Special Publication of the Geological Society of London (142) 35-56.

KELLER, M. 1999. Argentine Precordillera: sedimentary and plate tectonic history of a Laurentian crustal fragment in South America. Geological Society of America Special Paper (341) 131p.

KILMURRAY, J.O., IÑIGUEZ RODRIGUEZ, M., 1968. Los gneises escapolíticos de Las Ramaditas, Villa Unión (Provincia de La Rioja). Revista del Museo de La Plata (7) 13-29.

KILMURRAY, J.O., 1969. Petrología de las rocas metamórficas del sector noreste de la sierra de Maz, Villa Unión, Provincia de La Rioja. IV Jornadas Geológicas Argentinas (1) 409-428. 
KILMURRAY, J.O., 1970. Las facies de metamorfismo en la Sierra de Maz, Provincia de La Rioja, República Argentina. Revista de la Asociacón Argentina de Mineralogía, Petrología y Sedimentología (1) 57-70.

KILMURRAY, J.O., 1971. Las ortoanfibolitas de la Sierra de Maz, Provincia de La Rioja. Revista del Museo de La Plata (7) 51-146.

KILMURRAY, J.O., \& DALLA SALDA, L., 1971. Las fases de deformación y metamorfismo en la sierra de Maz, provincia de La Rioja, República Argentina. Revista de la Asociación Geológica Argentina (26) 245-263.

LE CORRE C.A. \& ROSSELLO E.A., 1994. Kinematics of early paleozoic ductile deformation in the basement of NW Argentina. Journal of South American Herat Sciences (7) 301-308.

LIMARINO, C.O.. CÉSARI, S.N., NET, L. I., MARENSSI S.A.. GUTIERREZ, R.P., TRIPALDIA, A., 2002. The Upper Carboniferous postglacial transgression in the Paganzo and Rio Blanco basins (northwerstn Argentina): facies and stratigraphic significance. Journal of South American Earth Sciences (15) 445-460.

LUCASSEN, F., BECCHIO, R., 2003. Timing of high-grade metamorphism: early Palaeozoic $\mathrm{U} / \mathrm{Pb}$ formation ages of titanite indicate long-standing high- $\mathrm{T}$ conditions at the western margin of Gondwana (Argentina, 26-29ㅇ). Journal of Metamorphic Geology (21) 649-662.

MARTINA, F., ASTINI, R.A., 2009. Geología de la región del Río Bonete en el antepaís

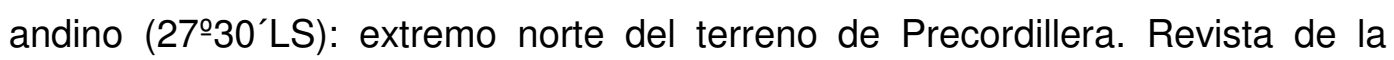
Asociacion Geológica Argentina (64) 312-328.

PASSCHIER \& TROUW, R.A.J., 1996. Microtectonics. Springer, Berlin, 282p.

PANKHURST, R.J. \& RAPELA, C.W., 1998. The proto-Andean margin of Gondwana: an introduction. In: PANKHURST, R.J. \& RAPELA, C.W., (eds.). The ProtoAndean margin of Gondwana. Special Publication of the Geological Society of London (142) 1-9.

PANKHURST, R. J., RAPELA, C.W., FANNING, C.M., 2000. Age and origin of coeval TTG, I-S type granites in the Famatinian belt of NW Argentine. Transactions of the Royal Society of Edinburgh, Earth Sciences (91) 151-168.

PORCHER, C.C., FERNANDES, L.A.D., VUJOVICH, G.I., CHERNICOFF, C.J., 2004. Thermobarometry, Sm/Nd ages and geophysical evidence for location of the suture zone between Cuyania and the Western Proto-Andean Margin of Gondwana. Gondwana Research (7) 1057-1076.

QUERNADELLE, S. \& RAMOS, V.A., 1999. The Ordovician western Sierras Pampeanas magmatic belt: record of Precordillera accretion in Argentina. In: 
RAMOS, V.A. and KEPPIE, J.D. (eds.). Laurentia Gondwana connections before Pangea. Geological Society of America, Special Paper (336) 63-86.

RAMOS, V.A., JORDAN, T., ALLMENDINGER, R.W., KAY, S.M., CORTÉS, J.M., PALMA, M.A., 1984. Chilenia: Un terreno alóctono en la evolución paleozoica de los Andes Centrales. IX Congreso Geológico Argentino. Actas 2, 84-106.

RAMOS, V.A., JORDAN, T.E., ALLMENDINGER, R.W., MPODOZIS, C., KAY, S.M., CORTÉS, J.M., PALMA, M.A., 1986. Paleozoic terranes of the central ArgentineChilean Andes. Tectonics (5) 855-880.

RAMOS, V.A., 1988a. Tectonics of the Late Proterozoic - Early Paleozoic: a collisional history of southern South America. Episodes (11) 168-174.

RAMOS, V.A., 1988b. The Tectonics of the Central Andes: $30^{\circ}-33^{\circ} \mathrm{S}$ latitude. In: CLARK, S., BURCHFIEL, D., SUPPE, J., (eds.). Processes in continental lithospheric deformation. Geological Society of America, Special Paper (218) 3154.

RAMOS, V.A., 1995. Sudamérica: un mosaico de continentes y océanos. Ciencia Hoy (6) 24-29.

RAMOS, V.A., VUJOVICH, G.I., DALLMEYER, R.D., 1996. Los klippes y ventanas tectónicas preándicas de la Sierra de Pie de Palo (San Juan): edad e implicaciones tectonicas. XIII Congreso Geológico Argentino and III Congreso de Exploración de Hidrocarburos. Actas 5, 377-391.

RAMOS, V.A., DALLMEYER, R.D., VUJOVICH, G.I., 1998. Time constraints on the Early Paleozoic docking of the Precordillera, central Argentina. In: PANKHURST, R.J. \& RAPELA, C.W., (eds.). The Proto-Andean margin of Gondwana. Special Publication of the Geological Society of London (142) 143-158.

RAMOS, V.A., 1999a. Plate tectonic setting of the Andean Cordillera. Episodes (22) 183-189.

RAMOS, V.A., 1999b. Rasgos estructurales del territorio Argentino. In: CAMINOS, R., (ed.). Geologia Argentina. Servicio Geológico Minero Argentino, Anais 29, 715784.

RAMOS, V.A., ESCAYOLA, M., MUTTI, D., VUJOVICH, G.I., 2000. Proterozoic-early Paleozoic ophiolites in the Andean basement of southern South America. In: DILEK, Y., MOORES, E.M., ELTOHN, D., NICOLAS, A, (eds.). Ophiolites and oceanic crust: new insights from field studies and ocean drilling program. Geological Society of America, Special Paper (349) 331-349.

RAMOS, V.A., CRISTALLINI, E.O., PÉREZ, D.J., 2002. The Pampean flat-slab of the Central Andes. Journal of South American Earth Sciences (15) 59-78. 
RAMOS, V.A., 2004. Cuyania, an exotic block to Gondwana: Review of a historical success and the present problems. Gondwana Research (7) 1009-1026.

RAMOS, V.A., 2008. The basement of the Central Andes: the Arequipa and related terranes. Annual review of Earth and planetary sciences (36) 1-43.

RAMSAY, J.G. \& HUBER, M.I., 1983 e 1987. The Techniques of Modern Strucutral Geology, Vols. 1 e 2. Academic Press, Oxford.

RAPELA, C.W., PANKHURST, R.J., CASQUET, C., FANNING, C.M., GALINDO, C., BALDO, E., 2005. Datación U-Pb SHRIMP de circones detríticos en paraanfibolitas neoproterozoicas de la secuencia Difunta Correa (Sierras Pampeanas Occidentales, Argentina). Geogaceta (38) 227-230.

RAPELA, C.W., PANKHURST, R.J., CASQUET, C., BALDO, E., SAAVEDRA, J., GALINDO, C. AND FANNING, C.M., 1998. The Pampean Orogeny of the southern proto-Andes: Cambrian continental collision in the Sierras de Córdoba. In: PANKHURST, R.J. \& RAPELA, C.W. (eds.). The Proto-Andean margin of Gondwana. Special Publication of the Geological Society of London (142) 181217.

RAPELA, C.W., PANKHURST, R.J., CASQUET, C., BALDO, E., GALINDO, C., FANNING, C.M., DAHLQUIST, J.M., 2010. The Western Sierras Pampeanas: Protracted Grenville-age history (1330-1030 Ma) of intra-oceanic arcs, subduction-accretion at continental edge and AMCG intraplate magmatism. Journal of South American Earth Sciences (29) 105-127.

SATO, A.M., TICKYJ, H., LLAMBÍAS, E.J., SATO, K., 2000. The Las Matras tonalitictrondhjemitic pluton, central Argentina: Grenvillian-age constraints, geochemical characteristics, and regional implications. Journal of South American Earth Sciences (13) 587-610.

SATO, A.M., TICKYJ ,H., LLAMBIAS, E.J., BASEI, M.A.S.,GONZALEZ, P.D., 2004. Las Matras Block, Central Argentina $\left(37^{\circ} \mathrm{S}-67^{\circ} \mathrm{W}\right)$ : The southernmost Cuyania terrane and its relationship with the Famatinian Orogeny. Gondwana Research (7) 1077-1087.

SIMPSON, C., LAW, R.D., GROMET, L.P., MIRO, R., NORTHRUP, C.J., 2003. Paleozoic deformation in the Sierras de Córdoba and Sierra de Las Minas, eastern Sierras Pampeanas, Argentina. Journal of South American Earth Sciences (13) 749-764.

SPEAR, F.S., 1993. Metamorphic Phase Equilibria and Pressure-Temperature-Time Paths. Mineralogical Society of America, 798p.

THOMAS, W.A. \& ASTINI, R.A., 1996. The Argentine Precordillera: a traveler from the Ouachita embayment of North American Laurentia. Science (273) 752-757. 
THOMAS, W.A. \& ASTINI, R.A., 2003. Ordovician accretion of the Argentine Precordillera terrane to Gondwana: a review. Journal of South American Earth Sciences (16) 67-79.

THOMAS, W.A. \& ASTINI, R.A., 2007. Vestiges of na Ordovician West-vergent thinskinned Ocloyic thrust belt in the Argentine Precordillera, southern Central Andes. Journal of Structural Geology (29) 1369-1385.

TOSELLI, A.J., DURAND, ER., ROSSI DE TOSELLI, J.N., SAAVEDRA, J., 1996. Esquema de evolución geotectónica y magmatica eopaleozoica del Sistema de Famatina y sectores de Sierras Pampeanas. XIII Congreso Geológico Argentino and III Congreso de Exploración de Hidrocarburos. Actas, 5, 443-462.

TURNER, J.C.M., 1964. Descripción geológica de la Hoja 15c, Vinchina. Boletín de la Dirección Nacional de Geología y Minería (100) 1-86.

VARELA, R. \& DALLA SALDA, L., 1992. Geocronologia Rb-Sr de metamorfitas y granitóides del extremo sur de la Sierra de Pie de Palo, San Juan. Revista de La Asociacíon Geológica Argentina (47) 271-275.

VARELA, R., LÓPEZ DE LUCHI, M., CINGOLANI, C., DALLA SALDA, L. 1996. Geocronología de gneises y granitoides de la Sierra de Umango, La Rioja. Implicancias tectónicas. XIII Congreso Geológico Argentino y III Congreso de Exploración de Hidrocarburos. Actas 3, 519-527.

VARELA, R., ROVERANO, D., SATO, A.M., 2000. Granito El Peñón, sierra de Umango: descripción, edad Rb/Sr e implicancias geotectónicas. Revista de la Asociación Geológica Argentina (55) 407-413.

VARELA, R., VALENCIO, S.A., RAMOS, A.M., SATO, K., GONZÁLEZ, P.D., PANARELLO, H.O., ROVERANO, D.R., 2001. Isotopic Strontium, Carbon and Oxygen study on Neoproterozoic marbles from sierra de Umango, Andean Foreland, Argentina. III South American Symposium on Isotope Geology, Revista Comunicaciones (52: 121, CD Sociedad Geologica Chilena) 450-453.

VARELA, R., SATO, A.M., GONZÁLEZ, P.D., 2002. Metamorfismo y deformación Devónicos en la Sierra de Umango, Sierras Pampeanas Occidentales, La Rioja, Argentina. XV Congreso Geológico Argentino. Actas 2, 57-63.

VARELA, R., SATO, A.M., BASEI, M.A.S., SIGA JR, O., 2003a. Proterozoico medio y Paleozoico inferior de la Sierra de Umango, Antepaís Andino (29옥), Argentina. Edades $\mathrm{U} / \mathrm{Pb}$ y caracterizaciones isotópicas. Revista Geologica do Chile (30) 265-284.

VARELA, R., BASEI, M.A.S., SATO, A.M., GONZÁLEZ, P.D., SIGA JR., O., CAMPOS NETO, M.C., CINGOLANI, C.A., 2003b. Grevillian basement and famatinian 
events of the Sierra de Umango $\left(29^{\circ} \mathrm{S}\right)$ : a review and new geochronogical data. IV South American Symposium on Isotope Geology, Short Papers.

VARELA, R., BASEI, M.A.S., SATO, A.M., PASSARELLI, C.R., CINGOLANI, C.A., GONZÁLEZ, P.D., 2005. Edades U/Pb y Rb-Sr del Granito Los Guandacolinos, sierra de Umango, La Rioja. Implicancias tectónicas. XVI Congreso Geológico Argentino. Actas 1, 109-116.

VARELA, R., BASEI, M.A.S., SATO, A.M., GONZÁLEZ, P.D., SIGA JR., O., CAMPOS NETO, M.C., CINGOLANI, C.A. 2008. New O-Pb data for Sierra de Umango, Andean Foreland at $29^{\circ} \mathrm{S}$ and geodadynamic implications. VI South American Symposium on Isotope Geology. Short Papers.

VARELA, R., BASEI, M. A. S., GONZÁlEZ, P. D., SATO, A. M., NAIPAUER, M., CAMPOS NETO, M. C., CINGOLANI, C. A., MEIRA, V. T., (in press). Accretion of Grenvillian terranes to the west of the Rio de la Plata craton, western Argentina. International Journal of Earth Sciences.

VERNON, R.H., 2004. A practical guide to Rock Microstructure. Cambrige University Press, Cambridge, 594p.

VERNON, R.H. \& CLARKE, G.L., 2008. Principles of Metamorphic Petrology. Cambridge University Press, Cambrige, 446p.

VON GOSEN, W., 1992. Structural evolution of the Argentine Precordillera: the Rio San Juan section. Journal of Structural Geology (14) 643-667.

VON GOSEN, W., BUGGISCH, W., LEHNERT, O., 1995. Evolution of the southwestern Argentine Precordillera. Journal of South American Sciences (8) 377-404.

VON GOSEN, W., 1997. Early Paleozoic and Andean structural evolution in the Rio Jáchal section of the Argentine Precordillera. Journal of South American Earth Sciences (10) 361-388.

VUJOVICH, G.I., 1994. Reinterpretación geoquímica de las anfibolitas del Cerra Valdívia, Provincia de San Juan. II Jornada de Mineralógica, Petrológica y Metalogenésis de Rocas Ultrabásicas, IRM, UNLP (3) 653-662.

VUJOVICH, G.I. \& Kay, S.M., 1998. A Laurentian? Grenville-age oceanic arc/back-arc terrane in the Sierra de Pie de Palo, Western Sierras Pampeanas, Argentina. In: PANKHURST, R.J. \& RAPELA, C.W., (eds.). The Proto-Andean margin of Gondwana. Special Publication of the Geological Society of London (142) 159180.

VUJOVICH, G.I., FERDANDES, L.A.D., PORCHER, C.C., FAUQUÉ, L., 2001. Sierras Pampeanas Noroccidentales, La Rioja, Argentina: su integración regional. XI 
Congreso Latinoamericano de Geología y III Congreso Uruguayo de Geología 133.

VUJOVICH, G.I., VAN STAAL, C.R., DAVIS, W., 2004. Age constraints on the tectonic evolution and provenance of the Pie de Palo Complex, Cuyania composite terrane, and the Famatinian orogeny in the Sierra de Pie de Palo, San Juan, Argentina. Gondwana Research (7) 1041-1056. 


\section{ANEXOS}

Anexo 1: Mapas Geológicos, escalas 1:500.000 e 1:250.000.

Anexo 2: Mapas Geológicos e Seções Geológicas, escala 1:100.000.

Anexo 3: Tabela de pontos 

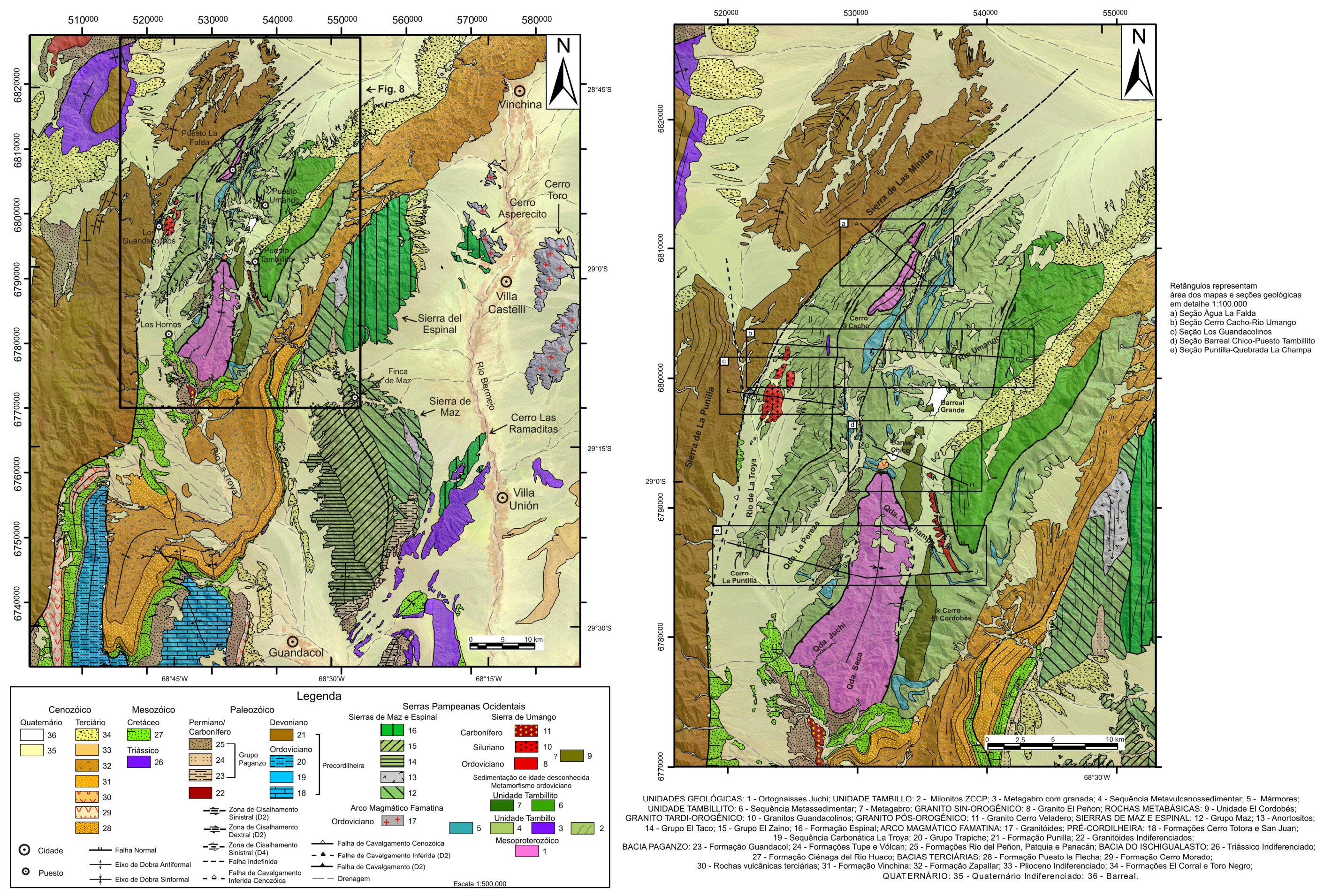

Anexo 1 - Evolução estrutural da Sierra de Umango, Sierras Pampeanas Ocidentais, Noroeste da Argentina (Meira, 2010). 

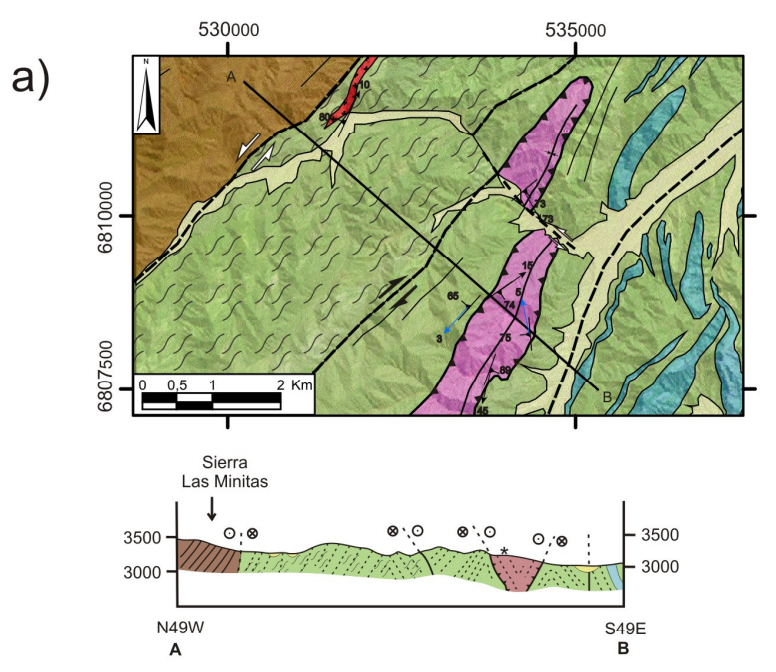

c)
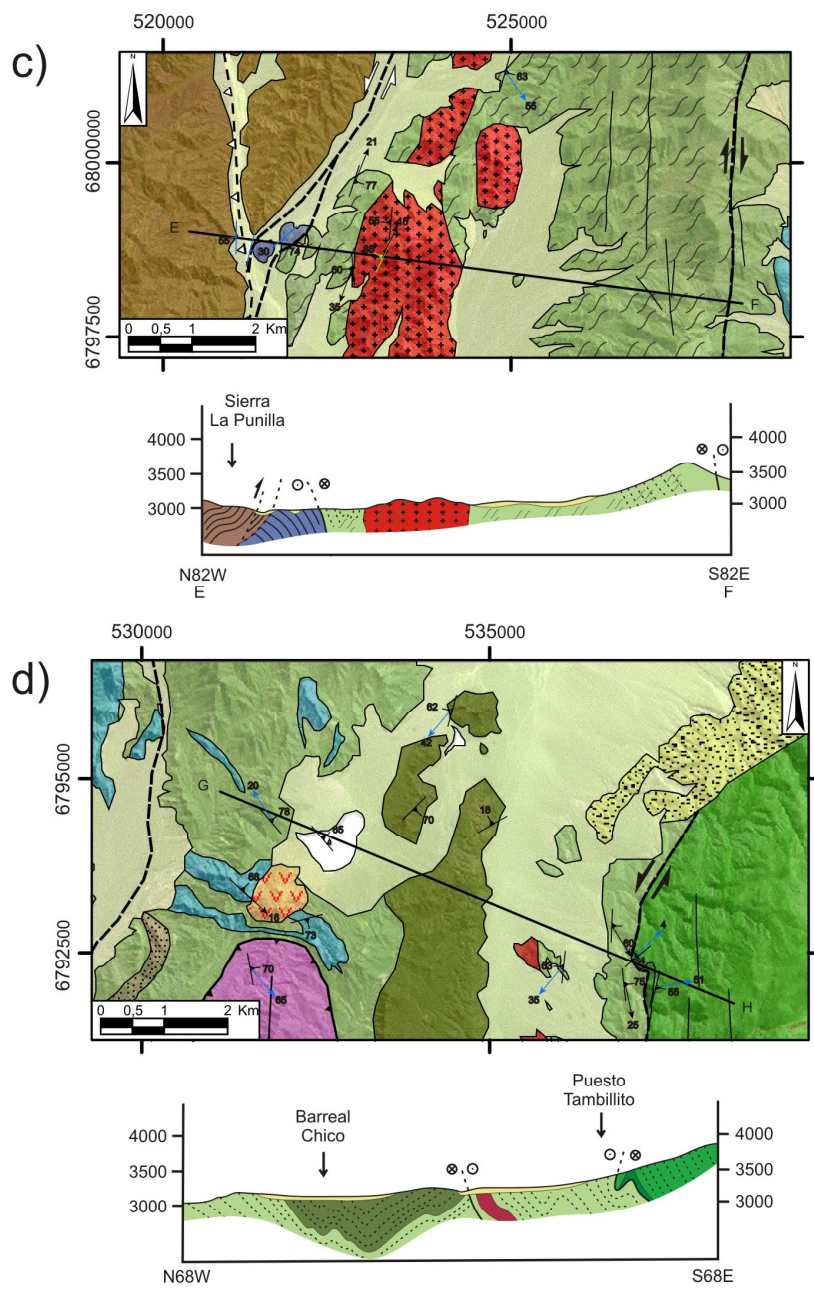
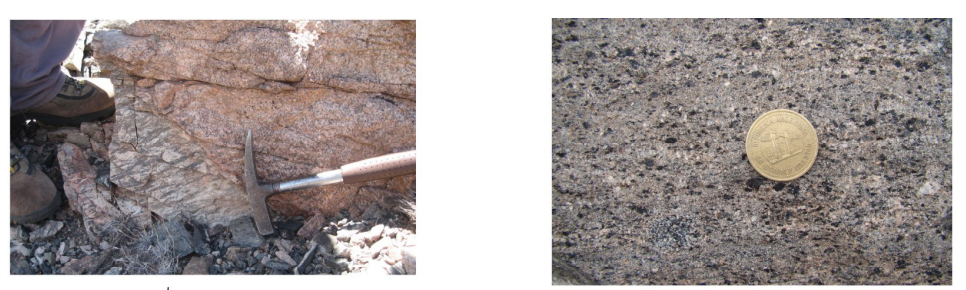

b)

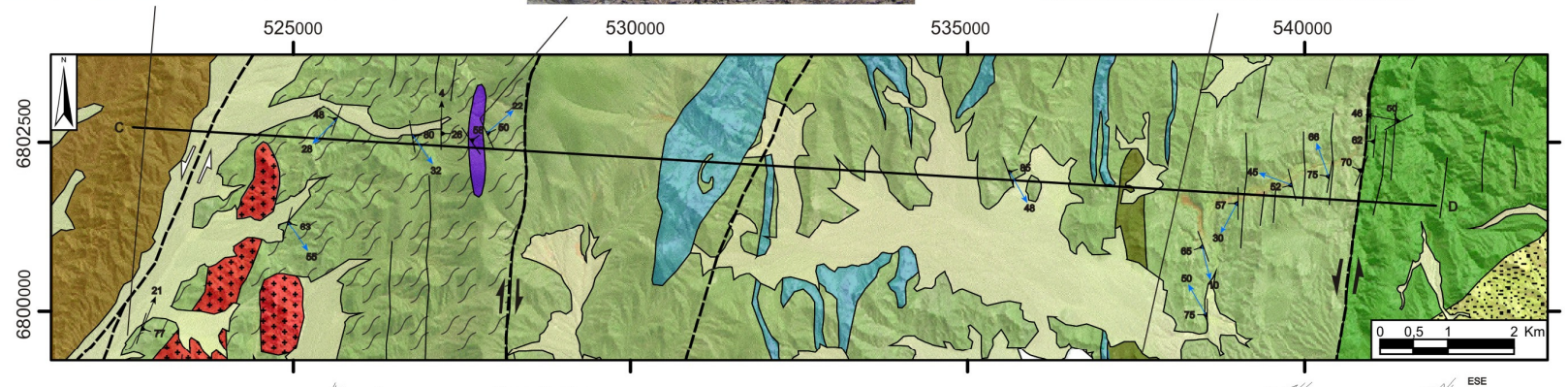

LEGENDA

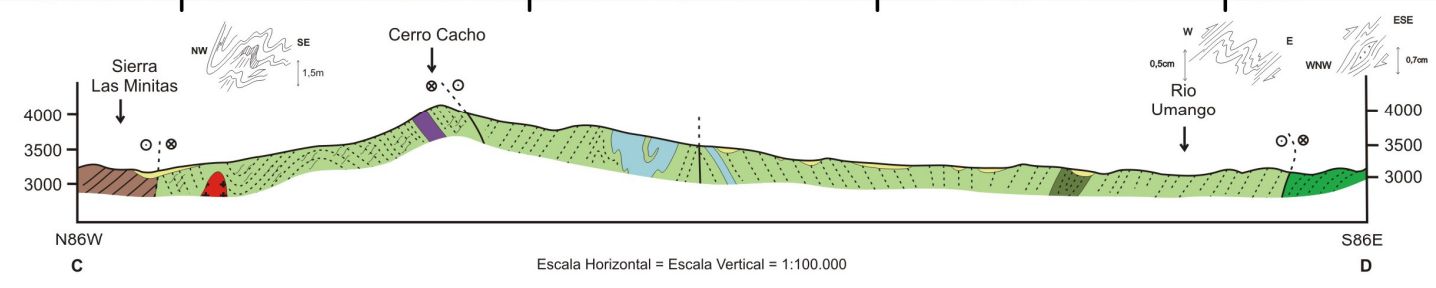

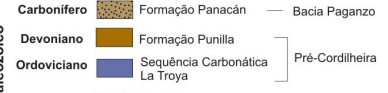

Siluriano : Grantio

Ordoviciano Grantito El Peñon ?

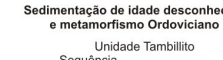

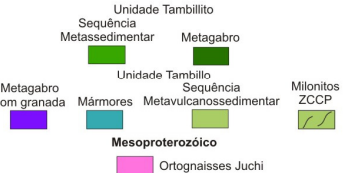
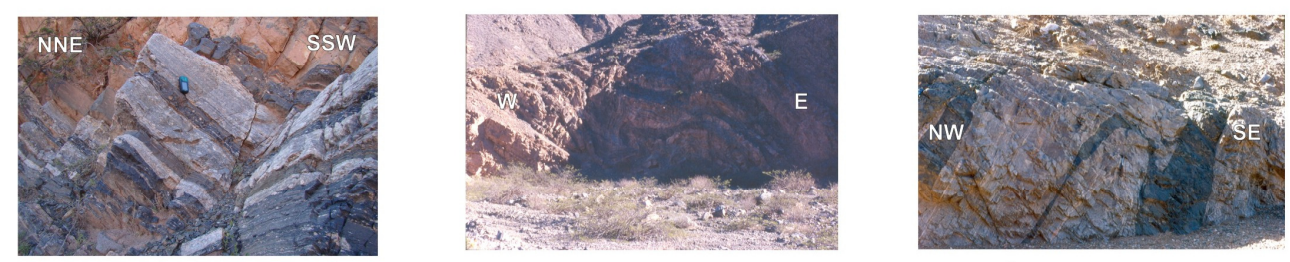

e)

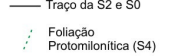

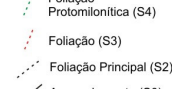

- Foliagăo Principal (S2)
Acamadamento (30)

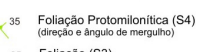

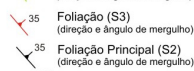

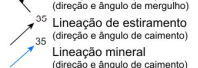

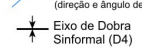

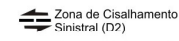

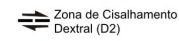

结 Zona de cisalhamentio

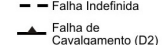

Cavalgamento (102)
$-\triangle$ Fana de Cavalagamento
Cenozica

- - - Fanala Nomal (02)

A-B Seçä Geolobica
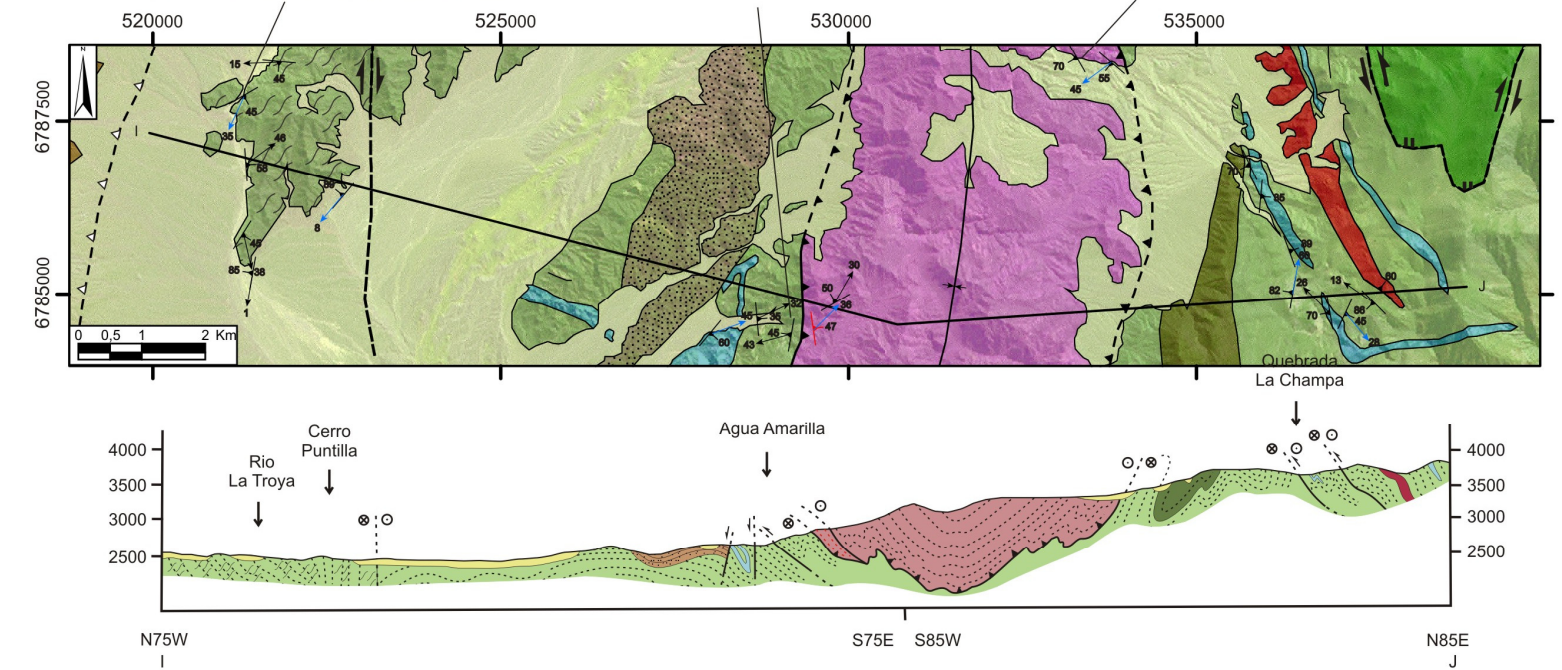

Escala Horizontal $=$ Escala Vertical $=1: 100.000$

Anexo 2 - Evolução estrutural da Sierra de Umango, Sierras Pampeanas Ocidentais, Noroeste da Argentina (Meira, 2010). 


\begin{tabular}{|c|c|c|c|c|c|c|c|c|c|}
\hline Pontos & UTM-N & UTM-E & S-TIPO & S-DIR & S-DIP & L-TIPO & L-DIR & L-DIP & Litotipos \\
\hline \multirow{6}{*}{ UM-401 } & \multirow{6}{*}{6790620} & \multirow{6}{*}{530325} & Fol (banda/o) & 90 & 30 & Lm & 35 & 19 & \multirow{6}{*}{$\begin{array}{l}\text { gnaisses máticos gabróicos com mobilizados leucocráticos throndjemíticos a graníticos } \mathrm{c} / \text { Bt e } \\
\text { Grt }\end{array}$} \\
\hline & & & Fol (banda/o) & 140 & 25 & & & & \\
\hline & & & Fol (banda/o) & 45 & 30 & $\operatorname{Lm}(\mathrm{PI})$ & 35 & 30 & \\
\hline & & & Fol (banda/o) & 50 & 32 & & & & \\
\hline & & & Fol (banda/o) & 85 & 25 & & & & \\
\hline & & & Fol (banda/o) & 80 & 26 & & & & \\
\hline \multirow{7}{*}{ UM-402 } & \multirow{7}{*}{6791017} & \multirow{7}{*}{531354} & Fol (banda/o) & 160 & 85 & & & & \multirow{7}{*}{ gnaisses tonalíticos a Amph com níveis de Grt gnaisses máficos } \\
\hline & & & Fol (banda/o) & 338 & 68 & & & & \\
\hline & & & \begin{tabular}{|l} 
Fol (banda/o) \\
\end{tabular} & 342 & 82 & & & & \\
\hline & & & Fol (banda/o) & 352 & 50 & & & & \\
\hline & & & Fol (banda/o) & 20 & 60 & $\mathrm{Lm}$ & 300 & 30 & \\
\hline & & & Fol (banda/o) & 10 & 55 & Lm & 310 & 25 & \\
\hline & & & Fol (banda/o) & 325 & 45 & Lm (Felds) & 295 & 32 & \\
\hline \multirow{5}{*}{ UM-403 } & \multirow{5}{*}{6790339} & \multirow{5}{*}{531596} & Fol (banda/o) & 10 & 59 & & & & \multirow{5}{*}{ gnaisses tonalíticos com Grt e Amph } \\
\hline & & & Fol (banda/o) & 10 & 65 & & & & \\
\hline & & & Fol (banda/o) & 25 & 69 & & & & \\
\hline & & & Fol (banda/o) & 20 & 70 & $\operatorname{Lm}$ (Felds) & 295 & 73 & \\
\hline & & & Fol (banda/o) & 360 & 60 & Lm (Felds) & 340 & 52 & \\
\hline \multirow{7}{*}{ UM-404 } & \multirow{7}{*}{6789477} & & Fol (banda/o) & 248 & 65 & & & & \multirow{7}{*}{$\begin{array}{l}\text { metamargas com alternância de níveis + impuros, níveis + foliados a Bt e níveis carbonáticos + } \\
\text { puros }\end{array}$} \\
\hline & & & Fol (banda/o) & 45 & 87 & & & & \\
\hline & & & Fol (banda/o) & 18 & 82 & & & & \\
\hline & & 531999 & Fol (banda/o) & 355 & 85 & & & & \\
\hline & & & Fol (banda/o) & 23 & 74 & & & & \\
\hline & & & Fol (banda/o) & 20 & 73 & & & & \\
\hline & & & Fol (banda/o) & 35 & 70 & & & & \\
\hline \multirow{2}{*}{ UM-405 } & \multirow{2}{*}{6789045} & 532350 & Fol (banda/o) & 210 & 60 & & & & \multirow{2}{*}{ intercalações de rochas carbonáticas nos gnaisses máficos } \\
\hline & & 532350 & Fol (banda/o) & 220 & 70 & & & & \\
\hline \multirow{2}{*}{ UM-406 } & \multirow[t]{2}{*}{6788488} & \multirow[t]{2}{*}{533160} & Fol (banda/o) & 240 & 70 & & & & \multirow{2}{*}{ Grt gnaisse tonalítico cortado por dique máfico } \\
\hline & & & Fol (banda/o) & 245 & 74 & & & & \\
\hline UM-407 & 6786973 & 535589 & Fol (banda/o) & 95 & $\frac{45}{48}$ & & & & hidrotermalito??? Rocha rica em epidoto e feldspato róseo \\
\hline & & & $\begin{array}{l}\text { Fol (banda/o) } \\
\text { Fol (band }\end{array}$ & $\frac{105}{290}$ & $\begin{array}{ll}48 \\
88 \\
\end{array}$ & $\mathrm{Lm}$ & 360 & 40 & \\
\hline & & & Fol (banda/o) & 280 & 82 & Lm (Felds) & 20 & 60 & \\
\hline UM-408 & 6785093 & 536530 & Fol (banda/o) & 280 & 90 & $\mathrm{Lm}$ & 10 & 57 & mármores e rochas máficas dobradas conjunta/e \\
\hline & & & & 95 & 90 & eixo B & 175 & 40 & \\
\hline & & & PA & 125 & 59 & eixo B & 180 & 55 & \\
\hline & & & Fol & 275 & 64 & & & & \\
\hline & & & Fol & 276 & 63 & $\mathrm{Lm}$ & 220 & 35 & \\
\hline & & & Fol & 260 & 70 & & $2<0$ & & \\
\hline & & & Fol & 255 & 70 & & & & metapsamito quartzoso com Bt e Grt, presença de veios concordantes e deformados de \\
\hline UM-409 & 6792419 & 536012 & Fol & 100 & 68 & $\mathrm{Lm}$ & 10 & & leucogranito roxo, foliado c/ Grt (granito El Peñon ?!) - granito milonitizado e ocorrem anfibolitos \\
\hline & & & Fol & 70 & 62 & $\operatorname{Lm}($ Felds) & 145 & 58 & foliados \\
\hline & & & Fol & 250 & 80 & Lm & 173 & 60 & \\
\hline & & & Fol & 255 & 87 & $\mathrm{Lm}$ & 170 & 56 & \\
\hline & & & Fol & 260 & 76 & $\mathrm{Lm}$ & 162 & 61 & \\
\hline
\end{tabular}




\begin{tabular}{|c|c|c|c|c|c|c|c|c|c|}
\hline Pontos & UTM-N & UTM-E & S-TIPO & S-DIR & S-DIP & L-TIPO & L-DIR & L-DIP & \multirow{7}{*}{ seq de mármores com intercalaçōes de granito milonitizado } \\
\hline \multirow{6}{*}{ UM-410 } & \multirow{6}{*}{6801961} & \multirow{6}{*}{535717} & Fol & 235 & 70 & & & & \\
\hline & & & Fol & 250 & 63 & & & & \\
\hline & & & Fol & 70 & 85 & $L \mathrm{Lm}$ & 150 & 48 & \\
\hline & & & Fol & 68 & 83 & $\mathrm{Lm}$ & 152 & 42 & \\
\hline & & & Fol & 47 & 77 & $\mathrm{Lm}$ & 148 & 25 & \\
\hline & & & Fol & 70 & 76 & & & & \\
\hline \multirow{6}{*}{ UM-411 } & \multirow{6}{*}{6796117} & \multirow{6}{*}{534427} & Fol & 300 & 53 & & & & \multirow{6}{*}{$\begin{array}{c}\text { seq de rochas cálciossilicáticas c/ variações + quartzosas e + antibolíticas. Ocorrem Grt } \\
\text { paranfibolito e Grt granito dobrado e foliado }\end{array}$} \\
\hline & & & Fol & 285 & 59 & & & & \\
\hline & & & Fol & 312 & 50 & & & & \\
\hline & & & Fol & 285 & 62 & Lm (Felds) & 220 & 42 & \\
\hline & & & Fol & 302 & 73 & $\mathrm{Lm}$ & 225 & 35 & \\
\hline & & & Fol & 303 & 80 & $L \mathrm{~m}$ & 223 & 45 & \\
\hline \multirow{3}{*}{ UM-412 } & \multirow{3}{*}{6799828} & \multirow{3}{*}{538553} & Fol (banda/o) & 265 & 75 & & 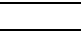 & + & \multirow{3}{*}{ seq de rochas metacarbonáticas com frequentes intercalaçōes de lentes de rochas metamáticas } \\
\hline & & & Fol (banda/o) & 265 & 73 & & & & \\
\hline & & & PA (D2) ?? & 60 & 65 & eixo B (D2) & 355 & 6 & \\
\hline \multirow{2}{*}{ UM-413 } & 6800412 & 538690 & Fol (banda/o) & 90 & 90 & Lm (Qtz) & 180 & 9 & \multirow{2}{*}{ mica xisto muscovítico com intercalaçoes de pegmatito grosso foliado } \\
\hline & $000+16$ & 300050 & Fol (banda/o) & 85 & 81 & Lm (Qtz) & 170 & 33 & \\
\hline \multirow[b]{2}{*}{ UM-414 } & \multirow{2}{*}{6801060} & \multirow{2}{*}{538395} & Fol (banda/o) & 250 & 65 & Lm & 166 & 10 & \multirow{2}{*}{ seq de rochas cálciossilicáticas, anfibolitos, metacarbonatos e metamáficas } \\
\hline & & & \begin{tabular}{|l} 
Fol (banda/o) \\
\end{tabular} & 260 & 63 & $L \mathrm{~m}$ & 175 & 20 & \\
\hline \multirow{7}{*}{ UM-415 } & \multirow{7}{*}{6792155} & & Fol & 345 & 70 & & & & \multirow{7}{*}{ granodiorito a tonalitos foliados com intercalações de rochas metabásicas (ortognaisses!?!) } \\
\hline & & & Fol & 25 & 70 & & & & \\
\hline & & & Fol & 350 & 75 & & & & \\
\hline & & 531655 & Fol & 80 & 70 & Lm & 140 & 65 & \\
\hline & & & PA & 150 & 70 & eixo B & 75 & 59 & \\
\hline & & & $\mathrm{PA}$ & 172 & 80 & eixo B & 95 & 75 & \\
\hline & & & PA & 310 & 80 & & & & \\
\hline \multirow{4}{*}{ UM-416 } & \multirow{4}{*}{6786544} & \multirow{4}{*}{522770} & Smilon & 303 & 77 & & & & \\
\hline & & & Smilon & 310 & 90 & $\operatorname{Lm}$ (Felds) & 220 & 8 & \\
\hline & & & Smilon & 332 & 70 & Le & 242 & 18 & gnaisses protomilioniticos \\
\hline & & & Smilon & 330 & 73 & Le & 228 & 23 & \\
\hline UM-417 & 6786637 & 522689 & Smilon & 302 & $90 \mid$ & Le & $\frac{210}{232}$ & 31 & seq de mármores brechados, metabásicas/máficas e Grt gnaisse milonítico (contato??) \\
\hline & & & PA (dobras abertas) & 262 & 63 & eixo B & 233 & 65 & \\
\hline UM-418 & 6785778 & 521227 & Smilon & 110 & 73 & Lm (Felds) & 195 & 15 & gnaisses miloníticos dobrados com Grt de até $1 \mathrm{~cm}$ de diâmetro \\
\hline & & & Smilon & 100 & 82 & $\mathrm{Lm}$ & 190 & 31 & \\
\hline & & & Smilon & 120 & $\frac{60}{50}$ & Le & $\frac{75}{55}$ & 50 & \\
\hline & & & Smilon & 115 & 50 & Le & 55 & 32 & \\
\hline & & & Smilon & 120 & 50 & Le & 70 & 50 & rochas miloníticas com bandas protomiloníticas a ultramiloníticas. Ocorrem bandas centimétricas \\
\hline UM-419 & 6787440 & 521230 & Smilon & 145 & 42 & Le & 135 & 45 & de pegmatóide protomilonítico com augens de FK, rosa a esbranquiçado \\
\hline & & & Smilon & 147 & 42 & Le & 130 & 43 & \\
\hline & & & Smilon & 145 & 50 & Le & 140 & 50 & \\
\hline
\end{tabular}




\begin{tabular}{|c|c|c|c|c|c|c|c|c|}
\hline Pontos & UTM-N & UTM-E & S-TIPO & S-DIR & S-DIP & L-TIPO & \begin{tabular}{l|l|} 
L-DIR & L-DIP \\
\end{tabular} & Litotipos \\
\hline \multirow{29}{*}{ UM-500 } & \multirow{29}{*}{6784287} & \multirow{29}{*}{527982} & Smilon & 130 & 50 & $\operatorname{Lm}(\mathrm{L} 2)$ & \begin{tabular}{|r|r|}
70 & 45 \\
\end{tabular} & \multirow{29}{*}{$\begin{array}{l}\text { Plag-Bt xisto cinza escuro, gnaisse fino c/ FK (metagranitóíde?metaarcósio?), Grt-Ms-Bt-Qtz xisto } \\
\text { feldspático, Ms-Bt metarcóseo, mármores brancos, rochas calciossilicáticas grossas a epidoto, } \\
\text { Grt, Qtz e Feldsporfiroblásticos (TIc e Amph) e Grt-Bt quartzito fino/ metassiltito/ metarenito muito } \\
\text { fino }\end{array}$} \\
\hline & & & Smilon & 50 & 45 & Lm (felds) & \begin{tabular}{|l|l|}
50 & 45 \\
\end{tabular} & \\
\hline & & & & & & Lmilon (L2) & \begin{tabular}{l|l|}
105 & 40 \\
\end{tabular} & \\
\hline & & & S2 (// banda/o milon) & 80 & & L2 & \begin{tabular}{|l|l|}
50 & 20 \\
\end{tabular} & \\
\hline & & & xistosi// obla & 35 & 20 & Le & \begin{tabular}{|l|l|}
65 & 15 \\
\end{tabular} & \\
\hline & & & & & & Lb2 & \begin{tabular}{l|r|}
42 & 14 \\
\end{tabular} & \\
\hline & & & & & & eixo B (dobras recumbentes) & \begin{tabular}{|l|l|}
30 & 25 \\
\end{tabular} & \\
\hline & & & & & & eixo B (dobras recumbentes) & \begin{tabular}{|l|l|}
20 & 20 \\
\end{tabular} & \\
\hline & & & & & & eixo B (dobras recumbentes) & \begin{tabular}{|l|l|}
15 & 13 \\
\end{tabular} & \\
\hline & & & & & & eixo B (dobras recumbentes) & \begin{tabular}{|l|l|}
10 & 7 \\
\end{tabular} & \\
\hline & & & & & & L2 (charneira deformada-bainha) & \begin{tabular}{|r|r|}
2 & 10 \\
\end{tabular} & \\
\hline & & & & & & L2 (charneira deformada-bainha) & \begin{tabular}{|l|l|}
30 & 20 \\
\end{tabular} & \\
\hline & & & & & & L2 (charneira deformada-bainha) & $\begin{array}{cc}25 & 5 \\
\end{array}$ & \\
\hline & & & & & & L2 (charneira deformada-bainha) & $\begin{array}{ll}196 & 15 \\
196\end{array}$ & \\
\hline & & & & & & L2 (charneira deformada-bainha) & \begin{tabular}{|l|r|}
215 & 5 \\
\end{tabular} & \\
\hline & & & & & & L2 (charneira deformada-bainha) & $210 \quad 10 G$ & \\
\hline & & & & & & L3 & 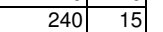 & \\
\hline & & & s2 & 350 & 65 & Lb2 & \begin{tabular}{|l|l|}
265 & 3 \\
\end{tabular} & \\
\hline & & & & & & Le & \begin{tabular}{|l|l|}
10 & 58 \\
\end{tabular} & \\
\hline & & & $\mathrm{S} 2$ & 295 & 75 & & & \\
\hline & & & s2 & 325 & 57 & & & \\
\hline & & & S2 & 325 & 63 & Le & \begin{tabular}{|l|l|}
5 & 53 \\
\end{tabular} & \\
\hline & & & $\mathrm{s} 2$ & 80 & 30 & & & \\
\hline & & & s2 & 45 & 25 & Lm (felds) & \begin{tabular}{|l|l|}
30 & 24 \\
\end{tabular} & \\
\hline & & & \begin{tabular}{|lll}
$S 2$ \\
$S 2$
\end{tabular} & $\frac{405}{105}$ & 37 & Lm (felds) & \begin{tabular}{l|l|}
50 & 22 \\
5
\end{tabular} & \\
\hline & & & s2 & 90 & 40 & & & \\
\hline & & & PA (D2?) & 35 & 20 & eixo B (dobra recumbente) & \begin{tabular}{|l|l|}
42 & 14 \\
\end{tabular} & \\
\hline & & & & & & Le & \begin{tabular}{c|c|}
65 & 15 \\
\end{tabular} & \\
\hline & & & & & & Le & \begin{tabular}{|l|l|}
8 & 30 \\
\end{tabular} & \\
\hline \multirow{3}{*}{ UM-501 } & \multirow{3}{*}{6784492} & \multirow{3}{*}{528390} & $\mathrm{~S} 0=\mathrm{S} 2$ & 100 & 90 & Le & \begin{tabular}{|l|r|}
20 & 80 \\
\end{tabular} & \multirow{3}{*}{ rochas calciosilicáticas e mármores } \\
\hline & & & So & 335 & & $L b$ & \begin{tabular}{|l|l|}
10 & 2 \\
\end{tabular} & \\
\hline & & & S2 & $\frac{305}{100}$ & 85 & LLO & 10 & \\
\hline \multirow{19}{*}{ UM-502 } & \multirow{19}{*}{6784522} & \multirow{19}{*}{528772} & $\mathrm{~S} 2=\mathrm{S} 0$ & 75 & 30 & $\operatorname{Lint}(\mathrm{Bt})=\mathrm{Lb} 2$ & \begin{tabular}{l|l|}
45 & 25 \\
\end{tabular} & \multirow{19}{*}{$\begin{array}{l}\text { intercalações de psamito cinza imaturo com lentes a Amph?, boudins de granito róseo grosso } \\
\text { foliado, quartzito imaturo a Bt e Plag, provável Amph e Chl sin-foliação e } 20 \mathrm{~cm} \text { de hornblendito } \\
\text { verde escuro de gran média-grossa }\end{array}$} \\
\hline & & & & & & $L \min (\mathrm{Bt})$ & \begin{tabular}{|l|l|}
110 & 35 \\
\end{tabular} & \\
\hline & & & & & & $\frac{\mathrm{Lb} 2=\mathrm{Le}}{\mathrm{Lb}}$ & \begin{tabular}{|l|l|}
60 & 40 \\
100
\end{tabular} & \\
\hline & & & $\mathrm{s} 2$ & 100 & 50 & $\frac{L D L=L E}{L \operatorname{Lin}(B t)}$ & $\begin{array}{ll}60 & 40 \\
65 & 38 \\
\end{array}$ & \\
\hline & & & S2 & 90 & 30 & L3 (cren) & \begin{tabular}{|l|l|}
30 & 15 \\
\end{tabular} & \\
\hline & & & S2 & 115 & 50 & $L 2=L e$ & \begin{tabular}{|l|l|}
40 & 25 \\
\end{tabular} & \\
\hline & & & & & & Le & \begin{tabular}{|l|l|}
20 & 33 \\
\end{tabular} & \\
\hline & & & S2 (transporte cavalgamento!) & 85 & & Le & \begin{tabular}{|c|c|}
65 & 32 \\
\end{tabular} & \\
\hline & & & S2 & 105 & 70 & & & \\
\hline & & & S2 & 50 & 32 & Lb & \begin{tabular}{l|l}
45 & 30 \\
\end{tabular} & \\
\hline & & & S2 & 120 & 72 & Lb & 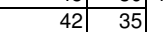 & \\
\hline & & & 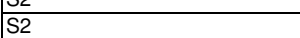 & $\frac{120}{115}$ & $\frac{74}{47}$ & & & \\
\hline & & & $\mathrm{S} 2$ & 110 & 47 & & & \\
\hline & & & xistosi// oblq & 35 & 15 & & & \\
\hline & & & 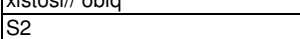 & $\frac{30}{110}$ & & Le & \begin{tabular}{|l|l|}
60 & 40 \\
\end{tabular} & \\
\hline & & & & & & L3 & \begin{tabular}{|c|c|}
30 & 15 \\
\end{tabular} & \\
\hline & & & & & & L3 & \begin{tabular}{|l|l|}
50 & 30 \\
\end{tabular} & \\
\hline & & & & & & Lmin (Bt) & \begin{tabular}{|l|l|}
55 & 38 \\
\end{tabular} & \\
\hline & & & s2 & 55 & 45 & Lm & \begin{tabular}{|l|l|}
20 & 30 \\
\end{tabular} & \\
\hline
\end{tabular}




\begin{tabular}{|c|c|c|c|c|c|c|c|c|}
\hline Pontos & UTM-N & UTM-E & S-TIPO & S-DIR & S-DIP & L-TIPO & \begin{tabular}{|l|l|} 
L-DIR & L-DIP \\
\end{tabular} & Litotipos \\
\hline \multirow{24}{*}{ UM-503 } & \multirow{24}{*}{6784535} & \multirow{24}{*}{528977} & S2 & 60 & 45 & Lmin (Plag) & \begin{tabular}{ll|}
90 & 40 \\
\end{tabular} & \multirow{24}{*}{$\begin{array}{l}\text { metagrauvacas c/ veios estirados de Qtz intercalados em mármores, Bt-Qtz anfibolito cinza fina/e } \\
\text { bandado, leitos de Grt-Qtz antibolito de gran média e Qtz anfibolito preto de gran média-fina, } \\
\text { intercalados em mármore creme, intensa/e dobrado }\end{array}$} \\
\hline & & & PA & 100 & 40 & eixo B & \begin{tabular}{|l|l|}
40 & 32 \\
\end{tabular} & \\
\hline & & & PA & 105 & & eixo B & \begin{tabular}{l|l|}
45 & 30 \\
\end{tabular} & \\
\hline & & & & & & eixo B & \begin{tabular}{|l|l|}
42 & 30 \\
\end{tabular} & \\
\hline & & & & & & Lanterior & \begin{tabular}{l|l|}
0 & 45 \\
\end{tabular} & \\
\hline & & & PA (D2 isoclinal e desarmonico) & 50 & 37 & eixo B & \begin{tabular}{|l|l|}
80 & 20 \\
\end{tabular} & \\
\hline & & & \begin{tabular}{|l|l} 
PA (D2 isoclinal e desarmonico) \\
\end{tabular} & 107 & 25 & eixo B & \begin{tabular}{|l|l|}
55 & 3 \\
\end{tabular} & \\
\hline & & & S2 & 290 & 75 & & & \\
\hline & & & S2 & 108 & 90 & & & \\
\hline & & & S2 & 340 & 45 & & & \\
\hline & & & S2 & 50 & 36 & & & \\
\hline & & & S2 & 65 & 48 & Le (dobrada) & \begin{tabular}{l|l}
0 & 45 \\
\end{tabular} & \\
\hline & & & S2 & 0 & 45 & Le (dobrada) & \begin{tabular}{|l|l|}
340 & 52 \\
\end{tabular} & \\
\hline & & & S2 & 45 & 26 & Le (dobrada) & \begin{tabular}{|l|l|}
355 & 82 \\
\end{tabular} & \\
\hline & & & S2 & 65 & 24 & Le (dobrada) & \begin{tabular}{|l|l|}
325 & 86 \\
\end{tabular} & \\
\hline & & & S2 & 310 & 87 & & & \\
\hline & & & S2 & 315 & 79 & & & \\
\hline & & & S2 & 340 & 60 & & & \\
\hline & & & S2 & 350 & 50 & & & \\
\hline & & & $\mathrm{s} 2$ & 110 & 37 & & & \\
\hline & & & S2 & 112 & 53 & & & \\
\hline & & & S2 & 90 & 40 & & & \\
\hline & & & $\mathrm{PA}$ & 85 & 40 & eixo B & \begin{tabular}{l|l|}
45 & 33 \\
\end{tabular} & \\
\hline & & & & & & eixo B & 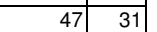 & \\
\hline \multirow{13}{*}{ UM-504 } & \multirow{13}{*}{6784556} & \multirow{13}{*}{529133} & S2 & 280 & 45 & $\mathrm{~L} 2$ & \begin{tabular}{l|l|}
255 & 45 \\
\end{tabular} & \multirow{13}{*}{$\begin{array}{l}\text { anfibolitos finos cinza escuros placosos, intensa/e dobrados (D2 ou D3?), boudins métricos de } \\
\text { Grt-Qtz-Plag anfibolito placoso, local/e porfiroblástico, intenso dobramento isopaco no extrado e } \\
\text { claramente vergente para W no intrado (D3!?)intercalaçōes de decim a métricas de mármore e } \\
\text { de calciossilicáticas, mergulho do PA3 de cerca de } 50 \text { graus para NE e D4 eixo B= N45 ou } \\
\text { xistosil// oblq D3?? }\end{array}$} \\
\hline & & & S2 & 280 & 30 & $\mathrm{L2}$ & \begin{tabular}{|l|l|}
260 & 30 \\
\end{tabular} & \\
\hline & & & S2 & 270 & 20 & $\mathrm{~L} 2$ & \begin{tabular}{|l|l|}
250 & 18 \\
\end{tabular} & \\
\hline & & & S2 & 265 & & $\mathrm{~L} 2$ & \begin{tabular}{l|l|}
270 & 2 \\
\end{tabular} & \\
\hline & & & S2 & 95 & 12 & $\mathrm{~L} 2$ & \begin{tabular}{|l|l|}
80 & 8 \\
\end{tabular} & \\
\hline & & & S2 & 110 & & L2 & \begin{tabular}{|l|l|}
85 & 13 \\
\end{tabular} & \\
\hline & & & PA (D2/D3?) & 95 & 80 & eixo B & \begin{tabular}{|l|l|}
330 & 20 \\
\end{tabular} & \\
\hline & & & & & & L2 & \begin{tabular}{l|l|}
115 & 43 \\
\end{tabular} & \\
\hline & & & & & & $\underline{L 2}$ & \begin{tabular}{ll|}
285 & 2 \\
\end{tabular} & \\
\hline & & & & & & L2 & \begin{tabular}{|l|l|}
300 & 65 \\
\end{tabular} & \\
\hline & & & PA & 50 & 56 & Lb2 & \begin{tabular}{|l|l|}
50 & 50 \\
\end{tabular} & \\
\hline & & & PA & 48 & 55 & eixo B & \begin{tabular}{l|l|}
322 & 11 \\
\end{tabular} & \\
\hline & & & falha inversa (S3?) & 100 & 68 & & & \\
\hline \multirow{8}{*}{ UM-505 } & \multirow{8}{*}{6784555} & \multirow{8}{*}{529462} & S2 & 95 & 55 & Lcren & \begin{tabular}{l|l|}
40 & 40 \\
\end{tabular} & \multirow{8}{*}{$\begin{array}{l}\text { Bt-Hbl gnaisse grosso, cinza claro, bandado. Intercalam-se metagrauvacas granoblásticas: Grt- } \\
\text { Hbl-Bt-Plag gnaisse }\end{array}$} \\
\hline & & & S2 & 60 & 67 & L2 & \begin{tabular}{l|l|}
35 & 60 \\
\end{tabular} & \\
\hline & & & S2 & 70 & 67 & Lmin (felds) & \begin{tabular}{l|l|}
35 & 57 \\
\end{tabular} & \\
\hline & & & ( t & 10 & + & Lmin (felds) & \begin{tabular}{|l|r|}
30 & 50 \\
\end{tabular} & \\
\hline & & & S2 & 20 & 65 & Lb & \begin{tabular}{|l|l|}
325 & 60 \\
\end{tabular} & \\
\hline & & & S2 (amostra A) & 95 & 50 & & + & \\
\hline & & & S2 (amostra B) & 105 & 48 & $L \operatorname{Lin}(\mathrm{Hbl})$ & \begin{tabular}{|l|l|}
35 & 30 \\
3
\end{tabular} & \\
\hline & & & S2 (amostra C) & 90 & 45 & $L \operatorname{Lin}(\mathrm{Hbl})$ & \begin{tabular}{|l|l|}
30 & 26 \\
\end{tabular} & \\
\hline \multirow{5}{*}{ UM-506 } & \multirow{5}{*}{6784540} & & S3? (transposição) & 85 & 70 & Le & \begin{tabular}{l|l|}
40 & 65 \\
\end{tabular} & \multirow{5}{*}{$\begin{array}{l}\text { Grt-Hbl gnaisse bandado cinza, granito róseo grosso hololeucocrático a Bt e leitos centim de } \\
\text { gnaisses calciossilicáticos }\end{array}$} \\
\hline & & & \begin{tabular}{|l} 
S2? (bandamento) \\
\end{tabular} & 65 & 79 & $\operatorname{Lm}$ (Amph) & $\begin{array}{ll}355 & 40 \\
\end{array}$ & \\
\hline & & 529537 & S2? (bandamento) & 85 & 75 & $\operatorname{Lm}$ (Felds) & \begin{tabular}{|l|l|}
30 & 56 \\
\end{tabular} & \\
\hline & & & boudin/neck (fendas "T") & 0 & 80 & & \begin{tabular}{l|l|} 
\\
\end{tabular} & \\
\hline & & & PA (D3?) & 40 & 64 & eixo B (D3?) & \begin{tabular}{l|l|}
320 & 60 \\
\end{tabular} & \\
\hline
\end{tabular}




\begin{tabular}{|c|c|c|c|c|c|c|c|c|}
\hline Pontos & UTM-N & UTM-E & S-TIPO & S-DIR & S-DIP & L-TIPO & \begin{tabular}{l|l|} 
L-DIR & L-DIP \\
\end{tabular} & Litotipos \\
\hline \multirow{8}{*}{ UM-507 } & \multirow{8}{*}{6784525} & \multirow{8}{*}{529581} & S3? (transposição) & 82 & 47 & Lmin (felds)=Le & \begin{tabular}{|l|l|}
45 & 36 \\
\end{tabular} & \multirow{8}{*}{$\begin{array}{c}\text { Hbl-Bt gnaisse bandado, bandas centimétricas antibolíticas, Grt-Bt-Plag-Qtz gnaisse alternado o/ } \\
\text { Grt-Plag-Qtz-Bt xisto (metagrauvaca) } \mathrm{e}=\text { gnaisse calciossilicático }(50 \mathrm{~cm})\end{array}$} \\
\hline & & & & & & $1 \min$ (Amph) & \begin{tabular}{|l|l|}
135 & 38 \\
\end{tabular} & \\
\hline & & & S3? (transposição) & 95 & 68 & Lmin (felds) & \begin{tabular}{|l|l|}
40 & 65 \\
\end{tabular} & \\
\hline & & & PA (D3?) & 55 & 60 & eixo B (D3?) & \begin{tabular}{|r|r|}
25 & 51 \\
\end{tabular} & \\
\hline & & & S3? (transposição) & 100 & 85 & Lmullion & \begin{tabular}{|l|l|}
80 & 80 \\
\end{tabular} & \\
\hline & & & & & & eixo B (intrafolial) & \begin{tabular}{|l|l|}
26 & 63 \\
\end{tabular} & \\
\hline & & & & & & eixo B (intrafolial) & \begin{tabular}{|l|l|}
28 & 70 \\
\end{tabular} & \\
\hline & & & & & & eixo B (intrafolial) & \begin{tabular}{|l|l|}
75 & 48 \\
\end{tabular} & \\
\hline \multirow{15}{*}{ UM-508 } & \multirow{15}{*}{6784582} & \multirow{15}{*}{529657} & Smilon & 5 & 80 & Le & \begin{tabular}{ll|}
70 & 65 \\
\end{tabular} & \multirow{15}{*}{$\begin{array}{l}\text { Bt granito milonítico cinza, linear e grosso, porfiroclástico rosado e Bt-Hbl gnaisse cinza } \\
\text { equigranular médio homogêneo }\end{array}$} \\
\hline & & & S2 (dobra em bainha) & 345 & $\frac{30}{35}$ & Le & \begin{tabular}{|l|l|}
335 & 35 \\
\end{tabular} & \\
\hline & & & S2? (bandamento) & 80 & 15 & & & \\
\hline & & & S2? (bandamento) & 75 & 50 & & & \\
\hline & & & S2? - dobras sanfonadas & 275 & 70 & & & \\
\hline & & & S2? - dobras sanfonadas & $\frac{210}{60}$ & 75 & Lb (Hbl gnaisse) & \begin{tabular}{|l|l|}
145 & 25 \\
\end{tabular} & \\
\hline & & & PA (dobra do bandamento) & 35 & 70 & $\mathrm{Lb}$ & \begin{tabular}{l|l|}
110 & 86 \\
\end{tabular} & \\
\hline & & & s2? & 40 & 72 & & & \\
\hline & & & S2? & 15 & 72 & Lmin (Felds) & \begin{tabular}{l|l|}
60 & 62 \\
\end{tabular} & \\
\hline & & & S2? & 10 & 75 & Lmin (Felds) & \begin{tabular}{|l|l|}
85 & 60 \\
\end{tabular} & \\
\hline & & & $\mathrm{PA}$ & 38 & 70 & eixo B & \begin{tabular}{|l|l|}
310 & 38 \\
\end{tabular} & \\
\hline & & & S3? (transposição) & 30 & 60 & & & \\
\hline & & & 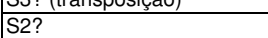 & 275 & 70 & Lmin (Felds) & \begin{tabular}{|l|l|}
120 & 70 \\
\end{tabular} & \\
\hline & & & S2? & 90 & 75 & Lmin (Felds) & \begin{tabular}{|l|l|}
15 & 60 \\
\end{tabular} & \\
\hline & & & Smilon & 85 & 55 & & & \\
\hline \multirow{18}{*}{ UM-509 } & \multirow{18}{*}{6784639} & \multirow{18}{*}{529722} & Smilon & 72 & 72 & & & \multirow{18}{*}{$\begin{array}{l}\text { milonito porfiroclástico a ultramilonito porfiroclastico dobrados!, filōes deformados de granito } \\
\text { pegmatóide vermelho e rocha vulcânica ácida vermelha amarronzada de gran muito fina c/ } \\
\text { fenocristais }\end{array}$} \\
\hline & & & Smilon & 290 & 65 & $L \operatorname{Lmin}(\mathrm{Bt})$ & 20 & \\
\hline & & & Smilon & 335 & 5 & Le & 25 & \\
\hline & & & \begin{tabular}{|l|l} 
Smilon \\
Smilon
\end{tabular} & \begin{tabular}{r|r}
305 \\
48
\end{tabular} & 53 & & 10 & \\
\hline & & & Smilon & 350 & 45 & Le & \begin{tabular}{|l|l|}
345 & 40 \\
\end{tabular} & \\
\hline & & & Smilon & 310 & 57 & $\mathrm{Lb}$ & \begin{tabular}{|l|l|}
7 & 10 \\
\end{tabular} & \\
\hline & & & Smilon & 298 & 77 & & & \\
\hline & & & Smilon & 30 & 35 & Le & 18 & \\
\hline & & & Smilon & 70 & 45 & $\mathrm{Le}$ & \begin{tabular}{|l|l|}
50 & 45 \\
\end{tabular} & \\
\hline & & & Smilon & 57 & 50 & Le & \begin{tabular}{|l|l|}
60 & 35 \\
\end{tabular} & \\
\hline & & & Smilon & 43 & 39 & Le & \begin{tabular}{|l|l|}
65 & 24 \\
\end{tabular} & \\
\hline & & & Smilon & 22 & 33 & Le & \begin{tabular}{|l|l|}
80 & 10 \\
\end{tabular} & \\
\hline & & & Smilon & 0 & 26 & Le & \begin{tabular}{|l|l|}
242 & 25 \\
\end{tabular} & \\
\hline & & & Smilon & 320 & 32 & Le & \begin{tabular}{|l|l|}
260 & 40 \\
\end{tabular} & \\
\hline & & & \begin{tabular}{|l} 
Smilon \\
Smont
\end{tabular} & 325 & 30 & & 200 & \\
\hline & & & Smilon & 295 & 49 & & & \\
\hline & & & PA (D3?) & 68 & 66 & eixo $B$ & 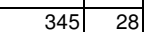 & \\
\hline & & & fraturamento & 155 & 35 & & & \\
\hline \multirow{4}{*}{ UM-510 } & \multirow{4}{*}{6784700} & \multirow{4}{*}{529817} & Smilon & 300 & 85 & Le & \begin{tabular}{|l|l|}
170 & 80 \\
\end{tabular} & \multirow{4}{*}{ milonito rico em Bt c/ domínios de Bt xisto e gnaissicos a $\mathrm{Hbl}$} \\
\hline & & & \begin{tabular}{|l} 
Smilon \\
\end{tabular} & 45 & 55 & Le & \begin{tabular}{|l|l|}
65 & 55 \\
\end{tabular} & \\
\hline & & & 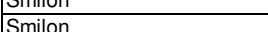 & $\frac{45}{50}$ & 66 & Le & $\begin{array}{l}00 \\
46\end{array}$ & \\
\hline & & & \begin{tabular}{|l} 
Smilon \\
Smilon
\end{tabular} & $\frac{50}{74}$ & $\frac{66}{70}$ & $\frac{L m i n(A m p n)}{L m i n(A m p h)}$ & \begin{tabular}{|l|l|}
40 & 60 \\
40 & 70 \\
\end{tabular} & \\
\hline \multirow{4}{*}{ UM-511 } & \multirow{4}{*}{6784658} & \multirow{4}{*}{529767} & Smilon & 330 & 50 & & $30 \quad 30$ & \multirow{4}{*}{$\begin{array}{l}\text { gnaisse a } \mathrm{Hbl} \text {, associado a boudins de rochas máticas finas, Bt granito rosado muito grosso, } \\
\text { intensa/e linear e milonitos }\end{array}$} \\
\hline & & & Smilon & 45 & 50 & & 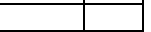 & \\
\hline & & & Smilon & 15 & 27 & Lm (Felds) & \begin{tabular}{|l|l|}
30 & 30 \\
\end{tabular} & \\
\hline & & & Smilon & 35 & 35 & & & \\
\hline
\end{tabular}




\begin{tabular}{|c|c|c|c|c|c|c|c|c|c|}
\hline Pontos & UTM-N & UTM-E & S-TIPO & S-DIR & S-DIP & L-TIPO & L-DIR & L-DIP & Litotipos \\
\hline UM-512 & 6785047 & 537808 & Fol (S2?!) & \begin{tabular}{r|r}
125 \\
85
\end{tabular} & $\begin{array}{ll}40 / \mathrm{L} \\
70 \mathrm{~L}\end{array}$ & Le & \begin{tabular}{r|r|}
25 \\
350
\end{tabular} & 0 & Bt granito gnaissico vermelho grosso e Bt granodiorito gnaisse linear cinza porfiroclástico \\
\hline \multirow{9}{*}{ UM-513 } & \multirow{9}{*}{6785000} & & Fol (S2?!) & 75 & $50 \mathrm{~L}$ & $\mathrm{Lb}$ & 350 & 2 & \multirow{9}{*}{$\begin{array}{l}\text { Grt-Ms-Bt-Plag-Qtz xisto cinza porfiroclástico, contato com granito gnaissico, no topo da } \\
\text { metabásica, para anfibolito? (titanita-Grt-BT-Ep-Plag-Hbl-Qtz), mármore branco e Bt-Amph xisto } \\
\text { bandado verde (metamarga?) }\end{array}$} \\
\hline & & & PA (fol dobrada) & 95 & 77 e & eixo B & 5 & 70 & \\
\hline & & & Fol (S2?!) & 55 & 75 & & & & \\
\hline & & & Fol (S2?!) & 55 & 60 & & & & \\
\hline & & 537685 & Fol (S2?!) & 36 & $60 \mathrm{LL}$ & Lm (Bt/Plag) & 276 & 22 & \\
\hline & & & Fol (S2?!) & 84 & $50 / \mathrm{L}$ & Le & & 5 & \\
\hline & & & Fol (S2?!) & 95 & $55 \mathrm{LL}$ & Le & 0 & 20 & \\
\hline & & & Fol (S2?!) & 65 & $85 \mathrm{~L}$ & Le & 345 & 17 & \\
\hline & & & Fol (S2?!) & 245 & $65 \mathrm{LL}$ & $\operatorname{Lm}(\mathrm{Bt})$ & 175 & 35 & \\
\hline \multirow{2}{*}{ UM-514 } & 6784858 & 537599 & Fol (S2?!)- acama/o//xistosi/// & $\begin{array}{ll}55 \\
10\end{array}$ & 80 & eixo & 270 & & \multirow{2}{*}{ metamargas, mármores, Bt-Amph xisto calciossilicático e anfibolito (orto?!!) } \\
\hline & 804000 & & $\begin{array}{l}\text { PA (U3? }) \\
\text { Fol (S2?!) }\end{array}$ & $\frac{10}{35}$ & & & 270 & 26 & \\
\hline \multirow{2}{*}{ UM-515 } & & & $\begin{array}{l}\text { Fol (S2?!) } \\
\text { Fo! (S2?!) }\end{array}$ & \begin{tabular}{r|r}
35 & 225 \\
225
\end{tabular} & $85 \mathrm{LL}$ & Lms//Lb & 130 & 3 & \multirow{2}{*}{$\begin{array}{l}\text { Ms-Qtz xisto cinza claro granolepidoblástico médio - c/ Grt-Ky?-Cld?-Bt e mármore, marga } \\
\text { calciossilicática, metabásica }\end{array}$} \\
\hline & $6 / 84847$ & $53 / 552$ & $\begin{array}{l}\text { Fol (S2!!) } \\
\text { S2//S0 }\end{array}$ & $\frac{225}{345}$ & $\frac{86}{70}$ & Le & 305 & 13 & \\
\hline \multirow{4}{*}{ UM-516 } & \multirow{4}{*}{6784779} & \multirow{4}{*}{537490} & S2 & 8 & $75 \mathrm{LL}$ & $\mathrm{Lb}$ & 95 & 5 & \multirow{4}{*}{ mármore branco rico em dobras intrafoliais, boudins de rocha metabásica fina e metamarga } \\
\hline & & & S2 & 357 & $75 \pi$ & Mullion b (anter?) & 125 & 55 & \\
\hline & & & $\mathrm{S} 2=\mathrm{S} 0$ & 10 & $75 \mathrm{LL}$ & 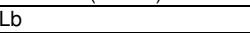 & 292 & 25 & \\
\hline & & & $\mathrm{S} 2=\mathrm{S} 0$ & 30 & 75 & & & & \\
\hline \multirow{7}{*}{ UM-517 } & \multirow{7}{*}{6784715} & \multirow{7}{*}{537406} & PA (D3?) & 255 & 66 & eixo B & 162 & 25 & \multirow{7}{*}{ granito gnaisse intercalado na sequência carbonática } \\
\hline & & & $\mathrm{S} 2=\mathrm{SO}$ & 80 & $85 \mathrm{LL}$ & Le & 165 & 20 & \\
\hline & & & Fol (Peñon) & 30 & $65 \mathrm{LL}$ & Lm (Felds) & 324 & 30 & \\
\hline & & & $\mathrm{S} 2$ & 80 & $65 \mathrm{~L}$ & Le & 175 & 33 & \\
\hline & & & S2 & 0 & $77 \mathrm{~L}$ & $\mathrm{Lb}$ & 280 & 20 & \\
\hline & & & Scren (S4?) & 85 & 85 & & & & \\
\hline & & & S2 & 30 & 75 & & & & \\
\hline \multirow{22}{*}{ UM-518 } & \multirow{22}{*}{6784680} & & S2 & 110 & $45 \mathrm{~L}$ & $\mathrm{Lb}$ & 198 & 15 & \\
\hline & & & S2 & 270 & $30 \mathrm{~L}$ & Lb3 & 192 & 18 & \\
\hline & & & S2 (Fol geral) & 177 & 30 & & & & \\
\hline & & & S2 & 210 & $35 \mathrm{~L}$ & $\mathrm{Lb}$ & 195 & 33 & \\
\hline & & & S2 & 250 & $45 \mathrm{LL}$ & $\mathrm{Lb}($ anter $)$ & 320 & 15 & \\
\hline & & & $\mathrm{S2}$ & 210 & $22 \mathrm{~L}$ & $\mathrm{Lb}($ anter) & 140 & 5 & \\
\hline & & & S2 & 170 & $20 \mathrm{~L}$ & $\mathrm{Lb}$ & 190 & 18 & \\
\hline & & & PA & 35 & $80 \mathrm{e}$ & eixo B & 120 & 5 & \\
\hline & & & & & solit & $\mathrm{Lb}$ & 30 & \begin{tabular}{|r|}
13 \\
\end{tabular} & \\
\hline & & & & & $\mathrm{at}$ & $\mathrm{Lb}$ & 190 & 25 & \\
\hline & & & & & 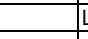 & $\operatorname{Lm}(\mathrm{Ms})$ & 200 & & \\
\hline & & 537317 & & & $t_{e}$ & eixo B & 80 & 14 & metamargas com Ms e Chl \\
\hline & & & & & $t e$ & eixo B & 90 & 18 & \\
\hline & & & S2 & 270 & 57 & & & & \\
\hline & & & $\mathrm{S} 2$ & 260 & 80 & & & & \\
\hline & & & S3 & 160 & $30 / 6$ & eixo B & 190 & 49 & \\
\hline & & & & & & $\mathrm{Lb}($ anter $)$ & 100 & & \\
\hline & & & S2 & 205 & $22 \mathrm{~L}$ & Lb(anter) & 276 & 7 & \\
\hline & & & & & & $\mathrm{Lb}$ & 195 & 20 & \\
\hline & & & S2 & 105 & $30 \mathrm{~L}$ & $\mathrm{Lm}(\mathrm{Chl})$ & 140 & 28 & \\
\hline & & & S2 & 100 & $60 \mathrm{~L}$ & Lb & 188 & 7 & \\
\hline & & & S2 & 125 & 35 & & & & \\
\hline & & & PA & 225 & 80 & eixo B & 140 & 20 & \\
\hline & & & PA (D3?) & 85 & 59 & eixo $B$ & 170 & 37 & \\
\hline & 6784572 & 537284 & & & & eixo B dobrado & 240 & 33 & \\
\hline UM-519 & 6784572 & 537284 & & & & eixo $B$ dobrado & 230 & 8 & metamargas intercaladas a camada métrica de metachert placoso creme amarronzado \\
\hline & & & & & & eixo $B$ dobrado & 60 & 30 & \\
\hline & & & & & & eixo B dobrado & 245 & 7 & \\
\hline
\end{tabular}




\begin{tabular}{|c|c|c|c|c|c|c|c|c|c|}
\hline Pontos & UTM-N & UTM-E & S-TIPO & S-DIR & S-DIP & L-TIPO & L-DIR & L-DIP & Litotipos \\
\hline \multirow{8}{*}{ UM-520 } & \multirow{8}{*}{6784533} & \multirow{8}{*}{537256} & $\mathrm{~S} 0=\mathrm{S} 2$ & 90 & 48 & & & & \multirow{8}{*}{ contato predominância de mármores e margas subordinadas (base do pacote) } \\
\hline & & & & & & eixo B & 190 & 36 & \\
\hline & & & $\mathrm{S} 0=\mathrm{S} 2$ & 250 & 55 & eixo $B$ & 260 & 49 & \\
\hline & & & $\mathrm{S} 0=\mathrm{S} 2$ & 260 & 80 & eixo B & 160 & & \\
\hline & & & $\mathrm{S} 0=\mathrm{S} 2$ & 270 & 57 & & & & \\
\hline & & & $\mathrm{S} 0=\mathrm{S} 2$ & 110 & 75 & & & & \\
\hline & & & $\mathrm{S} 0=\mathrm{S} 2$ & 105 & & eixo B & 40 & 15 & \\
\hline & & & $\mathrm{S} 0=\mathrm{S} 2$ & 300 & 60 & 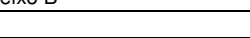 & 40 & | & \\
\hline \multirow{6}{*}{ UM-521 } & \multirow{6}{*}{6784567} & \multirow{6}{*}{537147} & $\mathrm{~S} 0=\mathrm{S} 2$ & 115 & 45 & Lb & 155 & 54 & \multirow{6}{*}{$\begin{array}{c}\text { mármores bandados (bandas de calcilutitos amarronzados) e dobrados, e intercalações até } \\
\text { métricas de metachert }\end{array}$} \\
\hline & & & \begin{tabular}{|l|l|} 
PA \\
\end{tabular} & 110 & 64 & eixo B & 150 & 55 & \\
\hline & & & & & & eixo B & 175 & \begin{tabular}{|l|l|}
51 \\
\end{tabular} & \\
\hline & & & & & & eixo $B$ & 260 & 36 & \\
\hline & & & & & & eixo $B$ & 95 & 31 & \\
\hline & & & & & & eixo B & 170 & 30 & \\
\hline \multirow{12}{*}{ UM-522 } & \multirow{12}{*}{6784844} & \multirow{12}{*}{536833} & $\mathrm{~S} 0=\mathrm{S} 2$ & 260 & 70 & $\mathrm{Lb}$ & 160 & 5 & \multirow{12}{*}{ predominância de mármores } \\
\hline & & & & 150 & 40 & Le & 200 & 27 & \\
\hline & & & $\mathrm{S} 0=\mathrm{S} 2$ & 100 & 18 & & & & \\
\hline & & & S2 (xistosi// PA) S3? & 260 & 70 & Lint (banda/o) & 170 & 10 & \\
\hline & & & $\mathrm{S} 0=\mathrm{S} 2$ & 250 & 67 & & & & \\
\hline & & & PA & 255 & 78 & eixo B & 170 & 8 & \\
\hline & & & & & & eixo B ("posterior") & 220 & 40 & \\
\hline & & & & & & eixo B ("anterior") & 165 & 5 & \\
\hline & & & PA (D3?) & 85 & 58 & eixo B & 20 & 20 & \\
\hline & & & S3? (falha inversa) & 85 & 70 & & & & \\
\hline & & & PA & 255 & 50 & eixo B & 195 & 5 & \\
\hline & & & & & & eixo B & 180 & 25 & \\
\hline \multirow{11}{*}{ UM-523 } & \multirow{11}{*}{6785054} & & $\mathrm{~S} 2=\mathrm{SO}$ & 120 & 45 & & & & \multirow{11}{*}{$\begin{array}{l}\text { quartzito cinza muito fino (metachert?) com lentes a Grt e Chl definindo lâminas, bandas e } \\
\text { vênulas vermelhas feldspáticas na fol. associadas ao Granito Peñon, metamargas com lentes de } \\
\text { calcarenitos marron, calcilutitos cinza e Chl-calcio xisto fino verde }\end{array}$} \\
\hline & & & $\mathrm{S} 2=\mathrm{S} 0$ & 95 & 75 & & & & \\
\hline & & & $\mathrm{S} 2=\mathrm{SO}$ & 285 & 80 & $\mathrm{Lb}$ & 185 & \begin{tabular}{|l|}
5 \\
5
\end{tabular} & \\
\hline & & & $\mathrm{S} 2=\mathrm{S} 0$ & 115 & & $\mathrm{Lb}$ & 205 & \begin{tabular}{|l|l|}
5 & 30 \\
\end{tabular} & \\
\hline & & & \begin{tabular}{|l}
$\mathrm{PA}$ (D3?) \\
\end{tabular} & 110 & 90 & eixo B & 12 & 13 & \\
\hline & & 536678 & \begin{tabular}{|l|}
$\mathrm{PA}(\mathrm{D} 3)$ \\
\end{tabular} & 105 & 85 & eixo B & 180 & 40 & \\
\hline & & & & & & eixo B2 & 180 & 75 & \\
\hline & & & S2 & 108 & 78 & Lm (Felds) & 195 & \begin{tabular}{|l|l|}
522 \\
\end{tabular} & \\
\hline & & & S2 & 95 & 66 & Lm (Felds) & 170 & 44 & \\
\hline & & & PA (D3) & 85 & 70 & eixo B & 170 & 49 & \\
\hline & & & \begin{tabular}{|l}
$\mathrm{PA}(\mathrm{D} 3)$ \\
\end{tabular} & 75 & 38 & & & & \\
\hline Paganzo & 6789257 & 528002 & so & 140 & 50 & & & & metarenitos vermelhos com Ms detrítica alternados por faixas metassiltíticas \\
\hline \multirow{5}{*}{ UM-523A } & \multirow{5}{*}{6785198} & \multirow{5}{*}{536628} & $\mathrm{~S} 2=\mathrm{S} 0$ & 230 & 64 & Le & 315 & 526 & \multirow{5}{*}{ metamargas acinzentadas com leitos amarronzados } \\
\hline & & & PA & 160 & 40 & & & & \\
\hline & & & PA & 100 & 44 & eixo B & 142 & 40 & \\
\hline & & & PA & 120 & 39 & $\mathrm{Lb}$ & 155 & 30 & \\
\hline & & & PA (dobras isoclinais) & 105 & 90 & eixo B & 10 & 13 & \\
\hline & & & S2 & 70 & 90 & eixo B & 148 & 6 & \\
\hline & & & S2 & 110 & 14 & & & & \\
\hline & & & S2 & 148 & 6 & & & & Grt-Qtz-Ep anfibolito verde, bandas e vênulas de material granítico vermelho sin foliação e \\
\hline UM-524 & $6 / 85487$ & $5364 / 8$ & S2 & 230 & 70 & & & & granitóide bco ambos grossos e camadas de até $20 \mathrm{~cm}$ de hornblendito grosso verde escuro \\
\hline & & & S2 & 235 & 65 & & & & \\
\hline & & & S2 & 220 & 70 & & & & \\
\hline
\end{tabular}




\begin{tabular}{|c|c|c|c|c|c|c|c|c|c|}
\hline \multirow{13}{*}{ UM-525 } & UTM-N & UTM-E & S-TIPO & S-DIR & S-DIP & L-TIPO & \begin{tabular}{ll|l} 
L-DIR & $L$ \\
\end{tabular} & L-DIP & \multirow{13}{*}{$\begin{array}{l}\text { Sequência calciossilicática: Grt-Ep-Bt-Plag-Qtz gnaisse cinza fino e sills boudinados/deformados } \\
\text { de anfibolito e granito }\end{array}$} \\
\hline & \multirow{12}{*}{6786277} & \multirow{12}{*}{535983} & S2 (charneira) & 95 & 35 & eixo B & 170 & 20 & \\
\hline & & & S2 (charneira) & 150 & 15 & eixo B & 168 & 15 & \\
\hline & & & S2 (charneira) & 220 & 22 & & & & \\
\hline & & & S2 (charneira) & 250 & 45 & $L b$ & 175 & 15 & \\
\hline & & & S2 (flanco) & 280 & 70 & & & & \\
\hline & & & S2 (flanco) & 95 & 90 & & & & \\
\hline & & & S2 (flanco) & 100 & 70 & & & . & \\
\hline & & & $\mathrm{S} 2$ & 260 & 65 & & & & \\
\hline & & & S2 & 263 & 65 & & & & \\
\hline & & & PA (D2?) & 160 & 17 & eixo B & 190 & 16 & \\
\hline & & & PA (D3?) & 240 & 70 & & & & \\
\hline & & & & & & eixo B & 175 & 9 & \\
\hline \multirow{8}{*}{ UM-526 } & \multirow{8}{*}{6786958} & \multirow{8}{*}{535658} & S2?=bandam/o (geral)??? & 245 & 70 & & & & \multirow{8}{*}{$\begin{array}{l}\text { Bt-Ep-Amph gnaisse bandado, granito róseo blastomilonito grosso e bandas/sills de anfibolito } \\
\text { grosso meso-melanocrático }\end{array}$} \\
\hline & & & & 55 & 65 & $\operatorname{Lm}$ (Felds) & 115 & 63 & \\
\hline & & & S2? & 72 & 75 & & & & \\
\hline & & & S2? & 20 & 73 & & & & \\
\hline & & & $\mathrm{PA}(\mathrm{D} 3)$ & 250 & 63 & eixo B (D3) & 340 & 18 & \\
\hline & & & & & & eixo B (D3) & 345 & 3 & \\
\hline & & & PA (D2) & 260 & 43 & eixo B (D2) & 305 & 16 & \\
\hline & & & PA (D2) & 330 & 25 & eixo B (D2) & 317 & 10 & \\
\hline \multirow{6}{*}{ UM-527 } & \multirow{6}{*}{6788410} & \multirow{6}{*}{533856} & $S 2$ & 280 & 75 & Lm (Amph) & 20 & 40 & \multirow{6}{*}{ gnaisses calciossilicáticos, anfibolito a Amph gnaisse pobre em Qtz e a Bt e Ep, cinza médio } \\
\hline & & & S2 & 278 & 65 & Lm (Chl) & 18 & 40 & \\
\hline & & & $S 2$ & 282 & 74 & & & & \\
\hline & & & $\mathrm{s} 2$ & 265 & & Le & 230 & 60 & \\
\hline & & & PA (D4?) & 145 & 48 & eixo B (D4?) & 175 & 46 & \\
\hline & & & PA & 200 & 55 & eixo B & 180 & 45 & \\
\hline \multirow{6}{*}{ UM-528 } & \multirow{6}{*}{6788363} & \multirow{6}{*}{533641} & bandamento gnaissico & 220 & 55 & Lm & 234 & 45 & \multirow{6}{*}{$\begin{array}{l}\text { intercala Ep-Hbl-Plag-Qtz gnaisse cinza porfiroblástico, Bt gnaisse cinza inequigranular médio e } \\
\text { boudins de metabásica }\end{array}$} \\
\hline & & & bandamento gnaissico & 265 & 55 & mullion & 185 & 60 & \\
\hline & & & Plano de falha normal & 150 & 65 & & & & \\
\hline & & & Plano de falha normal & 130 & 75 & & & & \\
\hline & & & $\mathrm{PA}(\mathrm{D} 3 ? !)$ & 250 & 63 & eixo B & 290 & 58 & \\
\hline & & & bandamento gnaissico & 250 & 53 & & & & \\
\hline \multirow{2}{*}{ UM-529 } & \multirow{2}{*}{6788788} & 532984 & bandamento gnaissico & 235 & 70 & $\mathrm{Lb}$ & 270 & 70 & $\mathrm{Hbl}$ gnaisse com bandas de $\mathrm{Hbl}-\mathrm{Bt}$ gnaisse e Bt gnaisse, tonalíticos cinza escuros \\
\hline & & & $\mathrm{PA}$ & 225 & 75 & eixo B & 215 & 48 & \\
\hline UM-530 & 6791034 & 531489 & $\begin{array}{l}\text { S2 } \\
\text { bandamento anaissico }\end{array}$ & \begin{tabular}{l|l}
325 \\
350
\end{tabular} & $\frac{45}{50}$ & $\mathrm{Lm}$ & 292 & 35 & Hbl-Bt granodiorito gnaisse cinza a cinza rosado lcal/e c/ Grt, e anfibolito com Grt \\
\hline & & & S2=S0 & $\frac{300}{40}$ & $\frac{50}{48}$ & Lm (Bt) & 20 & 45 & \\
\hline UM-531 & 6791045 & 530847 & S2 & 256 & & & $\frac{0}{15}$ & & com níveis de calciossilicáticas, Grt-Amph gnaisse calciossilicático médio cinza escuro \\
\hline & & & & 350 & 65 & Le & 320 & 60 & e granito gnaisse blastomilonítico \\
\hline & & & 52 & 110 & 80 & & & & \\
\hline & & & $\mathrm{S} 2$ & 315 & 18 & eixo B1 & 210 & 6 & \\
\hline & & & S2 (oblíqua) & 290 & 80 & & & & \\
\hline & & & S2 & 320 & 60 & $\mathrm{Lm}(\mathrm{Chl} / \mathrm{Bt})$ & 45 & 4 & \\
\hline & & & $\mathrm{S} 2$ & 312 & 55 & $\mathrm{Lm}(\mathrm{Chl} / \mathrm{Bt})$ & 235 & 15 & \\
\hline & & & S2 & 90 & 65 & Lm & 175 & 35 & Amph-Qtz-Chl xisto verde placoso, Grt-Chl-Ms-Bt xisto alternando c/ Grt-Chl-Bt-Ms-Qtz xisto \\
\hline UM-532 & 6792501 & 537089 & & 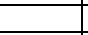 & & Lb (D1?) & 250 & 17 & cinza claros a prateados, Ms quartzito placoso mto fino em meio ao Chl-Amph xisto verde, \\
\hline & & & & & & Lb (posterior) & 105 & 65 & ortoquartzito-metachert e metabásica \\
\hline & & & S2 & 135 & 49 & $\mathrm{Lm}(\mathrm{Chl} / \mathrm{Bt})$ & 222 & 6 & \\
\hline & & & $\mathrm{PA}$ (cren) & 130 & 47 & Lb (cren) & 205 & 16 & \\
\hline & & & & & & eixo B & 210 & 6 & \\
\hline & & & S2 & 295 & 45 & Lm & 200 & 5 & \\
\hline & & & $\mathrm{s} 2$ & 275 & 65 & Lb & 25 & 43 & \\
\hline
\end{tabular}




\begin{tabular}{|c|c|c|c|c|c|c|c|c|}
\hline Pontos & UTM-N & UTM-E & S-TIPO & S-DIR & S-DIP & L-TIPO & \begin{tabular}{l|l|} 
L-DIR & L-DIP \\
\end{tabular} & Litotipos \\
\hline \multirow{7}{*}{ UM-533 } & \multirow{7}{*}{6807717} & \multirow{7}{*}{533750} & Smilon & 110 & 90 & Le & \begin{tabular}{ll|}
194 & 45 \\
\end{tabular} & \multirow{7}{*}{$\begin{array}{l}\text { Grt-Cpx anfibolito com níveis retroeclogíticos em boudins ricos em Grt-Cpx-Ep-Qtz, gnaisses } \\
\text { blatomilonítios a Bt e Bt-Amph gnaisse encaixantes }\end{array}$} \\
\hline & & & Smilon & 325 & 65 & $L \mathrm{Lm}$ & \begin{tabular}{|l|l|}
190 & 50 \\
\end{tabular} & \\
\hline & & & Bandamento & 120 & 90 & Lm (Felds) & \begin{tabular}{|l|l|}
205 & 22 \\
\end{tabular} & \\
\hline & & & Bandamento & 117 & 87 & Lm (Felds) & \begin{tabular}{|l|l|}
208 & 24 \\
\end{tabular} & \\
\hline & & & \begin{tabular}{|l|} 
Bandamento \\
\end{tabular} & 127 & 85 & Lm (Felds) & \begin{tabular}{|l|l|}
140 & 20 \\
\end{tabular} & \\
\hline & & & PA (c/ xistosi// PA - D2?) & 95 & 90 & eixo B & 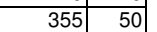 & \\
\hline & & & $\begin{array}{ll}\text { PA } \\
\end{array}$ & 300 & 70 & eixo B & \begin{tabular}{|l|l|}
200 & 23 \\
\end{tabular} & \\
\hline \multirow{11}{*}{ UM-534 } & \multirow{11}{*}{6801726} & \multirow{11}{*}{539051} & S2 & 270 & 72 & $\operatorname{Lm}(\mathrm{Ms})=\mathrm{Le}=\mathrm{Lb}$ & \begin{tabular}{l|l|}
195 & 35 \\
\end{tabular} & \multirow{11}{*}{$\begin{array}{c}\text { Bt-Ms-Qtz xisto cinza a cinza esverdeado c/ níveis de quartzito a } 2 \text { micas e pegmatito } \\
\text { protomilonítico }\end{array}$} \\
\hline & & & $\frac{P L}{P A}$ & 330 & 75 & eixo B & \begin{tabular}{|l|l|}
350 & 70 \\
\end{tabular} & \\
\hline & & & & & & Lmullion & \begin{tabular}{|l|l|}
240 & 70 \\
\end{tabular} & \\
\hline & & & S2 & 102 & 74 & Lm (Qtz) & \begin{tabular}{|l|l|}
347 & 65 \\
\end{tabular} & \\
\hline & & & & & & $\mathrm{Lb}=\mathrm{Lm}(\mathrm{Ms})$ & \begin{tabular}{|l|l|}
322 & 66 \\
\end{tabular} & \\
\hline & & & S2 & 270 & 63 & & & \\
\hline & & & $\mathrm{PA}$ & 300 & 73 & eixo B & \begin{tabular}{|l|l|}
230 & 55 \\
\end{tabular} & \\
\hline & & & & & & eixo B & \begin{tabular}{|l|l|}
200 & 35 \\
\end{tabular} & \\
\hline & & & S2 & 292 & 74 & Le & \begin{tabular}{l|l|}
283 & 65 \\
\end{tabular} & \\
\hline & & & S2 & 275 & 61 & & & \\
\hline & & & PA & 300 & 75 & eixo B & \begin{tabular}{|r|r|}
230 & 53
\end{tabular} & \\
\hline \multirow{3}{*}{ UM-535 } & \multirow{3}{*}{6801732} & \multirow{3}{*}{539394} & PA & 318 & 80 & $\operatorname{Lm}$ (Amph) & \begin{tabular}{l|l|}
290 & 70 \\
\end{tabular} & \multirow{3}{*}{ metagabro linear, verde leucocrático a Amph cortado por filöes pegmatíticos (PA) } \\
\hline & & & S2 & 270 & 60 & & 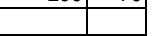 & \\
\hline & & & orientação pegmatito & 310 & 50 & & & \\
\hline \multirow{9}{*}{ UM-536 } & \multirow{9}{*}{6801990} & \multirow{9}{*}{539720} & S2 & 100 & 90 & & & \multirow{9}{*}{ metabásica e pegmatito mto grosso pouco deformado com Ms e Turm } \\
\hline & & & S2 & 265 & 45 & eixo B & \begin{tabular}{|l|l|}
333 & 25 \\
\end{tabular} & \\
\hline & & & $\frac{36}{S 2}$ & $\frac{2036}{256}$ & $\frac{40}{52}$ & Lm (Amph) & $\begin{array}{ll}0.02 \\
290 & 45 \\
\end{array}$ & \\
\hline & & & S2 & 285 & 37 & $\mathrm{Lm}$ & $300 \quad 34$ & \\
\hline & & & S2 & 260 & 85 & & $\begin{array}{lll} & -4 \\
\end{array}$ & \\
\hline & & & S2 & 270 & 30 & & & \\
\hline & & & S2 & 285 & 37 & Le & \begin{tabular}{|l|l|}
280 & 39 \\
\end{tabular} & \\
\hline & & & Clivagem (pegmatito) & 285 & 80 & eixo B & \begin{tabular}{ll|}
175 & 4 \\
\end{tabular} & \\
\hline & & & Clivagem (pegmatito) & 255 & 80 & eixo B & 265 & \\
\hline \multirow{4}{*}{ UM-537 } & \multirow{4}{*}{6801880} & \multirow{4}{*}{539912} & S1/S2 (S2 transposição) & 280 & 65 & $\mathrm{Lm}(\mathrm{Ms})=\mathrm{Lb} 2$ & \begin{tabular}{l|l|l}
315 & 55
\end{tabular} & \\
\hline & & & & & & Le & \begin{tabular}{|c|c|}
270 & 65 \\
\end{tabular} & Grt-Ms-Bt xisto rico em Qtz e com Plag (predominante), Ms-Bt quartzito cinza intercalados a Grt- \\
\hline & & & S2 transposição & 254 & 74 & Le & \begin{tabular}{|c|c|}
285 & 68 \\
\end{tabular} & Ms-Qtz xisto porfiroblástico, metabásicas subordinadas e pegmatitos \\
\hline & & & S2 transposição & 288 & 74 & Le & 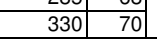 & \\
\hline & & & S2 2 & 270 & 65 & Le & $\begin{array}{ll}280 & 63 \\
280 & 3\end{array}$ & \\
\hline UM-538 & 6801917 & 540069 & PA (D2) & $\frac{285}{285}$ & 85 & eixo B (D2) & 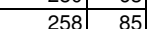 & mica xistos intercalados com metabásicas subordinadas cortados por diques pegmatitícos \\
\hline & & & S2 2 & 295 & 68 & $\mathrm{Lm}$ & \begin{tabular}{|c|c|c|c|}
250 & 73 \\
250
\end{tabular} & \\
\hline & & & S2 (dobrada) & 150 & 40 & & & \\
\hline & & & S2 (dobrada) & 195 & 33 & & & \\
\hline & & & S2 (dobrada) & 238 & 50 & & & \\
\hline & & & S2 (dobrada) & 255 & 60 & & & \\
\hline & & & S2 (dobrada) & 95 & 85 & & & \\
\hline & & & S2 (dobrada) & 85 & 68 & & & \\
\hline UM-539 & 6802188 & 540714 & S2 (dobrada) & 105 & 75 & & & mármore branco, bandado, ocorrem corpos grandes de pegmatitos e Grt-Ms-Bt-Qtz xisto com Ky \\
\hline & & & S2 (dobrada) & 270 & 78 & & & \\
\hline & & & S2 2 & 105 & 70 & & & \\
\hline & & & \begin{tabular}{|l|l|l|l} 
Falha inversa \\
\end{tabular} & 175 & 63 & & & \\
\hline & & & Clivagem (pegmatito) & 300 & 65 & & & \\
\hline & & & PA (D2?) & 110 & & eixo B (D2?) & \begin{tabular}{|l|l|}
20 & 14 \\
\end{tabular} & \\
\hline & & & $\overline{P A}$ & 105 & 65 & eixo B & \begin{tabular}{|l|l|}
185 & 30 \\
\end{tabular} & \\
\hline
\end{tabular}




\begin{tabular}{|c|c|c|c|c|c|c|c|c|c|}
\hline Pontos & UTM-N & UTM-E & S-TIPO & S-DIR & S-DIP & \begin{tabular}{|c|} 
L-TIPO \\
\end{tabular} & L-DIR & L-DIP & \multirow{27}{*}{$\begin{array}{l}\text { Amph-Bt gnaisse com Qtz e Plag bandado (gnaisses calciossilicáticos), ocorrem mármores } \\
\text { grossos beges no topo com frequentes boudins de metabásica e metabásica=anfibolito com } \\
\text { Amph tremolita/actnolita }\end{array}$} \\
\hline \multirow{26}{*}{ UM-540 } & \multirow{26}{*}{6798924} & \multirow{26}{*}{537190} & $\mathrm{~S} 2$ & 275 & 83 & L2/Le/eixo B (microdobras intrafoliais) & 185 & 20 & \\
\hline & & & & & & L2/Le/eixo B (microdobras intrafoliais) & 187 & 25 & \\
\hline & & & & & & L2/Le/eixo B (microdobras intrafoliais) & 185 & 15 & \\
\hline & & & & & & L2/Le/eixo B (microdobras intrafoliais) & 180 & 10 & \\
\hline & & & & & & Lm1 (Bt) & 355 & 28 & \\
\hline & & & & & & $\mathrm{Lm} 1(\mathrm{Bt})$ & 350 & 30 & \\
\hline & & & & & & L3 (microcren) & 225 & 70 & \\
\hline & & & $\mathrm{S} 2$ & 265 & & Le & 180 & 15 & \\
\hline & & & $\mathrm{S} 2$ & 270 & 65 & Le & 180 & 3 & \\
\hline & & & & & & Le & 170 & 12 & \\
\hline & & & & & & Le & 175 & 10 & \\
\hline & & & & & & Lb2 & 205 & \begin{tabular}{|c|}
62 \\
\end{tabular} & \\
\hline & & & & & & Lb2 & 15 & 25 & \\
\hline & & & S2 (banda/o) & 255 & 45 & Lm (Ep) & 190 & 20 & \\
\hline & & & & & & Lb (dobrado) & 208 & 45 & \\
\hline & & & & & & Lb (dobrado) & 235 & 65 & \\
\hline & & & & & & Lb (dobrado) & 320 & 50 & \\
\hline & & & & & & Lb (dobrado) & 285 & 73 & \\
\hline & & & & & & Lb (dobrado) & 193 & 30 & \\
\hline & & & & & & Lb (dobrado) & 198 & 35 & \\
\hline & & & & & & Lb (dobrado) & 265 & \begin{tabular}{|c|}
68 \\
\end{tabular} & \\
\hline & & & S2 & 260 & 85 & $\mathrm{Le}$ & 347 & $\begin{aligned} 8 \\
\end{aligned}$ & \\
\hline & & & & & & Lb2 & 170 & \begin{tabular}{|r|}
13 \\
\end{tabular} & \\
\hline & & & $\mathrm{S} 2$ & 255 & 69 & & & & \\
\hline & & & \begin{tabular}{|l|} 
S2 \\
\end{tabular} & 250 & 86 & Lb2 & 170 & 20 & \\
\hline & & & $\frac{O L}{P A}$ & $\frac{250}{280}$ & $\frac{60}{63}$ & & 110 & 20 & \\
\hline \multirow{21}{*}{ UM-541 } & \multirow{21}{*}{6798636} & \multirow{21}{*}{537950} & $\mathrm{~S} 2$ & 190 & 47 & Lm1 & 225 & 33 & \multirow{21}{*}{$\begin{array}{l}\text { olivina? gabro grosso a muito grosso e na base do gabro ocorre plagioclasio anfibolito linear de } \\
\text { granulacao media }\end{array}$} \\
\hline & & & S2 & 305 & 40 & Lm1 & 275 & \begin{tabular}{|l|}
35 \\
\end{tabular} & \\
\hline & & & $\mathrm{S} 2$ & 255 & 35 & Lm1 & 285 & 25 & \\
\hline & & & & & & Le & 205 & \begin{tabular}{|l|}
35 \\
\end{tabular} & \\
\hline & & & & & & eixo B & 225 & \begin{tabular}{|l|}
40 \\
40 \\
\end{tabular} & \\
\hline & & & Banda/o & 265 & 60 & Lmullion & 275 & \begin{tabular}{|l|}
60 \\
\end{tabular} & \\
\hline & & & & & & Le & 275 & 55 & \\
\hline & & & S2 & 18 & 60 & Lm1 & 350 & \begin{tabular}{|c|}
60 \\
\end{tabular} & \\
\hline & & & & & & Lm1 & 335 & \begin{tabular}{|c|}
55 \\
\end{tabular} & \\
\hline & & & & & & Lmullion & 290 & \begin{tabular}{|l|}
50 \\
\end{tabular} & \\
\hline & & & & & & \begin{tabular}{|l} 
Lmullion \\
\end{tabular} & $\frac{290}{275}$ & \begin{tabular}{|l|}
50 \\
50
\end{tabular} & \\
\hline & & & S2 & 250 & 55 & \begin{tabular}{|l|l|} 
Lm1 \\
\end{tabular} & $\frac{215}{315}$ & \begin{tabular}{|l|l|}
25 \\
\end{tabular} & \\
\hline & & & S2 & 240 & 33 & Lm (Felds) & 245 & \begin{tabular}{|l|}
20 \\
31
\end{tabular} & \\
\hline & & & $\mathrm{S} 2$ & 235 & 65 & Lm (Felds) & 292 & 40 & \\
\hline & & & $\mathrm{S} 2$ & 230 & 58 & Lm (Felds) & 290 & \begin{tabular}{|l|}
50 \\
\end{tabular} & \\
\hline & & & S2 & 293 & 47 & Le & 275 & \begin{tabular}{|r|}
43 \\
\end{tabular} & \\
\hline & & & \begin{tabular}{|l|} 
S2 \\
\end{tabular} & 295 & 68 & $L \mathrm{Lm} 1$ & 320 & \begin{tabular}{|l|}
65 \\
\end{tabular} & \\
\hline & & & S2 (geral) & 260 & 71 & & & & \\
\hline & & & PA & 205 & 65 & eixo B & 295 & \begin{tabular}{|l|}
41 \\
\end{tabular} & \\
\hline & & & $\mathrm{S} 2$ & 307 & 53 & Lm1 & 270 & 45 & \\
\hline & & & & & & Le (coronas) & 220 & \begin{tabular}{|l|}
10 \\
\end{tabular} & \\
\hline \multirow{7}{*}{ UM-542 } & & & Smilon & 280 & 85 & Le & 190 & 0 & \multirow{7}{*}{$\begin{array}{l}\text { St-Grt-Ky-Bt-Qtz (metagrauvaca microconglomeratica) milonito porfiroblastico porfiroclastico e } \\
\text { marmore conglomerático-brechado, margas bandadas }\end{array}$} \\
\hline & & & \begin{tabular}{|l|} 
Smilon \\
\end{tabular} & 140 & 20 & Le & 190 & \begin{tabular}{|r|}
15 \\
\end{tabular} & \\
\hline & & & Smilon & 100 & 82 & & & & \\
\hline & 6785453 & 521394 & Smilon & 100 & 75 & Le & 165 & 5 & \\
\hline & & & Smilon & 120 & 45 & & & & \\
\hline & & & PA (dobras isoclinais) & 115 & 68 & eixo B & 168 & 25 & \\
\hline & & & Smilon & 125 & 40 & Le & 170 & \begin{tabular}{|l|}
16 \\
\end{tabular} & \\
\hline
\end{tabular}




\begin{tabular}{|c|c|c|c|c|c|c|c|c|c|}
\hline Pontos & UTM-N & UTM-E & S-TIPO & S-DIR & S-DIP & L-TIPO & \begin{tabular}{ll|l} 
L-DIR & L \\
\end{tabular} & \begin{tabular}{|l|l|l|} 
L-DIP \\
\end{tabular} & \multirow{12}{*}{$\begin{array}{l}\text { granito grosso milonítico, cinza e ultramilonito cinza escuro porfiroclástico ambos com } \\
\text { portiroblastos de Grt, mármore brechado com seixos aleatórios }\end{array}$} \\
\hline \multirow{11}{*}{ UM-543 } & \multirow{11}{*}{6787454} & \multirow{11}{*}{521361} & Smilon & 150 & 45 & Le & 200 & 30 & \\
\hline & & & Smilon & 130 & 57 & Le & 120 & 54 & \\
\hline & & & Smilon & 130 & 60 & Le & 120 & 37 & \\
\hline & & & Smilon & 190 & 30 & Le & 20 & 23 & \\
\hline & & & Smilon & 170 & 35 & Le & 10 & 34 & \\
\hline & & & & & & Lb & 38 & 18 & \\
\hline & & & Smilon & 305 & 76 & Lm (Felds) & 220 & 28 & \\
\hline & & & Smilon & 318 & 86 & Lm (Felds) & 225 & 17 . & \\
\hline & & & Smilon & 220 & 21 & Le & 200 & 20 & \\
\hline & & & 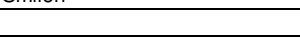 & ( & in & Lmullion & 210 & 16 & \\
\hline & & & & & & Lmullion & 200 & 20 & \\
\hline \multirow{7}{*}{ UM-544 } & \multirow{7}{*}{6799419} & \multirow{7}{*}{522833} & Fol (S2) & 298 & 77 & $\mathrm{Lm}$ & 205 & 5 & \multirow{7}{*}{$\begin{array}{l}\text { gnaisses calciossilicáticos bandados, bandas brancas a Plag, Qtz e carbonato e bandas verdes } \\
\text { claras a Amph, Ep e Chl. Bt frequente e intercalaçôes de Ms-Bt quartzito equigranular fino }\end{array}$} \\
\hline & & & Fol (S2) & 277 & 70 & Le & 10 & 20 & \\
\hline & & & & & & $\mathrm{Lb}$ & 10 & 31 & \\
\hline & & & & 120 & 73 & Lm (Amph) & 30 & 23 & \\
\hline & & & & 130 & 63 & & & & \\
\hline & & & PA & 110 & 63 & eixo B & 35 & 18 & \\
\hline & & & $\mathrm{PA}$ (D2) & 302 & 62 & eixo B (D2) & 20 & 27 & \\
\hline \multirow{5}{*}{ UM-545 } & \multirow{5}{*}{6799407} & \multirow{5}{*}{522879} & Banda $/ \mathrm{o}=\mathrm{S} 2$ & 120 & 90 & Lm & 25 & 8 & \multirow{5}{*}{$\begin{array}{l}\text { filão de Bt granito leuco a hololeucocrático porfirítico intrudindo gnaisses calciossilicáticos e } \\
\text { faixas locais cataclásticas a protomiloníticas no Bt granito }\end{array}$} \\
\hline & & & & & $t$ & Lmullion=L2 & 205 & $\begin{array}{r}3 \\
\end{array}$ & \\
\hline & & & Smilon & $\frac{282}{215}$ & 75 & Le & 355 & 17 & \\
\hline & & & Cliv Protomilon & 115 & 85 & & & & \\
\hline & & & Diáclase & \begin{tabular}{l|l}
95 \\
\end{tabular} & 58 & LFK (fluxo) & 25 & 25 & \\
\hline \multirow{6}{*}{ UM-546 } & \multirow{6}{*}{6799253} & \multirow{6}{*}{523051} & Sn & 100 & 76 & & & & \multirow{6}{*}{$\begin{array}{l}\text { Bt granito porfirítico rosa avermelhado de granulação média, hipidiomórfico com fenocristais } \\
\text { idiomórficos de } \mathrm{FK} \text { de até } 2 \mathrm{~cm} \text {. Possui enclaves máficos ricos em Bt }\end{array}$} \\
\hline & & & $S n+1$ & 136 & 79 & & & & \\
\hline & & & Cliv & 145 & 90 & & & & \\
\hline & & & Diáclase & 20 & 55 & & & & \\
\hline & & & Diáclase & 110 & 40 & & & & \\
\hline & & & Diáclase & 200 & 30 & & & & \\
\hline & & & Cliv ardosiana (mega xenólito) & 265 & 70 & & & & \\
\hline & & & Cliv ardosiana (mega xenólito) & 292 & 70 & & & & \\
\hline & & & Cliv (no granito) & 275 & 85 & & & & \\
\hline & & & PA (no xenólito) & 285 & 58 & eixo B & 240 & 48 & \\
\hline & & & PA D3 (no xenólito) & 245 & 50 & eixo B & 295 & 35 & \\
\hline & & & & 265 & 73 & & & & Bt granito com diversos xenólitos, xenólitos de ardósia (ou metabásica fina), metassiltito-arenito, \\
\hline UM-547 & 6799109 & 523229 & Sn & 285 & 45 & $\mathrm{Lb}$ & 122 & 22 & Ms quartzito com bandas de ortoquartzito e Bt-Qtz xisto fino, com Grt, níveis de xistos mais \\
\hline & & & $\mathrm{Sn+1}$ & 295 & 63 & & & & micáceos ocorrem Ky e bandas de sillimanita fibrosa e ocorre Bt pegmatito rosado, dobrado e \\
\hline & & & S2 & 270 & 76 & & & & transposto em zona de transposição D3. Relações D2-D3 \\
\hline & & & $\mathrm{Sn+1}$ & 335 & 80 & & & & \\
\hline & & & dique & $\frac{5030}{230}$ & 43 & & & & \\
\hline & & & $S n+1$ & 280 & 84 & & & & \\
\hline & & & S2 (no xenólito) & 275 & 55 & Lb & 285 & 55 & \\
\hline & & & Diáclase & 215 & 25 & & & & \\
\hline & & & Sn & 265 & 63 & & & & \\
\hline UM-548 & 6798863 & 523361 & $\mathrm{Sn+1}$ & 290 & 74 & & & 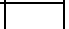 & granito porfirítico com enclaves máficos \\
\hline & & & Sn & 260 & 65 & & & & \\
\hline & & & Falha & 260 & 82 & & & & \\
\hline & & & Fol Protomilon & 295 & 80 & & & & \\
\hline & & & Fol Protomilon & 295 & 85 & Le & 30 & 15 & \\
\hline & & & Fol Protomilon & 260 & 75 & & & & \\
\hline & & & Fol Protomilon & 270 & 70 & & & & \\
\hline UM-549 & 6798791 & 523156 & Fol Protomilon & 295 & 80 & & & & granito protomilonítico, porfiroclástico com xenólitos de rocha metabásica com dobras \\
\hline (1) & ו & & Fol Protomilon & 300 & 66 & Lm (Felds) & 22 & 18 & assimétricas (D3). São faixas protomiloníticas no granito! \\
\hline & & & Fol Protomilon & 290 & 55 & $\operatorname{Lm}(\mathrm{Qtz})$ & 352 & 34 & \\
\hline & & & Fol Protomilon & 270 & 55 & & & 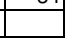 & \\
\hline & & & Fol Protomilon & 275 & 70 & & & & \\
\hline
\end{tabular}




\begin{tabular}{|c|c|c|c|c|c|c|c|c|c|}
\hline Pontos & UTM-N & UTM-E & S-TIPO & S-DIR & S-DIP & L-TIPO & L-DIR $\mathrm{L}$ & L-DIP & Litotipos \\
\hline \multirow{5}{*}{ UM-550 } & \multirow{5}{*}{6798816} & \multirow{5}{*}{523063} & Fol Protomilon & 305 & 70 & & & & \multirow{5}{*}{ granito com faixas protomiloníticas e xenólito de rocha metassedimentar } \\
\hline & & & Fol Protomilon & 282 & $65 \mathrm{~L}$ & Lm (Felds) & 3 & 30 & \\
\hline & & & Fol Protomilon & 290 & 65 & & 35 & 5 & \\
\hline & & & Fol Protomilon & 295 & $52 \mathrm{~L}$ & Lb & 35 & 6 & \\
\hline & & & Fol Protomilon & 288 & 68 & & & & \\
\hline \multirow{7}{*}{ UM-551 } & \multirow{7}{*}{6798734} & \multirow{7}{*}{522932} & Fol & 300 & $80 \mathrm{~L}$ & Lmullion & 210 & 40 & \multirow{7}{*}{ Bt granito grosso, localmente cloritizado com xenólitos de metagrauvaca } \\
\hline & & & Fol & 305 & & & 358 & 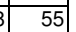 & \\
\hline & & & Fol & 285 & $65 \mathrm{~L}$ & Lm (Plag) & 0 & $\frac{3}{15}$ & \\
\hline & & & Falha & 130 & $80 \mathrm{~L}$ & Le (Felds roxo) & 142 & 87 & \\
\hline & & & PA & 282 & 67 & eixo B & 355 & \begin{tabular}{|c|}
5 \\
\end{tabular} & \\
\hline & & & Xistosidade PA (granito) & 285 & 80 & eixo B & 190 & 10 & \\
\hline & & & Xistosidade (xisto) & 270 & 60 & & & & \\
\hline \multirow{3}{*}{ UM-552 } & \multirow{3}{*}{6798611} & \multirow{3}{*}{522853} & Fol (metagrauvaca) & 280 & 50 & & & & \multirow{3}{*}{ granito protomilonitizado com xenólitos de metagrauvaca } \\
\hline & & & Fol Protomilon & 282 & 63 & & & & \\
\hline & & & Fol Protomilon & 304 & $70 \mathrm{~L}$ & $\operatorname{Lm}(\mathrm{Chl})$ & 350 & 65 & \\
\hline \multirow{9}{*}{ UM-553 } & \multirow{9}{*}{6798649} & \multirow{9}{*}{522723} & Fol (bandamento) & 230 & $50 \mathrm{~L}$ & $\mathrm{Lm}$ & 180 & 50 & \multirow{9}{*}{$\begin{array}{l}\text { sequencias de rochas calciossilicáticas e granito milonítico. Provável contato entre granito e } \\
\text { calciossilicáticas - zona de cisalhamento }\end{array}$} \\
\hline & & & Fol (bandamento) & 235 & $55 \mathrm{~L}$ & Lm & 205 & 50 & \\
\hline & & & Smilon & 250 & $65 \mathrm{~L}$ & Le & 170 & 40 & \\
\hline & & & Smilon & 245 & $64 \mathrm{~L}$ & Le & 178 & \begin{tabular}{|r|r|}
3 & 32 \\
\end{tabular} & \\
\hline & & & Fol & 245 & 70 & & 110 & & \\
\hline & & & Falha dextral & 130 & 75 & & & & \\
\hline & & & Fol (geral) & 245 & 53 & & & & \\
\hline & & & Smilon & 252 & 53 & & & & \\
\hline & & & Smilon & 290 & 60 & & & & \\
\hline \multirow{17}{*}{ UM-554 } & \multirow{17}{*}{6798599} & \multirow{17}{*}{522651} & S2 (metagrauvaca) & 215 & 60 & & & & \multirow{17}{*}{ metagrauvaca conglomerática, metamargas e milonitos graníticos } \\
\hline & & & PA & 250 & 60 & eixo $B$ & 240 & 60 & \\
\hline & & & Smilon (amostra B) & 200 & 60 & & & & \\
\hline & & & Smilon (amostra A) & 285 & $80 \mathrm{~L}$ & Le & 200 & 35 & \\
\hline & & & S2 (metagrauvaca) & 330 & & L2 & 248 & $3 \quad 35$ & \\
\hline & & & S2 (calciossilicática) & 270 & 52 & & & & \\
\hline & & & S2 (atitude geral) & 265 & 60 & & & & \\
\hline & & & S2 2 & 280 & & Le & 338 & 20 & \\
\hline & & & PA & 230 & 55 & eixo B & 240 & 65 & \\
\hline & & & PA & 280 & 40 & & & & \\
\hline & & & PA & 255 & 74 & & 355 & \begin{tabular}{|r|}
5 \\
5
\end{tabular} & \\
\hline & & & & & & Lmullion & 345 & 5 & \\
\hline & & & PA & 275 & 43 & & & & \\
\hline & & & $\mathrm{PA}$ & 280 & & eixo B & 320 & 4 & \\
\hline & & & PA & 275 & 33 & eixo $B$ & 340 & \begin{tabular}{|r|} 
\\
\end{tabular} & \\
\hline & & & $\mathrm{PA}$ & 255 & 80 & eixo B & 0 & 5 & \\
\hline & & & S2 (metagrauvaca) & 350 & $85 \mathrm{~L}$ & L2=Le & 245 & \begin{tabular}{|r|}
53 \\
\end{tabular} & \\
\hline UM-601 & 6770415 & 527349 & & & & & & & ndentes de grauvace \\
\hline
\end{tabular}




\begin{tabular}{|c|c|c|c|c|c|c|c|c|c|}
\hline $\begin{array}{l}\text { Pontos } \\
\end{array}$ & UTM-N & UTM-E & S-TIPO & S-DIR & S-DIP & L-TIPO & L-DIR & L-DIP & \multirow{16}{*}{$\begin{array}{l}\text { milonitos escuros com bandas félsicas protomiloníticas rosadas a esbranquiçadas de granulação } \\
\text { grossa e ocorrem boudins máficos associados à dobras fechadas }\end{array}$} \\
\hline \multirow{15}{*}{ UM-602 } & \multirow{15}{*}{6786744} & \multirow{15}{*}{521369} & Smilon & 105 & 58 & Le & 54 & 46 & \\
\hline & & & Smilon & 116 & 52 & $\operatorname{Lm}(\mathrm{Grt})$ & 52 & 30 & \\
\hline & & & Smilon & 108 & 42 & $\operatorname{Lm}(\mathrm{Ky})$ & 89 & 40 & \\
\hline & & & Smilon & 95 & 45 & Le & 110 & 50 & \\
\hline & & & Smion & 115 & 35 & Le & 115 & 35 & \\
\hline & & & Smilon & 105 & & Le & 58 & 50 & \\
\hline & & & Smilon & 120 & 59 & Lb (cren) & 152 & 60 & \\
\hline & & & Smilon & 118 & 30 & Lb (cren) & 150 & 25 & \\
\hline & & & Smilon & 110 & 46 & $\mathrm{Le}$ & 108 & 41 & \\
\hline & & & Smilon & 102 & 44 & $\mathrm{Le}$ & 118 & 38 & \\
\hline & & & Smilon & 105 & 43 & Le & 108 & 43 & \\
\hline & & & dique & 340 & 60 & & & & \\
\hline & & & dique & 345 & 65 & & & & \\
\hline & & & dique & 350 & 69 & & & & \\
\hline & & & & & & eixo B (dobra sinfolial) & 80 & 35 & \\
\hline \multirow{11}{*}{ UM-603 } & \multirow{11}{*}{6787731} & \multirow{11}{*}{521231} & Smilon & 200 & 41 & Lm (Plag) & 212 & 40 & \multirow{17}{*}{$\begin{array}{l}\text { milonitos escuros com porfiroblastos e porfiroclastos estirados (sigmoidais-lenticulares), } \\
\text { intercalam bandas descontínuas félsicas (graníticas) e bandas boudinadas a contínuas tabulares } \\
\text { de Grt anfibolito e ocorre mármore branco de aspecto brechóide em camadas lenticulares com } \\
\text { fragmentos angulosos a arredondados de milonito }\end{array}$} \\
\hline & & & Smilon & 173 & 55 & Le & 213 & 45 & \\
\hline & & & Smilon & 199 & 42 & Lm (Plag) & 190 & 40 & \\
\hline & & & Smilon & 150 & 45 & $\mathrm{Le}=\mathrm{Lm}$ (Amph) & 205 & 35 & \\
\hline & & & Smilon & 132 & $\frac{43}{40}$ & Le & $\frac{200}{200}$ & $\frac{00}{15}$ & \\
\hline & & & Smilon & 115 & 35 & Le & 150 & 25 & \\
\hline & & & Smilon & 200 & 43 & Le & 215 & 38 & \\
\hline & & & Smilon & 210 & 36 & Le & 218 & 36 & \\
\hline & & & Smilon & 135 & 42 & Le & 220 & 21 & \\
\hline & & & $\mathrm{S} 2=\mathrm{S} 0$ & 155 & 65 & Le & 125 & 60 & \\
\hline & & & faixa cataclástica & 160 & 40 & & & & \\
\hline \multirow{6}{*}{ UM-603A } & \multirow{6}{*}{6787500} & \multirow{6}{*}{521356} & Smilon & 175 & 28 & Le & 155 & 28 & \\
\hline & & & Smilon & 160 & 30 & Le & 150 & 30 & \\
\hline & & & Smilon & 155 & 25 & Lb (dobra intrafolial) & 203 & 15 & \\
\hline & & & Smilon & 155 & 30 & & 170 & 30 & \\
\hline & & & Smilon & 137 & 29 & & 165 & $\frac{04}{22}$ & \\
\hline & & & Smilon & 163 & 20 & & 180 & 18 & \\
\hline \multirow{9}{*}{ UM-604 } & \multirow{9}{*}{6788292} & \multirow{9}{*}{521679} & Smilon & 188 & 40 & & & & \multirow{9}{*}{$\begin{array}{l}\text { milonitos escuros com bandas félsicas, bandas granatíferas e bandas finamente foliada. } \\
\text { intercalam níveis de mármores brechóides e bandas anfibolíticas, e ocorre dique de rocha } \\
\text { esverdeada maciça (basalto...) }\end{array}$} \\
\hline & & & Smilon (mármore) & 202 & 46 & & & & \\
\hline & & & dique & 290 & 67 & & & & \\
\hline & & & Smilon & 187 & 58 & Lb (cren) & 240 & 40 & \\
\hline & & & Smilon & 184 & 31 & Le & $\frac{270}{260}$ & 14 & \\
\hline & & & Smilon & 230 & 22 & $\mathrm{Le}$ & 250 & 18 & \\
\hline & & & Smilon & 188 & 30 & Le & 255 & 16 & \\
\hline & & & dique & 275 & 75 & & & & \\
\hline & & & Smilon & 185 & 45 & Le & 268 & 15 & \\
\hline \multirow{9}{*}{ UM-605 } & & & so & 271 & 55 & & & & \multirow{9}{*}{$\begin{array}{l}\text { intercalaçōes métricas de arenitos arcoseanos cinza, arenitos conglomeráticos, conglomerados e } \\
\text { argilitos-siltitos escuros }\end{array}$} \\
\hline & & & So & 255 & 52 & & & & \\
\hline & & & so & 290 & 50 & & & & \\
\hline & & & Cliv & 78 & 57 & Lint (S0-Cliv) & 225 & 25 . & \\
\hline & 6798925 & 521016 & So & 260 & 65 & & & & \\
\hline & & & So & 265 & 58 & & & & \\
\hline & & & so & 260 & 63 & & & & \\
\hline & & & Cliv & 118 & 49 & & & & \\
\hline & & & Cliv & 75 & 40 & Lint (S0-Cliv) & 355 & 5 & \\
\hline
\end{tabular}




\begin{tabular}{|c|c|c|c|c|c|c|c|c|c|}
\hline Pontos & UTM-N & UTM-E & S-TIPO & S-DIR & S-DIP & L-TIPO & L-DIR & \begin{tabular}{|l|l|l|} 
L-DIP \\
\end{tabular} & Litotipos \\
\hline \multirow{8}{*}{ UM-606 } & \multirow{8}{*}{6799050} & \multirow{8}{*}{520822} & Plano de falha & 115 & 77 & estrias & 42 & 58 & \multirow{8}{*}{$\begin{array}{l}\text { arenito verde de granulação média, ocorrem veios carbonáticos preenchendo fraturas e espesso } \\
\text { (1,5 } \mathrm{m} \text { de espessura) de veio de Qtz e há diques de diabásio e subvulcânica félsica }\end{array}$} \\
\hline & & & Plano de falha & 120 & 81 & estrias & 80 & 71 & \\
\hline & & & So & 175 & 65 & & & & \\
\hline & & & So & 170 & 55 & & & & \\
\hline & & & So & 165 & 69 & & & & \\
\hline & & & veio de Qtz & 225 & 56 & & & & \\
\hline & & & dique & 60 & 70 & & & & \\
\hline & & & dique & 50 & 35 & & & & \\
\hline \multirow{2}{*}{ UM-607 } & \multirow{2}{*}{6798773} & \multirow{2}{*}{521364} & So & 104 & 30 & & & & \multirow{2}{*}{$\begin{array}{c}\text { arenito arcoseano, lítico com intercalaçōes de arenitos conglomeráticos cinza esverdeado e } \\
\text { conglomerados polimíticos }\end{array}$} \\
\hline & & & Fratura intensa ou Cliv & 210 & 40 & & & & \\
\hline \multirow{10}{*}{ UM-608 } & \multirow{10}{*}{6785714} & \multirow{10}{*}{521280} & \begin{tabular}{|l|l|} 
Smilon \\
\end{tabular} & 120 & 63 & & & & \multirow{10}{*}{$\begin{array}{l}\text { no topo ocorrem Ky-Grt-mica-Qtz xisto fino com Plag e St??, porfiroblástico e bandas de granito } \\
\text { rosa avermelhado protomilonítico, há níveis mais quartźticos e na base ocorrem gnaisses } \\
\text { miloníticos a Grt, bandas anfibolíticas }\end{array}$} \\
\hline & & & Cliv cren & 55 & 90 & & & & \\
\hline & & & Cliv cren & 323 & 35 & Lb & 43 & 13 & \\
\hline & & & Cliv & 15 & 59 & & & & \\
\hline & & & Smilon & 125 & 30 & & & & \\
\hline & & & Smilon & 132 & 32 & Lb (cren) & 57 & 9 & \\
\hline & & & Smilon & 122 & 45 & Le & 167 & 38 & \\
\hline & & & Smilon & 115 & 45 & Le & 130 & 45 & \\
\hline & & & Smilon & 110 & 46 & Le & 135 & 48 & \\
\hline & & & Smilon & 107 & 70 & Le & 175 & 45 & \\
\hline \multirow{6}{*}{ UM-609 } & \multirow{6}{*}{6799599} & & Fol & 295 & 86 & Le (Felds) & 25 & \begin{tabular}{|l|}
23 \\
21
\end{tabular} & \multirow{7}{*}{$\begin{array}{c}\text { metagabros a anfibolitos bandados, com bandas máficas e bandas félsicas, ocorrem apófises de } \\
\text { granito porfirítico intrudindo a sequência metamóórica e há rocha fésisca finamente foliada com } \\
\text { porfiroclastos de Qtz-Felds (FK) - milonito granítico? }\end{array}$} \\
\hline & & & $\begin{array}{l}\text { Fol } \\
\text { Fol }\end{array}$ & 108 & 77 & Le & 22 & 21 & \\
\hline & & & $\begin{array}{l}\text { Fol } \\
\text { dique (anófise) }\end{array}$ & \begin{tabular}{l|l|}
104 \\
156
\end{tabular} & 72 & & & & \\
\hline & & $522 / / 4$ & $\begin{array}{l}\text { dique (apotise) } \\
\text { Plano de fallha }\end{array}$ & 156 & 43 & & & & \\
\hline & & & & 188 & 20 & estrias & 133 & 18 . & \\
\hline & & & & 275 & 76 & Le & 355 & 32 & \\
\hline & & & Fol & 120 & 85 & Le & 30 & 20 & \\
\hline UM-609A & 6799638 & 522961 & Fol & 282 & 59 & Le & 350 & 26 & granito roxo porfirítico deformado \\
\hline \multirow{5}{*}{ UM-610 } & & & Fol (enclave) & 275 & 75 & & & & \\
\hline & & & Fol (granito) & 122 & 77 & Le & 60 & 63 & \\
\hline & 6801049 & 524508 & Fol (granito) & 196 & 90 & Le & 60 & 65 & granito inequigranular grosso rosado com enclaves maficos paralelos a foliação metamórfica \\
\hline & & & Fol (enclave) & 135 & 90 & Le (Felds) & 225 & 0 & \\
\hline & & & & & & Le (Felds) & 42 & 10 & \\
\hline & & & Fol & 106 & 63 & $\mathrm{Lm}(\mathrm{Hbl})$ & 146 & 55 & \\
\hline & & & Fol & 105 & 66 & $\mathrm{Lm}(\mathrm{Hbl})$ & 172 & 46 & \\
\hline & & & Fol & 125 & 53 & (im & $11<$ & +40 & \\
\hline & & & Fol & 180 & 69 & $\operatorname{Lm}($ Amph) & 210 & 66 & Bt gnaisse e Bt-Hbl gnaisse com intercalações de anfibolitos, ocorrem diques e corpos \\
\hline UM-611 & 6801187 & 524950 & Fol (milon) & 110 & 43 & & & & pegmatóides cortando a seq gnaissica e há espelho de falha (rúptil) associado à veios \\
\hline & & & Fol (milon) & 120 & 39 & Le & 175 & 42 & epidotíticos \\
\hline & & & PA & 200 & 63 & eixo B & 145 & 57 & \\
\hline & & & PA & 203 & 73 & eixo B & 125 & 58 & \\
\hline & & & Fol (S2) & 130 & 55 & Lb2 & 170 & 48 & \\
\hline UM-612 & 6801207 & 525005 & Fol & 110 & 35 & Le & 147 & 31 & Hbl-Bt gnaisse, gnaisse muscovítico e corpo pegmatítico intrusivo \\
\hline & & & Fol & 50 & 34 & & & & \\
\hline $4 M-612$ & 6801214 & 525087 & & & & & & & seq. gnaissica com níveis de Grt anfibolito e camadas de xisto esverdeado, há dique de rocha \\
\hline UM-613 & 6801214 & 52508 & & & & & & & básica intrudindo a seq. \\
\hline & & & & & & & & & \\
\hline & & & Fol & 87 & 15 & $\mathrm{Lb}$ & 54 & 32 & \\
\hline & & & Fol & 330 & 75 & Lb & 75 & 40 & \\
\hline & & & Fol & 105 & 25 & Le & 185 & 2 & \\
\hline & & & Fol & 90 & 30 & Lb & 20 & 10 & seq. de quartzitos impuros micáceos placosos com intercalaçôes de anfibolito e Grt pegmatito \\
\hline UM-614 & 6801297 & 538495 & orientação pegmatito & 60 & 60 & & + & & (leucopegmatito), veios pegmatíticos com Grt ocorrem paralelos à Fol e deformados, e há \\
\hline & & & & 270 & 85 & $\mathrm{Lb}$ & 354 & 40 & \\
\hline & & & Fol & 264 & 36 & Lb2 & 342 & 14 & \\
\hline & & & Fol & 270 & 40 & LintD2 (Bt) & 330 & 25 & \\
\hline
\end{tabular}




\begin{tabular}{|c|c|c|c|c|c|c|c|c|c|}
\hline Pontos & UTM-N & UTM-E & S-TIPO & S-DIR & S-DIP & L-TIPO & \begin{tabular}{|l|l} 
L-DIR & L \\
\end{tabular} & L-DIP & \multirow{7}{*}{$\begin{array}{l}\text { seq. de Ms-Qtz xisto intercalado com anfibolitos quartzosos, mármores escuros e xistos } \\
\text { quartzosos }\end{array}$} \\
\hline \multirow{6}{*}{ UM-615 } & & & Fol & 298 & 74 & $\operatorname{Lm}(\mathrm{Ms})$ & 8 & 30 & \\
\hline & & & & & & mullion Qtz & 198 & 5 & \\
\hline & & & plano de falha & 290 & 54 & estria & 220 & 28 & \\
\hline & 6800981 & 538658 & Fol & 288 & 63 & Lm (Ms) & 360 & 33 & \\
\hline & & & Fol & 280 & 65 & Lm (Qtz) & \begin{tabular}{l|}
360 \\
345
\end{tabular} & \begin{tabular}{|r|}
25 \\
28 \\
\end{tabular} & \\
\hline & & & Fol & 272 & 66 & & & & \\
\hline \multirow{6}{*}{ UM-616 } & & & Fol & 118 & 68 & & & & \multirow{6}{*}{$\begin{array}{l}\text { Ky-Ms-Chl xisto c/ Grt e PI (Ky ou albita??) com intercalações subordinadas de quartzito fino, há } \\
\text { injeçōos graníticas, de granito tipo guandacolinos deformado no estado semi-sólido, rico em } \\
\text { xenólitos e carbonatos brechados com fragmentos de anfibolitos e de metassedimentos }\end{array}$} \\
\hline & & & \begin{tabular}{|l|l|} 
Fol \\
\end{tabular} & 130 & 84 & \begin{tabular}{|l|}
$\mathrm{Le}$ \\
\end{tabular} & 225 & 17. & \\
\hline & & & Fol & 320 & 80 & Lm (Chl) & 28 & 55 & \\
\hline & 6811501 & $5316 / 9$ & Fol & 310 & 85 & & & & \\
\hline & & & Fol & 295 & 80 & $\mathrm{Le}$ & 25 & 10 & \\
\hline & & & Fol & 217 & 85 & $\mathrm{Le}$ & 43 & 35 & \\
\hline \multirow{2}{*}{ UM-617 } & & & Fol & 135 & 65 & $\operatorname{Lm}(\mathrm{Bt})$ & 210 & 65 & \multirow{2}{*}{$\begin{array}{c}\text { ortognaisse bandado com bandas brancas e bandas de granito milonítico porfiroclástico rosa. } \\
\text { Ocorrem anfibolitos e Grt anfibolitos }\end{array}$} \\
\hline & 6810269 & 534288 & Fol & 140 & 73 & Le & 150 & 73 & \\
\hline \multirow{3}{*}{ UM-618 } & & & Fol & 154 & 40 & $\operatorname{Lm}(\mathrm{St})$ & 140 & 35 & \multirow{3}{*}{$\begin{array}{l}\text { St-Bt-Chl-Ms xisto compegmatito foliado a Ms. Ocorrem diques de diabásio dobrado concordante } \\
\text { à foliação }\end{array}$} \\
\hline & 6800756 & 538725 & & & & Lb & 225 & 18 & \\
\hline & & & $\begin{array}{l}\text { dique } \\
\text { rol }\end{array}$ & $\frac{165}{250}$ & \begin{tabular}{l|l}
49 \\
63 \\
\end{tabular} & & & & \\
\hline \multirow{4}{*}{ UM-619 } & & & Fol & 275 & 85 & & & 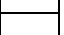 & \multirow{4}{*}{$\begin{array}{l}\text { espesso pacote de calciarenito bege a branco com esparsos fragmentos de rocha metabásica } \\
\text { fina e quartzito placoso intercalam-se em Ms-carbonato-Qtz filito }\end{array}$} \\
\hline & 6800078 & 538492 & Fol & 275 & 65 & & & & \\
\hline & & & Fol & 270 & 75 & $\mathrm{Lm}=\mathrm{L} 2$ & 330 & 50 & \\
\hline & & & & & & Lb2 & 340 & 25 & \\
\hline \multirow{5}{*}{ UM-620 } & & & Fol & 262 & 80 & Lm & 175 & 20 & \multirow{5}{*}{ embasamento?? } \\
\hline & & & Fol & 270 & 76 & Lm & \begin{tabular}{l|l|}
178 \\
\end{tabular} & 18 & \\
\hline & 6798925 & 537070 & Fol & 280 & 60 & Lm & 185 & 9 & \\
\hline & & & Fol & 225 & 65 & eixo B & 200 & 50 & \\
\hline & & & Fol & 240 & 71 & Le & \begin{tabular}{l|l|}
155 \\
\end{tabular} & 15 & \\
\hline \multirow{5}{*}{ UM-621 } & & & Fol & 90 & 90 & Lb2 & 185 & 20 & \multirow{5}{*}{$\begin{array}{l}\text { Ep-Bt-Qtz-Amph xisto cinza maciço contendo bandas subcentim de Qtz+Pl, camada de cerca de } \\
20 \mathrm{~m} \text { de espessura de Bt-Amph xisto contendo corpos de metabásicas e carbonatos impuro e } \\
\text { bandas de gnaisse throndjemítico cinza claro }\end{array}$} \\
\hline & & & Fol & 95 & 70 & Lb2 & \begin{tabular}{|l|l|}
185 \\
\end{tabular} & 0 & \\
\hline & 6799085 & 537121 & Fol & 185 & 10 & $\operatorname{Lm}(\mathrm{Bt})$ & \begin{tabular}{l|l|}
175 \\
\end{tabular} & 10 & \\
\hline & & & Fol & 255 & 63 & & & & \\
\hline & & & Fol & 263 & 50 & Lb2 & 178 & 8 & \\
\hline \multirow{7}{*}{ UM-622 } & & & Fol & 309 & 49 & Le (coronas) & 33 & 4 & \multirow{7}{*}{$\begin{array}{l}\text { Ms-Bt-Qtz xisto com lâminas de Ms quartzito, ambos com Pl, intercala-se provável metamarga a } \\
\text { Bt, com Ms, Pl, Ep e carbonato?, em contato tectonicamente paralelo ocorre metagabro } \\
\text { coronítico, local/e bandado }\end{array}$} \\
\hline & & & Fol & 315 & 69 & Le (coronas) & 28 & 5 & \\
\hline & & & Fol & 290 & 45 & $\begin{array}{l}\text { Le (coronas) } \\
\end{array}$ & 0 & 10 & \\
\hline & 6799016 & 537765 & \begin{tabular}{|l|l|} 
Fol \\
\end{tabular} & 300 & 70 & $\mathrm{Le}$ & 13 & 15 & \\
\hline & & & Fol & 305 & 69 & & & & \\
\hline & & & Fol & 280 & 69 & $\begin{array}{llll}\mathrm{Le} & & & \\
\end{array}$ & 265 & 60 & \\
\hline & & & Fol & 290 & 52 & Le & 170 & 25 & \\
\hline \multirow{3}{*}{ UM-623 } & & & Fol & 255 & 58 & Le (coronas) & 260 & 51 & \\
\hline & 6798670 & 537734 & Fol & 230 & 70 & & & & seq de quartzito carbonático placoso, pegmatitos protomilonitícos a Bt na Fol e metagabro \\
\hline & & & Xistosi// oblíqua & 160 & 30 & Lint (Fol//xist obl) & 230 & 45 & \\
\hline & & & Fol & 285 & 25 & Le & 355 & 8 & \\
\hline UM-624 & 6798041 & 535746 & Fol & 275 & 60 & eixo B (dobras monoclinais) & 5 & 10 & concordantes à fol, protomilonitizados e no topo ocorrem anfibolitos com Grt \\
\hline & & & Fol & 275 & 60 & eixo B (dobras monoclinais) & 0 & 5 & \\
\hline & & & Fol & 50 & 60 & & & & \\
\hline UM-625 & 6794337 & 531991 & Fol & 75 & 85 & & - & -1 & rocha calciossilicática? com Grt, Qtz, Pl..., e ocorre quartzito carbonático com cerca de $5 \mathrm{~m}$ de \\
\hline & & & Fol & 50 & 78 & $\mid \mathrm{Lm}$ & 328 & 20 & 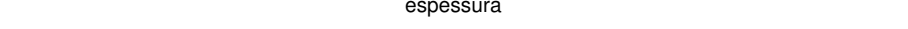 \\
\hline $\mathrm{UM}-626$ & 6794081 & 532736 & Fol & 50 & 65 & & & & \\
\hline & & & Fol (geral) & 275 & 62 & & & & \\
\hline & & & Fol & 142 & 82 & & & & seq. de intercalações métricas a decamétricas de mármores, calciossilicáticas (anfibolitos \\
\hline UM-650 & 6802649 & 540982 & Fol & 283 & 72 & & 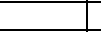 & & quartzosos) e xistos a Ms e Bt. Ocorre corpo de leucopegmatito com Turm e Ms dobrado junto \\
\hline & & & Fol & 292 & 80 & & & & com a seq. \\
\hline & & & PA & 306 & 55 & eixo B & 237 & 71 & \\
\hline
\end{tabular}




\begin{tabular}{|c|c|c|c|c|c|c|c|c|c|}
\hline Pontos & UTM-N & UTM-E & S-TIPO & S-DIR & S-DIP & L-TIPO & L-DIR & L-DIP & \multirow{6}{*}{$\begin{array}{l}\text { predominância de Chl-Bt xisto com vênulas qtz-feldsp, ocorrem bandas de Als(Ky....)-St...-Grt-ChI } \\
\text { Bt xisto }\end{array}$} \\
\hline \multirow{5}{*}{ UM-651 } & \multirow{5}{*}{6802826} & \multirow{5}{*}{541154} & Fol & 294 & 47 & Le (Qtz-Felds) & 280 & 46 & \\
\hline & & & Fol & 288 & 60 & & & & \\
\hline & & & Fol & 282 & 55 & & & & \\
\hline & & & Fol (flanco inf) & 285 & 66 & Lb (dobra aberta pós-S2) & 350 & 47 & \\
\hline & & & Fol (flanco sup) & 71 & 64 & & & & \\
\hline UM-652 & 6802918 & 541482 & Fol & 332 & 50 & Lb (cren) & 332 & 50 & \multirow{10}{*}{$\begin{array}{l}\text { seq dos xistos esverdeados e camadas métricas de mármore alaranjado e bandas submétricas } \\
\text { de parantibolitos. Ocorre corpo de leucopegmatito com Turm e Ms dobrado junto com a seq. }\end{array}$} \\
\hline \multirow{9}{*}{ UM-653 } & \multirow{9}{*}{6802238} & \multirow{9}{*}{540837} & Fol & 300 & 70 & & 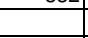 & & \\
\hline & & & Fol & 310 & 80 & & & & \\
\hline & & & \begin{tabular}{|l} 
Fol (flanco E) \\
\end{tabular} & 120 & 80 & & & & \\
\hline & & & Fol (flanco W) & 294 & 70 & eixo B! & 225 & 45 & \\
\hline & & & Fol (flanco W) & 290 & 65 & & & & \\
\hline & & & Fol (charneira) & 220 & 30 & eixo $B$ & 228 & 26 & \\
\hline & & & Fol & 300 & 38 & & 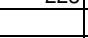 & & \\
\hline & & & Fol & 80 & 15 & eixo $B$ & 22 & 3 & \\
\hline & & & Fol & 102 & 38 & & & & \\
\hline \multirow{3}{*}{ UM-654 } & \multirow{3}{*}{6802136} & \multirow{3}{*}{540445} & \begin{tabular}{|c|c|c|} 
Fol \\
al
\end{tabular} & 286 & 86 & & & & \multirow{3}{*}{$\begin{array}{l}\text { Ms-Bt quartzito com Grt e Turm, intercalados por camadas de mármore associado com boudins } \\
\text { de anfibolito }\end{array}$} \\
\hline & & & Fol & 278 & 84 & & & & \\
\hline & & & Fol & 284 & 81 & $\operatorname{Lm}(\mathrm{Ms})$ & 357 & 55 & \\
\hline \multirow{3}{*}{ UM-655 } & \multirow{3}{*}{6802138} & \multirow{3}{*}{540327} & Fol & 280 & 75 & $\operatorname{Lm}(\mathrm{Ms})$ & 340 & 66 & \multirow{3}{*}{$\begin{array}{l}\text { Bt quartzitos e Ms-Bt xistos quartzosos com Grt, intercalados por camadas métricas de anfibolito } \\
\text { finamente foliado, ocorrem níveis pegmatíticos concordantes à foliação. Há grande quantidade } \\
\text { de veios pegmatíticos sin a tardi tectônicos e diques discordantes pós tectônico }\end{array}$} \\
\hline & & & Fol & 279 & 75 & & & & \\
\hline & & & Fol & 292 & 69 & $\operatorname{Lm}(\mathrm{Ms})$ & 352 & 54 & \\
\hline UM-656 & 6802099 & 540072 & & & & & & & $\begin{array}{l}\text { extenso corpo de granito e grande quantidade de veios graníto-pegmatíticos que cortam a seq } \\
\text { metassedimentar }\end{array}$ \\
\hline \multirow{2}{*}{ UM-657 } & & & Fol & 276 & 70 & & & & intercalaçōes de xisto quartzoso, anfibolitos finos e pegmatitos deformados. Há diques granito- \\
\hline & 6801932 & 539823 & Fol & 275 & 84 & & & & pegmatíticos tardios que cortam a seq de rochas metamórficas \\
\hline UM-658 & & 538950 & Fol & 270 & 57 & Lm (Amph) & 208 & $3 \quad 30$ & espesso pacote de rocha metamáfica (calciossilicática) intercalado com bandas de mármore, \\
\hline UIM-658 & $6801 / 32$ & 538950 & Fol & 270 & 65 & eixo $B$ & 230 & 50 & xisto quartzoso a Bt e Amph xisto \\
\hline & & & Fol & 308 & 67 & & & & \\
\hline & & & Fol & 280 & 55 & Le (Felds) & 207 & 20 & \\
\hline & & & Fol & 312 & 65 & Lm (Amph) & 218 & 3 & seq de gnaisses calciossilicáticos bandados, com bandas centimétricas esverdeadas e bandas \\
\hline UM-659 & 6808727 & 533533 & Fol & 312 & 70 & $\operatorname{Lm}(\mathrm{Amph})$ & 222 & & milimétricas félsicas e máficas. Ocorrem bandas graníticas róseas protomiloníticas de granulaçăa \\
\hline & & & Fol & 304 & 57 & Lm (Amph) & 222 & 5 & grossa, aparecem xistos quartzosos intercalado na seq bandada e há filōes de granito rosa que \\
\hline & & & Fol & 290 & 64 & $\mathrm{Lm}(\mathrm{Bt})$ & 18 & 20 & cortam toda a seq, assim como diques básicos \\
\hline & & & Fol & 338 & 65 & Lin (D) & 10 & 20 & \\
\hline & & & Fol & 145 & 74 & Le & 50 & 15 & \\
\hline & & & Fol & 136 & 75 & Le & 55 & 20 & \\
\hline UM-660 & 6808791 & 533824 & Fol & 140 & 72 & Le & 60 & 14 & Bt gnaisse milonítico com porfiroclastos de FK sigmoidais e bandas centimétricas \\
\hline & & & Fol & 148 & 78 & Le & & & \\
\hline & & & Fol & 139 & 78 & $\mathrm{Le}$ & 54 & 9 & \\
\hline & & & Fol & 138 & 85 & & & & \\
\hline & & & Fol & 308 & 86 & & & & \\
\hline & & & Fol & 142 & 77 & & & & boudins submétricos de rocha básica de aspecto maciço intercalados em granitos milonitizados \\
\hline UM-661 & 6808641 & 533961 & Fol & 124 & 80 & Le & 40 & 1 & róseos e Bt gnaisse milonítico. RETROECLOGITO... Grt-Cpx anfibolito! \\
\hline & & & Fol & 140 & 80 & Le & 38 & 2 & \\
\hline & & & & & & & & & \\
\hline & & & Fol & 275 & 65 & & & & \\
\hline UM-662 & 6808432 & 534270 & Fol & 265 & 75 & $\mathrm{Lm}(\mathrm{PI})$ & 348 & 5 & espessa camada ( 10-15m) de Grt anfibolito bandado. Boudins de rocha metabásica ocorrem \\
\hline & & & Fol & 282 & 79 & $\operatorname{Lm}(\mathrm{PI})$ & 9 & 915 & \\
\hline & & & Fol & 108 & 54 & & & & \\
\hline & & & Fol & 92 & 54 & Le & 148 & 34 & contato entre espessa camada de metamáfica com Grt, $\mathrm{Hbl}, \mathrm{Chl}$ ?, e seq de xistos e filitos \\
\hline & & & Fol & 94 & 44 & Le & 165 & 20 & prateados. Seq metapelítica possui boudins de anfibolito, filitos quartzosos prateados e Grt-St?- \\
\hline UM-663 & 6792641 & 536849 & Fol & 115 & 36 & Le & 172 & 16 & Bt xisto quartzoso prateado. Há intercalações métricas a submétricas de carbonato bandado e \\
\hline & & & Fol & 116 & 58 & $\mathrm{Lm}(\mathrm{Ms})$ & 200 & 9 & metamáficas. \\
\hline & & & Fol & 128 & 75 & $\mathrm{Lm}(\mathrm{Ms})$ & 210 & 28 & \\
\hline
\end{tabular}




\begin{tabular}{|c|c|c|c|c|c|c|c|c|c|}
\hline Pontos & UTM-N & UTM-E & S-TIPO & S-DIR & S-DIP & L-TIPO & L-DIR L L & L-DIP & Litotipos \\
\hline \multirow{3}{*}{ UM-664 } & \multirow{3}{*}{6792427} & \multirow{3}{*}{536985} & Fol & 272 & & Le & 185 & 40 & \\
\hline & & & Fol & 273 & 86 & Le & 185 & 37 & \multirow[t]{2}{*}{ bandas de rocha carbonática bandada fina intercalada nos xistos e níveis de rochas metamáficas } \\
\hline & & & Fol & 92 & 82 & Le & 182 & 20 & \\
\hline \multirow{3}{*}{ UM-665 } & \multirow{3}{*}{6792124} & \multirow{3}{*}{537024} & Fol & 84 & 75 & Le & 168 & 75 & \multirow{3}{*}{$\begin{array}{l}\text { intercalaçōes de St?-Grt-Bt-Chl-Ser xisto quartzoso, mármore laranja, metacarbonatos bandados } \\
\text { fino e Amph-Chl xisto-filito esverdeado. Seq de carbonatos e xistos esverdeados }\end{array}$} \\
\hline & & & & & & eixo B (dobras abertas) & 20 & 45 & \\
\hline & & & & & & eixo B (dobras abertas) & 55 & 80 & \\
\hline \multirow{3}{*}{ UM-666 } & \multirow{3}{*}{6791913} & \multirow{3}{*}{537247} & Fol & 95 & 75 & & & & \multirow{3}{*}{ metagabro com Grt } \\
\hline & & & Fol & 70 & 55 & & & & \\
\hline & & & Fol & 115 & 70 & Le (interrog) & 115 & 70 & \\
\hline \multirow{3}{*}{ UM-667 } & \multirow{3}{*}{6791919} & \multirow{3}{*}{537353} & Fol & 104 & 55 & Le (PI)!! & 82 & 51 & \multirow{3}{*}{$\begin{array}{l}\text { contato entre o pacote de anfibolito grosso (metagabro) e xistos-quartzitos. Intercalaçōes } \\
\text { centimétricas de Grt-(St-Ky?)-Bt-Ms quartzito e Bt-Ms xisto finamente foliado }\end{array}$} \\
\hline & & & Fol & 110 & 70 & Lb (cren1) & 193 & 17 & \\
\hline & & & $\mathrm{PA}$ & 40 & 75 & Lb (cren2) & 83 & 71 & \\
\hline \multirow{2}{*}{ UM-668 } & \multirow{2}{*}{6791958} & \multirow{2}{*}{537385} & Fol & 91 & 80 & & & & \multirow{2}{*}{ Grt-Bt-Chl xisto fino (ou Grt-Chl anfibolito?) e quartzitos impuros com Grt } \\
\hline & & & Fol & 90 & 75 & Le & 175 & 15 & \\
\hline UM-669 & 6792083 & 537456 & Fol & 80 & 75 & Le (mullion Qtz) & 168 & 2 & seq de xistos e quartzitos - St?-Grt-Chl-Bt-Ms xisto quartzoso \\
\hline UM-670 & 6792325 & 537233 & $\mid \begin{array}{lll}\mid \text { Fol } \\
\text { F-al }\end{array}$ & 296 & 32 & Lb (cren) & 232 & 10 & contato entre o pacote espesso de rocha metabásica e seq xisto-quartzítica \\
\hline UM-700 & 6794470 & 535131 & Fol & 330 & 18 & & & & alternância entre bandas carbonáticas espessas, calciossilicáticas e anfibolitos \\
\hline \multirow{7}{*}{ UM-701 } & \multirow{7}{*}{6794434} & & Fol (geral) & 135 & 70 & & & & \\
\hline & & & Fol & 65 & 63 & & & & \\
\hline & & & $\mathrm{PA}$ & 295 & 72 & eixo B & 240 & 81 & \\
\hline & & 533867 & $\mathrm{PA}$ & 298 & 77 & eixo B & 220 & 68 & intercalam carbonatos, calciossilicáticas, anfibolitos e Grt quartzito com Ms e Bt \\
\hline & & & PA & 285 & 60 & eixo B & 283 & 65 & \\
\hline & & & Cliv (PA) & 307 & 62 & & & & \\
\hline & & & & & & $\mathrm{Lb}$ & 260 & 61 & \\
\hline & & & Fol (banda/o) & 260 & 57 & & & & \\
\hline & & & Fol (banda/o) & 160 & 35 & & & & \\
\hline UM-702 & 6793349 & 531586 & Fol (banda/o) & 60 & 66 & & & & sequência de mármores. rocha acamadada, creme amarelado claro com variaçōpes de níveis \\
\hline & & & Fol & 43 & 68 & Le & 135 & 16 & grossos e finos mais bandados, e ocorrem boudins de metagabro coronítico \\
\hline & & & PA & 135 & 82 & eixo B & 225 & 60 & \\
\hline & & & Fol & 165 & 73 & & & & \\
\hline UM-703 & 6792888 & 532263 & Fol & 348 & 74 & & & & anfibolito muito foliado com variaçōes de granulometria \\
\hline UM-704 & 6801093 & 538437 & Fol & 265 & 79 & $\mathrm{Lm}$ & 360 & 9 & sequência de xistos micáceos bandas carbonáticas e anfibolitos finos intercalados \\
\hline & & & & 268 & 72 & & & & 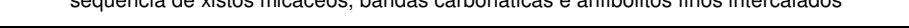 \\
\hline UM-800 & 6777400 & 525973 & SO & $\frac{194}{180}$ & $\frac{37}{39}$ & & & & arenitos feldspáticos avermelhados \\
\hline & & & $\frac{\text { So }}{\text { So }}$ & $\frac{180}{240}$ & $\frac{39}{25}$ & & & & \\
\hline UM-801 & 6777617 & 526297 & So & $\frac{240}{242}$ & $\frac{20}{30}$ & & & - & arenitos arcoseanos de coloração clara e arenitos conglomeráticos mal selecionados de \\
\hline & & & falha inversa & 235 & 52 & & & & coloração escura \\
\hline & & & Fol (milon) & 265 & 65 & estria & 180 & 20 & \\
\hline & & & Fol (milon) & 250 & 90 & estria & 175 & 25 & \\
\hline UM-802 & & & Fol (milon) & 265 & 67 & mullion Qtz & 230 & 62 & \\
\hline & 6777798 & 526426 & Fol (milon) & 270 & 65 & Lm (Felds) & 250 & 61 & milonitos e protomilonitos quartzosos com feldspato e micas (Bt+Ms) \\
\hline & & & Fol (milon) & 260 & 80 & estria & 165 & 18 & \\
\hline & & & PA (cren) & 30 & \begin{tabular}{l|l|}
43 \\
\end{tabular} & & & & \\
\hline
\end{tabular}




\begin{tabular}{|c|c|c|c|c|c|c|c|c|c|}
\hline Pontos & UTM-N & UTM-E & S-TIPO & S-DIR & S-DIP & L-TIPO & L-DIR & \begin{tabular}{|l|l|l|} 
L-DIP \\
\end{tabular} & \multirow{20}{*}{$\begin{array}{l}\text { Bt-Hbl gnaisse s tonalíticos/granodioríticos predominam com leucossomas claros com Qtz } \\
\text { azulado. Veios sienograníticos cortam os gnaisses e apresentam-se deformados. Ocorrem } \\
\text { rochas básicas intrusivas tardias }\end{array}$} \\
\hline \multirow{19}{*}{ UM-803 } & \multirow{19}{*}{6777831} & \multirow{19}{*}{526667} & Fol (banda/o) & 103 & 62 & & & & \\
\hline & & & \begin{tabular}{|l|} 
Fol (banda/o) \\
\end{tabular} & 105 & 78 & & & & \\
\hline & & & Fol (banda/o) & 90 & 56 & & & & \\
\hline & & & Fol (protomilon) & 205 & 55 & Le & 105 & 10 & \\
\hline & & & Fol (banda/o) & 112 & 45 & & & & \\
\hline & & & Fol (banda/o) & 115 & 50 & & & & \\
\hline & & & \begin{tabular}{|l} 
Fol (banda/o) \\
\end{tabular} & 115 & 60 & & & & \\
\hline & & & & & & estria & 90 & 0 & \\
\hline & & & dique milonitico & 210 & 80 & estria & 120 & 0 & \\
\hline & & & filẫo granítico & 30 & 78 & & & & \\
\hline & & & dique & 223 & 75 & & & & \\
\hline & & & dique & 220 & 60 & & & & \\
\hline & & & falha inversa & 30 & 75 & estria & 125 & 18 & \\
\hline & & & \begin{tabular}{|l|l|} 
Fol \\
\end{tabular} & 15 & 65 & & & & \\
\hline & & & falha & 240 & 54 & & & & \\
\hline & & & Fol & 270 & 78 & & & & \\
\hline & & & dique (// falha) & 30 & 65 & & & & \\
\hline & & & Fol & 50 & 43 & & & & \\
\hline & & & falha & 56 & 51 & & & & \\
\hline \multirow{18}{*}{ UM-804 } & \multirow{18}{*}{6778141} & \multirow{18}{*}{526622} & Fol (banda/o) & 40 & 53 & Le (Bt) & 65 & 50 & \multirow{18}{*}{$\begin{array}{l}\text { Bt gnaisse bandado fino-médio com bandas milimétricas a centimétricas tabulares a lenticulares } \\
\text { de sienogranitos. Bandas sienograníticas apresentam-se frequentemente dobradas em dobras } \\
\text { intrafoliais }\end{array}$} \\
\hline & & & \begin{tabular}{|l} 
Fol (banda/o) \\
\end{tabular} & 30 & 60 & Le (Bt) & 58 & 55 & \\
\hline & & & \begin{tabular}{|l} 
Fol (banda/o) \\
\end{tabular} & 40 & 56 & & & & \\
\hline & & & \begin{tabular}{|l} 
Fol (banda/o) \\
\end{tabular} & 35 & 50 & Lestria & 110 & 17 & \\
\hline & & & \begin{tabular}{|l|l} 
Fol (banda/o) \\
\end{tabular} & 30 & 82 & & & & \\
\hline & & & \begin{tabular}{|l} 
Fol (banda/o) \\
\end{tabular} & 343 & 35 & & & & \\
\hline & & & Fol (banda/o) & \begin{tabular}{c|}
65 \\
\end{tabular} & 70 & Le & 83 & 68 & \\
\hline & & & Fol (banda/o) & 45 & 55 & & & & \\
\hline & & & Fol (banda/o) & 34 & 58 & Le & 63 & 54 & \\
\hline & & & Falha inversa & 360 & 85 & & & & \\
\hline & & & & & & eixo B (dobra de arraste) & 290 & 38 & \\
\hline & & & Fol & 360 & 46 & & & & \\
\hline & & & Fol (banda/o) & 40 & 52 & Le & 290 & 42 & \\
\hline & & & \begin{tabular}{|l|l|l} 
Fol (banda/o) \\
\end{tabular} & 55 & 72 & & & & \\
\hline & & & \begin{tabular}{|l|l|l} 
Fol (banda/o) \\
\end{tabular} & 360 & 35 & & & & \\
\hline & & & Fol (banda/o) & 35 & 48 & & & & \\
\hline & & & & & & eixo B (dobras abertas) & 270 & 10 & \\
\hline & & & & & & eixo B (dobras abertas) & 80 & 10 & \\
\hline \multirow{5}{*}{ UM-805 } & \multirow{5}{*}{6778250} & \multirow{5}{*}{526781} & Fol (banda/o) & 20 & 50 & Lb & 73 & 20 & \multirow{5}{*}{ predominam Bt gnaisses finos, melanocráticos com Grt e Amph localmente } \\
\hline & & & & 10 & 85 & Le & 95 & 55 & \\
\hline & & & Fol (banda/o) & 17 & 37 & & & & \\
\hline & & & Fol (banda/o) & 340 & 49 & & & & \\
\hline & & & PA (cren) & 169 & 53 & & & & \\
\hline \multirow{13}{*}{ UM-806 } & \multirow{13}{*}{6778427} & \multirow{13}{*}{526830} & Fol (banda/o) & 45 & 76 & Le (felds) & 95 & 65 & \\
\hline & & & Fol (banda/o) & 40 & 80 & Lb (microcrenulação) & 123 & 25 & \\
\hline & & & Fol (milon) & 62 & 78 & Le (Bt+mulion) & 94 & 65 & \\
\hline & & & Fol (milon) & 60 & 70 & Le (Bt+mulion) & 93 & 60 & \\
\hline & & & Fol (milon) & 76 & 65 & Le (Bt+mulion) & 90 & 65 & \\
\hline & & & Fol (milon) & 35 & 85 & & & & \\
\hline & & & Fol (milon) & 40 & 80 & Le & 95 & 65 & \\
\hline & & & Fol (milon) & 10 & 80 & Le & 80 & 50 & Bt gnaisse granítico com boudins de rocha máfica. Há estruturas de pares $\mathrm{S} / \mathrm{C}$ e porfiroclastos \\
\hline & & & Fol (milon) & 25 & 80 & Le & 93 & 60 & feldspáticos. Há Grt no mesossoma e leucossoma e melanossoma rico em Amph \\
\hline & & & Fol (milon) & 45 & 76 & Lmin (Bt/Amph) & 108 & 47 & \\
\hline & & & Fol (milon) & 40 & 85 & Lb & 123 & 25 & \\
\hline & & & & 40 & 86 & Le & 110 & 40 & \\
\hline & & & faixa milonitica ruptil/ductil & 27 & 75 & & & & \\
\hline & & & Fol (milon) & 76 & 65 & Le (mullion Qtz) & 90 & 65 & \\
\hline UM-806A & 6778507 & 526785 & Fol (milon) & 60 & 70 & Le (mullion Qtz) & 93 & 60 & \\
\hline & & & Fol (milon) & 62 & 78 & Le (mullion Qtz) & 94 & 65 & \\
\hline
\end{tabular}




\begin{tabular}{|c|c|c|c|c|c|c|c|c|c|}
\hline Pontos & UTM-N & UTM-E & S-TIPO & S-DIR & S-DIP & L-TIPO & L-DIR & L-DIP & \multirow{4}{*}{$\begin{array}{c}\text { Litotipos } \\
\text { mármores silicificados e Grt-mica-Qtz xisto }\end{array}$} \\
\hline \multirow{3}{*}{ UM-807 } & Orimerv & 0 & so & 287 & 20 & eixo B (dobras fechadas) & 345 & 85 & \\
\hline & 6778511 & 526790 & Fol (milon) & 55 & 62 & Le & 270 & 58 & \\
\hline & & & Fol & 40 & 75 & & & & \\
\hline \multirow{3}{*}{ UM-808 } & & & Fol & 8 & 42 & $\operatorname{Lm}(\mathrm{Bt})$ & 55 & 40 & \multirow{3}{*}{ Bt gnaisse fortemente milonítico,com Hbl gnaisse e anfibolitos intercalados } \\
\hline & 6778736 & 526906 & Fol & 50 & 30 & Le (mullion) & 52 & 30 & \\
\hline & & & Fol & 22 & 40 & & 50 & 40 & \\
\hline \multirow{4}{*}{ UM-809 } & & & Fol & 350 & 42 & & & & \multirow{4}{*}{ Bt gnaisses e anfibolitos } \\
\hline & & 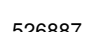 & Fol & 353 & 56 & Le (Qtz) & 40 & 30 & \\
\hline & 6778774 & 526887 & Fol & 324 & 44 & & & & \\
\hline & & & Fol & $\frac{524}{20}$ & 47 & Lb & 43 & 45 & \\
\hline \multirow{2}{*}{ UM-810 } & 6778826 & 526848 & Fol & 20 & 65 & Lmulion & 77 & 50 & \multirow{2}{*}{ anfibolitos intercalados em gnaisses biotíticos com Grt, e níveis leucossomáticos com Grt } \\
\hline & 6778826 & 526848 & Fol & 30 & 58 & & 50 & 50 & \\
\hline \multirow{5}{*}{ UM-811 } & & & Fol & 5 & 89 & Le (felds) & 95 & 66 & \multirow{5}{*}{ Bt gnaisses com initercalações de anfibolitos e metagabros foliados } \\
\hline & & & Fol & 150 & 80 & & & & \\
\hline & 6778875 & 526788 & Fol & 155 & 70 & & & & \\
\hline & & & Fol & 165 & 67 & Le (felds) & 280 & 45 & \\
\hline & & & Xistosi// obliqua & 27 & 53 & Lint & 60 & 45 & \\
\hline \multirow{7}{*}{ UM-812 } & & & Fol (banda/o) Sn-1 & 308 & 38 & & & & \multirow{7}{*}{ Bt gnaisses graníticos } \\
\hline & & & Fol (banda/o) Sn-1 & 250 & 20 & & & & \\
\hline & & & Fol (banda/o) Sn-1 & 280 & 20 & Lb & 355 & 9 & \\
\hline & 6778923 & 526713 & Fol (banda/o) Sn-1 & 285 & 19 & & 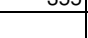 & & \\
\hline & & & Clivagem & 0 & 85 & & & & \\
\hline & & & Clivagem & 340 & 80 & & & & \\
\hline & & & Clivagem & 75 & 90 & & & & \\
\hline \multirow{7}{*}{ UM-813 } & & & Fol (banda/o) Sn-1 & 318 & 28 & & & & \multirow{7}{*}{ Bt gnaisse de composição Qtz sienítica ou (Bt quartzo sienito foliado) } \\
\hline & & & Fol (banda/o) Sn-1 & 219 & 18 & & & & \\
\hline & & & Fol (banda/o) Sn-1 & 220 & 24 & & & & \\
\hline & 6778950 & 526638 & Fol (banda/o) Sn-1 & 340 & 38 & & & & \\
\hline & & & Fol (banda/o) Sn-1 & 308 & 17 & & & & \\
\hline & & & Fol (protomilon) & 230 & 60 & & & & \\
\hline & & & Fol (protomilon) & 220 & 75 & & & & \\
\hline \multirow{11}{*}{ UM-814 } & & & So/clivagem ardosiana & $\frac{c c 5}{105}$ & 53 & & & & \multirow{11}{*}{$\begin{array}{l}\text { intercalaçōes métricas a decamétricas de mármores alaranjados e filitos/ardósias vermelho } \\
\text { prateadas. Mármores silicificados e minerais fibrorradiados nos filitos (metamorfismo de } \\
\text { contato?) }\end{array}$} \\
\hline & & & So/dlivagem ardosiana & 139 & 74 & & & & \\
\hline & & & So/clivagem ardosiana & 126 & 80 & & & & \\
\hline & & & So/clivagem ardosiana & 314 & 82 & & & & \\
\hline & & & So/clivagem ardosiana & 130 & 90 & & & & \\
\hline & 6798896 & 521765 & So/clivagem ardosiana & 90 & 50 & & & & \\
\hline & 0700000 & 207100 & \begin{tabular}{|l} 
Cliv. Espaçada \\
\end{tabular} & 50 & 43 & & & & \\
\hline & & & So/dlivagem ardosiana & 123 & 82 & & & & \\
\hline & & & & 177 & 70 & eixo $B$ & 55 & 30 & \\
\hline & & & & 163 & 70 & eixo $B$ & 145 & 80 & \\
\hline & & & & & & eixo $B$ & 55 & 60 & \\
\hline & & & Fol (milon) & 90 & 26 & Le (Qtz) & 1 & 4 & \\
\hline & & & & 218 & 60 & eixo B & 135 & 23 & \\
\hline & & & $\begin{array}{l}\text { Fol (milon) } \\
\end{array}$ & 72 & 34 & Le (Qtz) & 358 & 8 & \\
\hline & & & $\begin{array}{l}\text { Fol (milon) } \\
\text { Fon }\end{array}$ & 64 & 24 & $\operatorname{Lm}(\mathrm{Bt})$ & 356 & 2 & \\
\hline & & & \begin{tabular}{|l} 
Fol (milon) \\
\end{tabular} & 68 & 23 & $\mathrm{Lb}$ (cren) & 66 & 22 & \\
\hline UM-815 & 6802594 & 527186 & $\begin{array}{l}\text { Fol (milon) } \\
\end{array}$ & 63 & 45 & & 135 & 18 & 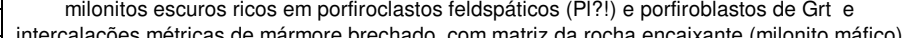 \\
\hline & & & & & & Le & 355 & 20 & intercalações métricas de mármore brechado, com matriz da rocha encaixante (milonito máfico) \\
\hline & & & & & & Le & 110 & 30 & \\
\hline & & & Fol (milon) & 80 & 58 & Le & 15 & 52 & \\
\hline & & & Fol (milon) & 55 & 45 & Le & 20 & 35 & \\
\hline & & & Fol (milon) & $\frac{50}{116}$ & 22 & Le (Qtz) & $\frac{20}{159}$ & $\frac{35}{14}$ & \\
\hline & & & Fol (milon) & 80 & 50 & Le & 355 & 5 & \\
\hline UM-816 & 6802565 & 527118 & Fol (milon) & 65 & 52 & Le & 5 & 36 & milonitos metapelíticos com Grt e Bt e níveis de mármores brechados \\
\hline & & & Fol (milon) & 67 & 34 & & 326 & 4 & \\
\hline
\end{tabular}




\begin{tabular}{|c|c|c|c|c|c|c|c|c|c|}
\hline $\begin{array}{l}\text { Pontos } \\
\end{array}$ & UTM-N & UTM-E & S-TIPO & S-DIR & S-DIP & L-TIPO & L-DIR & -DIP & Litotipos \\
\hline \multirow{8}{*}{ UM-817 } & \multirow{8}{*}{6802544} & \multirow{8}{*}{526941} & Fol (milon) & 90 & 23 & Le & 174 & 4 & \multirow{8}{*}{$\begin{array}{l}\text { milonitos biotíticos com intercalações decimétricas a métricas de mármores brechados. Há } \\
\text { dobras intrafoliais definidas por níveis de mármores }\end{array}$} \\
\hline & & & & 12 & $71 \mid$ & eixo B (dobra intrafolial) & 150 & 56 & \\
\hline & & & & & & eixo B (dobra intrafolial) & 165 & 40 & \\
\hline & & & Fol (milon - S) par S/C & 94 & 72 & & & & \\
\hline & & & Fol (milon - C) par S/C & 135 & 60 & & & & \\
\hline & & & Fol (milon) & 80 & 35 & Le & 150 & 18 & \\
\hline & & & Fol (milon) & 82 & 46 & Le & 145 & 16 & \\
\hline & & & Fol (milon) & 120 & 45 & Le (mullion) & 175 & 27. & \\
\hline \multirow{3}{*}{ UM-818 } & \multirow{3}{*}{6802544} & \multirow{3}{*}{526879} & Fol & 72 & 50 & & & & \multirow{3}{*}{ intercalaçōes/boudins de Grt anfibolitos (com pouco Pl e Cpx??) em milonito biotíitico com Grt } \\
\hline & & & Fol & 105 & 62 & & & & \\
\hline & & & Fol & 80 & 80 & $\operatorname{Lm}(\mathrm{Bt})$ & 145 & 32 & \\
\hline \multirow{8}{*}{ UM-819 } & \multirow{8}{*}{6802953} & \multirow{8}{*}{525625} & Fol (milon) & 290 & 48 & $\operatorname{Lm}(\mathrm{Bt})$ & 225 & 28 & \multirow{8}{*}{$\begin{array}{l}\text { Grt-Bt paragnaisses miloníticos com Sill e boudins de metabásicas e níveis de comp. tonalítica } \\
\text { rica em porfiroclastos. Há dobras assimétricas, inclinadas e fechadas, vergentes para SE }\end{array}$} \\
\hline & & & Fol (milon) & 290 & 66 & & & & \\
\hline & & & & & & Lb (D3 assim verg p/ SE) & 224 & 50 & \\
\hline & & & & & & Lb (D3 assim verg p/ SE) & 238 & 54 & \\
\hline & & & & & & Lb (D3 assim verg p/SE) & 220 & 49 & \\
\hline & & & PA (D3) & 280 & 83 & eixo B (D3) & 193 & 38 & \\
\hline & & & PA (D3) & 305 & 85 & & & & \\
\hline & & & Clivagem PA (S3) & 275 & 74 & & & & \\
\hline \multirow{4}{*}{ UM-820 } & \multirow{4}{*}{6802476} & \multirow{4}{*}{527616} & Fol & 190 & 18 & & & & \multirow{4}{*}{$\begin{array}{l}\text { Grt-Bt-Qtz metadiorito/gabro?, foliado com enclaves de anfibolito. Há diques de Bt } \\
\text { leucomonzogranito dobrado em dobras isoclinais fechadas com fol PA }\end{array}$} \\
\hline & & & Fol (banda/o) & 257 & 70 & & & & \\
\hline & & & Fol (banda/o) & 70 & 70 & & & & \\
\hline & & & Fol (banda/o) & 250 & 65 & & & & \\
\hline \multirow{2}{*}{ UM-821 } & \multirow{2}{*}{6802485} & \multirow{2}{*}{527677} & $\frac{P A \text { (dobras intrafoliais) }}{\text { Fol }}$ & $\frac{108}{55}$ & $\frac{53}{58}$ & eixo B & 180 & 25 & \multirow{2}{*}{$\begin{array}{l}\text { Grt metagabro foliado com boudins de rocha ultramáfica com Grt (piroxenito ou anfibolitito?) e } \\
\text { dobras intrafoliais definidas por bandas throndjemíticas }\end{array}$} \\
\hline & & & Fol & $\begin{array}{l}55 \\
65\end{array}$ & 58 & & & & \\
\hline \multirow{7}{*}{ UM-822 } & \multirow{7}{*}{6802506} & & Fol (banda/o ígneo) & 250 & 86 & & & & \\
\hline & & & Fol (banda/o ígneo) & 102 & 55 & & & & \\
\hline & & & Fol (banda/o ígneo) & 200 & 43 & & & & metagabro porfiroblástico bandado (banda/o ígneo!?) com Grt e fenocristais(?) de $\mathrm{Pl}$, rico em \\
\hline & & 527776 & Fol (banda/o ígneo) & 60 & 62 & & & & enclaves máficos (xenólitos?). Banda/o ígneo (?!!!) apresenta-se dobrado, em dobra abertas de \\
\hline & & & Fol (banda/o ígneo) & 240 & 61 & & & & \\
\hline & & & Fol (banda/o ígneo) & 220 & 45 & & & & \\
\hline & & & Fol (banda/o ígneo) & 240 & 50 & & & & \\
\hline & & & Fol & 115 & 50 & Lm (felds) & 50 & 22 & \\
\hline & & & Fol & 114 & 62 & $\operatorname{Lm}(\mathrm{Bt})$ & 196 & 4 & deformados. Contato entre unidade de milontios félsicos e bandas máficas (topo) e metagabro \\
\hline UM-823A & 6802566 & 527884 & PA & 110 & 61 & Lb & 205 & 2 & com Grt (base) e foliacão milonítica apresenta-se dobrada, em dobras inclinadas e fechadas \\
\hline & & & & & & Lm (felds) & 158 & 15 & 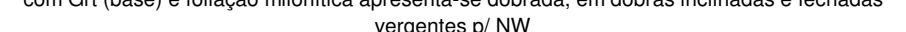 \\
\hline & & & PA & 105 & 64 [! & Lb & 190 & 10 & \\
\hline & & & PA & 95 & 65 & $\mathrm{Lb}$ & 175 & 45 & \\
\hline & & & & & & Lb & 130 & 35 & gnaisse milonítico cinza escuro, fino com porfiroclastos de feldspato branco, lâminas finas de \\
\hline UM-823B & 6802565 & 527904 & PA & 110 & $80 \mid$ & $\frac{\mathrm{Lb}}{\mathrm{L}}$ & 33 & 45 & gnaisse milonítico cinza claro, bandado. Bandas de granito sieníticos rosados de 0,5 a $2 \mathrm{~cm}$ de \\
\hline & 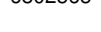 & - & PA & 108 & 75 & Lb & 40 & 70 & espessura ocorrem, plasticamente dobrados. Vergência oeste do dobramento desarmônico e em \\
\hline & & & & & & $\mathrm{Lb}$ & 105 & 45 & bainha com injeção de leucossoma granítico rosado no plano-axial das pequenas dobras \\
\hline & & & PA & 90 & $40 \mid$ & Lb & 100 & $30 \mid$ & \\
\hline
\end{tabular}

